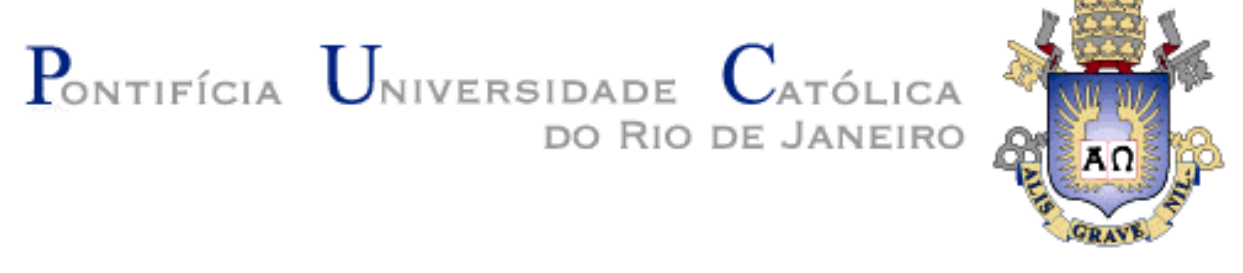

Bruna Santana Aucar

A publicidade no Brasil: agências, poderes e modos de
trabalho (1914-2014)

Tese DE Doutorado

Tese de Doutorado apresentada ao Programa de Pós-Graduação em Comunicação Social da PUC-Rio como requisito parcial para a obtenção do título de Doutor em Comunicação Social.

Orientador: Prof. Everardo Pereira Guimarães Rocha

Volume I

Rio de Janeiro

Abril de 2016 


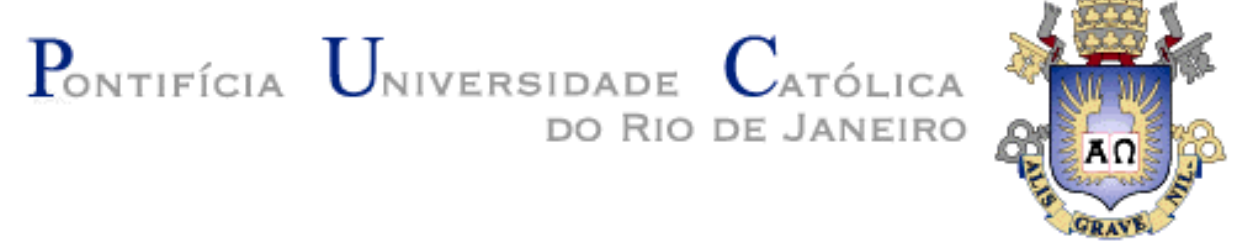

Bruna Santana Aucar

\section{A publicidade no Brasil: agências, poderes e modos de trabalho (1914-2014)}

Tese apresentada como requisito parcial para obtenção do grau de Doutor pelo Programa de Pós-graduação em Comunicação Social da PUC-Rio. Aprovada pela Comissão Examinadora abaixo assinada.

Prof $^{0}$. Everardo Pereira Guimarães Rocha

Orientador

Departamento de Comunicação Social - PUC-Rio

Prof. a Claudia da Silva Pereira Departamento de Comunicação Social - PUC-Rio

Prof $^{0}$. Miguel Serpa Pereira

Departamento de Comunicação Social - PUC-Rio

Prof $^{0}$. João Batista de Macedo Freire Filho

Universidade Federal do Rio de Janeiro

Prof $^{0}$. Muniz Sodré de Araújo Cabral Universidade Federal do Rio de Janeiro

Prof.a Ligia Campos de Cerqueira Lana

Departamento de Comunicação Social - PUC-Rio

Prof.a Mônica Herz

Vice - Decana de Pós-graduação do CCS - PUC-Rio

Rio de Janeiro, 13 de abril de 2016 
Todos os direitos reservados. É proibida a reprodução total ou parcial do trabalho sem autorização da universidade, da autora e do orientador.

\section{Bruna Santana Aucar}

Bruna aucar é professora do Departamento de Comunicação Social da PUC-Rio e editora de Projetos Especiais do Comunicar/PUC-Rio. É formada em jornalismo pela PUC-Rio e possui o mestrado em Comunicação Social pela mesma instituição. Atua na área da Comunicação, com ênfase nos seguintes temas: relações entre cultura e consumo: representações sociais da Cultura de Massa e história da publicidade e da televisão no Brasil.

Ficha Catalográfica

Aucar, Bruna Santana

A publicidade no Brasil : agências, poderes e modos de trabalho (1914 - 2014) / Bruna Santana Aucar ; orientador: Everardo Pereira Guimarães Rocha. 2016.

2 v. : il. ; $30 \mathrm{~cm}$

Tese (doutorado)-Pontifícia Universidade Católica do Rio de Janeiro, Departamento de Comunicação Social, 2016.

Inclui bibliografia

1. Comunicação Social - Teses. 2. Agências de publicidade. 3. Consumo. 4. Teoria da ação coletiva. 5. Howard Becker. 6. Etnografia. I. Rocha, Everardo Pereira Guimarães. II. Pontifícia Universidade Católica do Rio de Janeiro. Departamento de Comunicação Social. III. Título.

CDD: 302.23 
A história é a crônica da palavra. Moisés, no deserto; Demóstenes, nas guerras helênicas; Cristo, nas sinagogas da Galileia; Huss, no púlpito cristão; Mirabeau, na tribuna republicana: todas essas bocas eloquentes, todas essas cabeças salientes do passado, não são senão o fiat multiplicado levantado em todas as confusões da humanidade.

Machado de Assis 


\section{Agradecimentos}

Ao meu mestre e orientador, professor Everardo Rocha, pela grande parceria, incentivo e ajuda na realização deste e de tantos outros trabalhos. Também agradeço a generosidade, o carinho e orientações imprescindíveis ao longo de todo o meu percurso acadêmico.

Ao professor Cesar Romero Jacob, pela compreensão e apoio durante todo este período de doutorado e também em minha trajetória profissional.

Ao professor Miguel Pereira, pelo exemplo de vida, contribuições acadêmicas e oratória inspiradora.

À professora Angeluccia Habert, pela motivação profissional e sensibilidade na condução do Departamento de Comunicação Social.

Aos professores das disciplinas que tive o privilégio de cursar durante o doutorado.

Aos professores Claudia Pereira e João Freire Filho, pelas valiosas observações feitas durante a banca de qualificação, que serviram de estímulo e direção para que a pesquisa fosse concluída.

Aos professores Claudia Pereira, João Freire Filho, Miguel Pereira e Muniz Sodré, pela gentileza e prontidão em aceitar o convite para participar da banca de avaliação desta tese.

Aos professores e companheiros de trabalho do Portal PUC-Rio Digital, Alexandre Carauta, Celio Campos, Claudia Brütt, Cristina Matos, Ernani Ferraz, Gustavo Chataignier, Itala Maduell, Leticia Hees, Mauro Silveira e Rafael Rusak.

Aos meus colegas de doutorado, especialmente ao Felipe Gomberg, Marina Frid e William Corbo, pelas trocas de ideias e afetos.

Aos professores, funcionários e amigos do Departamento de Comunicação Social da PUC-Rio, especialmente à secretária do programa de pós-graduação em Comunicação Social da PUC-Rio, Marise Lira.

Às pesquisas desenvolvidas no Programa de Estudos em Comunicação e Consumo da PUC-Rio, coordenadas pelos professores Everardo Rocha e Cláudia Pereira.

À Vice-Reitoria para Assuntos Acadêmicos e ao Departamento de Comunicação Social da PUC-Rio, pela bolsa de doutorado. 
Aos meus pais, Tania e William, e à minha irmã, Rafaela, pelo incentivo e esforço para minha formação pessoal e profissional.

Ao Daniel, pelo apoio de sempre e pelo suporte emocional que me permitiu superar todas as dificuldades.

E, principalmente, ao meu querido filho Pedro, que mesmo antes de nascer já traz a esperança de um mundo com mais amor e tolerância. 


\section{Resumo}

Aucar, Bruna Santana; Rocha, Everardo Pereira Guimarães. A publicidade no Brasil: agências, poderes e modos de trabalho (1914 - 2014). Rio de Janeiro, 2016. 333p. Tese de doutorado - Departamento de Comunicação Social, Pontifícia Universidade Católica do Rio de Janeiro.

Esta tese realiza um estudo da história e do desenvolvimento das agências de propaganda do Brasil, a fim de compreender os principais movimentos do campo da publicidade no país ao longo de cem anos. Parte-se da premissa de que a agência é a organização responsável por traçar as condições de existência do setor da publicidade e do aparecimento social do anúncio, como resultado e expressão de tipos de interação social e ação coletiva. O marco cronológico é fixado a partir da fundação da Eclética, em 1914, a primeira empresa que elabora uma disposição profissionalizante e coopera para a formação de um segmento profissional, até então inexistente. A pesquisa procura mapear o curso das agências, suas conexões com as transformações histórico-culturais, realçando o desenvolvimento empresarial para discutir o peso do discurso publicitário na constituição dos códigos culturais. O foco recai no exame dos agentes sociais e suas ações, como partes determinantes da produção do conhecimento e da elaboração das identidades culturais em um determinado sistema social. Através da pesquisa bibliográfica e aproximação da rotina produtiva da publicidade, é possível perceber a importância da atuação conjunta de identidades para a viabilidade do trabalho. Neste sentido, a teoria da ação coletiva de Howard Becker ancora a reflexão sobre as identidades culturais dos sujeitos que produzem os anúncios dentro de uma agência de propaganda e suas formas de operação, elaboradas, historicamente, para a produção deste dispositivo de comunicação. $\mathrm{O}$ quadro teórico adotado também enfatiza a perspectiva cultural da publicidade e trabalhos que destacam a preponderância do simbólico na construção dos seus significados públicos. Além da conjuntura interna das empresas de propaganda, o estudo também pondera, de forma mais ampla, a publicidade como uma narrativa central na sociedade moderno-contemporânea, uma vez que ela produz e faz circular temas que impactam subjetividades e oferecem componentes para o 
estabelecimento de signos e práticas que nos definem como uma sociedade de consumo.

\section{Palavras-chave}

agências de publicidade; consumo; Teoria da Ação Coletiva; Howard Becker; Etnografia. 


\section{Abstract}

Aucar, Bruna Santana; Rocha, Everardo Pereira Guimarães. (Advisor) Advertising in Brazil: advertising agencies, power relations and work methods (1914-2014). Rio de Janeiro, 2016. 333p. Doctoral Thesis Departamento de Comunicação Social, Pontifícia Universidade Católica do Rio de Janeiro.

This dissertation provides an interpretative analysis on advertising agencies in Brazil in order to broadly examine the main movements in the field of advertising during the past one hundred years. We have relied on the assumption that the agency is the ownership that establishes conditions for the advertising sector's recognition as well as the social emergence of the ad, as an outcome and expression of social interaction and collective action types. The chronological framework is set as of the establishment of Eclética, in 1914, the first organization that devises a professional approach and sets the capacity building of a yet unknown professional segment. The survey pursues a constant on-going mapping of the agencies, the paths, and linkages with historical-cultural transformations, enhancing the entrepreneurial development in order to discuss the burden of the advertising speech vis-a-vis the cultural code heritage. The core focus is on the consideration of the social players and their actions as inherent part of the production of knowledge and issuance of cultural identities in a specific social system. By means of a bibliographic intersection with the productive routine of advertising, have endeavored to reach the final result of a joint performance of identities which crossing is of the utmost importance for its feasibility. Furthermore, Howard Becker's collective action theory anchors a profound reflection of the cultural identities of the subjects that convey the ads in an advertising agency, inasmuch as its ways of performance, historically produced for this communication device. The theoretical framework that has been considered, highlights as well, the cultural perspective of advertising and papers that enhance the prominence of symbolism when establishing cultural meanings. Besides the internal environment of the advertising organization, this survey contemplates, in a broader sense, advertising as a central narrative of modern 
contemporary culture inasmuch as it produces and circles issues that impact subjectivities and convey components to establish signs and practices that define us as a Consumption Society.

\section{Keywords}

advertising agencies; consumption; collective action; Becker; ethnography. 


\section{Sumário}

Introdução

1. Consumo, publicidade e pesquisa acadêmica

2. Publicidade - uma atividade do nosso tempo

2.1. Anúncio publicitário: sentidos e interpretações

49

2.2. Transformações do novo século

63

2.3. Novas perspectivas sociais e políticas

69

2.4. O sistema de classificação publicitário

77

3. A publicidade como ação coletiva 95

3.1. Representações culturais do publicitário 105

3.2. A agência em ação: estrutura e funcionamento 115

3.3. Redes de interação das agências

4. As Agências Pioneiras - identidade e profissionalização 135

4.1. A agência Eclética e a inauguração da era da propaganda 139 no país

4.2. Efeitos da Primeira Guerra Mundial

4.3. A chegada da indústria norte-americana 165

4.4. O triunfo das agências 192

5. A consolidação do campo publicitário 213

5.1. A ênfase na criatividade 221

5.2. A televisão chega à propaganda 235

5.3. O peso de um Leão de Ouro 244

6. O impacto da internet e o futuro da propaganda 257

6.1. Incertezas econômicas 262

6.2. Grandes fusões 272

6.3. On-line/Off-line: novos caminhos da produção de anúncios 282

7. Considerações finais e perspectivas de pesquisas futuras 300

8. Referências bibliográficas 


\section{Introdução}

O objetivo desta tese é realizar uma reflexão sobre o campo da publicidade $^{1}$ no Brasil, através da organização do trabalho empresarial e da trajetória das principais agências de propaganda. A agência foi a instância responsável pelos arranjos profissionais e pelo reconhecimento público que deram lugar ao que chamamos de publicidade no mundo moderno-contemporâneo. Assim, a pesquisa abrange um arco temporal de 100 anos, que tem início em 1914 com o surgimento da Eclética, a primeira empresa que estrutura um modelo de negócios para a propaganda no país. O intuito é destacar o aprimoramento das técnicas, as alternativas profissionais no processo de estabilização do segmento e as formas pelas quais a narrativa publicitária se consolida como eixo central, tanto na estrutura midiática, quanto em nosso imaginário.

Neste sentido, o estudo busca pensar a publicidade a partir do conjunto de instituições, identidades e pessoas que produziram os acontecimentos e objetos definidos por eles próprios como narrativa publicitária. As condições de existência da publicidade são ponderadas como resultado e expressão de tipos de interação social e ação coletiva, principalmente dentro das agências. Ou seja, um caminho profícuo para entender as narrativas que a publicidade disponibiliza na cultura é analisar a atuação conjunta e coordenada de identidades cuja colaboração é necessária para que o trabalho aconteça. A teoria da ação coletiva, de Howard Becker (1977), indica que as estratégias de interação e os rituais são elementos básicos para compreender processos sociais, destacando a participação dos atores e o encadeamento de eventos como modeladores de um determinado sistema cultural. São as atividades coletivas, em permanente processo de negociação de identidades, significados e poderes, que criam os produtos sociais, bem como as estruturas que os sustentam. Neste trabalho, consideram-se as identidades dos sujeitos ${ }^{2}$ que produzem os anúncios dentro de uma agência de

\footnotetext{
${ }^{1}$ Os termos "publicidade" e "propaganda" serão usados como sinônimos por uma questão de estilo. Em todo o trabalho, se referenciam às mensagens produzidas por agências e difundidas por meios de comunicação em espaços pagos sob a chancela de um anunciante público.

${ }^{2}$ Os termos "sujeito", "ator social" ou "agente social" serão alternados também por uma questão de estilo. Em todo o trabalho, as expressões se referem aos agentes ativos da história, com
} 
propaganda, seus elos cooperativos e redes de convenções para a materialização desse tipo específico de comunicação.

Esta abordagem também indica o lugar da publicidade como uma narrativa central no tempo presente, uma vez que ela produz um tipo de acontecimento - o anúncio - que modela, define e transforma nossas experiências, representações e práticas de consumo. Desta forma, o consumo é o ponto de referência, não só para o entendimento, como para a própria construção da tradição. A publicidade é um discurso que projeta uma interpretação da realidade, que articula e hierarquiza sujeitos e comportamentos, visando o acontecimento do consumo. O fenômeno é colocado como um elemento comunicativo que relaciona as ideias socialmente incorporadas em uma cultura.

A publicidade é sugerida como espaço simbólico para o qual as mais diferentes formas de comunicação, tanto podem convergir, quanto, em alguma medida, são por ela sustentadas. Os processos de construção da realidade social têm nas plataformas midiáticas, sejam tradicionais ou novas, e nos dispositivos de mensagens, sobretudo a publicidade, importantes mediadores do espaço e da experiência humana, conforme sugerem Berger e Luckmann (2002 [1966]). Desta forma, este estudo da publicidade pretende oferecer uma perspectiva do processo relacional em que os atores sociais ordenam e atualizam constantemente os movimentos do mundo em que estão inseridos, dinamizando assim as simbologias e práticas sociais, inserindo-as na cultura e na história. Levando-se em conta a abordagem de Chartier (1990), a cultura pode ser examinada através da relação interativa entre práticas e representações. Tanto os objetos culturais, como os sujeitos produtores e consumidores gravitam entre esses dois polos.

Este projeto nasce como um desdobramento das pesquisas feitas no mestrado, realizado no Programa de Pós-Graduação em Comunicação da PUCRio, sob orientação do Professor Doutor Everardo Rocha, e concluído em 2012. Ao estudar os movimentos de convergência de mídia, apropriados pelos meios de massa, pude observar como o escopo publicitário se materializa e organiza os signos presentes no crescente intercâmbio entre os meios massivos e digitais. $\mathrm{O}$ programa Fantástico, da TV Globo, foi o objeto destacado para a interpretação destas transformações que impactam o campo da comunicação. O estudo, que 
privilegiou a televisão como foco da pesquisa, também ponderou o posicionamento da publicidade e do consumo como alicerces das mensagens, escolhas, presenças e ausências editoriais nos meios de comunicação. Estas reflexões precedentes abriram caminhos para pensar a publicidade como uma espécie de arranjador dos significados estabelecidos na sociedade modernocontemporânea ao longo do tempo.

A minha experiência como professora da graduação do Departamento de Comunicação Social da PUC-Rio também me levou a desenvolver estudos relacionados à história da publicidade no Brasil, sobretudo como forma de reflexão teórica que apoie as práticas produtivas dos alunos experimentadas em sala de aula e nos laboratórios. Como editora-chefe do núcleo de televisão do Portal PUC-Rio Digital ${ }^{3}$, oriento a produção de vídeos, documentários institucionais e peças de divulgação de produtos idealizados no curso de Comunicação, tais como filmes de alunos de Cinema e eventos acadêmicos. Neste sentido, a elaboração da tese e as disciplinas cursadas durante a pós-graduação permitiram um mergulho em minhas principais áreas de interesse, sendo extremamente importante para o meu aprimoramento profissional e pessoal.

Minha participação no PECC, Programa de Estudos em Comunicação e Consumo do PPGCOM da PUC-Rio, também contribuiu para a escolha do tema. Desde 2011, este grupo de pesquisa desenvolve estudos sobre o universo do consumo, sua dimensão como sistema cultural e narrativa permanente nos meios de comunicação. Ao privilegiar o consumo como fenômeno de investigação da cultura ocidental, a produção acadêmica do PECC busca interpretar questões do mundo dos negócios sob o viés teórico. A troca intelectual já resultou em dois livros: Cultura e imaginação publicitária (Rocha; Pereira, 2013) e Cultura e experiência midiática (Rocha et al, 2014), além de diversos artigos e seminários. Estas foram as principais motivações que provocaram a imersão nessa história.

Hunt (2001) aponta o pesquisador como um produto da história, ou seja, a criação da abordagem crítica é enraizada na experiência e no olhar do investigador. Neste sentido, meu ponto de vista nesta tese tem o propósito de

\footnotetext{
${ }^{3}$ O Portal PUC-Rio Digital é o laboratório de convergência de mídia do Departamento de Comunicação Social da PUC-Rio. Na plataforma da internet, produzimos reportagens e conteúdos informativos em formato de texto, áudio e vídeo. Toda a produção é elaborada por alunosestagiários e orientada por professores. www.puc-rio.br/puc-riodigital
} 
considerar a história da publicidade no Brasil, através da trajetória das agências de propaganda. A organização do campo pelo surgimento de empresas que criam um modelo de negócios é um marco fundamental das transformações do setor e da influência cultural que emerge da interseção entre publicidade, meios de comunicação e atores sociais no Brasil.

É possível visualizar o passado de diversas formas. Tal asserção nos fez escolher a agência como guia que vai funcionar como uma espécie de "espinha dorsal" deste trabalho, a estrutura que nos leva a pensar a publicidade no Brasil. A agência é a arena que reúne todos os elementos para que o anúncio aconteça socialmente. É a partir da agência que a publicidade se expande e reverbera seus significados em nosso tempo. A história da publicidade será, portanto, investigada tendo como eixo o desenvolvimento das principais agências em território nacional. Não temos a pretensão de contar a história de todas as agências que já existiram no Brasil, tarefa que seria de difícil condução e que estaria além do possível neste trabalho. Procuramos, portanto, selecionar as agências que, de uma forma ou de outra, com mais ou menos ênfase, impactaram a construção e o desenvolvimento do mercado.

"Dos tempos heroicos" 4 ao cotidiano recente do que se tornou uma poderosa indústria, hoje respeitada e premiada internacionalmente, o atual mercado brasileiro de publicidade é o quinto maior do mundo, e movimenta mais de vinte bilhões de dólares por ano ${ }^{5}$. Esta pesquisa permitiu detectar que, além de uma indústria desse porte, a publicidade, desde o início, não só representou, como também foi responsável por construir códigos culturais experimentados na vida cotidiana, atuando como parte central do processo de criação de significados na cultura brasileira (Wagner, 2010 [1975]).

As agências são as instâncias responsáveis pela criação e circulação da mensagem publicitária, bem como são as idealizadoras do que entendemos por uma narrativa publicitária compartilhada socialmente. Assim, a formação das empresas de propaganda, o reconhecimento da profissão, a imagem do

\footnotetext{
${ }^{4}$ No livro raro Os tempos heroicos da propaganda, o autor Genival Rabelo (1956) publica reportagens feitas para a revista $P N$ sobre as agências pioneiras. Nas principais publicações sobre o segmento convencionou-se chamar de "tempos heroicos da propaganda" o período que vai de 1914 a 1935, data de fundação das agências mais antigas do país.

${ }^{5}$ Fonte: Meio e Mensagem. Reportagem: Mercado brasileiro já é quinto maior do mundo. Disponível

em: $\quad$ http://www.meioemensagem.com.br/home/midia/noticias/2012/06/27/Mercado-brasileirosera-o-quinto-maior-em-2014.html
} 
profissional, o aperfeiçoamento das técnicas, a expansão da indústria são expressões das tramas que interligam as representações discursivas da propaganda ao processo de construção social da realidade (Berger; Luckman, 2002 [1966]).

Para embasar as questões propostas, este estudo faz uso de diferentes possiblidades previstas pelo que se convencionou chamar de metodologia qualitativa. O exercício da hermenêutica é uma proposta adequada para reinterpretar, reelaborar historicamente os sentidos e os significados dos acontecimentos, fatos e coisas (Bastos; Dayrell Porto, 2006). A teoria geral da interpretação avalia as ocorrências mediadas pela linguagem. Toda interpretação é também uma forma de simbolizar novamente - o que, às vezes, chamam ressignificação - construir novos significados através dos signos analisados, alargando assim a perspectiva crítica da ciência. Assim, a hermenêutica pretende promover desvelamentos de sentido, instituindo uma construtiva experiência na dimensão comunicacional. A hermenêutica efetua uma “(...) compreensão antropológica ou uma tradução de uma realidade, a nossa realidade, isto é, a nossa maneira de captar o real, do conhecimento do ser pelo homem." (BASTOS; DAYRELL PORTO, 2006: 317).

Em concordância com esta ordenação, o estudo também pretende se valer de uma perspectiva que preserva o espírito etnográfico, no sentido de decodificar representações explorando fenômenos particulares que permitam revelar o pensamento dos grupos sociais, entre eles a própria categoria dos publicitários. Também a observação participante em algumas agências e as entrevistas em profundidade foram procedimentos adotados. Assim, em São Paulo, principal mercado de publicidade do país, conheci e estudei as agências DM9DDB, Loducca e Ogilvy \& Mather. Esta última ocupa o segundo lugar no ranking das maiores empresas de publicidade do Brasil, segundo estudo do Ibope divulgado em dezembro de $2014^{6}$. No Rio de Janeiro, estive presente na agência África Rio. A imersão nesses ambientes de trabalho foi guiada por profissionais que aceitaram colaborar com nosso estudo. Em cada visita, percorri os diferentes setores das agências acompanhada de um funcionário submetido a um dos Diretores de Criação, observei as dinâmicas e relações envolvidas no planejamento e produção

\footnotetext{
${ }^{6}$ Fonte: http://www.ibope.com.br/ptbr/conhecimento/TabelasMidia/rankingdeagencias/Paginas/AGÊNCIAS---50---MAIORES--2014.aspx
} 
de anúncios, examinei as divisões arquitetônicas que demarcam espaços e hierarquias profissionais, adornos decorativos, exposições de prêmios, vestimentas usuais de cada cargo. Também foi possível avaliar o ritmo de trabalho empreendido nos vários segmentos, bem como os espaços comuns, na maioria das vezes dedicados ao descanso ou "ócio criativo" - expressão habitualmente usada por publicitários. A opção por grandes agências ocorreu em decorrência da autoridade que estas empresas possuem na organização dos moldes e convenções do setor. Embora estejamos presenciando um aumento de empresas enxutas, com atuações bem setorizadas ou posicionadas e, muitas vezes, digitais, o padrão de mercado ainda é gerenciado pelos principais conglomerados. De certa forma, a internet trouxe a possibilidade de diminuição, ou mesmo eliminação, de um espaço físico para o encontro de profissionais e elaboração das atividades de trabalho em diversos setores da comunicação, o que supõe mudanças nas convenções de cada campo. No entanto, o setor publicitário ainda é estruturado pelo modelo usado por grandes agências.

A etnografia, como assegura Geertz (1989 [1973]), busca promover uma interpretação das culturas através do que pensam os seus atores sociais, contextualizando, ainda mais, os resultados obtidos no trabalho de campo. O conhecimento científico é suscitado pela imersão no ponto de vista nativo (Geertz, 1989 [1973]), através do estudo e percepção dos indivíduos presentes em cada sociedade. Neste sentido, o cuidado etnográfico passa pelo distanciamento do pesquisador e pela busca da relativização. Geertz ensina que “(...) praticar a etnografia é estabelecer relações, selecionar informantes, transcrever textos, levantar genealogias, mapear campos (...)” (Geertz, 1989 [1973]: 04).

Sendo assim, realizei entrevistas com publicitários que ajudaram a dar forma ao setor no país, participando dos primeiros movimentos desta história e outros que, de uma forma ou de outra, impactaram a organização do campo em décadas mais recentes. Entre eles: Alexandre José Periscinoto, Mauro Matos, Lula Vieira, Washington Olivetto, José Guilherme Vereza e Otto Pajunk ${ }^{7}$. Os entrevistados responderam perguntas sobre suas trajetórias profissionais, momentos marcantes da carreira, percepções sobre os principais movimentos históricos do campo da publicidade, crescimento do setor no Brasil, modelo de

\footnotetext{
${ }^{7}$ Nomes relacionados de acordo com a antiguidade na profissão - da mais antiga para a mais nova.
} 
negócios adotado nas agências onde cada um trabalhou, influência internacional na composição de convenções do setor, etapas para a criação de peças publicitárias, tecnologias que transformaram a prática profissional e divisões hierárquicas nas agências.

A entrevista com Alexandre José Periscinoto foi realizada no dia 31 de março de 2015, em seu escritório em São Paulo. O premiado publicitário foi sócio e Diretor de Criação da agência Almap de 1960 a 1998. Foi o primeiro brasileiro a ser jurado no Festival de Cannes, e teve como clientes as maiores empresas do Brasil. Em 2000, recebeu a estatueta de ouro do Prêmio Colunistas, uma das maiores homenagens da propaganda brasileira.

Mauro Matos me recebeu em sua casa no Rio de Janeiro para uma longa entrevista realizada em 08 de janeiro de 2015. Matos fundou a agência Comunicação Contemporânea em 1983, com Armando Strozenberg e José Antônio Calazans. Nesta empresa conquistou importantes prêmios, e um dos mais destacados foi o filme "Democracia", feito para o Jornal do Brasil, considerado comercial do ano de 1985/86 pelo Prêmio Colunistas Brasil. Em 1999, recebeu o Prêmio Caboré, do Meio \& Mensagem, que o reconhecia como um dos vinte profissionais e empresários que mais contribuíram para o desenvolvimento da propaganda no Brasil nos últimos vinte anos. Em 2003 foi considerado Publicitário do Ano pela Associação Brasileira de Propaganda.

O publicitário Lula Vieira também foi entrevistado em sua casa, no Rio de Janeiro, no dia 18 de maio de 2013. Vieira fundou a primeira agência de publicidade de Brasília, o Grupo Jovem, e trabalhou em grandes empresas de publicidade, como Lintas e JWT. Em 1982, inaugurou, com Valdir Siqueira, a agência $V \& S$ Propaganda. Conquistou inúmeros prêmios, entre os quais: Leão de Ouro, no Festival de Cannes e Clio Awards. Foi eleito Publicitário do Ano, no Prêmio Colunistas dos anos de 1990 e 1991.

A entrevista com Washington Olivetto foi feita por e-mail em março de 2015. Olivetto trabalhou como redator na $D P Z$ de 1973 a 1986. Nesta agência, criou a peça "Garoto Bombril", uma das mais premiadas da história da publicidade brasileira. Em 1986, assumiu a presidência da agência multinacional GGK no Brasil, e em 1989 fundou a W/Brasil, empresa que desenvolveu campanhas de grande repercussão. Em 1999, foi eleito Publicitário do Século pela Associação Latino-Americana de Agências de Publicidade (Alap). 
José Guilherme Vereza foi entrevistado no dia 14 de dezembro de 2014, em sua casa, no Rio de Janeiro. Vereza foi Redator em grandes agências, como DPZ, Estrutural, Esquire e Publicità. Na Contemporânea foi Diretor de Criação, função que desempenha até hoje. Acumula importantes prêmios publicitários, entre eles um Leão de Prata no Festival de Cannes; Redator do Ano, em 1992, e Diretor de Criação do Ano, em 1996, ambos pela Associação Brasileira de Propaganda.

A conversa com Otto Pajunk foi realizada na PUC-Rio, após sua participação no Seminário Transmídia Week, no dia 26 de outubro de 2015, quando falou sobre os desafios do universo digital e das redes sociais na produção publicitária. Pajunk é ex-aluno da PUC-Rio e Diretor de Criação da agência África Rio. Com apenas 27 anos, já acumula prêmios importantes, como Leões de Ouro no Festival de Cannes, London International Awards e El Ojo de Iberoamerica.

Apesar da não identificação ser parte da ética etnográfica a fim de preservar os informantes, optamos por nomear os publicitários entrevistados. São profissionais reconhecidos no campo e, alguns deles, notórios também para o público em geral, quase que como figuras públicas. Consideramos que, para esta abordagem, será relevante a identidade dos informantes. Todos os depoimentos foram liberadas para uso nesta tese e serão usados, inclusive, em forma de citações. Entrevistas com as professoras de publicidade da PUC-Rio Claudia Brutt, Mariana Palmeira e Tatiana Siciliano e alunos de publicidade da PUC-Rio e ESPM-SP também contribuíram para uma visão mais recente e para ampliar o debate sobre diversos aspectos do campo da publicidade, com outras vozes que transitam no meio. Claudia Brutt e Mariana Palmeira foram entrevistadas na PUC-Rio, em 06 de abril de 2014. Tatiana Siciliano foi entrevistada no dia 26 de novembro de 2015, também na PUC-Rio. Os professores falaram sobre a importância do diploma para a legitimação da profissão, mercado de trabalho e desafios para o futuro da publicidade. Os alunos da PUC-Rio e da ESPM-SP foram entrevistados em suas respectivas universidades no período de março a junho de 2015, e responderam perguntas sobre ingresso no mercado profissional e importância da universidade para a formação em comunicação e o desempenho das funções publicitárias. 
Desta forma, considera-se que ao longo de 100 anos, relatos foram contados por muitos atores e possuem numerosos registros. Aos poucos, clientes, marcas, profissionais, meios, professores e estudantes se articularam em torno de algo, antes desconhecido no país. Formaram um campo (Bourdieu, 1983 [1976]), cujo o resultado foi um dos setores mais lucrativos da nossa economia, que atua em praticamente todos os segmentos da indústria brasileira. Mas o próspero negócio da publicidade foi muito além da esfera dos números e cifras financeiras. Suas mensagens mágicas ajudaram a sustentar uma outra indústria, uma fábrica de sonhos que capturou parte do imaginário e impactou a vida social como um todo: a comunicação de massa ou indústria midiática. Nos capítulos que se seguem, esses componentes entram em diálogo.

No primeiro, uma revisão de literatura sobre a história da publicidade no Brasil levanta parte das pesquisas sobre o campo do consumo e da propaganda, e mostra que a publicidade se tornou um profícuo objeto de estudos que compreende várias disciplinas. Os enquadramentos analíticos disponíveis contribuíram para diferentes dimensões teóricas adotadas e, a maioria deles, reforçaram a perspectiva culturalista ${ }^{8}$ adotada por esta tese. A publicidade vista como produção sócio-histórica pode ser caracterizada como memória discursiva de uma coletividade.

No segundo capítulo, a publicidade será analisada conceitualmente, definindo o que, para efeitos deste estudo, pode ser considerado trabalho ou mensagem publicitária. Neste sentido, a publicidade se estabelece como uma discussão do nosso tempo, a partir de certas condições de possibilidades que foram determinantes para demarcar um campo profissional e uma produção material e simbólica específica. Uma reflexão que só é possível ser feita a partir da constituição do que chamamos de modernidade e da inserção em uma cultura que passamos a denominar de massiva. As estruturas produtivas decorrentes da industrialização - processo histórico e simbólico que se alastra na segunda metade do século XVIII - reorganizam a base produtiva agrária e artesanal em direção a uma composição urbana e desenvolvimentista da indústria, com grande apelo ao pensamento racional e tecnicista. Tais transformações referenciaram um novo

\footnotetext{
${ }^{8}$ A expressão "perspectiva culturalista" será usada para os estudos de antropólogos e historiadores que influenciaram esta investigação. São trabalhos que compreendem a publicidade por sua função comunicativa, seu papel nas trocas de sociabilidades e intercâmbio de códigos sociais. Análises que dão atenção ao plano dos significados que a publicidade deposita na cultura.
} 
momento do sistema social ancorado em condições até então desconhecidas na história da humanidade. A publicidade moderna estaria ligada a fatores como o incremento da produção capitalista, o desenvolvimento tecnológico, a formação da vida urbana, a expansão do mercado consumidor, dos meios de comunicação e a organização de uma cadeia de atividades profissionais. Assim, esse corte histórico é fundamental para entendermos a narrativa publicitária como resultado de uma ação coletiva entre indivíduos arranjados em torno de estruturas produtivas específicas de determinado período. Também será ressaltada a preponderância do consumo na construção das identidades e a publicidade como um importante articulador dos sentidos culturais, sua função classificatória e de troca simbólica entre sujeitos e objetos.

No capítulo seguinte utilizo a perspectiva teórica de Howard Becker (1977, 1977a) para mostrar como o processo de formação do campo publicitário, através das agências, está ligado a uma cadeia de ações coletivas entre atores sociais. O intuito é descortinar todas as atividades necessárias e as redes interligadas para que a publicidade apareça como um realidade socialmente legitimada. A partir de sua compreensão dentro dos parâmetros históricos do capitalismo, a constituição das agências de propaganda se materializa como a estrutura necessária para proporcionar o surgimento do anúncio como necessidade do processo produtivo. O interacionismo simbólico de Becker (1977, 1977a, 1986) será aplicado para uma interpretação da estrutura funcional e dos modos de relação operacionalizados nas agências. Com estas empresas, reunimos as cadeias de pessoas, os tipos de interação e as convenções do meio para que a publicidade produza o acontecimento do anúncio e demarque a profissão de publicitário, suas representações sociais e seu reconhecimento jurídico. A teoria da ação coletiva irá mostrar que o comportamento de indivíduos ou grupos, valores morais, estereótipos, bem como a criação de estruturas ou instituições sociais são resultados de mecanismos de interação, de elos estabelecidos socialmente, redes que colocam atores sociais em conexão e interdependência. São as atividades coletivas humanas que criam, tanto os produtos sociais e as composições de identidade, quanto permitem seus próprios sistemas de criação.

No quarto capítulo irei enfim interpretar a trajetória da publicidade, através da formação das agências. A criação da pioneira Eclética, primeira agência nacional, será o ponto de partida. Esta empresa, que atuava de maneira 
muito incipiente, mais como corretora de anúncios em jornais do que como criadora de mensagens persuasivas, ampliar-se-á e será determinante para o nascedouro de um campo, sua organização empresarial e posterior reconhecimento da profissão. O fortalecimento econômico do mercado, a partir dos anos 1930, atrai a indústria norte-americana, o que provoca uma estruturação mais definida nas práticas de propaganda no Brasil. Com um modelo de negócios conhecido desde meados do século XIX, as agências estrangeiras o reproduzem em nosso mercado. O consumo se torna uma via de expressão desta influencia internacional em nossos estilos de vida. O desenvolvimento das agências se articula e acompanha as transformações da imprensa nas primeiras décadas do século XX e o surgimento do rádio, que se firma como um propagador de mensagens que despertam emoções, impactam subjetividades e estabelecem outros tipos de relações comunicativas. Adiante, a televisão se consolida como o grande meio de comunicação que vai organizar a agenda social (Aucar; Rocha, 2012) e oferecer novos parâmetros produtivos para a publicidade. A industrialização crescente, as mudanças políticas, a circulação de marcas sofisticadas e os estímulos governamentais a alguns setores da indústria provocam um alargamento do mercado e abrem espaço para a profissionalização e a consolidação da propaganda no país.

O capítulo cinco retrata especificamente um momento muito próspero da publicidade brasileira. A onda revolucionária que tomou conta do mundo a partir dos anos 1960 irá quebrar antigos padrões e gerar uma atmosfera de ousadia e modernização no mercado. A criatividade é fixada como a principal ferramenta produtiva e define modelos usados pelas agências até hoje. A reconfiguração dos processos de produção de anúncios se dá inicialmente com a invenção das "duplas de criação", em que Redatores e Diretores de Arte são postos para trabalhar em conjunto. A estrutura interna das agências é modificada e o Departamento de Criação ganha poder. Presenciamos o crescimento das agências internacionais com o aperfeiçoamento de técnicas de marketing e pesquisa, além do impulso de algumas agências brasileiras que conseguiram disputar mercado em igualdade de condições com as empresas estrangeiras. O período marca o amadurecimento da propaganda no país, o reconhecimento internacional de nossa produção e o aparecimento de agências que fizeram e ainda fazem história. Uma forma 
agradável de acompanhar os processos acima, para o caso norte-americano, é através da seriado Mad Men (EUA, 2007).

Por fim, no sexto capítulo, os múltiplos prêmios internacionais, o renome das nossas agências e o volume do mercado posicionaram o Brasil entre as referências mundiais do campo. Os processos de globalização e a chegada da internet dinamizaram a estrutura das agências e o processo de produção de anúncios. Os executivos do setor administraram incontáveis crises econômicas e políticas de décadas anteriores, e muitos partiram para grandes fusões com empresas internacionais. Entender o mundo virtual e esse consumidor que transita entre experiências on-line e off-line é uma necessidade que está pautando o setor. A fragmentação dos meios, as possibilidades por demanda, a personalização, a facilidade de interação com empresas e consumidores (B2B - business to business e B2C - business to consumer) e a portabilidade das tecnologias da comunicação marcam um mundo em mutação acelerada e que exige novas habilidades dos publicitários. O profissional multimídia e conectado terá que lidar com os desafios da internacionalização, dos intercâmbios culturais, dos conflitos nas subjetividades, além de transitar com facilidade entre os meios massivos e digitais para construir a narrativa publicitária do tempo presente.

Embora a linearidade dos fatos seja uma chave importante para entender os processos sociais, é preciso ressaltar a adoção de uma abordagem interpretativa, que procurar articular seu eixo de reflexão, no caso a agência de publicidade, em um conjunto de elementos que integram um dado sistema. A pesquisa busca destacar a relevância histórica de uma prática que produz uma abundância de significados e tem, tanto no processo de produção de si mesma, quanto no processo de seu consumo, polos substanciais para a edificação de conteúdos.

A história é entendida através de uma interpretação dos fatos do passado que chegam até o presente. Escolhemos o olhar que procura vestígios e traços que voltam ou persistem na atualidade e permitem entender a adequação histórica da publicidade ao longo de um século. A história não é o pano de fundo onde as ações se desenrolam, e sim uma dimensão construtora de fatos e identidades sociais (Chartier, 1990). Nesse sentido, a história cultural embasa essa abordagem, que quer realçar o papel do homem e suas ações sociais. Através de "práticas" e "representações", a história cultural examina a atuação dos sujeitos, os objetos 
culturais produzidos e sua recepção, bem como os sistemas de elaboração destas cadeias produtivas, seus suportes de difusão cultural e suas normas de conformação (Chartier, 1990). Além do que, tudo isso está condicionado a cada movimento dado, uma vez que: “A história cultural, tal como a entendemos, tem por principal objeto identificar o modo como em diferentes lugares e momentos uma determinada realidade social é construída, pensada, dada a ler." (CHARTIER, 1990: 16-17).

A perspectiva de história cultural supõe e enfatiza o diálogo com outras disciplinas, frequentemente combinando abordagens da Antropologia e da História para privilegiar a ação humana nas tradições da cultura, reconhecendo a diversidade e a extensa duração dos fenômenos. $\mathrm{O}$ foco fundamental recai sobre a representação de determinada cultura em um dado tempo e lugar, deixando de mirar Estados, guerras e representações diplomáticas para refletir a atividade do homem e suas atuações (Hunt, 2001). As antigas concepções passam a ser substituídas por uma espécie de valorização dos atores, agentes e seus atos concretos. O caráter multidisciplinar da história cultural faz com que acadêmicos de várias disciplinas - não só historiadores - contribuam para seu desenvolvimento teórico.

A influência da antropologia cultural, com destaque para Clifford Geertz, favoreceu estudos preocupados com a cultura como “(...) um sistema de concepções herdadas, expressas em formas simbólicas, por meio das quais os homens se comunicam, perpetuam e desenvolvem seu conhecimento e suas atividades em relação à vida." (GEERTZ, 1989 [1973]: 66). Para Burke (2005), a ideia de tradição está intimamente ligada à cultura. Portanto, essa pesquisa está acordada com a perspectiva que dá enfoque à diversidade de experiências culturais e à necessidade de compreender as obras humanas. O homem é visto como integrante de uma sociedade e junto com seus companheiros coopera para a manutenção ou mudança de determinada ordenação. Chartier (1990) enfatiza a "diferenciação" na composição de uma história sensível às apropriações de materiais ou práticas comuns. A atenção aos detalhes, o olhar microscópico, como indicou Geertz (1989 [1973]), é de grande importância para atingir questões sociais mais amplas. Esse empenho reduziu a proporcionalidade das observações e combinou práticas da micro-historiografia à história cultural. A atenção também 
dada à alteridade (Lévi-Strauss, 1973 [1952]) mostra-se um importante esforço de compreender um mundo através da diferença ou do outro.

Com a interpretação dos sinais do passado, mesmo com a inevitabilidade das percepções do presente, montamos um inventário de ideias que nos leva a uma reflexão sobre um campo. Só se pode olhar para o passado com um olhar subjetivo, assim como lançar perguntas igualmente subjetivas sobre este passado. O que não quer dizer nem que o passado não aconteceu e nem que a história deva ser vista apenas como doxa (crença comum, opinião popular) ou epistéme (o verdadeiro conhecimento, verdadeiro saber) (Barbosa, 2007). No entanto, é preciso levar em conta o aspecto ficcional da história, uma vez que o relato é feito por um pesquisador inserido em um mundo distante temporalmente daquele que percorreu através de dados e fontes. O narrador está inserido no tempo presente, confinado a revisitar o passado dentro dos limites da interpretação (Barbosa, 2007). Não é possível trazer os acontecimentos de outrora ao presente sem modificá-los. Por isso, ressaltamos o caráter crítico da pesquisa, frisando que o nosso exercício é feito no presente, em um mundo distante e diverso daquele pesquisado. Através da narrativa textual serão destacados certos pontos, renunciados outros. São os vestígios da memória que se dão em forma de lembranças e documentos que permitem uma interpretação/ reconstrução de 100 anos de publicidade no Brasil.

O que será decifrado, através da interpretação, está sempre localizado no presente. Vendo nesses sinais a possibilidade de conter uma mensagem e atribuindo um valor a eles no presente, produz-se a interpretação indispensável na ação história. Para contar uma história há que existir vestígios, predisposição para ler e a leitura, isto é, a interpretação crítica. A historiografia implica, pois, em leituras de mensagens sobre algo considerado como ausente do nosso aqui e agora, a disponibilidade para visualizar nos indícios a mensagem (método) e sua leitura (a crítica). Para a teoria da história é fundamental o que aconteceu, como aconteceu e, sobretudo, por que aconteceu. (BARBOSA, 2007:14)

O que vai ser enfatizado aqui, o eixo de construção de nossa história da publicidade, é a dinâmica interna destas empresas de comunicação - as agências cujo estudo pode propiciar um desvelamento da lógica do campo, com suas técnicas e elementos discursivos. A agência é um indicativo de um processo comunicacional amplo, no qual conteúdos, publicitários, mídias, clientes e 
consumidores estão relacionados. Ainda que a história da publicidade tenha dado origem a muitas pesquisas nos últimos anos, a maioria dos trabalhos que se dedica ao tema foi elaborada pelos próprios publicitários que se dedicaram à tarefa de registrar suas memórias e desafios profissionais. São como que discursos nativos, originais (Geertz, 1989 [1973]), que relatam uma experiência próxima e familiar (Ramos, 1985 [1970], 1987, 1990; Ramos e Marcondes, 1995; Marcondes, 2001; Cadena, 2001; Castelo Branco et al, 1990; Barreto, 2006; Gracioso; Whitaker, 2001; Renha, 2011). Esses valiosos trabalhos adotam uma metodologia linear, de relato dos acontecimentos, calcados em momentos singulares de projeção do meio. No capítulo 1, discutiremos o principal enfoque de cada um deles.

Contudo, são necessárias novas interpretações para explicar o movimento de crescimento e consolidação da publicidade no Brasil e sua relação com nossas definições culturais, sobretudo em tempos em que os jovens parecem valorizar demasiadamente o presente. Os mecanismos sociais que vinculam nossas experiências às gerações anteriores parecem não ter apelo para aqueles que viverão o futuro. Grandes volumes de informações são construídas e desmanchadas a cada segundo. A memória e as conexões com o passado se perdem num presente intenso e interminável, fincado no ritmo acelerado da produção simbólica que desvia as atenções em direção ao próximo clique. Novas capacidades cognitivas e relações sociais estão associadas ao fascínio tecnológico e à inesgotável produção de mensagens (Canclini, 2005). Por isso, resgates de memória e esforços de compreensão e encadeamento de fatos são ainda mais importantes neste terceiro milênio.

"A publicidade é um batismo que introduz a nossa inteligência e motivação no consumo, dentro de um mundo certamente unificado pela mercadoria." (BASTOS; DAYRELL PORTO, 2006: 323). Todo batismo anuncia uma boa nova, um enunciado, uma informação até então desconhecida. Neste sentido, Rocha (1985) coloca que a publicidade introduz um nome, uma identidade, uma imagem de um produto no mundo do consumo. O papel classificatório da publicidade fica evidente quando o autor aproxima o sistema publicitário do sistema totêmico, cuja função é articular diferenças entre uma série natural com diferenças de uma série cultural. 
As mais díspares produções, venham de onde vierem, atravessam o sistema publicitário e dele retiram sua identidade. A publicidade é o "passaporte", "visto de saída" da produção e de "entrada" no consumo. A imagem de um produto, o lugar de que dispõe entre os outros é o resultado de um jogo de diferenças e contrastes. (ROCHA, 1985: 71)

Dento da perspectiva interpretativa, a pesquisa não deixa de ser ela mesma um ritual de batismo, uma vez que traz à tona fatos até então desconhecidos sob o ponto de vista crítico adotado, inevitavelmente, uma análise de significados aberta a múltiplas leituras. 


\section{1 - Consumo, publicidade e pesquisa acadêmica}

O estudo da publicidade e do consumo como sistemas que criam e operam representações coletivas tem recebido ampla atenção da academia nas últimas décadas. Desde os anos 1990 e, mais incisivamente, a partir dos anos 2000, a propaganda comercial se tornou um profícuo objeto de pesquisa em diversas disciplinas. O questionamento da publicidade enquanto produtora de significados culturais enriquece o campo da comunicação e favorece o diálogo multidisciplinar. Além de oferecer componentes para ponderar a vida social e a produção de subjetividades, problematizar a interação entre o discurso publicitário e a sociedade incita reflexões sobre as futuras práticas, contribuindo para a transmissão de conhecimentos e constituição de princípios éticos profissionais.

Em um levantamento a partir de teses e dissertações sobre publicidade publicadas nos anos 1990, Nilda Jacks (2001) pontua que pouquíssimas pesquisas haviam se dedicado ao universo da propaganda até então. A verificação apontou apenas 94 trabalhos com ênfase no tema publicidade/propaganda em um universo de 1.769 produções das principais universidades do país. A autora ressalta que o período foi marcado por questões teórico-metodológicas pouco relevantes, não conectadas à realidade histórico-cultural e com fraco diálogo com outras áreas do conhecimento.

Em análises mais recentes, Zozzoli (2010) mostra um aumento no número de trabalhos entre os anos de 2001 e 2010. O autor relacionou as pesquisas desenvolvidas no núcleo de Publicidade e Propaganda da Sociedade Brasileira de Estudos Interdisciplinares da Comunicação - Intercom, a fim de fornecer uma retrospectiva dos estudos na área e revelar tendências de investigação no Brasil. O extenso registro de 510 trabalhos apresentados ao longo desse período revela um crescimento destacável de abordagens relacionadas a ações promocionais, merchandising, patrocínio, marca e branding. Esses enfoques estão muito conectados aos estudos de marketing e as pesquisas sobre a evolução do comportamento do consumidor, desenvolvidas principalmente por disciplinas como Administração e Economia. Ensino, profissão e mercado aparecem como outros focos de interesse. Discussões em torno das linguagens e significações 
publicitárias continuam permeando os exames críticos do campo. A interseção do pensamento de autores consagrados de diversas áreas das ciências sociais, como Mikhail Bakhtin, Edgar Morin, Stuart Hall, Pierre Bourdieu, Umberto Eco, Roman Jacobson e Jean Baudrillard também foi evidenciada. Para Zozolli (2010), o panorama de questões epistemológicas revela um alto nível de discussões teóricas e técnicas, confirmando uma maturidade da reflexão acadêmica em publicidade e propaganda no Brasil.

A fundação da Associação Brasileira de Pesquisadores em Publicidade e Propaganda, ABP2, em 2010, reforça o empenho em institucionalizar o campo de estudos. A entidade aglutina os principais pesquisadores de publicidade, propaganda e consumo do país integrando 19 programas de pós-graduação, além de pesquisadores do Canadá, Chile, Espanha, Portugal. Em seus encontros anuais, Pró-Pesq PP - Encontro Nacional de Pesquisadores em Publicidade e Propaganda, são valorizadas as discussões científicas em torno da comunicação em propaganda, publicidade, mercado e consumo ${ }^{9}$. Jacks registra que o evento ampliou o número de trabalhos no campo em relação aos números verificados na década de 1990 (Jacks, 2001).

Porém, as ciências sociais demoraram a perceber e dedicar sua atenção a temas que enfatizem o consumo como uma questão cultural. A categoria de produção marcou a mais importante tradição de pesquisa da modernidade. No entanto, até os anos 1950, essa tradição dedicada às múltiplas possiblidades interpretativas da vida social oferecidas pela ideia de produção, não havia assumido a perspectiva fundamental de estudar seus resultados quando traduzida em consumo, e a inevitável constituição de significados na esfera pública que daí deriva.

O primeiro texto acadêmico que colocou o consumo como um fenômeno da cultura do nosso tempo foi escrito no fim do século XIX. Trata-se de A teoria da classe ociosa: um estudo econômico de instituições, de Thorstein Veblen, publicado em 1899. Este livro possui a virtude de indicar que o consumo não é um simples efeito reflexo da produção e mostrar que ele expressa relações sociais. Veblen (1965 [1899]) ultrapassou o viés economicista, a visão utilitária e deu atenção ao significado cultural do consumo. O estudo observa o consumo como

\footnotetext{
${ }^{9}$ www.abp2.org.br; www.eca.usp.br/propesq
} 
uma problemática social, e não apenas no plano das práticas, mas como representação coletiva.

A obra mostra também que a ocupação foi a divisora de classes na cultura antiga. Superioridade social e status alto se expressavam e se faziam representar pelo ócio. A experiência do ócio significava domínio do tempo e, portanto, “(...) demonstra a capacidade pecuniária de viver uma vida inativa.” (Veblen, 1965 [1899]: 54). Na cultura moderno-contemporânea, o consumo supera o ócio como sinalização de status. Na vida de hoje - acelerada, imprecisa, mesclada - o consumo é mais visível que o ócio como expressão de poder. Nesse sentido, opera um sistema de diferenças que agrupa e distancia, classificando as pessoas através das coisas e vice-versa. Nele, séries de produtos, objetos, serviços se articulam a grupos, estilos de vida, desejos, gostos e visões de mundo que envolvem a todos em um permanente sistema de comunicação de poder e prestígio na vida social (Rocha, 1985).

Posteriormente, Georg Simmel publica a coletânea de ensaios A filosofia da moda e outros escritos, em 1905. No artigo principal, Filosofia da moda, o autor destaca a importância do vestuário como um elemento de expressão da dinâmica social, que operacionaliza os conflitos e as diversas formações grupais. A moda é colocada como um componente de distinção de classes - além das sucessivas imitações de uma classe por outra - que envolve processos psíquicos, reconhecimento de valor e disputa entre os sexos. Esse estudo sobre moda abriu diversas possibilidades de análise dos grupos sociais e das influências do meio sobre o indivíduo. Simmel (2008 [1905]) mostrou que o consumo de bens é um indexador simbólico com força expressiva na comunicação de status e na composição das identidades culturais.

Mas foi somente na década de 1950 que a publicidade propriamente dita começa a ser mais observada por suas relações com o social e a cultura. Assim que começou a pesquisar o ambiente tecnológico para entender o funcionamento dos meios de comunicação e seus impactos na cultura, Marshall McLuhan escreveu The Mechanical Bride: folklore of industrial man, em 1951. A primeira obra do pensador canadense, pouco divulgada no Brasil, reúne análises sobre os anúncios publicitários e mudanças de percepção da cultura. McLuhan (1967 [1951]) posiciona-se a respeito das pressões sociais e psicológicas que a indústria 
da publicidade e os produtos do entretenimento geram no comportamento coletivo.

Em 1957, o estruturalista Roland Barthes usou a análise semiótica para destacar o conteúdo político presente na narrativa de revistas e propagandas. Vale ressaltar que as décadas de 1950 e 1960 marcam o triunfo do Estruturalismo na França (Dosse, 2007). Um novo olhar sobre o mundo e sobre a produção simbólica da sociedade se apresentava através do pensamento crítico de autores que elegeram a linguística como ciência piloto para o entendimento da trama social (Dosse, 2007). Na obra Mitologias, Barthes (1989 [1957]) coloca o mito como uma linguagem e avalia seu papel em nossa sociedade. Notícias do cotidiano e anúncios publicitários são ponderados como signos de um real mitificado, mascarado por interesses ideológicos. O autor realiza uma crítica à linguagem da cultura de massas, assim como examina essa linguagem, a fim de desconstruir os mitos difundidos pela comunicação midiática.

Conhecido por suas contribuições para os estudos culturais, Raymond Williams foi outro pensador que buscou compreender a sedução exercida pelos anúncios publicitários e sua importância no sistema capitalista. O artigo Publicidade: o sistema mágico foi escrito para ser um capítulo de seu livro The long revolution, de 1961. No entanto, o texto foi publicado parcialmente em 1960 na revista New Left Review e em 1969 na The Listener. O trabalho integral só ficou conhecido anos mais tarde, em 1980, na coletânea Cultura e Materialismo. Em suas análises, Williams (2011 [1980]) posiciona o desenvolvimento histórico da publicidade e seus impactos sociais a partir do crescimento do mercado capitalista no início do século XX. A publicidade é vista como uma espécie de operador mágico, similar aos códigos das sociedades mais simples, ao mesmo tempo em que convive com as mais modernas tecnologias.

O papel mitológico do materialismo cultural e o impacto das mídias na sociedade também foram questionados por Jean Baudrillard. Em 1968, o sociólogo francês conclui sua tese de mestrado intitulada $O$ sistema dos objetos, na qual problematiza o lugar que os artefatos materiais ocupam no cotidiano, classificando o poder simbólico dos bens e suas capacidades de distinção social. Na visão de Baudrillard (2008 [1968]), nossas subjetividades estão atreladas ao sistema produtivo. Assim, os objetos não possuem apenas o valor de uso ou de troca, mas um valor simbólico determinante que vai servir de base para nosso 
sistema cultural. Em A sociedade de Consumo (2010 [1970]), publicado dois anos depois, o autor aprofunda sua crítica sobre a força do consumo no estabelecimento de códigos e relações sociais. A publicidade é apontada como um reino de acontecimentos "virtuais", um discurso que vai construir mensagens ocultas e sedutoras que manipulam o imaginário e impactam as aspirações pessoais, inserindo os sujeitos em uma espécie de vertigem, realidade ilusória.

A partir da década de 1970, o rápido crescimento da produção publicitária começa a despertar maior interesse e estudos sistemáticos, sobretudo no campo da Antropologia e da Sociologia. Como objetos de investigação, o mundo dos anúncios, o fenômeno do consumo e a indústria cultural se configuram como caminhos para o entendimento da ideologia da sociedade, na medida em que evidenciam significados coletivos. Nessa direção, Roy Wagner (2010 [1975]) reflete sobre o papel da propaganda nas populações urbanas, estabelecendo relações entre publicidade e magia. No livro A invenção da cultura, de 1975, o autor coloca que a publicidade interpreta os produtos, criando para os atores sociais uma vida que os incorpore. Seu mecanismo de persuasão é similar ao papel da magia nos povos tribais, que também revestem a produção de sentidos através de analogias. O encanto da propaganda estaria em inventar vidas em um mundo onde a tecnologia pode tudo resolver, as mensagens nos convidam a absorver essa operação mágica.

O clássico artigo de Erving Goffman (1979), Gender Advertisements irá ponderar a ritualização da feminilidade nos anúncios. $\mathrm{O}$ autor pesquisou fotografias publicitárias de jornais e revistas dos anos 1970 para mostrar como a mulher é representada na publicidade. Goffman concluiu que os publicitários utilizam os rituais sociais para criar as histórias dos produtos, a fim de que seus conteúdos sejam decifrados de forma familiar pelos consumidores. A realidade é problematizada como uma espécie de encenação, logo, as imagens publicitárias seriam dramatizações da encenação social, dispositivos que apresentam de forma exagerada e estereotipada os rituais da sociedade que pretende retratar.

Mary Douglas e Baron Isherwood (2004 [1979]) reforçarão essa perspectiva ressaltando que a ciência econômica deveria levar em consideração a função comunicativa dos bens. Ao realçar seu enquadramento social, sugerem que os padrões de consumo são gerados pelas expectativas dos outros, sendo assim, têm pouco a ver com desejos individuais. Em $O$ mundo dos bens, o consumo é 
visto como um ato coletivo de troca de sociabilidades, de intercâmbio de códigos inerentes a um grupo e a uma temporalidade. Assim, deslocam a perspectiva biológica e individual, colocando o consumo como fenômeno definitivamente cultural, uma prática que supõe compartilhamento e que sem a alteridade não se sustenta. Os objetos, portanto, dialogam entre si, estabelecem conexões de significados e parâmetros de trocas sociais.

A relação entre utilitarismo e cultura novamente aparece em Cultura e razão prática, de Marshall Sahlins, publicado originalmente em 1976, mas que só chegou ao Brasil em 1979. A obra demonstra a importância da razão simbólica para a economia e o consumo. A crítica antropológica de Sahlins (1979) defende que a produção simbólica é o grande parâmetro que estabelece diferenciação entre as culturas humanas, independente do tempo e espaço, acima das atividades práticas e do materialismo. O estudo propõe que a construção de significados é a condição que determina a experiência social e, por conseguinte, a operacionalização dos sistemas mais racionais.

A questão da diferenciação entre classes sociais foi amplamente estudada por Pierre Bourdieu em uma extensa pesquisa realizada no período de 1963 a 1968. A síntese destas investigações deu origem ao livro $A$ distinção: crítica social do julgamento, lançado somente em 1979. A obra influenciou diversas áreas das ciências sociais e é considerada uma das principais publicações da carreira do sociólogo. Em uma pesquisa de campo realizada em cidades francesas, Bourdieu (2007 [1979]) entrevistou 1.217 pessoas sobre formas de aquisição da cultura. A análise aponta para diferentes modos de hierarquização, ao mostrar como as distinções minuciosas do gosto se transformaram em bases para o julgamento social. $\mathrm{O}$ autor coloca que os bens culturais possuem uma economia e uma lógica própria de valoração e poder que corresponde ao papel que eles desempenham na cultura em cada época. Os gostos funcionam como marcadores de classe e os afetos materiais são competências culturais desenvolvidas.

A ênfase teórica na perspectiva utilitária também foi revisada por Neil McKendrick, John Brewer e J. H. Plumb (1982). O consumo de bens de luxo serviu como base de sustentação para os autores pontuarem o nascimento de uma sociedade de consumo. The birth of a consumer society, de 1982, sugere que a expansão do comércio de artigos elitizados na Inglaterra do século XVIII foi um marco da penetração dos valores do consumo nas camadas mais populares, um 
dos primeiros movimentos do processo de massificação do consumo. Desta forma, a obra pondera que o crescimento do poder de compra das classes médias, o aumento da produtividade industrial e uma nova forma de conduta em relação aos bens materiais ocasionaram uma efetiva revolução pelo consumo que transformou o mundo ocidental.

No mesmo período, no Brasil, o antropólogo Everardo Rocha inaugura a tradição de estudos do consumo, ao destacar a publicidade como uma forma de expressão cultural. Em sua pesquisa de mestrado no Museu Nacional/UFRJ, no fim da década de 1970, o autor fez uma análise antropológica da publicidade, o que resultou no clássico livro Magia e Capitalismo (1985). Rocha utilizou algumas categorias da Antropologia, como magia, ritual, mito e totemismo, para explicar como a publicidade produz suas narrativas e realçar o caráter emocional e afetivo das práticas de consumo. A obra já recebeu diversas homenagens e se tornou uma referência nos estudos de antropologia do consumo e da mídia. O longo prefácio, Vendendo Totens, escrito por Roberto DaMatta (1985), destaca a importância de pensar o capitalismo através de suas estruturas invisíveis, imaginárias, mágicas.

Magia e Capitalismo estimulou o debate acadêmico em torno de temáticas sobre publicidade e consumo no país. Nestes mais de trinta anos, desde sua publicação em 1985, muitos trabalhos se apropriaram da produção publicitária como objeto para o entendimento da cultura. Uma consulta no banco de teses da Capes registra $590^{10}$ trabalhos com os termos "publicidade" e "propaganda". Observa-se que há um interesse crescente de outras áreas do conhecimento, como Administração, Direito, Desenho Industrial, Letras, História, Educação, Artes, Psicologia, nessa discussão. Nilda Jacks, Elisa Piedras, Anna Paula Knewitz e Nilse Maria Maldaner (2010) ressaltam que os olhares multidisciplinares ampliam os referenciais teóricos e geram novos problemas de pesquisa para o campo da publicidade.

Embora a melhora quantitativa tenha diversificado a reflexão acadêmica, o viés mercadológico continua a estabelecer uma dicotomia pouco produtiva que divide o debate entre aqueles que investigam métodos e práticas para a aplicação de mercado e os que contabilizam os malefícios do consumo como um agente

\footnotetext{
${ }^{10} \mathrm{http} / / /$ bancodeteses.capes.gov.br
} 
capaz de alienar o imaginário coletivo (Jacks; Piedras, 2006). Para problematizar o maior número de fatores empreendidos no ambiente da publicidade contemporânea, Jacks e Piedras (2006) partem da relação entre comunicação e cultura, apontando os estudos culturais como uma perspectiva que viabiliza explorar as ambiguidades e contradições desse processo comunicativo.

Os estudos culturais, particularmente na Inglaterra, a partir dos anos 1980, enfatizaram a importância do significado, sobretudo o significado como uma construção social (Hall, 2011). A cultura é vista como conjunto de práticas, produção e trocas de significados entre os membros de uma sociedade. A composição da cultura depende da interpretação de seus participantes sobre os significados e da produção do senso comum, como são apropriados, representados e compartilhados em cada interação social agora impactadas pela força do processo de globalização. Com a descentralização e as novas disposições territoriais multiplicam-se os significados em circulação, e os estudos começam a concentrar-se na problemática da desestabilização das identidades sociais, suas novas formas de constituição e recomposição. A dimensão subjetiva e a pluralidade dos modos de vida ganham centralidade (Escosteguy, 2010). Nesse sentido, os estudos culturais permitem transpor os determinismos econômicos ou idealismos culturais para a análise da publicidade, permitindo observar as contradições existentes entre as práticas de produção e recepção (Piedras; Jacks, 2005).

O mapeamento das relações entre publicidade e práticas sociais trouxe diferentes articulações e possibilidades de interpretação do mundo contemporâneo. Marchand (1985) sublinha a proeminência do valor discursivo da narrativa publicitária a partir da crise ou ruptura com instâncias autoritárias como a família e a religião. O declínio dos modelos tradicionais vai favorecer o cultivo de valores calcados no individualismo e na urbanidade. Mesmo que de forma indireta, a publicidade contribuiu para validar esses novos estilos de vida do mundo moderno, como argumenta Lears (1994). Marchand (1985) se debruça sobre o período de 1920 a 1940 para mostrar como o setor publicitário projetou o sonho americano através do consumo. A obra oferece um retrato cuidadoso das agências e atores sociais do período. Lears (1994) também traça um panorama de como os anúncios norte-americanos se tornaram poderosos ícones em todo o mundo. A tese coloca a abundância material como expressão dos códigos 
econômicos e sociais estadunidenses, modelados por uma espécie de alienação mágica e hedonista do mundo industrial. Para o autor, desde o início do século $\mathrm{XX}$, a indústria publicitária incentivou uma nova forma de pensar, corroborando com várias instituições culturais para produzir as aspirações dominantes e noções de identidade pessoal. Após a Segunda Guerra Mundial, os Estados Unidos acentuam fortemente a noção de que o ideal de felicidade poderia ser atingido através do consumo. A corrida pela supremacia no mundo ocidental era fomentada pela publicidade e a projeção da imagem de uma sociedade da abundância.

Ao examinar as culturas contemporâneas pelo viés da comunicação, é possível perceber as funções da linguagem publicitária na circulação dos sentidos experimentados nas práticas ao longo do tempo. A realidade passa a ser representada por um cenário criado a partir dos símbolos, mitologias e representações dos meios de comunicação de massa, como atesta Edgar Morin (1989 [1962]). A publicidade funciona como espelho e produtor cultural, daí a sua relação íntima com o público e sua importância para a compreensão da vida cotidiana em diferentes contextos. A criação e a preservação de determinados signos estão intimamente ligados aos mecanismos comunicacionais que, por vezes, cumprem o papel de instâncias legitimadoras da cultura.

Autores ingleses se destacam no exame destas questões. Na obra Material Culture anda mass consumption, Daniel Miller (1987) combate a negligência da academia pelos estudos do consumo, e defende que o emprego social dos bens de consumo fabricam o mundo cultural. Assim, a cultura material se apresenta como um campo de investigação que contribui para o entendimento dos processos sociais do mundo em que vivemos. A ação humana é o ponto-chave que vai determinar as escolhas para a marcação de identidades e representações. A abordagem que relaciona o consumo com a definição de identidades e subjetividades também é pensada por Collin Campbell (1987). A ética romântica e o espírito do consumismo moderno, de 1987, demonstra os vínculos entre os valores do romantismo e o consumo, correlacionando fenômenos como moda e literatura de ficção. Campbell (1987) atualiza e complementa a teoria da ética protestante, de Max Weber (1985 [1904]), ao relacionar o espírito romântico, oriundo do século XVIII, com a ética do produtivismo. O homem sensível e 
romântico de quase três séculos atrás já tinha como característica a busca pelo prazer através dos bens materiais, fazendo girar a dinâmica capitalista.

No mundo moderno-contemporâneo, a publicidade é a narrativa que dará voz ao fenômeno do consumo, um grande sistema de compartilhamento de significados de nossa época (Rocha, 1985). Muitas ideologias, modos de comportamento ou estilos de vida são acionados pelos simbolismos contidos em bens materiais. Os significados estão em constante trânsito e fluem por diversas localizações no mundo social, auxiliados pelos mecanismos e técnicas de transferência de sentidos, produzidos em cada temporalidade específica, como demonstra a obra Cultura e Consumo, de Grant McCracken (2003). O consumo se estabelece como valor permanente e a publicidade como a tecnologia difusora de suas simbologias.

Assim, vale destacar as pesquisas que recortam períodos históricos para compreender certas nuances da cultura brasileira construídas com o subsídio da publicidade. A maioria desses trabalhos foi escrita por publicitários e retrata vivências de seus períodos profissionais, com relevo para pessoas, anúncios e mudanças de percepção do campo. Neste sentido, é preciso considerar o caráter nativo desses discursos, em que a familiaridade da experiência dita o tom das narrativas e oferece um ponto de vista interno do segmento (Geertz, 1989 [1973]). Embora calcados no acúmulo de conhecimento através da prática, esses relatos contribuem e fornecem rico material para o desenvolvimento das análises acadêmicas que buscaram entender o papel da publicidade na cultura nacional.

Durante muitos anos, a obra pioneira Do reclame à comunicação: pequena história da propaganda no Brasil, de Ricardo Ramos (1985 [1970]), foi tida como referência nos estudos sobre história da propaganda. Posteriormente, as pesquisas do filho de Graciliano Ramos despertaram maior produção intelectual sobre essa temática. Ricardo entrou para o ramo da publicidade nos anos 1950, e ocupou cargos de destaque nas mais importantes agências do país. O livro apresenta a história das mídias através da publicidade desde a introdução da imprensa no Brasil até o início dos anos 1990. As pesquisas de Ricardo Ramos também deram origem a 200 anos de propaganda no Brasil: do reclame ao cyber-anúncio, publicado em 1995, três anos após sua morte. O jornalista e publicitário Pyr Marcondes reuniu um compilado de entrevistas, reportagens, artigos publicados na mídia especializada e em livros anteriores para ajudar a entender o 
desenvolvimento da atividade publicitária no país, com destaque para anúncios que marcaram época. Em 2001, Marcondes lançou Uma história da propaganda brasileira. Melhores campanhas, grandes gênios da criação, personagens inesquecíveis. O autor retrata o desenvolvimento de importantes agências, principais anunciantes, premiações e a trajetória de grandes publicitários. Através do corpo histórico, a narrativa evidencia a relação entre cultura, propaganda e sociedade.

A lista pode ser ampliada com o livro Brasil: 100 anos de propaganda, de Nelson Varón Cadena, lançado em 2001. O jornalista comenta e ilustra os principais movimentos da publicidade no país de 1900 ao ano 2000. A coletânea 100 anos de propaganda (1980), organizada pela editora Abril Cultural, traz um rico mosaico de anúncios de jornais e revistas ilustradas que permite traçar um panorama da influência publicitária no cotidiano brasileiro, do ponto de vista cultural ao estético. História da propaganda no Brasil, publicado em 1990, sob a coordenação de Renato Castelo Branco, Rodolfo Lima Martensen e Fernando Reis, reúne artigos de grandes publicitários sobre diferentes aspectos do campo, como institucionalização do setor, princípios éticos, autorregulamentação, marketing, fotografia publicitária, ensino da propaganda, trajetória das agências nacionais e estrangeiras, consumo e meios de comunicação.

$\mathrm{O}$ relato das pessoas, instituições, anúncios, modismos que marcaram o campo da propaganda entre 1951 e 2001 foram reunidos por Francisco Gracioso e Roberto Whitaker Penteado (2001) no livro Cinquenta anos de vida e propaganda brasileiras, estudo que comemorou o cinquentenário da Escola Superior de Propaganda e Marketing. As peças publicitárias foram pensadas como significativas fontes para reflexões sociais, culturais, econômicas e estéticas construídas na segunda metade do século XX. A coletânea, com textos de diferentes autorias, ressalta a contribuição da propaganda para o desenvolvimento econômico do país e para a construção de um campo de estudos que reforçou a prática profissional. As bases para a criação de anúncios modernos, a utilização das técnicas de marketing e as divisões das agências oferecem um panorama histórico do setor e das regras da profissão ao longo de cinco décadas. Whitaker Penteado já havia utilizado anúncios como fonte histórica em A propaganda antiga, de 1974. Em forma de romance, a obra recompõe mensagens da Gazeta de Lisboa de 1830, publicados no Brasil e em Portugal, para esboçar um 
levantamento antropológico das linguagens típicas da época e personagens da cultura popular.

O mundo das agências de publicidade e a produção criativa dos anúncios foram estudados pelo jornalista e empresário Roberto Menna Barreto (2006). O autor fez uma reflexão crítica sobre esse ambiente profissional, suas relações políticas, movimentos institucionais e exageros da área da Criação. Os diversos contextos histórico-culturais são explicitados pelo pacto travado entre suas definições de "sedutores" (os publicitários) e os "seduzidos" (o público). O livro Agência de propaganda e as engrenagens da história vai descortinar essa “(...) comunidade fechada, refratária, muito presa a seus códigos próprios, mesmo os que regem seus conflitos internos (...)” (MENNA BARRETO, 2006: 11) para mostrar como a propaganda reflete a psicologia social.

Entre as investigações acadêmicas, podemos destacar os trabalhos dos pesquisadores João Carrascoza e Tania Hoff (2011a, 2011b). Através de anúncios das agências de propaganda veiculados na revista Publicidade e Negócios, os autores abordaram o processo de modernização e consumo no Brasil dos anos 1950, ressaltando as interseções entre o desenvolvimento econômico do país e as práticas sociais. O nascimento de uma cultura de consumo viria consolidar a publicidade como o discurso central das marcas e o papel crescente dos meios de comunicação de massa na vida cotidiana. Os temas incidem sobre a construção de uma coletividade urbana, empresarial, com novas formas de administração e estilos de vida. $\mathrm{O}$ discurso produzido pelas agências explicita as relações com as experiências culturais em um período de franca industrialização.

(...) a sociedade avança e os anunciantes são convocados a acompanhar suas transformações. Podemos afirmar que as agências promovem uma pedagogia do consumo corporativo e a publicidade torna-se a "voz" que enuncia o novo modo de fazer negócios e, por consequência, os novos significados atribuídos às práticas de consumo. (CARRASCOZA; HOFF, 2011A: 268).

A publicidade também foi objeto usado por Anna Cristina Figueiredo (1998) para compreensão do pensamento das camadas médias urbanas nos dez anos que antecederam o golpe militar. A análise dos anúncios impressos em revistas de grande circulação no país propôs revelar as motivações determinantes para o comportamento político desse segmento social urbano que apoiou o regime 
autoritário. $\mathrm{O}$ estudo intitulado Liberdade é uma calça velha, azul e desbotada mostra o grande papel da publicidade como instrumento de redefinição de identidades coletivas, uma “(...) fonte rica de imagens, valores, ideias, representações, sonhos e anseios (...) voltada para camadas médias." (FIGUEIREDO, 1998: 19). Segundo a autora, a emergência da cultura de consumo no Brasil influenciou as atitudes dos agentes sociais no âmbito privado e na esfera política.

Na sequência, as intensas transformações da década de 1960 também foram muito estudadas, tendo a propaganda como objeto. Aliado às revoluções culturais do período, tivemos um incremento da produção publicitária, com a incorporação de padrões norte-americanos que privilegiaram a criatividade como modelo de negócios. A propaganda se constituiu como um dos principais meios de difusão da ideologia militar. Essa relação singular entre as campanhas publicitárias, ditadura e imaginário social ganha relevo na obra de Carlos Fico (1997). Por meio de propagandas políticas, o governo fixa a ideia de progresso, reafirmando o mito do espírito brasileiro pacífico, alegre e patriota.

Além das agências oficiais, o governo costumava contratar algumas agências comerciais, como veremos adiante. Nesse sentido, a propaganda política se converte em publicidade comercial, uma vez que as agências tinham o governo como cliente, e sua ideologia era vista um produto que deveria ser vendido através de técnicas de persuasão, comumente utilizadas em outros bens comerciais. Para Fico (1997), o otimismo presente na narrativa publicitária não foi criado pela ditadura, e sim apropriado pela publicidade, que soube ler com eficiência os valores históricos presentes na identidade nacional. $\mathrm{O}$ autor reitera:

\footnotetext{
O regime militar criou uma propaganda política singular, que, para alcançar alto grau de propagação, se travestia de 'despolitizada', calcando-se em valores fundados num imaginário forjado por vasto material histórico. $\mathrm{O}$ que se quer é revelar o que tais valores possuem de dissimulador de nossa realidade tão conflitiva e, nesse sentido, pouco solidária. (FICO, 1997:129)
}

A autoridade das narrativas midiáticas, entre as quais os anúncios publicitários, como redes discursivas que legitimam as noções de felicidade, arranjam valores éticos e morais, modos de vida, ou referenciam paradigmas estéticos, tem sido demonstrada por Freire Filho em diversas publicações (2003, 
2007, 2010, 2011, 2012). A complexa problemática estabelecida nas relações entre mídia, consumo e produção de subjetividade inquieta o autor que destaca os imperativos de felicidade construídos e propagados pela mídia. A busca pelo "self autêntico", a expressão pública dessa autenticidade, a necessidade de autonomia individualista e a obsessão pela ideia da felicidade se tornam mensagens latentes verificadas em diversos anúncios publicitários, textos jornalísticos ou mesmo nas dinâmicas de reality shows.

Essa íntima relação entre o discurso publicitário e os processos de produção de subjetividade também pautou a problemática central da tese de Henrique Mazetti (2014). Em As marcas da felicidade: transformações do bem viver na publicidade brasileira (1960-2010), o autor examina processos de individualização expostos pela publicidade, através da analise textual de anúncios veiculados nas revistas $O$ Cruzeiro e Veja, no período de 1960 e 2010 . O estudo dessas representações publicitárias permitiu a identificação de alterações na moral que afloraram o individualismo contemporâneo. Além de esmiuçar a relação entre sujeitos e mercadorias, o trabalho se apropria da publicidade como um recurso narrativo, que oferece rico material para que os indivíduos elaborem compreensões de si mesmos e dos outros. A cultura de consumo é ponderada como responsável pela difusão e legitimação de boa parte dos valores de felicidade e da boa vida (Mazetti, 2014).

Algumas agências foram alvo de pesquisas que buscaram compreender a atividade comercial e abordar uma perspectiva histórica da comunicação. A trajetória e o sucesso de mercado da agência MPM Propaganda, inaugurada em 1957 em Porto Alegre, foi radiografada na dissertação de mestrado de André Iribure (2002). O desenvolvimento da agência ilustra a articulação entre o contexto gaúcho e o restante do país. As diversas transformações empresariais vividas pela $M P M$ explicitam a realidade brasileira do setor da publicidade como agente fundamental do sistema capitalista. Esse trabalho foi aprofundado posteriormente e deu origem ao livro MPM: a agência dos anos de ouro da publicidade brasileira (2015), fruto de uma parceria entre Iribure e sua orientadora Nilda Jacks. Entre os estudos regionais, vale destacar o trabalho de Luiz Maranhão Filho, publicado em 2002 pela Editora da Universidade de Pernambuco. No tempo do reclame ressalta casos peculiares da publicidade do Nordeste veiculados em mídia impressa, rádio e televisão. 
O aprofundamento da crise desenvolvimentista pós-golpe militar e as transformações do processo de redemocratização brasileiro a partir da década de 1980 não passaram incólumes ao campo da propaganda. O entendimento das metamorfoses da publicidade brasileira nas últimas décadas do século $\mathrm{XX}$ foi o objetivo da ampla pesquisa de Maria Eduarda da Mota Rocha (2010). A nova retórica do capital procura relacionar o discurso publicitário com o contexto político-econômico e o próprio setor profissional, apontando os significados das narrativas e os eixos de construção imagética das mercadorias. O campo publicitário e suas conexões internas e externas são ponderados como uma representação do capital na relação com o público consumidor. As mutações das agências, anunciantes e veículos de comunicação estão vinculadas às novas conformações externas, como a recessão econômica, a queda na demanda, as novas marcas em circulação, o apelo das grandes corporações, além da herança militar na reconfiguração do setor. O livro utiliza anúncios de segmentos específicos, como financeiro, automóveis, bebidas, alimentos e cigarros, para desvendar as estratégias publicitárias de maior prestígio. A publicidade é arena pela qual é possível observar as metamorfoses da sociedade brasileira e funciona como um sistema de reprodução de valores culturais no capitalismo tardio (Mota Rocha, 2010).

Por fim, vale lembrar o importante papel que a Rede Alcar vem desempenhando no resgate da memória da imprensa e da propaganda brasileiras. A Rede Alfredo de Carvalho foi formada em 2001, inicialmente com foco na pesquisa sobre história da imprensa no país. A associação reúne pesquisadores de história da mídia de vários estados brasileiros. $\mathrm{O}$ estudo da publicidade passou a contribuir com o desenvolvimento da organização a partir de 2003, no I Congresso Nacional de História da Mídia, realizado no Rio de Janeiro. Em 2005 foi lançado o livro Propaganda: história e modernidade (Queiroz, 2005), com a recuperação da história da propaganda regional, e textos de diversos redutos do país.

Esta breve revisão bibliográfica de produções relevantes ao estudo do consumo e da publicidade permite sistematizar o que já foi produzido e levantar questões incipientes. Além dos livros, teses e dissertações, as pesquisas também podem ser enriquecidas com a diversidade de produção on-line existente sobre o tema. Portais, sítios, blogs, páginas digitais de revistas e jornais impressos, canais 
de vídeos catalogam preciosos acervos. A narrativa publicitária como objeto de pesquisa em comunicação enfatiza esse dispositivo midiático como uma produção sócio-histórica, fruto dos eventos econômicos, políticos e culturais, podendo ser qualificada como memória discursiva (Carrascoza; Hoff, 2011a). Afora o discurso comercial, a publicidade se inscreve como mensagem de enunciação social a partir da polifonia e diversidade de questões sobre o consumo.

Portanto, a compreensão da experiência moderno-contemporânea passa pelo entendimento do fenômeno do consumo, da forma como criamos e nos apropriamos de produtos e serviços. O tempo presente, mais que qualquer outro, atualiza um entrelaçamento profundo dos termos dessa relação.

Os significados dos bens de consumo e a criação de significado levada a efeito pelos processos de consumo são partes importantes da estruturação de nossa realidade atual. Sem os bens de consumo, certos atos de definição do self e de definição coletiva seriam impossíveis nessa cultura. (MCCRACKEN, 2003: 11)

No próximo capítulo iremos pensar a publicidade como uma atividade ancorada em princípios do tempo presente. As definições conceituais do que, neste estudo, serão ou não consideradas como narrativa publicitária irão dirigir os desdobramentos teóricos posteriores. A reflexão parte das balizas que convencionamos adequar para caracterizar a modernidade, a cultura de massas e suas estruturas produtivas. A prevalência do consumo como uma atividade sistemática e global, que serve de base para nossas matrizes culturais, também será analisada através do papel da publicidade como um sistema classificatório que erige uma ampla e consistente simbologia na vida social. 


\section{2 - Publicidade - uma atividade do nosso tempo}

Diariamente a publicidade se faz presente em nossas vidas. Ao acordarmos e escovarmos os dentes, a marca do creme dental já nos promete um hálito fresco. No banho, uma infinidade de produtos para a higiene assegura o nosso bem estar. A roupa que escolhemos vestir carrega uma etiqueta que comunica um estilo e, de certa forma, também revela o lugar para onde vamos e como projetamos um certo comportamento naquele dia. No café da manhã, leite, biscoitos, pães, margarinas nos desejam bom dia através de fotos e dizeres que enfatizam uma vida saudável e feliz. No jornal matutino, as notícias são mescladas com propagandas de produtos e serviços. No rádio do carro, a previsão do tempo é interrompida pelo oferecimento do patrocinador. O próprio conforto do carro é garantido pelo fabricante de veículos em anúncios sonoros. Outdoors nos distraem no trânsito. O nosso cotidiano é atravessado a todo o momento por mensagens que transmitem ideias, querem persuadir, afirmar, prometer algo através de discursos bem elaborados que nos levam a adquirir mercadorias e serviços. Garantir o consumo e moldar estilos de vida, esse é o papel central da publicidade no mundo modernocontemporâneo $^{11}$.

No entanto, estas mensagens que participam da orientação dos desejos individuais e da construção do imaginário coletivo são uma formulação muito recente na história da humanidade. A publicidade tem características próprias decorrentes de nossas experiências culturais e do tempo histórico em que estamos inseridos. Trocas de objetos e relações de compra e venda são práticas existentes há séculos em muitas civilizações. É quase impossível determinar com precisão quando as atividades comerciais começaram a ser realizadas (Le Goff, 2014). O comércio é uma relação social singular ao homem, a produção de excedentes para obtenção de algum tipo de benefício posterior ou a circulação de materiais e artefatos que produzem significados sociais são práticas existentes nas mais

\footnotetext{
${ }^{11}$ Nesta tese, a expressão "moderno-contemporâneo" será usada para designar o período a partir da segunda metade do século XVIII até os dias atuais, em concordância com a perspectiva de Veblen (1965 [1899]). Para o autor, a intensificação do processo industrial europeu é uma dimensão histórica importante que rompeu com experiências anteriores e provocou uma nova disposição cultural, com base no acúmulo de bens.
} 
diversas sociedades, como mostrou Marcel Mauss (2003 [1925]) em seu elaborado estudo Ensaio sobre a Dádiva. Através de ricos dados etnográficos, Mauss descreve as regras do sistema de trocas de tribos do noroeste americano, as formas e as razões de barganha destas sociedades arcaicas. Os princípios rígidos da circulação de mercadorias, o interesse social por riquezas, a tensão entre obrigatoriedade e espontaneidade, a ligação entre oferta e retribuição nestes povos permitem, não só observações acerca do trânsito dos objetos, como evidenciam a centralidade do sistema de compartilhamento como um grande definidor de papeis nos grupos sociais. O sociólogo conclui que o chamado "sistema de prestação total", aquele em que os indivíduos e grupos trocam tudo entre si, é o mais antigo sistema econômico e jurídico que podemos constatar. A "prestação total” institui o caráter impositivo da oferta, e não envolve apenas a retribuição do presente recebido, mas subentende que as obrigações de "dar e receber" são de igual importância, além de fixar ritos e mitos ao convívio coletivo. Aquele que recusase a dar ou recusa-se a receber transmite uma informação equivalente a uma declaração de guerra, uma renúncia à aliança e à comunhão. $\mathrm{O}$ estudo demonstrou que a dádiva não é livre de interesse, existe uma contraprestação embutida, a fim de manter vínculos proveitosos entre as tribos e não apenas como forma de pagar serviços e coisas. Assim, o autor aproxima as distantes sociedades tribais da nossa maneira capitalista de gerir recursos e tempo ao apontar que a riqueza é sempre um meio de prestígio, comando e utilidade. O comércio, as trocas e as alianças foram mecanismos pelos quais os povos conseguiram aplacar as disputas sociais que costumavam ser resolvidas com a guerra sangrenta por um sistema em que as disputas passam a obedecer a regras e uma etiqueta social.

As sociedades progrediram na medida em que elas mesmas, seus subgrupos e seus indivíduos, souberam estabilizar suas relações, dar, receber e, enfim, retribuir. Para começar, foi preciso inicialmente depor as lanças. Só então se conseguiu trocar os bens e as pessoas, não mais apenas de clãs a clãs, mas de tribos a tribos, de nações a nações e - sobretudo - de indivíduos a indivíduos. Só então as pessoas souberam criar e satisfazer interesses mútuos, e, finalmente, defendê-los sem precisar recorrer às armas. (MAUSS, 2003 [1925]: 313)

Em nossas sociedades ditas civilizadas, junto aos exercícios de troca material, compra ou venda de artefatos ou bens economicamente úteis, discursos midiáticos foram elaborados para perpetuar significados. Tais discursos estão 
presentes nas diferentes formações comunitárias moderno-contemporâneas para estabelecer contratos entre as coletividades que negociam. Com a adoção continuada destes discursos, os teores se transformam em códigos de conduta, normas de comportamento, preceitos de ação grupal, indicadores que vão dar forma aos nossos hábitos, rotinas, tradições. Sendo assim, não podemos considerar qualquer discurso que envolva relações ligadas a permuta de objetos ou comercialização de produtos como narrativa publicitária. A publicidade é resultado de uma ação social entre sujeitos organizados em torno de estruturas produtivas baseadas em determinadas ordenações culturais. Neste capítulo, iremos refletir conceitualmente a publicidade como uma atividade própria da modernidade, vinculada ao sistema capitalista, à formação do mercado consumidor e à comunicação de massa.

A publicidade, que hoje engloba diversos domínios da vida coletiva e é vivenciada nas ações mais corriqueiras de nosso dia a dia, será pensada a partir do processo de industrialização que transformou substancialmente as sociedades ocidentais a partir do século XVIII. Neste sentido, a dimensão histórica é o alicerce para o entendimento deste movimento simbólico que tomou conta dos modos de vida. A Revolução Industrial provocou uma reordenação cultural universalizante, derrubou as barreiras geográficas entre nações e rompeu com experiências anteriores, como destaca Veblen (1965 [1899]):

\begin{abstract}
Gradualmente, a atividade industrial se sobrepõe à atividade predatória na vida diária da comunidade e nos hábitos de pensamento dos homens; à medida que isso acontece a acumulação de bens toma cada vez mais o lugar de troféus obtidos em façanhas predatórias, como o índice convencional de prepotência e de sucesso. Deste modo, com o crescimento de uma indústria normal, a posse da riqueza se torna relativamente mais importante e eficaz como base costumeira de estima e reputação. (VEBLEN, 1965 [1899]: 41)
\end{abstract}

Aos poucos, a ideia de produção ganha peso nas sociedades ocidentais, e a perspectiva econômica se sobrepõe às demais esferas da vida individual e coletiva, assim como também as submete às suas regras. Lévi-Strauss (1973 [1952]) acentua o caráter planetário deste marco: 
A Revolução Industrial nasceu na Europa Ocidental; depois apareceu nos Estados Unidos, seguidamente no Japão; a partir de 1917 acelerou-se na União Soviética, amanhã irá indubitavelmente surgir noutro lugar qualquer; de meio em meio século brilha com maior ou menor vivacidade neste ou naquele centro. (LÉVISTRAUSS, 1973 [1952]:73)

Levi-Strauss (1973 [1952]) aponta a existência de três tempos históricos: paleolítico, neolítico e industrial. Contudo, o autor sublinha que, com o distanciamento temporal, os dados absolutos que marcam os "tempos de surgimento" de um período histórico se tornam irrelevantes. Revoluções ou rupturas ocorrem simultaneamente em diferentes espaços e tempos. Ao argumentar sobre a Revolução Neolítica, por exemplo, considera a diferença de um ou dois séculos em relação à Revolução Industrial absolutamente desprezível. O que importa são os processos irreversíveis na cultura e a grandeza das transformações sociais.

Com a Revolução Industrial, o mercado passa a ser a instituição reguladora dos hábitos e costumes, assinalando o capitalismo como o grande sistema que orientará a vida social. Mauss (2003 [1925]) ressalta que a concepção produtivista passa a ocupar o centro da existência humana, é o motor que organizará os sistemas culturais. "O homem foi por muito tempo outra coisa e não faz muito que é uma máquina complicada de uma máquina de calcular." (MAUSS, 2003 [1925]: 307).

A nossa sociedade industrial passa a ser uma grande fábrica de produção ininterrupta. A lógica da produção vai incidir sobre tudo em nosso mundo e esse critério de submissão não deixa margem a negociação. Não se questiona o domínio econômico, ele sai do controle da sociedade e assume um funcionamento próprio e autônomo, é a maneira pela qual olhamos o mundo (Rocha, 1995). A verdade utilitária passa a traduzir o universo, todas as esferas da vida devem ser produtivas, o desperdício se torna indesejável e o ócio, condenado. Em uma sociedade que prioriza a produção a todo custo, as diferenças culturais tendem a desaparecer, uma vez que a intensidade dos processos produtivos destroem qualquer ideia ou prática que não assuma esta vertente, expande-se um mecanismo que tenta homogeneizar os padrões. É dentro do jogo capitalista, a partir destes parâmetros ideológicos, que iremos pensar a publicidade, seu sistema de classificações e suas narrativas produzidas por instituições organizadas. 
Sem a expansão global dos meios massivos a publicidade não teria plataformas para veicular e disseminar suas mensagens. No sistema simbólico da cultura de massas, a publicidade é o elemento integrador das diferenças e o sustentáculo da estrutura mercadológica dos meios. É através da publicidade que os elementos da produção adquirirão signos sociais. Logo, a publicidade é o ponto de ligação entre uma materialidade sem significado e uma produção singularizada, carregada de sentidos culturais (Rocha, 1985).

Os meios falam da sociedade em que estão inseridos de forma representativa. Como a cultura de massas é o mais poderoso sistema simbólico do nosso tempo, sua influência é irrefutável. Desta forma, mantemos um vínculo íntimo e recíproco com as todas as narrativas dos meios de comunicação. Trocamos experiências, sentimentos, ideias tanto com os habitantes de nosso mundo real, material, quanto com os habitantes da representação de sociedade transmitida pela mídia. A indústria cultural ${ }^{12}$ projetou uma duplicidade, uma dubiedade em todos os sujeitos, que transitam com desenvoltura por esses dois universos (Rocha, 1995). Assim, reconhecemos com facilidade a voz de atores e atrizes de novelas, cantamos os jingles das propagandas, organizamos nossa agenda de acordo com a grade de programação televisiva, compramos o livro do filme que acabamos de assistir, sofremos quando uma celebridade morre, associamos automaticamente o desenho de uma maçã mordida ao logotipo da empresa de tecnologia Apple, ou chegamos a desenvolver uma sensação de fome quando avistamos um M amarelo, por se tratar da conhecida marca da rede de fast food McDonald's. Enfim, vivenciamos o mundo dentro da comunicação de massa em sua plenitude. Esse acesso e essa compreensão são naturais ao homem moderno. Produtores e consumidores têm um vínculo de entendimento recíproco. Por isso, as mensagens da indústria cultural dizem muito sobre quem somos, nossos hábitos e estilos de vida, assim como também reproduzimos na esfera social os temas discutidos pelos meios. Essa simbiose ajudou a determinar nossos padrões culturais ao longo do tempo.

Entender e interpretar os significados dentro do mundo da comunicação de massa abre acesso para parte do significado que eles possuem no plano externo.

\footnotetext{
${ }^{12}$ As expressões "indústria cultural", "cultura de massas" e "comunicação de massa" serão usadas de forma intercambiada, uma vez que se referem, neste contexto, à produção simbólica fabricada pelos meios de comunicação com o intuito de atingir grandes audiências. Uma discussão sobre as diferenças e proximidades de sua história intelectual seria objeto de outro trabalho.
} 
Nossa singularidade moderno-contemporânea passou por transformações históricas significativas, sobretudo ao longo do século XX, quando gradualmente a cultura de massas assumiu papel importante na construção das subjetividades. Dentro desta forma de operação do simbólico na vida humana, a publicidade é um pilar substancial, que irá operar nas escolhas, na percepção do tempo, na fabricação dos desejos e nas categorizações entre objetos e pessoas. Portanto, vamos perceber a publicidade, histórica e conceitualmente, como uma atividade do nosso tempo.

\section{1 - Anúncio publicitário: sentidos e interpretações}

A atividade publicitária, como de resto qualquer outra, requer um contexto que a suste. A noção de "anúncio publicitário" está diretamente ligada a diversos fatores, como a organização de uma cadeia de atividades profissionais, o início da produção capitalista de massa, o aprimoramento da tecnologia, a solidificação do consumo, a comunicação de grande alcance e a expansão urbana. Sendo assim, não podemos encaixar qualquer comunicado, aviso, mensagem, declaração, chamado ou texto na categoria de "publicidade". Neste sentido, a publicidade tal como conhecemos hoje é dotada de um sentido e um fundamento capitalista que só se realiza a partir das condições econômicas e culturais da modernidade. O campo se estrutura com sistema de posições próprio, hierarquias, leis, hábitos, disputas, antagonismos, articulado à formação da sociedade de massas, do crescimento midiático e da consolidação do mercado.

Os meios de comunicação e suas narrativas estabeleceram modelos civilizatórios. É importante pensar as transformações que caracterizaram o Ocidente levando em consideração a comunicação como um elemento central para a estabilização dos códigos culturais. Dentro deste eixo histórico, de cerne capitalista, a publicidade se firma como um pilar valioso, de transformação e produção da ordem simbólica, um mediador das relações sociais. Através do interminável acervo de mensagens publicitárias já produzido na contemporaneidade, podemos conhecer significados, crenças e comportamentos. 
Neste sentido, para entender a atividade publicitária é preciso interpretá-la dentro de nosso tempo presente marcado por valores da cultura industrial e massiva. A incorporação da noção moderna de mercado consumidor na esfera cultural é um marco essencial para definir a publicidade, tanto como prática profissional, quanto como uma narrativa específica. A publicidade, do modo como a conhecemos, é adequada por componentes que se aparelham dentro de uma lógica social peculiar da modernidade. Vale lembrar que as trocas entre grupos e civilizações e a constituição de mercados consumidores são práticas milenares experimentadas por praticamente todas as culturas humanas (Le Goff, 2014). A interpretação dos códigos sociais é que se atualiza constantemente em cada tempo histórico e contexto cultural.

Não há como precisar em termos cronológicos o nascimento do comércio e a conquista de mercados como marcadores econômico-sociais, pois essa é uma questão complexa (Le Goff, 2014). Temos registros de rotas interligadas usadas no comércio entre o Oriente e a Europa desde períodos arcaicos. A Rota da Seda, como foi batizado esse antigo sistema de trocas, foi considerada a maior rede comercial do mundo antigo por onde transitavam mercadores, missionários, peregrinos, conquistadores. Através de caminhos traçados entre o extremo Oriente e as principais cidades europeias, mercadorias eram transportadas por animais, barcos e caravanas, dando forma a uma ligação comercial muito próspera entre os continentes e a futura descoberta de caminhos marítimos para a Índia. Há muitas divergências bibliográficas sobre o período exato em que essa exportação de mercadorias começou. Estima-se que a intensa circulação nesta grande rede de estradas da Rota da Seda se deu, principalmente, entre o século I e o século XV (Palazzo, 2009). Segundo Pallazzo (2009), o rico intercâmbio cultural experimentado através destes cursos não ganhou tanta atenção dos historiadores devido à excessiva valorização dos estudos em torno das chamadas Grandes Navegações, que destacam a perspectiva eurocêntrica e muitas vezes desconsideram a ligação próspera entre Oriente e Ocidente no decorrer da Idade Média.

Existiam rotas continentais e marítimas que mudaram seus itinerários várias vezes ao longo do tempo, sobretudo em virtude da situação política de cada nação. A hipótese mais comum é a de que o principal trajeto por terra dividiu-se entre o norte e o sul da China. A rota norte tinha como objetivo chegar até 
Veneza, na Itália, e a partir daí atingir outras cidades ocidentais. O percurso atravessava o Leste Europeu, a Crimeia, o mar Negro, o mar de Mármara e os Balcãs, no sudeste da Europa. A rota sul cortava o Turcomenistão, a Mesopotâmia e a Anatólia para chegar até os longínquos destinos em torno do mar Mediterrâneo, Egito e norte da África. A Rota da Seda pelo mar partia da China meridional até chegar a países como Índia, Pérsia, Egito, Itália, Portugal e Suécia (Hayashi, 1975).

Os chineses guardavam o segredo da fabricação da seda a sete chaves. O material era produzido a partir da fita branca do casulo do bicho-da-seda. A expansão comercial veio no rastro do desenvolvimento da navegação e da domesticação de animais para uso como meio de transporte. Carregamentos eram assentados e seguiam sobre o dorso de determinadas espécies como elefantes, camelos, cavalos, dromedários, búfalos e lhamas, em viagens que duravam meses ou até anos. A partir do contato com as cidades do Ocidente, os chineses perceberam que existia uma possibilidade de comércio muito rentável em torno da seda e de outros produtos. O intercâmbio comercial proporcionou uma interação cultural muito rica e a expansão dos limites geográficos conhecidos até então. $\mathrm{O}$ incremento dos transportes de longa distância trouxe agilidade para o comércio e o rápido desenvolvimento dos terrenos costeiros, próximos ao litoral, graças ao predomínio das rotas náuticas (Hayashi, 1975).

Esta interconexão geográfica foi um importante canal de comunicação para o crescimento de grandes civilizações como o Egito Antigo, Mesopotâmia, Pérsia, Índia e Roma. Com a descoberta dos caminhos, Ocidente e Oriente passaram a transmitir tecnologias, artes, ciências e religiões, em vias de mão dupla. A rota também ficou conhecida como caminho de emissários (Hayashi, 1975), devido às suas intensas misturas étnicas e culturais. A seda foi apenas o símbolo deste imenso eixo de comunicação. Diversas especiarias como canela, coentro, noz-moscada, cravo, mirra, linho, tapetes, chás, cerâmicas, porcelanas e até ervas medicinais eram levadas ao continente europeu, além de importantes inventos como o papel e a pólvora. Para a China dirigiam-se produtos como maquiagem, artigos de beleza em geral, diamantes, vidros e os conhecimentos da matemática e da medicina ocidental. As fontes materiais são especialmente representativas para a comprovação deste rico cruzamento cultural. Os trajetos, que abarcaram mais de sete mil quilômetros, também foram muito usados por 
clérigos, sacerdotes e monarcas para catequizações religiosas. Doutrinas budistas e islâmicas foram algumas das crenças expandidas por estes caminhos.

A cidade de Bizâncio ${ }^{13}$ foi considerada estratégica por muito tempo por estar localizada no meio das rotas entre a Europa e a Ásia. Outras cidades também se colocaram como ponto de encontro e concentração de comerciantes que focavam suas ações mercantis em pequenos trechos do percurso (Hayashi, 1975). Assim, podemos constatar que o comércio foi um grande organizador do cenário político e econômico de diversas populações ao redor do mundo, um importante sistema construtivo de relações sociais e modos de expansão.

A partir do século XVI podemos identificar os primórdios da formação do mercado comercial tal como o interpretamos hoje. Para Marx (1980 [1867]), esta é a ocasião embrionária das bases capitalistas. Naquele momento, os estados nacionais começam a valorizar a prosperidade econômica. Até o final do feudalismo, modo de organização social e político que predominou em grande parte da Europa Ocidental durante a Idade Média, os sistemas econômicos conhecidos eram baseados na correlação mútua, poder descentralizado nas mãos de vários senhores feudais, precária circulação monetária, trocas recíprocas entre os integrantes de uma comunidade (escambo), mão de obra servil dos camponeses em troca de proteção e abrigo, trabalho majoritariamente artesanal e firmado na agricultura de subsistência (Le Goff, 2014). Com o início das grandes navegações e expansões marítimas europeias, durante os séculos XVI, XVII e XVIII, a burguesia mercante começa a buscar riquezas em outras partes do mundo. A aventura pelos mares foi incentivada pelo desejo dos europeus de quebrar o monopólio de Veneza e Gênova em relação ao comércio de produtos liderado pelo Oriente, sobretudo depois de séculos de conhecimentos adquiridos com a expansão mercadológica através da Rota da Seda. Com o acesso aos mercados orientais, através dos principais trajetos do extremo oriente que desembocavam nestas cidades em torno do Mar Mediterrâneo, os burgueses italianos cobravam preços exorbitantes pelas especiarias. Sendo assim, a busca de trajetos alternativos de comércio para conseguir ouro, prata, matérias-primas, especiarias passa a ser o alvo da nobreza e dos comerciantes de outras partes da Europa.

\footnotetext{
${ }^{13}$ Bizâncio era o centro do Império Bizantino, porção do Império Romano que falava o idioma grego. Posteriormente, por volta do século IV, a cidade passou a se chamar Constantinopla, em homenagem ao imperador Constantino. No século XX, seu nome foi mudado novamente para Istambul (Grimal, 2001).
} 
McKendrick, Brewer e Plumb (1982) destacam o entusiasmo dos consumidores ingleses com os tecidos baratos como chita e musselina trazidos da Índia nos anos 1690. Esse interessante comércio de fontes orientais despertava a cobiça dos negociantes europeus. A necessidade de conquistar novas terras e com isso matérias-primas, pedras preciosas e produtos desconhecidos também foi outro fator de incentivo às navegações. Os reis absolutistas europeus apoiavam o empreendimento, já que o aumento do comércio significaria a elevação da arrecadação de impostos. A expansão territorial também era muito proveitosa à Igreja Católica, que estava interessada em ampliar sua base de fiéis e sua influência cultural.

Os portugueses e os espanhóis foram pioneiros nas explorações marítimas, seguindo com suas caravelas, tanto pelos contornos da África, quanto pelos caminhos rotativos do Oceano Atlântico, o que gerou o estabelecimento de relações com o continente africano, a Ásia e as Américas. Navegar por desconhecidos mares era considerado uma tarefa muito arriscada, que amedrontava os imaginários da época. Mitos em torno de mares habitados por monstros marinhos e sereias eram comuns, assim como a crença de que a Terra era um território plano, o que alimentava a ideia de que uma caravela poderia cair no abismo a qualquer momento. Diante do imenso desafio de desbravar os oceanos, Portugal foi pioneiro no exímio planejamento da viagem e desenvolveu estudos náuticos na Escola de Sagres. Bússola, quadrante, astrolábio e balestilha foram instrumentos indispensáveis para a navegação e baseavam-se na posição dos astros como referência (Koshiba; Pereira, 1996).

Outros países europeus, como França, Inglaterra e Países Baixos também partiram para a conquista de novas rotas para as Índias (nome genérico pelo qual se designava o leste da Ásia), através da exploração dos roteiros comerciais portugueses e espanhóis traçados pelo Oceano Pacífico, o que ocasionou a descoberta da Austrália pelo navegador holandês Willem Janszoon, em 1606, e da Nova Zelândia, em 1642, pelo também explorador holandês Abel Tasman. Com a conquista das Américas no fim do século XV, pela frota liderada pelo navegador genovês Cristóvão Colombo, sob as ordens dos reis católicos da Espanha, verifica-se o aumento das práticas de exploração humana objetivando a maximização dos lucros. Assim, o acúmulo de capitais, fortalecimento da burguesia e mais tarde o uso de mão de obra assalariada substituindo o sistema de 
trocas, apontam para a consolidação de um sistema mercadológico mundial. A exploração europeia e a conquista de civilizações distantes reorganizaram o mapa global, a partir de novas divisões, contatos com fronteiras remotas, transmissão de doenças, animais, plantas, alimentos e culturas entre o Velho e o Novo Mundo. Sendo assim, a chamada "era dos descobrimentos" é considerada por muitos historiadores como um marco da passagem do feudalismo medieval para a Idade Moderna, principalmente pela ascensão dos estados-nação europeus e o estímulo à pesquisa científica. Os navegadores que ficaram mais conhecidos foram Cristóvão Colombo, Vasco da Gama, Pedro Álvares Cabral, Bartolomeu Dias, Américo Vespúcio, James Cook, Abel Tasman, Fernão de Magalhães (Boxer, 2002).

A alteração da ordem cultural vai se desenhando aos poucos e ganha maturidade no século XIX, com a solidificação da Revolução Industrial, iniciada na Inglaterra no século XVIII e espalhada pelo mundo a partir de então. O acúmulo de riquezas através da comercialização de especiarias e matérias-primas não provenientes do solo europeu perde força frente ao comércio de produtos industrializados pelas fábricas europeias. Com a rapidez dos processos produtivos, que muitas vezes substituíram o trabalho manual pelo maquinário, a margem de lucro dos donos de fábricas se multiplicou. O capitalismo ganhava nova dinâmica, com as máquinas a vapor chegando aos quatro cantos da Europa e expandindo de forma significativa a capacidade humana de transformar a natureza. A facilidade da produção ocasionou uma redução do preço das mercadorias e fez com que o mercado assumisse proporções significativas. No entanto, a classe operária do período enfrentou péssimas condições de trabalho, com baixos salários e constantes acidentes nas fábricas. Para Polanyi (2012 [1944]), o século XIX é singular para a história do mercado, pois apresenta uma mudança súbita dos pilares econômicos, derivados deste novo modelo de produção. Rosalind Williams (1982) caracteriza neste período os esforços pioneiros dos franceses no comércio varejista e na publicidade, e aponta a cidade de Paris como um grande arquétipo do consumo de massa. Williams (1982) sugere que as exposições da Cidade Luz de 1889 e 1900 trouxeram contribuições essenciais para as futuras lojas de departamentos e feiras de negócios.

A expansão do mercado também se dá com a exploração da Ásia e da África, no movimento conhecido como neocolonialismo ao longo do século XIX e início do século XX. Populações inteiras foram submetidas ao consumo dos 
produtos europeus, bem como tiveram seus materiais primários escamoteados. Aos poucos, o mercado vai tomando conta de todos os espaços disponíveis. Ele se torna a figura central que irá regular e atribuir sentidos ao sistema econômico capitalista, moldando não só as organizações e instituições sociais, como estabelecendo padrões para as composições identitárias. A institucionalização dos princípios capitalistas vai dar forma a uma economia de mercado que se fortalece e se mantém dinâmica e no controle até os dias atuais.

Promovendo um salto temporal até o fim do século XX constatamos que hoje o processo econômico se caracteriza por uma ênfase no mercado financeiro, a partir da prevalência do capital financeiro sobre o capital produtivo (Sodré, 2012). Para Sodré (2012), no mundo globalizado, o capitalismo financeiro está intimamente ligado à comunicação. A idolatria pelo espetáculo e pelos dispositivos técnicos levaram à "financeirização" como padrão de riqueza, sem maiores angústias psíquicas.

O capitalismo contemporâneo é ao mesmo tempo financeiro e midiático: financeirização e mídia são as duas faces de uma moeda chamada sociedade avançada, essa mesma a que se vem apondo o prefixo pós (pós-industrialismo, pós-modernidade etc.). Se antes a comunicação e a informação, sob a égide da sociedade produtivista, podiam ser analisadas como despesa extra do capital, hoje elas têm lugar de destaque no processo de unidade do conjunto, como biombo da financeirização, isto é, de um novo modo de ser da riqueza. No âmbito geral do neoliberalismo econômico, esse modo de ser é moldado por uma ideologia privatista, que elege como maiores valores sociais a eficácia produtiva e o sucesso pessoal. No plano da consciência individual, é uma ideologia de flexibilização, de abolição de qualquer suposta rigidez psíquica. (SODRÉ, 2012: 16)

O incremento tecnológico, dos meios de comunicação, dos transportes, a diminuição de barreiras geográficas e estatais entre os principais países do Ocidente permitiu que produtos fossem fabricados em maior escala, em diversas partes do mundo. Essa produção globalizada reduziu os custos, mas manteve a exploração de grandes segmentos populacionais localizados em países periféricos, sobretudo os do sudeste asiático, que sofrem com os baixíssimos salários e ausência de direitos trabalhistas. O International Labor Rights Forum ${ }^{14}$ (Fórum Internacional de Direitos do Trabalho) já denunciou uso de trabalho escravo por

${ }^{14}$ www.laborrights.org 
diversas empresas líderes de mercado, como a fabricante de artigos esportivos Nike e a marca de roupas de luxo, Burberry.

Com o aditamento da produção em massa e a dilatação do comércio desde o século XIX, nasce a necessidade de estabelecer diferenciação entre os produtores, o que dará origem à ideia de marca; e da necessidade de comunicar e informar às pessoas o valor de uso de um bem, surge a indústria publicitária. Demarcar os produtos com um símbolo, em geral um desenho e não uma palavra, aparece com a multiplicação das fábricas que abastecem diferentes mercados que não se identificam ${ }^{15}$. A produção já não é mais domínio do artesão que conhecia todos em uma comunidade e tinha seus produtos reconhecidos pelos clientes, sem a precisão da marca. Agora o rótulo vai trazer as informações que singularizam o produto dentro do vasto sistema industrial. A narrativa publicitária vai ser responsável por atribuir sentidos aos produtos indistintos, conferir alteridade, exaltar suas particularidades em relação aos demais, estabelecendo posições culturais. E através da publicidade, o consumidor pode então instituir suas preferências.

Os estudos de McKendrick, Brewer e Plumb (1982) apontam um desenvolvimento maior de técnicas de marketing desde meados do século XVIII, especialmente seu uso no campo da moda, com as revistas segmentadas, modelos de beleza e manequins que estabeleciam padrões estéticos corporais. O cidadão ocidental começava a viver em um clima estimulado artificialmente, que afastava seus gostos e preferências das referências da tradição e costumes locais para remanejá-lo entre as forças de mercado capitalistas. Em Dream Worlds: mass consumption in nineteenth century France, Williams (1982) descreve como a produção de bens de luxo foi deslocada do ambiente doméstico e privado para o domínio público de mercado. Na França, pós-Revolução Francesa, foi comum a migração de chefs de cozinha de hotéis da alta classe para os restaurantes populares, assim como costureiras e alfaiates acostumados a prestar serviços para a nobreza também transferiram-se para as lojas. A produção passa a direcionar sua atenção ao consumo público de mercado.

\footnotetext{
${ }^{15}$ Os publicitários costumam se lembrar de certos símbolos antigos como forma de mostrar a longevidade da profissão, tais como perucas para designar uma barbearia ou cabeça de boi para identificar um açougue. São referenciais evocativos que indicam uma procedência heroica para a profissão e não necessariamente uma forma de narrativa publicitária. Essa genealogia é um mecanismo de legitimação da profissão, como veremos adiante.
} 
O aparecimento da loja de departamento, também conhecido como grande armazém ou grande magazine, foi outro importante momento da dinâmica do mercado no século XIX. Reunir uma larga variedade de produtos agrupados em categorias em um ambiente de grandes proporções seduziu o consumidor. A primeira loja nestes moldes foi Le Bon Marché, surgida em Paris, no ano de 1852. $\mathrm{O}$ comerciante Aristide Boucicaut, junto à sua mulher Marguerite, transformou a pequena boutique que ficava às margens do Rio Sena em um grande centro comercial, onde os produtos passaram a ser distinguidos entre si pelas marcas dos seus fabricantes. O elegante prédio, projetado pelo arquiteto Louis-Charles Boileau, conseguiu reunir principalmente as mulheres em torno da moda, gastronomia, objetos de design, artigos de beleza e participou ativamente da vida cotidiana da capital francesa. Os catálogos do Bon Marché mostravam como se vestir, decorar a casa ou gastar o tempo livre. Eram fichários que tornavam certos valores manifestos mais evidentes nas vidas individuais (Miller, 1981).

O novo ambiente de compras era extravagante e envolvente, levava o consumidor a passear pelos itens em exposição e testar suas utilidades liberados de qualquer obrigação. A lógica do mercado baseado em transações por barganha de preços é irrompida por um modelo em que as tarifas eram fixas, a venda compulsória e a compra opcional. Possibilidade de troca de mercadorias, períodos de promoções para esvaziar os estoques, entrega de produtos em domicílio foram inovações trazidas pelas lojas de departamento (Rocha et al, 2016). Para estimular a aquisição de produtos, que algumas vezes estavam fora do poder aquisitivo dos consumidores, instituiu-se o sistema de crédito. A possibilidade de comprar em prestações, através de empréstimos impessoais deu ao consumo uma dimensão de sonho, tudo poderia estar ao alcance das mãos (Williams, 1982). A loja de departamento transformou definitivamente os padrões de gostos, preferências, as interações entre compradores e vendedores e as técnicas do mercado.

Esta nova instituição ajudou a mudar a natureza da estética pela qual os bens eram negociados, introduzindo técnicas poderosamente persuasivas no cinema e na decoração que ainda continuam a ser refinadas. A loja de departamento também mudou a natureza mesma do lugar no qual as pessoas consumiam, o que elas consumiam, a informação que precisavam para consumir e os estilos de vida aos quais esse novo consumo era devotado. Ajudou a criar o significado carregado pelos bens e mesmo a "reescrevê-lo" quando a mudança social assim o demandava. Finalmente, as lojas de departamento foram agentes de difusão, funcionando como vastas salas de aula nas quais os cidadãos do século XIX 
podiam aprender as artes e as habilidades de seu novo e vital papel como consumidores. (MCCRACKEN, 2003: 51)

$\mathrm{Na}$ Inglaterra, o comerciante norte-americano Gordon Selfridge batizou com seu nome uma das lojas de departamento mais importantes e conhecidas do mundo. Redigindo seus próprios anúncios publicitários para jornais, Selfridge conseguiu que sua magazine fosse considerada um espaço de lazer, bom gosto e entretenimento pela sociedade inglesa. A loja ganhou respeito e credibilidade, tornando-se referência de ambiente seguro e luxuoso, onde mulheres da alta sociedade podiam frequentar sem maiores preocupações (Rappaport, 2001).

O modelo da loja de departamentos rapidamente se espalhou para além do continente europeu. Em 1890, todas grandes cidades da América do Norte já possuíam esse tipo de comércio, precursor do shopping center (Tamilia, 2002). A fim de prolongar a permanência dos consumidores nesses ambientes, foram instalados restaurantes, bistrôs, banheiros sofisticados, apresentações de música ao vivo, pequenos concertos (Rocha et al, 2016). Renato Ortiz (2003) também destaca o papel educador das lojas de departamentos como instrutoras de um comportamento social que levava ao consumo, além de se projetarem como instâncias que ofereciam novos espaços de mobilidade e locomoção:

\footnotetext{
Projetadas especialmente pelos arquitetos, as lojas de departamentos eram concebidas como grandes espaços (são precursoras dos supermercados) no interior dos quais as pessoas poderiam se deslocar à vontade. Os produtos, agora administrados racionalmente, e expostos de maneira a deliberadamente estimular os desejos, favoreciam a circulação da mercadoria para as mãos do “consumidor". (ORTIZ, 2003: 48)
}

Neste sentido, temos desde o século XIX o consumo como um valor social permanente, como aponta McCracken (2003), uma vez que indivíduos e produtos foram intrinsecamente ligados em uma relação ativa a partir de então. Numerosos mecanismos aditaram valores culturais aos bens, através de sofisticadas técnicas de transferência de sentido. Mudanças sociais profundas acionaram novas e peremptórias formas de comunicação.

Portanto, somente com a solidificação da noção moderna de mercado, aliada à expansão midiática ocasionada com a formação da sociedade de massas, 
que a publicidade se estrutura com competências próprias, regras, posicionamentos, capitais, categorizações, concorrências, oposições efetivamente um campo, no sentido de Pierre Bourdieu (1983 [1976]). Na teoria proposta pelo sociólogo, o campo representa um espaço simbólico, ou um "poder simbólico", um palco de lutas para legitimar códigos e signos de pertencimento e adequação determinados pelos seus próprios agentes em conflito. As representações validadas pelos atores sociais vão deliberar rituais e valores planejados para cada estrutura dentro do campo, que possui lógicas e hierarquias próprias. A formação de um campo caracterizará a autonomia de certo domínio dentro do espaço social. É um instrumento de poder, no qual podemos analisar dominações e condutas particulares de um segmento social.

Dentro de cada campo existem as figuras de "autoridade", aquelas que acumulam maior volume de capital. O termo capital é usado em sua obra, não apenas no sentido econômico, de acúmulo de riquezas, mas também como um recurso ou poder que pode ser usado em uma atividade relacional na sociedade. Bourdieu (1983 [1976]) sugere a existência de um capital simbólico que vai além das questões econômicas, que a seu ver, apenas reduzem o espaço multidimensional do mundo social. O capital simbólico é aquele que irá estabelecer classificações de prestígio, reputação e honra, permitirá a identificação dos agentes em cada espaço. Para o capital simbólico ser reconhecido é preciso que o agente acumule capital cultural, através da conquista de saberes, títulos e diplomas, capital social, relações que podem ser convertidas em exercícios de poder, além do capital econômico, a soma de rendas, bens e salários. Podem existir ainda os capitais político, esportivo, artístico, dependendo das relações em disputa em cada espaço social. Embora o campo econômico tenda a impor sua estrutura sobre os demais, ele não é apenas o único responsável pelas questões que transformam o todo social. Bourdieu (1893 [1976]) aponta que as desigualdades sociais podem ocorrer, não somente pelos obstáculos econômicos, como também pelas disparidades no acesso aos bens culturais. Os diferentes tipos de capital irão funcionar como poderes que definem as chances de triunfo em um determinado campo. Para ocupar um espaço, os atores sociais precisam conhecer as regras do jogo dentro de seu campo, a fim de travar suas lutas e conquistas.

O domínio profissional da publicidade se desenvolveu em torno da estrutura das agências, instituições que concentraram e organizaram todas as 
faculdades para o exercício da publicidade e a concepção da profissão de publicitário. A publicidade, portanto, só encontrou as pré-condições de sua existência como um campo de atividades autônomo na estrutura social a partir da Revolução Industrial, processo histórico e cultural que se dissemina por todo o Ocidente, a partir de meados do século XVIII.

No caso do Brasil, o movimento de industrialização ganha amplitude e consistência na virada do século XIX para o século XX. Assim, quando Gilberto Freyre (2010 [1961]) estuda, de forma pioneira, as imagens e representações do escravo em anúncios de jornais, tais anúncios não se caracterizam como uma narrativa publicitária nos mesmos termos nos quais entendemos a atividade hoje. Os "reclames" analisados por Freyre eram, evidentemente, realizados fora das agências, pelos proprietários de terras, sem que nada pudesse indicar que eram produções próprias do campo da publicidade. Tornar uma mensagem pública não é sinônimo de atividade publicitária. Anunciar qualquer coisa é algo que sempre pode ter existido nas culturas humanas. Divulgar ou mesmo publicar em um veículo de comunicação uma mensagem, anúncio ou notícia não faz com que possamos entendê-los como publicidade.

Embora publicada apenas em 1961, a obra começou a ser escrita logo depois do lançamento de Casa Grande e Senzala, em 1933. O texto foi proferido pela primeira vez em uma conferência realizada no Rio de Janeiro, na Sociedade Felipe d'Oliveira, e publicado na revista Lanterna Verde. O caráter inovador do trabalho também se confirma pelo uso de jornais como fonte histórica. Até aquele momento, no Brasil, não existiam estudos que utilizavam a imprensa ou qualquer outro veículo de comunicação para interpretações sociológicas. Ao folhear os jornais do século XIX, Freyre compreendeu que aqueles anúncios ofereciam um excelente retrato das condições de vida no Brasil imperial. A utilização de anúncios como fonte de pesquisa também foi usada em Sobrados e Mucambos (2003 [1936]), onde Freyre analisa a decadência do patriarcado rural frente ao desenvolvimento urbano no fim do século XVIII e a primeira metade do século XIX. Anúncios de casas para aluguel e venda, oferta de empregos, porcelanas, louças, chapéus, sapatos, móveis, medicamentos, vestidos de noiva ajudaram a descrever os comportamentos nos meios urbanos e os processos de "europeização" do Rio de Janeiro. Freyre (2010 [1961]) criou o termo anunciologia para referir-se às manifestações sociais identificadas nos 
classificados de jornais.

Orgulho-me de, ainda muito jovem, ter-me antecipado nessa valorização de anúncios em jornal: começo no Brasil, de uma anunciologia. $\mathrm{O}$ anúncio, desde o seu aparecimento em jornal, começou a ser história social e, até, antropologia cultural, da mais exata, da mais idônea, da mais confiável. (FREYRE, 2010 [1961]: 21)

Em O escravo nos anúncios de jornais brasileiros do século XIX, Freyre (2010 [1961]) traça uma análise antropológica de escravos fugidos ou colocados à venda nos tempos do Império. A obra esboça um panorama da época, ao descrever com riqueza de detalhes a aparência física, comportamentos, habilidades, vestuário, castigos e relações mantidas com os senhores. Estes anúncios publicados nos jornais eram fonte de troca de informação para que os senhores das fazendas pudessem localizar seus escravos que haviam fugido e poderiam ser achados. Vender ou trocar empregados, escravos ou não, com outros fazendeiros também era o objetivo dos avisos nos jornais. Segundo a reflexão marxista (Marx, 1978 [1848], 1980 [1867]) não podemos dizer que o modo capitalista de produção estava embutido nestas relações entre senhores e escravos. Em termos gerais, o sistema capitalista determina que o trabalhador receba um salário em troca do seu trabalho; toda negociação é feita com dinheiro; as mercadorias são destinadas para venda; o capitalista pode admitir ou demitir os trabalhadores, já que é detentor dos meios de produção e do capital. Desta forma, as relações escravocratas praticadas no Império brasileiro não estariam encaixadas no modelo capitalista. Sendo assim, não poderíamos considerar aqueles anúncios do século XIX como uma atividade publicitária, pois não estariam presentes as precondições para sua realização, do mesmo modo em que é inexistente a presença de um mercado consumidor. Com o fim da escravidão, oficializada pela assinatura da Lei Áurea em 1888, e a instalação da República, temos o início da expansão da prática capitalista no Brasil, e o mercado começa a ser o grande regulador das ações humanas. É evidente que nessas observações não está em jogo, nem o mérito, nem a criatividade do estudo de Freyre (2010 [1961]) em utilizar esses materiais, apenas queremos enfatizar a diferença fundamental existente entre anúncios em toda e qualquer época e a atividade publicitária nascida a partir da modernidade e do capitalismo. 
Dentro desta acepção, procuramos sempre associar o conceito de publicidade às suas finalidades pecuniárias, caracterizadas pela relação com a economia capitalista. Como plataforma de veiculação, logo de materialização desenho, configuração das narrativas - consideramos que a publicidade demande meios que exportem essa forma de comunicação para alcances massivos. Por conseguinte, para termos publicidade é necessário também um universo midiático estruturado na vida social através de sistemas balizados pelo capitalismo. Assim, nos referimos à publicidade especificamente quando se trata de mensagens de divulgação de produtos e serviços, produzidas por agências de publicidade e difundidas nos meios de comunicação massivos em espaços pagos, veiculados sob a responsabilidade de um anunciante (via de regra, uma pessoa jurídica) conhecido.

Devido ao vínculo da publicidade com o universo financeiro, as práticas de mercado, o mundo dos negócios e os meios de comunicação de massa, ela foi objeto de certo preconceito e relativamente negligenciada pela academia. A produção publicitária era vista como engodo mercantil, um material que não merecia a atenção e seriedade das pesquisas. Como consequência, desenvolveu-se uma crítica contundente que desaprovava o estilo de vida capitalista e associava a publicidade aos intentos de manipulação e homogeneização da cultura nas chamadas sociedades de consumo (Adorno; Horkheimer, 1991 [1947]). A tradição da Escola de Frankfurt tentou entender a problemática dos meios pelo viés das indústrias culturais, perspectiva que Umberto Eco (1976) chamou de "apocalípticos". Nos processos de produção simbólica, a publicidade serviria apenas para estimular hábitos de consumo e padronizar a cultura. Tais visões se mostram parciais e incompletas ao isolar a publicidade de análises que possam discutir, não só as homogeneizações, como também as diferenciações, no domínio das práticas sociais, da formação dos significados em cada fluxo temporal e espacial, da composição das suscetibilidades individuais e distintivas procedentes da complexidade cultural. 


\section{2 - Transformações do novo século}

A virada para o século $\mathrm{XX}$ não foi uma passagem de ano qualquer no Brasil e no mundo. A celebração trazia a esperança de novos tempos aclamados pela ciência e tecnologia. A aura de modernidade se espalhava por todos os cantos, nunca tínhamos ido tão longe em termos de avanços técnicos. Um projeto de futuro era profetizado pelas máquinas que facilitavam a vida humana e o convívio harmônico com a natureza. A lâmpada elétrica, o telefone, a fotografia e o automóvel, descobertos no fim do século XIX, exerciam fascínio e estavam em largo desenvolvimento (Reis et al, 2008). Há pouco menos de cinco anos, no subterrâneo do Grand Café, em Paris, os irmãos Lumière encantaram o mundo com a primeira exibição pública de cinema. Aquela transposição de imagens paradas com efeito de movimento ludibriou os cérebros e transformou definitivamente a experiência pública.

As primeiras décadas do século XX aumentaram ainda mais a atmosfera entusiasta com as inovações da ciência. Em 1904, o cientista alemão Christian Hülsmeyer inventou o radar, primeiro dispositivo para detectar objetos a longas distâncias. Em 1906, Santos Dummont voou no 14 Bis, embora esse pioneirismo não tenha trazido reconhecimento internacional. Em 1915, Albert Einstein publicou a Teoria da Relatividade, o que ampliou as concepções astrofísicas da época, mas gerou polêmica entre os estudiosos. Em 1928, o médico Alexander Fleming descobriu a penicilina, um antibiótico natural que trouxe grandes contribuições, já que as doenças infecciosas de origem bacteriana afligiam as sociedades (Reis et al, 2008). A chamada "Linha de Produção", forma de ação encaixada e serial, popularizada em 1913 pelas linhas de montagem de Henry Ford, revolucionou a indústria com seu novo jeito de produzir. Ford organizou a produção em linhas contínuas que, divididas em partes, ampliaram os resultados em um espaço de tempo reduzido (Reis et al, 2008). Estava criado o modelo da fabricação em massa industrial, que transformou substancialmente a organização do trabalho e as relações humanas com artefatos materiais. A demanda amplificada da produção de bens viria atender aos novos anseios da sociedade moderna e já esboçava o consumo como fenômeno cultural. O padrão fordista simbolizou a superação de uma economia agrária em direção à expansão de um 
modelo industrial. A ideia de que o trabalho humano poderia ser substituído por máquinas redimensionou as relações entre capital e trabalho dali em diante (Marx, 1978 [1848], 1980 [1867]). A estrutura baseada no artífice, trabalhador único, inventor manual tem o peso diminuído, dando lugar a um processo de desumanização da esfera produtiva (Rocha, 1985).

Com o processo simbólico que determinamos chamar de Revolução Industrial - sobretudo com a chegada das máquinas elétricas e aprimoramento da imprensa nas últimas décadas do século XIX - podemos perceber uma transformação profunda nos modos de vida, especialmente na produção de expressões culturais. A noção de mercadoria é atrelada à produção do conhecimento, reforçando os modelos econômicos modernos. O quadro de modificações sociais decorrentes da industrialização, o novo modelo de produção, com ênfase no maquinário, representou praticamente o ocaso da sociedade agrícola. A atividade industrial passou a ocupar o centro da vida. A economia ganha relevância como a ciência que vai reger os comportamentos e espíritos. Formam-se grandes empresas industriais e o trabalho assalariado passa a predominar por toda a parte. A burguesia industrial se fortalece, bem como a classe operária começa a ganhar espaço no tecido social (Marx 1978 [1848], 1980 [1867]).

No Brasil, estávamos nos acostumando com a república recémproclamada. Para o mundo, ainda não passávamos de simples fornecedores de matéria-prima agrícola, sobretudo café e borracha. No entanto, o processo de transferência do poder político e econômico da elite agrícola-rural para uma burguesia urbana que começava a povoar as grandes cidades acenava para mudanças significativas em território nacional. O Rio de Janeiro, como sede do Governo Federal, estava entre os principais centros produtores de café do país. O café seria o produto-chave para um processo de expansão que atingiu São Paulo, parte da região Sul e do Centro-Oeste, incentivando, inclusive, negócios em torno da comunicação comercial como estratégia eficaz para estimular vendas. A borracha também se torna produto de grande importância, atingindo seu ápice em 1910, com 40.000 toneladas exportadas por ano (Martins Filho, 2011). A diversificação da economia, fortalecida também em setores como o têxtil, de alimentos e bebidas, gerou um prelúdio de anúncios e expressões de vendas. 
Naquele início de século, a ideia de propaganda ainda estava diretamente relacionada à comercialização de medicamentos. Nesse sentido, como foi dito, não podemos enquadrar nesta categoria as inúmeras atividades, como a compra e venda de escravos, transações imobiliárias, dentistas de plantão e serviços em geral que utilizavam classificados de jornais, única mídia comercial do período, para divulgar seus préstimos. A indústria farmacêutica era a maior anunciante até então, com suas estratégias populares. Dos cartazes em bondes aos primeiros anúncios de revistas, a promessa de cura sempre chamou atenção dos brasileiros e alavancou vendas naqueles tempos. Os propagandistas de remédios eram vendedores muito conhecidos, "homens-reclames" que articulavam a linguagem publicitária para levar as novidades da indústria farmacêutica à classe médica e ao conhecimento da população em geral, através de técnicas que incluíam pequenos folhetos distribuídos nos consultórios e nas ruas. A imagem do propagandista ficou muito popular por volta dos anos 1940 (Ramos; Marcondes, 1995). Até os anos 1980, muitos publicitários chegaram a ser confundidos com estes antigos propagandistas de remédios. Em entrevistas sobre aspectos da vida profissional dos publicitários, essa mistura parece "irritar" o grupo que deseja se definir como portador de diploma de curso superior, envolvido em uma atmosfera de sofisticação e prestígio (Rocha, 1985). A legitimação e o status mais alto do publicitário brasileiro se consolidam a partir de meados da década de 1960, com a maior expansão dos meios de comunicação, das agências, o incremento de tecnologias e o reconhecimento internacional.

Entre os propagandistas de medicamentos merece destaque o trabalho de João Lyra, personagem folclórico que viajava o país promovendo os produtos do laboratório Daud \& Laugnilla. O persistente "homem-reclame" foi um dos primeiros a perceber a potência da divulgação comercial. Lyra veiculava anúncios de seus produtos na mesma posição em várias edições de uma revista. O hábito constante e regular gerava uma sensação de familiaridade e segurança nos consumidores. Além disso, negociava espaços nos veículos das cidades por onde passava, criava eventos e performances para atrair a atenção dos editores locais e, assim, transformar suas marcas em notícia. O pioneirismo deste trabalho sinalizou para a importância da publicidade ser pensada como uma atividade organizada que programa meios simultaneamente e produz peças criativas de forma frequente. Lyra criou o "reclame yankee", em 1910. Nos moldes dos grandes 
painéis usados no exterior, o propagandista faturou a lateral do elegante Teatro São José, recém-inaugurado em São Paulo, e lá anunciou os efeitos do xarope Bromil, cujo slogan era "Cura a tosse em 24 horas" (RAMOS; MARCONDES, 1995: 25)

No mesmo período também vimos surgir as primeiras revistas ilustradas, responsáveis por influenciar comportamentos e criar modismos. As revistas trouxeram uma nova atmosfera para a imprensa do país, sem o ranço da luta política, ideologia de combate e informação opinativa que marcaram os jornais do século anterior. Portanto, “(...) se o Brasil demorou mais de 300 anos, desde a sua descoberta, para fazer a sua primeira revista, andou depressa nos últimos 180 anos." (CIVITA, 1990: 217). Novas técnicas de impressão inundaram os veículos de comunicação com imagens. Para o historiador Daniel Boorstin (1980), com a invasão de material visual sobre as sociedades, o pensamento corria o risco de se tornar puramente imagético, pensar apenas em termos de representação, cópia de objetos e pessoas. A abundância visual viria modelar parte substancial da atividade publicitária, uma vez que os meios de comunicação estavam delineando suas mensagens majoritariamente através dos apelos das imagens. Boorstin (1980) vai chamar essa transformação de Revolução Gráfica. Os textos da mídia encontram na mediação imagética uma forma de comunicação, que de tão eficiente, passa também a interceder sobre as relações entre os sujeitos, mudando as percepções sociais (Debord, 1997 [1967]).

Em 1860, o alemão Henrique Fleiuss foi o responsável por lançar a Semana Ilustrada, no Rio de Janeiro (Souza, 2004). Mas foi somente na virada do século, em 1900, que vimos surgir a Revista da Semana, primeira encadernação que privilegiava o uso de ilustrações como complemento ao texto e como forma de anunciar produtos. Logo depois vieram $O$ Malho, A Careta, FonFon, publicações editadas na então capital da República. Em São Paulo surgem Vida Paulista, Arara, Cri-Cri. Os anúncios eram muito bem elaborados e vinham em posições fixas, marcando a mistura de um estilo art-nouveau europeu com o tecnicismo americano. Como o valor das assinaturas era alto na primeira década do século, algumas revistas eram de luxo e destinadas à elite econômica. Com a entrada de verbas publicitárias, o negócio se tornou mais popular nas décadas seguintes. A caricatura também exerceu grande influência na imprensa daquele início de século, como indica Sodré (1986). Os políticos foram alvo de 
sátiras ilustradas e garotos-propaganda das marcas. Importantes nomes da literatura também participavam como colaboradores das revistas. Monteiro Lobato e Olavo Bilac se transformariam em importantes redatores de anúncios. Os homens das letras se fizeram de garotos-propaganda não apenas para "enobrecer" a linguagem dos anúncios, como também para complementar seus rendimentos. Para fazer uma quadrinha em um anúncio, os intelectuais ganhavam quase cinco por cento do salário pago por mês a um redator-chefe de um grande jornal e, aos poucos, foram percebendo o seu valor de mercado. Certa vez, Bilac recebeu a expressiva quantia de cem mil réis ${ }^{16}$ de uma fábrica de fósforos para escrever quatro versos: "Aviso a quem é fumante/ tanto príncipe de Gales/ Como Campos Salles/ Usam fósforos Brilhante". (SCHERER, 2012: 76). O poeta preferia a leitura dos anúncios à dos artigos de opinião, uma vez que considerava os espaços pagos fonte de estudos do pensamento popular (Scherer, 2012).

Os desenhos sofisticados de artistas como J. Carlos e K. Lixto abriram importantes espaços de possibilidades gráficas para a propaganda. O refinamento das mensagens também procurava marcar uma diferença em relação ao padrão tradicional consagrado pelos classificados de jornais. Como mais de dois terços da população brasileira eram de analfabetos até a década de 1920, as revistas tiveram papel determinante na ampliação da base informativa da sociedade, ao permitir uma "leitura" através das imagens. A cultura visual interferiu, não só na produção de significados decorrentes das novas interpretações, como também na composição de outros arranjos sociais. A renovação imagética da imprensa promoveu um diálogo entre a sociedade instruída e a iletrada (Bortoni-Ricardo et al, 2008).

Com os aparatos da indústria gráfica remodelando a imprensa tradicional, o consumo começa a ocupar lugar de destaque no cotidiano e a ser pensado como um fenômeno que espelha os estilos de vida da coletividade urbana em expansão. A ideologia do consumo irá penetrar profundamente nas sensibilidades, estabelecendo diretrizes para novos contornos da experiência pública e privada. Com a formação das metrópoles, grandes espaços de comunicação e troca se estabelecem, uma vez que o contato humano já pode extrapolar os limites das pequenas distâncias geográficas. Uma cena urbana complexa e contraditória vai

\footnotetext{
${ }^{16}$ De acordo com o conversor de valores do jornal $O$ Estado de S. Paulo, cem mil réis equivaleria a quatro mil reais. http://acervo.estadao.com.br
} 
marcar o nosso modelo civilizatório. O processo industrial instala uma ordenação nas cidades que em parte se sustenta nas relações de compra e venda. A etiqueta urbana irá abraçar o consumo como o elemento doutrinador dos comportamentos, estilos e modos de vida. Desta forma, o consumo vai ensinar, objetiva e subjetivamente, como vamos nos organizar nesta composição social moderna. Sendo assim, estas publicações ilustradas também se tornaram importantes referências deste novo estilo de vida que nascia nas capitais nacionais.

A arquitetura recortava a paisagem cosmopolita com vitrines ornamentadas que ostentavam produtos e marcas do mercado em franco crescimento. A imagem fora potencializada nos mais diferentes aspectos e setores. Na grande cidade, o sentido da visão prevalecia sobre a audição (Pais, 2010). A modernidade se associou à hegemonia do olhar. Os meios de comunicação asseguraram o vínculo com a representação da cidade, tanto no real, como no imaginário. A publicidade aproveitou o crescimento citadino para impetrar suas narrativas. Com a exportação de valores culturais massificados, a presentificação do tempo se tornou responsável por mudanças significativas nas relações humanas e impactou as subjetividades (Morin, 1989 [1962]). Para Guy Debord (1997 [1967]), o tempo se tornou um fator de abstração e, muitas vezes, esteve conectado ao tempo de consumo das imagens. O consumidor transportou-se à ficção das narrativas dos meios de comunicação, tornando-as reais através de identificações catalisadas pela imagem. De forma cada vez mais constante, a experiência urbana foi redimensionada pelos processos comunicacionais, e a comunicação verbal ultrapassada pela comunicação a distância (Canclini, 2005).

Com a organização industrial, a oferta de bens e serviços se multiplicou, promovendo um crescimento do comércio. O telefone, o telégrafo, o cinema, o automóvel, o avião, trens e estradas aproximaram as principais cidades do mundo e inspiraram outra percepção da realidade. Os fluídos modernizantes do velho continente geravam um clima de efervescência cultural neste lado do Atlântico. Paris era a referência para a moda e a elegância nacional, o grande centro produtor de códigos culturais com seus cafés, óperas, teatros, boulevards e alta costura. A literatura, que cultuava a boemia nos textos de Balzac, Baudelaire e Rimbaud, era a grande inspiração dos intelectuais brasileiros. Os periódicos ilustrados se tornaram o maior canal de consumo dos modelos franceses retratados através da crônica social, da charge, sonetos e fotos de pessoas (Siciliano, 2014). 
Pianos, automóveis, perfumes, carros de turismo passam a ser anunciados nas páginas de revistas. As importações começam a gerar um lucrativo comércio, com as mercadorias vindas de navio da Europa e dos Estados Unidos. O apreço e a imitação das vanguardas europeias determinaram as principais escolhas de consumo da sociedade brasileira. O chapéu, por exemplo, se tornou artigo obrigatório no vestuário de homens e mulheres. Mais de 1 milhão e 400 mil unidades foram produzidos pela indústria chapeleira nacional em 1905. Entretanto, segundo o vendedor Antonio Francisco Bandeira Junior, os consumidores não podiam saber que o produto era feito no país. "Se o comprador souber que o chapéu é nacional, embora lhe custe $60 \%$ menos, não o quererá!" (ABRIL CULTURAL, 1980:13).

Vivíamos sob forte influência do icônico período conhecido como BelleÉpoque, que compreende a expansão da cultura cosmopolita europeia desde o meados do século XIX até a eclosão da Primeira Guerra Mundial, em 1914 (Siciliano, 2014). O clima intelectual e artístico dessa época, marcada pela intensa produção cultural, inovações científicas e paz entre os países produziram transformações traduzidas como novos estilos de vida e modos de pensar (Scherer, 2012). O fascínio exercido pelos cabarés foi determinante para dar prestígio social à cultura da diversão, uma vez que nestes recintos era possível encontrar uma mistura de elementos da cultura das classes baixas com a cultura erudita.

A eclosão da Primeira Grande Guerra viria abafar e suspender a euforia cultural dos tempos de Belle-Époque. O mundo embarca em um novo tempo marcado pelo horror dos conflitos armados ao custo de inúmeras vidas humanas.

\section{3 - Novas perspectivas sociais e políticas}

A Primeira Guerra Mundial trouxe profundas mudanças que reorganizaram o mapa político europeu e provocaram o nascimento de um novo panorama social. Não por acaso é nesse contexto que surge a primeira agência de 
publicidade no Brasil, a Eclética. Na história da publicidade, 1914 é mais que uma efeméride histórica, é um ponto-chave para o estudo da comunicação.

A participação brasileira no conflito, chamado popularmente de "Guerra de 14", foi pequena. Sob comando do presidente Venceslau Brás, e forte pressão popular, declaramos guerra aos Impérios Centrais ${ }^{17}$ no dia 26 de outubro de 1917, após um cargueiro nacional ter sido torpedeado por um submarino alemão, perto da costa da Espanha. Àquela altura outras embarcações brasileiras já tinham sido alvos de ataques. A Guerra evidenciou a liderança de políticos como Rui Barbosa, que agitava comícios a favor dos Aliados com o propósito de finalizar o embate. A falta de estrutura militar e os problemas internos do país resumiram a participação do Brasil ao envio de um grupo de aviadores do Exército e da Marinha que foram integrados à Força Aérea Real Britânica, em 1918, e médicosmilitares do Exército incorporados ao Exército Francês. A contribuição militar da Marinha foi mais expressiva, com a missão de monitorar a costa noroeste da África a partir de Dakar, e o Mediterrâneo, desde o estreito de Gibraltar (Monteiro, 2014b).

A perturbação do comércio internacional provocou efeitos diretos na economia brasileira. Com receio da dependência externa, o país passou a investir pesado na política de industrialização, e na exportação de gêneros alimentícios e matérias-primas. Neste período, são fundados mais de seis mil estabelecimentos fabris, como efeito da dificuldade de se obter manufaturas do exterior (Martins Filho, 2011).

O historiador inglês Eric Hobsbawm, em seu livro A era dos extremos: o breve século $X X$ (Hobsbawm, 1994), considera que a história do século XX foi edificada nas bases catastróficas das trincheiras das guerras. O ano de 1914 representa um marco inicial para interpretar as transformações seguintes que moldaram a política, a economia, os comportamentos sociais, a cultura e os afetos individuais. Para o autor, a Primeira e a Segunda Guerra e o surgimento da União Soviética, como alternativa ao capitalismo, marcam a primeira fase do século XX - de 1914 a 1948. Depois de duas grandes guerras e uma quantidade de mortes humanas assustadora, novas sensibilidades e maneiras de se relacionar foram

${ }^{17}$ Os Impérios Centrais, originalmente chamados de Tríplice Aliança, eram formados pelos Impérios Alemão, Austro-Húngaro e Italiano. Contudo, a Itália acabou lutando do lado dos Aliados, com base na Tríplice Entente composta por Reino Unido, França e Império Russo (Monteiro, 2014b). 
desenvolvidas. Rocha e Pereira (2009) mostram que foi a partir da Primeira Guerra Mundial que a categoria de juventude passou a ser percebida e relevante nas civilizações ocidentais. Com a imensa quantidade de jovens vidas perdidas nas frentes de batalha foi preciso reconfigurar culturalmente essa noção perante os demais segmentos, para que a engrenagem social não parasse de funcionar. A concepção de jovem foi então expandida, achatando a infância e a maturidade. Esse entendimento, surgido em meio a uma falta, se consolidou como um dos referenciais mais fortes da narrativa publicitária, trabalhado de forma mais intensa pelas agências após a Segunda Guerra.

Hobsbawm (1994) coloca ainda que a partir da experiência de destruição causada pelas bombas atômicas nas cidades de Hiroshima e Nagasaki, no Japão, em 1945, emerge uma nova percepção da história. O mundo sai de uma perspectiva de sucessão linear, calcada na ideia de progresso, de futuro onipotente, para a ampliação do presente, inserindo-nos em uma presentificação ininterrupta do tempo. A bomba trará a intuição de que o futuro não é providente e pode ser muito cruel. Até aquele momento, o século XX já tinha acumulado mais mortes do que qualquer outro período histórico. Começa-se travar outra relação com o tempo, um crescimento da ideia de que o presente é a única temporalidade que vale a pena ser vivida. $O$ futuro pode não existir.

\begin{abstract}
Gerações inteiras se criaram à sombra de batalhas nucleares globais que, acreditava-se firmemente, podiam estourar a qualquer momento, e devastar a humanidade. Na verdade, mesmo os que não acreditavam que qualquer um dos lados pretendia atacar o outro achavam difícil não ser pessimistas, pois a Lei de Murphy é uma das mais poderosas generalizações sobre as questões humanas ("Se algo pode dar errado, mais cedo ou mais tarde vai dar"). À medida que o tempo passava, mais e mais coisas podiam dar errado, política e tecnologicamente, num confronto nuclear permanente baseado na suposição de que só o medo da "destruição mútua inevitável" (adequadamente expresso na sigla MAD, das iniciais da expressão em inglês - mutually assured destruction) impediria um lado ou outro de dar o sempre pronto sinal para o planejado suicídio da civilização. Não aconteceu, mas por cerca de quarenta anos pareceu uma possibilidade diária. (HOBSBAWM, 1994:224).
\end{abstract}

Diante da ideia da iminência da morte, o presente foi reforçado como um valor marcante na construção das sensibilidades. A valorização do presente como código cultural fortalecia também a consolidação da cultura de massas, que se expandia cada vez mais como uma doutrina planetária. "A Cultura de Massas 
privilegia o presente em uma imensa extensão que desposa e estimula a atualidade.” (MORIN, 1989 [1962]: 184). Mensagens fundamentadas na publicidade, que exportavam modelos de juventude, beleza, celebridades, práticas de lazer e consumo se espalhavam rapidamente e modificavam os estilos de vida em todo o Ocidente. A renovação dos modismos e das mensagens comunicacionais promovem uma atualidade eterna e cambiante, onde opera-se um fluxo incessante de esvaziamentos e uma busca constante da felicidade. O tempo se torna flutuante, tudo se substitui muito depressa com a perpétua incitação ao consumo.

Com a emergência da sociedade industrial, o avanço do conhecimento científico desde o fim do século XIX, a multiplicação das cidades neste início do século XX, o consumo é endossado socialmente como um grande enunciado para determinar a distinção social. Com a perda da dimensão humana do espaço da produção (Marx, 1978 [1848], 1980 [1867]), agora caracterizado pelo automatismo tecnológico dos processos industriais, este valor se transfere para o polo oposto, o do consumo, palco das emoções, identificações, usos e satisfações (Rocha, 1985). Dentro da cultura de massas, o consumo é associado ao espaço do lazer e ao desenvolvimento do prazer, da diversão, da felicidade moderna.

Embora, o caráter sanguinário das duas grandes guerras vá marcar a primeira metade do século XX, o desenvolvimento e expansão da indústria cultural (Adorno; Horkheimer, 1991 [1947]) caminhou paralelamente às atrocidades dos campos de batalha. Por volta de 1930, especialmente nos Estados Unidos, o cinema e o rádio começam a oferecer esta cultura que pretende atingir a todas as classes, independente das diferenças de riqueza, escolaridade, gênero, religião.

O universo de produções simbólicas da indústria cultural envolveu, encantou, seduziu, de forma tão contundente o mundo ocidental que seus produtos se tornaram uma espécie de espelho através do qual podemos assistir e procurar entender diferentes aspectos da vida moderno-contemporânea. Para Neal Gabler (1999), o entretenimento propagado pela cultura de massas se tornou uma força tão poderosa que acabou se fundindo com a própria vida. A ideia de que o entretenimento não exigia nenhum esforço mental para ser contemplado também foi usado como argumento para tentar explicar a primazia desse artifício sobre as massas (Chauí, 2006). O entretenimento provocava reações ligadas à noção de 
prazer, respondia apenas à lógica das sensações. Desta forma, a estratégia do entretenimento acoplado às produções culturais emergentes buscava um consumo baseado na função de lazer.

Essa indústria que espalhava diversão por todos os cantos também foi fomentada pela diminuição gradativa da jornada de trabalho. Ao longo de todo o processo de industrialização, essa foi uma reivindicação constante em muitos países. No início do século XX, o Brasil ainda seguia o modelo da Inglaterra na época da Revolução Industrial, com jornadas de doze horas diárias, totalizando até 3.600 horas por ano. Em geral, as jornadas eram fixadas de acordo com a vontade dos empregadores. Somente a partir da década de 1920 que se consolida a exigência dos "três oitos": oito horas de trabalho, oito horas de lazer e oito horas de descanso ${ }^{18}$. Em 1919, a Organização Internacional do Trabalho limitou a jornada diária de trabalho no setor industrial para oito horas e a semanal para 48 horas. Essa convenção foi adotada por 52 países, entre eles França, Bélgica, Canadá, Chile, Bolívia, Argentina. Mesmo com o padrão imposto pela OIT, algumas empresas francesas e norte-americanas chegaram a reduzir a carga horária de trabalho para 40 horas semanais. Com mais horas livres para o lazer, os parques, o cinema e, mais tarde, o rádio e a televisão se tornaram divertimentos de massa que provocavam um desprendimento momentâneo da realidade. O entretenimento era considerado como parte do ciclo de reposição de forças corporais e psíquicas e parte fundamental também do sistema de consumo (Morin, 1989 [1962]).

Desta forma, os conteúdos transmitidos pelos meios de comunicação se tornam importantes sustentáculos da estrutura capitalista presente nas grandes metrópoles (Morin, 1989 [1962]). A perspectiva de transformar bens culturais em mercadorias destinadas ao consumo e o controle ideológico das massas convertidas em "audiências" pelas classes dominantes foi duramente criticada pelos intelectuais da Escola de Frankfurt. Este pensamento, que nasce diante das tensões políticas europeias das décadas de 1930 e 1940, considera a indústria cultural um enorme risco às sociedades, uma vez que ela vai padronizar a fruição dos produtos culturais através de seu sistema simbólico sedutor. Tal mecanismo

\footnotetext{
${ }^{18}$ International Labour Organization. Convention 1, 1919. Padroniza a jornada de trabalho diária em 8 horas e a semanal em 48 horas. As informações que seguem no parágrafo estão contidas no mesmo documento. Disponível em: 〈http://www.ilo.org/ilolex/english/convdisp1.htm>
} 
de persuasão subjetiva através dos meios de comunicação, que se espalhavam pouco a pouco por todo o planeta, estaria destituindo a capacidade crítica das populações e abafando a ação política (Adorno; Horkheimer, 1991 [1947]).

Para fugir da violência dos regimes totalitários europeus, importantes pensadores, entre eles Theodor Adorno, Max Horkheimer e Herbert Marcuse, migram para os Estados Unidos. Walter Benjamin, um dos maiores expoentes da filosofia frankfurtiana, se suicida em 1940 durante uma tentativa de fuga pela fronteira da França com a Espanha.

Nos Estados Unidos, o American Way of Life, o estilo de vida americano, propagava os prazeres da cultura que vendia diversão. Produzida segundo as normas da fabricação industrial, a cultura de massas constitui um corpo de símbolos, mitos e imagens referentes à vida prática e à vida mental, um sistema de projeções e de identificações características que buscam o maior potencial de consumo (Morin, 1989 [1962]). Segundo essa crítica, na cultura de massas não há descontinuidade entre a arte e a vida, as barreiras que delimitam os aspectos ficcionais e reais começam a ceder. A cultura de massas acrescentar-se-á às culturas nacionais, humanistas e religiosas, sem entrar em competição com as doutrinas já existentes. No entanto, ela irá conseguir submeter os elementos dessas culturas às normas da indústria cultural (Morin, 1989 [1962]).

Deste modo, a compreensão da cultura moderno-contemporânea passa, de algum modo, pelo desvelamento dos conteúdos transmitidos pelos meios de comunicação, uma vez que suas narrativas se firmam como modos de estabelecer relações com o mundo, modificando não só as sociabilidades, como elaborando também novas formas de subjetividade. Para incitar desejos de consumo e desenvolver no imaginário coletivo os temas da cultura de massas, a publicidade se firma como o grande pilar por trás das mensagens comunicacionais. A publicidade é onipresente na cultura de massas, é um de seus prolongamentos práticos, ela vende a ideologia projetada pela indústria cultural. "Ela não empacotava produtos, mas sonhos. Na sua linha de produção não havia aço, comida em lata ou detergente, mas ícones, símbolos e significados." (ABAP, 2005: 19). A indústria publicitária maneja os signos e transforma as necessidades humanas. Os bens materiais cessam de ser utensílio de conforto e se tornam elementos de prestígio e status. Através da adesão do consumidor ao seu discurso, a narrativa publicitária criará cada vez mais enunciados persuasivos que não estão 
conectados com a noção de verdade utilitária ou valor de uso de um objeto, e sim com a realidade do signo profético que emite. O objeto passa a ser o "pseudoacontecimento" que se torna acontecimento real da vida cotidiana através dos sentidos simbólicos (BAUDRILLARD, 2010 [1970]: 163). Consumir se torna um ato de compartilhamento de sentidos, um rito que elabora formas de comportamento e ação social, e distribui os indivíduos em castas ou segmentos discriminatórios.

A escolha dos bens cria continuamente certos padrões de discriminação, superando ou reforçando outros. Os bens são, portanto, a parte visível da cultura. São arranjados em perspectivas ou hierarquias que podem dar espaço para a variedade total de discriminações de que a mente humana é capaz (...) O consumo usa bens para tornar firme e visível um conjunto particular de julgamentos nos processos fluidos de classificar pessoas e eventos (...) O indivíduo usa o consumo para dizer alguma coisa sobre si mesmo, sua família, sua localidade, seja na cidade ou no campo, nas férias ou na cidade (...) O consumo é um processo ativo em que todas as categorias sociais estão sendo continuamente redefinidas. (DOUGLAS; ISHERWOOD, 2004 [1979]: 114-116)

A narrativa publicitária será o grande "elo" que atribuirá significados entre a produção impessoal e o consumo. A publicidade será a ponte entre estas duas esferas e seus significados depositados no plano social (Rocha, 1985). Assim, o consumo ganha espaço na vida moderno-contemporânea como o processo de troca simbólica em que as identidades dos produtos, embutidas de representações orquestradas pela narrativa publicitária, se transferem para as identidades dos consumidores. O domínio da produção precisa ser nomeado, categorizado, objetivado dentro de um contexto cultural, a fim de que existam motivos para que o consumo se realize. À publicidade será atribuído este papel classificatório. É a partir dos sistemas discriminatórios construídos e negociados em cada grupo social que as visões de mundo e os estilos de vida são edificados.

Portanto, 1914 se põe como um importante referencial para a compreensão da era moderna uma vez que, a partir da Primeira Guerra e do crescimento da cultura do consumo, começa a emergir a percepção de que a produção simbólica poderia ser um valioso instrumento de dominação das massas. O fascínio e adoração exercidos pelo simbolismo da indústria cultural irão direcionar pensamentos, forjar identidades e compor estilos de vida. 
Não à toa, um importante personagem deste momento histórico passa a utilizar os meios de comunicação como poderosos instrumentos para a proliferação de uma ideologia. Nas décadas de 1930 e 1940, Adolf Hitler investe na construção de discursos elaborados, sedutores, romanceados. Tais narrativas simbólicas foram elementos cruciais para a implementação das políticas nazistas, principalmente a sustentação da guerra e o extermínio de milhões de pessoas com o holocausto. Algumas conotações pejorativas associadas ao termo "propaganda" são oriundas justamente desta ligação com a propaganda nazista e sua abundante aplicação durante todo o período hitlerista. Quando chegou ao poder em 1933, Hitler criou o Ministério da Propaganda, comandado por Joseph Goebbels. Técnicas de persuasão foram cientificamente planejadas para influenciar a opinião pública. Os objetivos do Ministério eram garantir a expansão da mensagem nazista através da arte, teatro, cinema, literatura, música, rádio e imprensa. O hábil orador Goebbels, que também foi cineasta, jornalista e filósofo, queria assegurar que nenhum cidadão na Alemanha tivesse acesso ou consumisse ideias contrárias ao Partido Nazista. Para isso, censurou toda a imprensa alemã, fechou jornais, editoras, rádios e emissoras de televisão. Em Berlim, o ministro da propaganda passa a editar o jornal Der Angriff (O Ataque), onde veiculava ataques e difamações antissemitas. Produzia filmes em que mostrava uma Alemanha próspera e feliz com a supremacia ariana (Longerich, 2014). Estímulo ao preconceito racial, patriotismo exacerbado, xenofobia eram temas das películas e propagandas que sempre condenavam os judeus, sob a alegação de que eram culpados por acumular riquezas e explorar a nação alemã. Foi Goebbels quem cunhou a saudação cinematográfica: Heil Hitler - Ave Hitler ou Vida Longa a Hitler. O führer (em alemão: guia, chefe, líder) se destacava por seus discursos enfáticos, com cenários, postura, entonação, luz, figurinos meticulosamente orquestrados para causar a maior impressão de poder possível. O estilo é até hoje usado por políticos, profissionais da propaganda e palestrantes (Longerich, 2014). 


\section{4 - O sistema de classificação publicitário}

Para pensar a publicidade como um dispositivo que articula importantes significados culturais no mundo moderno-contemporâneo é preciso refletir sobre a forma como suas classificações são acionadas. As sociedades têm o exercício da classificação como uma prática central na elaboração da ordem cultural ao estabelecer significados e, através deles, entender o mundo ao redor. Foi LéviStrauss (1975 [1962]; 2012 [1962]) em dois textos clássicos sobre o totemismo Totemismo hoje e O pensamento selvagem - ambos publicados em 1962, que trouxe a questão das classificações para o centro dos debates na Antropologia. Neles, Lévi-Strauss interpreta o totemismo, indicando que este é, sobretudo, um sistema de classificação que articula diferenças e semelhanças entre natureza e cultura. Nestes textos escreveu duas frases que viraram epígrafes especialmente conhecidas. Uma - "classifica-se como pode, mas classifica-se" - foi escrita em $O$ pensamento selvagem, e revela o desejo humano de classificar a qualquer preço, procurando juntar coisas, combinar peças, articular diferenças, dentro do princípio lógico, cuja regra é sempre poder opor termos, relacioná-los. A outra - "as espécies naturais não são escolhidas por serem boas para comer, mas por serem boas para pensar" - foi escrita em Totemismo hoje, e sublinha o aspecto simbólico do mundo natural, indicando que fazemos a passagem da matéria inerte para a cultura material. Os sistemas totêmicos tiram seu valor operatório do caráter formal que possuem: são códigos que levam e trazem mensagens entre séries distintas. Para Lévi-Strauss (2012 [1962]) a noção de natureza é relativa, é culturalmente definida. As concepções culturais da natureza, por sua vez, compartilham um traço comum: são o espaço de onde a dimensão humana se perdeu e, em certo sentido, a "natureza" é o "outro".

Um possível paralelismo entre natureza/cultura e produção/consumo foi elaborado no livro Magia e capitalismo (Rocha, 1985), no qual é discutida a possibilidade de que na sociedade moderno-contemporânea o lugar de sistema totêmico - código que converte mensagens entre natureza e cultura - é ocupado pela mídia e, particularmente, pela publicidade, que converte as mensagens entre produção e consumo. Assim, a esfera da produção precisa ser revestida dos 
símbolos que vão lhe dar sentido. E o consumo é a arena onde, efetivamente, este sentido ocorre. A produção é algo que só adquire lugar social quando impregnada de significado. Ela, como processo de transformação da natureza, só alcança seu destino de ser consumida - sem o qual não precisaria existir - através da construção de significados que humanizam produtos e serviços. A esfera da produção, sem atribuição de significado, é a esfera da falta que separa as palavras (significado) e as coisas (produtos e serviços). Introduzir o significado na esfera da produção quer dizer criar um código que faz daí nascer o consumo. A produção em si mesma não é nada, não "diz" nada. Em certo sentido, como lembra Marshall Sahlins (1979), uma casa vazia não seria uma casa.

Assim, todo e cada resultado da ação produtiva industrial é revestido de símbolos que se articulam em um código que completa produtos e serviços, dotando-os de sentido, sob a forma de usos, razões, desejos, instintos ou necessidades. A produção só cumpre seu destino de ser consumo através de um sistema que lhe atribui significação, permitindo participar de um idioma e ser expressão em uma linguagem. Na sociedade moderno-contemporânea, o consumo é, portanto, o sistema que classifica bens e identidades, coisas e pessoas, diferenças e semelhanças na vida social contemporânea. Por isso dizemos que produtos e serviços falam entre si, falam conosco e falam sobre nós - a decoração "fala" das casas, a roupa "explica" estilos e personalidades. Bens de consumo expressam nosso lugar na sociedade, quem é próximo ou distante, expressam nossos "interiores", sentimentos ou desejos e, no mesmo processo, expressam as relações dos próprios bens entre si. Por isso as ideias tão corriqueiras de que tal roupa pode ser a "cara" de alguém, tal carro revela "alto status" ou de que tal mesa de centro "combina" com o sofá da sala.

Neste sentido, a publicidade, através de suas narrativas midiáticas que invadem o cotidiano de forma tão trivial, elabora classificações, institui diferenças e semelhanças, bem como torna possível organizar a cultura material em posições definidas, articuladas e hierárquicas. É através de oposições entre os elementos componentes desse mundo dos bens que representações sociais são balizadas, o imaginário ganha sustentação concreta e as efetivas relações de vida entre atores sociais acontecem.

Nas sociedades de consumo moderno-contemporâneas, os objetos e a circulação de mensagens publicitárias são um excelente suporte para articular 
trocas entre as pessoas, instalar vínculos, agrupar semelhanças, construir diferenças, produzindo e mantendo códigos de relacionamento. Neste sentido, podemos dizer que toda cultura material guarda uma informação, possui um significado, ao mesmo tempo em que é uma plataforma que carrega esses significados para diferentes lugares e os elabora como experiências múltiplas. Em nossa vida social, o mundo dos bens marca identidades, explicita opiniões, organiza regras de troca, doutrina uma etiqueta para o corpo, desenvolve afetos. Parafraseando Lévi-Strauss, pode-se dizer que “(...) as espécies de nossa produção são boas para pensar." (ROCHA, 1985: 156), sintetizando a complexidade da relação sujeito-objeto em nosso mundo. Portanto, a forma como acomodamos e nos adequamos aos produtos e serviços é determinante para a compreensão da nossa experiência. Se os padrões de consumo podem revelar lugares de inserção social, a relação com os objetos é central para a construção das subjetividades. Numa cultura em que o consumo batiza, nomeia nossa singularidade histórica como "sociedade de consumo", a reflexão sobre afinidades entre indivíduos e materialidades indica uma perspectiva interessante para entender aspectos da trama social.

A ordem moderno-contemporânea atualiza, mais do que qualquer outra temporalidade, o cruzamento das relações entre homens e artefatos na construção das identidades. Os objetos contam as histórias de vida, são itens que podem servir como arquivos que conservam, inscrevem o valor memorial das experiências do passado, assim como também projetam sentidos para os valores que queremos instituir no futuro, os tipos de pessoas que pretendemos nos tornar e a imagem social que desejamos atingir (McCracken, 2003). Objetos celebram datas especiais como nascimentos, casamentos, formaturas, aniversários. Em geral, momentos importantes das nossas trajetórias pessoais e profissionais são marcados por rituais e adornados por objetos comemorativos, símbolos de determinada passagem. Assim, a aliança demonstra que alguém é casado, o diploma enrolado em um canudo atesta que o estudante completou sua formação universitária, o brinquedo parabeniza a criança que acabou de completar mais um ano de vida.

A presença de artefatos materiais sustentando a prática do ritual em nossa sociedade afirma o consumo como dispositivo articulador de vínculos de sentido entre objetos e sujeitos, além de ressaltar as dinâmicas interacionais que se dão 
entre cultura material e construção das subjetividades. Todos os grupos sociais possuem eventos que são considerados singulares, únicos, escapam à rotina e marcam momentos especiais das trajetórias de vida. Podem ser ocasiões festivas, religiosas, profanas, formais, informais. Nas sociedades exóticas ou tribais, como mostra DaMatta (2011), os elementos mágicos ou religiosos são usados como os principais articuladores de sentidos, associando os rituais à esfera do sagrado que rege a vida simbólica e organiza a experiência coletiva nestas culturas. Logo, podemos dizer que o ritual tem uma dimensão transformadora da experiência humana. "Os rituais concedem autoridade e legitimidade quando estruturam e organizam as posições de certas pessoas, os papéis mais ou menos claros, os valores morais e éticos e as visões de mundo.” (TRINDADE; PEREZ, 2014:159).

Os ritos exprimem o aspecto intangível das relações. Por meio da vivência repetida, a ritualização oferece segurança e tranquilidade emocional a um grupo. A formalidade e a repetição são características que definem a experiência do ritual, conhecemos a sequência das ações, suas etapas e encadeamentos, o que ajuda a desenvolver um senso de pertencimento à nossa coletividade. A ordem e a tradição inspira a perpetuação daqueles valores grupais para as gerações futuras.

Trocas de objetos, relações de posse, usos e desinteresses de produtos são processos rituais. As transferências de significados dos valores sociais para os bens e dos bens para os sujeitos vão balizar as práticas rituais na sociedade de consumo. Portanto, o ritual é um sistema cultural de comunicação que pode ser exercido através da publicidade. O discurso interno ao anúncio vai destacar certos elementos da realidade, rearranjá-los e combiná-los de uma forma particular, como no rito. $\mathrm{O}$ ato da compra subentende a transposição de uma coisa à outra, logo do encontro do sujeito com o mundo do anúncio e o deslocamento do significado do produto para a identidade do sujeito. Como num conto de fadas, onde a Gata Borralheira é transformada em Cinderela, o consumo transformará a subjetividade humana em um passe de mágica.

McKendrick, Brewer e Plumb (1982) observaram que, no desenvolvimento moderno, a ligação entre os jovens e os objetos que compunham suas identidades mudou. As novas gerações não estão mais interessadas em herdar artigos de seus antepassados. As posses que ostentavam certos significados sobre linhagem familiar, estirpes ou valores memoriais perderam apelo frente à rotatividade do consumo e aos mecanismos de persuasão contemporâneos, entre 
eles a publicidade. A partir do século XVIII, a família tornou-se menos disposta a herdar e mais propensa a comprar novos itens, escolher novas insígnias de distinção. A organização familiar seleciona entre a pluralidade de produtos disponíveis aqueles que apresentam um conjunto de signos que a representem socialmente. A cada nova mudança, um novo significado surge, um novo status, um novo senso de pertencimento. Também vemos um enfraquecimento da instituição coletiva diante do individualismo crescente. Desta forma, os indivíduos, mais autônomos do sentido de coletividade familiar, são impelidos a comprar de forma continuada, e a cada movimento de compra há uma ressignificação do conceito de si. As razões coletivas pelas quais viver se enfraquecem e emerge uma valorização excessiva do indivíduo, em que o consumo dirigirá boa parte das relações.

O consumo rotativo, efêmero do mundo contemporâneo amplia a margem de possibilidades para a constituição e manutenção das identidades. As conexões com as gerações anteriores são diminuídas diante da vinculação crescente com o mundo do consumo e das livres possibilidades de escolha. As identidades são refletidas como quadros inteiramente em branco, em que os indivíduos podem preencher com os conteúdos que desejarem, apagá-los e reescrevê-los novamente. Os objetos têm um papel-chave nesta escrita do self, nesta gama de definições para as identidades sociais.

\begin{abstract}
Para o velho sistema da família e da herança, o movimento dos bens de uma geração para a seguinte constituía um importante método de preservação da corporação, garantindo sua continuidade, retransmitindo seus valores, e trazendo para dentro da linhagem cada uma das sucessivas gerações. (...) Para o novo sistema, os bens são igualmente importantes. Constituem uma das fontes às quais a família e seus indivíduos recorrem a fim de obter um significado que não mais lhes é legado pela linhagem. Tais bens são úteis desta forma somente porque são produtos de um sistema gerador de significado e porque são perpetuamente revistos por novas circunstâncias sociais. A grande e geral aceitação de seu significado os torna praticamente inúteis para as gerações sucessivas. (MCCRACKEN, 2003:77-78).
\end{abstract}

Conduzida por novos gostos e opções, as gerações correntes se entregam ao processo sucessivo de aquisição de bens e mercadorias na cultura de consumo. O desprendimento dos valores em torno da família rumo a uma individualização de corpos é um fator significativo para o incremento do consumo moderno. O 
individualismo é um dos eixos de sustentação do sistema capitalista. O conceito ocidental de "pessoa", como coloca McCracken (2003), foi um dos grandes desdobramentos de nossa cultura, uma vez que mudamos a unidade de consumo, substituindo o núcleo familiar pelo individual. O sujeito independente é convertido em consumidor apto a fazer suas escolhas do modo que bem entender. As necessidades de consumo conspícuo se tornam mais imediatas neste mundo individualizado e não dependem do status acumulado pelo clã familiar. A competição social será um grande motor que irá fomentar a publicidade e ampliar as demandas de tempo dedicadas ao consumo. Uma quantidade expressiva de informação será necessária para que os atores sociais possam fazer as escolhas com segurança. Os novos "conceitos de pessoa" apontaram para novos padrões de consumo, ao mesmo tempo em que foram por eles regidos (McCracken, 2003).

As tantas transformações que marcaram o mundo ocidental desde a industrialização não foram caracterizadas como revoluções somente pela mudança nos hábitos de compra, gostos e preferências, mas sim pela alteração nos conceitos culturais, nas relações humanas com o tempo, o espaço, a família, o corpo, a economia, a coletividade política. A cultura ocidental tornou-se cada vez mais condicionada e unificada pelos bens e práticas de consumo que depositaram significados nos corpos e subjetividades. A rotatividade da produção foi acelerada e os profissionais da mídia não pararam de trabalhar para aumentar a intensidade das dinâmicas da moda. Técnicas de persuasão que inventavam estilos e davam descrédito para artigos antigos foram constantemente aperfeiçoadas (McCracken, 2003). Os bens passaram a não ter mais compromisso com longevidade ou com o grupo familiar em si. O dilema do novo se instaura e se torna um vício incessante (Morin, 1989 [1962]). A nobreza como valor social geracional entra em declínio face ao consumo como elemento que proporciona o novo valor de nobreza aos cidadãos.

Georg Simmel (2008 [1905]) foi um dos autores pioneiros na percepção dessa transformação cultural. No início do século XX, ressaltou o trânsito social instituído pela adesão ao consumo. A oscilação entre as diferentes camadas sociais foi denominada pelo sociólogo de efeito "trickle-down", uma espécie de deslocamento que se dá quando os indivíduos de baixa posição começam a ter acesso e adquirir os bens dos indivíduos de alta classe. Com isso, os abastados transferem-se forçadamente para outros marcadores de posição social. Com suas 
categorias de produtos sendo copiadas pelos grupos inferiores, a classe superior passa a criar inovações, conceber novas modas. Um ciclo infindável de renovação se impõe ao corpo social. A perda de determinados símbolos pela fidalguia provoca o surgimento de outras representações de status. Williams (1982) destaca como a burguesia do século XVIII imitou a aristocracia, à medida que reconhecia como a economia privada permitia o consumo conspícuo. Os grupos que antes possuíam distinção através dos signos pertencentes aos seus antepassados agora se veem subordinados ao incessante princípio da moda e o poder do capital. A mobilidade social não está mais atrelada ao legado geracional, ela pode ser conquistada de maneira imediata através do consumo. A renda é convertida em status instantaneamente através dos produtos. $\mathrm{O}$ consumo proporciona uma nova configuração social, variante, transitória, instável, com classificações inconstantes construídas a cada movimento histórico.

$\mathrm{Na}$ cultura moderno-contemporânea, a publicidade seria este sistema classificatório que batiza e dirige as escolhas das novas gerações (Rocha, 1985). Classificar é impor um padrão, uma ordem, um modelo a ser seguido, é organizar as diferenças, regular os sentidos, estabelecer uma fronteira simbólica que traduzirá e orientará as práticas sociais. É a partir dos sistemas classificatórios construídos e negociados entre os grupos sociais que as interpretações de mundo são legitimadas. O exercício da classificação permite demarcar o que é certo e o que é errado, o que é aceitável e o que é proibido em determinada cultura.

A ideia de que o discurso publicitário aciona ou edifica um sistema de classificação na cultura moderno-contemporânea é decorrente de uma reflexão que observa o social a partir de movimentos contínuos de semelhanças e diferenças, posicionamentos dinâmicos de elementos que impõem hierarquias. São divisões categóricas que oferecem guias para a compreensão e localização no mapa da cultura.

Assim, o discurso publicitário, produzido e colocado em circulação pelos meios de comunicação, dá vazão, apelo e visibilidade a valores já presentes no imaginário coletivo, como também é capaz de articular significados inéditos que serão gradativamente incorporados aos modos de vida. A vocação classificatória da publicidade é oriunda de um diálogo e uma interseção profunda entre os meios de comunicação e os atores sociais, sobretudo com a subjetivação dos valores da cultura de massas e sua penetração nas experiências. A narrativa publicitária irá 
relacionar produtos aos hábitos de determinados tipos de pessoas, atribuindo significados culturais aos bens, apontando os espaços que eles devem ocupar e a maneira pela qual devem ser usados. Os anúncios apresentam uma espécie de cartilha, sugerem ensinamentos, tanto sobre utilidades materiais, quanto sobre regras sociais estabelecidas a partir do consumo de mercadorias fabricadas em grande escala.

Para Baudrillard (2010 [1970]), nunca consumimos o objeto em si, no seu valor de uso, consumimos os objetos manipulados por signos que distinguem o indivíduo, quer alocando-o em seu grupo social ideal, quer diferenciando-o dentro deste grupo por referência a um grupo de status superior. O sistema publicitário oferece perspectivas para a compreensão dos vínculos de sentidos travados entre os objetos - mediatizados através de marcas e anúncios - e consumidores.

Consumir, portanto, se torna uma ação de comunicação, troca e repartição de sentido, um ritual em que são ativados sistemas classificatórios para traçar as estratégias pessoais de ação social. Os esquemas de classificação são elaborados a partir da relação entre bens e pessoas. Campbell (1987) argumenta que não existe um único sistema absoluto que dê conta dos significados que os objetos podem ter em uma determinada cultura e tempo histórico. Os artefatos podem assumir múltiplos sentidos em distintos contextos. Além disso, para o autor, a dimensão comunicativa só se completa com a compreensão do outro. Se o interlocutor não tiver elementos culturais para decifrar os significados decorrentes de uma emissão comunicativa, o sentido não se deduz ou vai por outros caminhos. A mensagem pode assumir diferentes conotações interpretativas, dependendo de como será percebida pelo receptor. Neste contexto, a informação transmitida pode ser decifrada de maneira completamente equívoca a que se intencionava.

A narrativa publicitária pode ser entendida como um discurso social que pretende firmar, estabilizar, manter esses significados que são tão voláteis. O objetivo é consolidar signos em certos contextos, criando uma linguagem comum de compreensão da realidade, onde o diálogo é rematado através do consumo. A relação entre pessoas e objetos é interligada pelos sistemas de classificação publicitários, que acionam sentidos fundamentados em categorias culturais, eixos plurais que não estabelecem parâmetros fechados ou cartesianos. Os anúncios irão efetivar significados em certos contextos, por espaços de tempo sempre muito efêmeros, uma vez que a rotatividade dos significados precisa ser constantemente 
revista e reelaborada, a fim de manter viva a lógica giratória do sistema de consumo. Logo, a dimensão histórica é essencial para a transformação dos critérios de distinção. Novas classificações e escalas de valores sociais são constituídas ao longo do tempo, e podem ser observadas através do discurso publicitário. $\mathrm{O}$ investimento em certas linhas narrativas pela mídia está intimamente atrelado aos interesses dos anunciantes e ao tempo histórico-cultural em que estão inseridos. Na década de 1980, por exemplo, fumar cigarros era uma prática extremamente estimulada pela publicidade, que promovia o tabagismo como símbolo de prestígio, afirmação em determinados grupos, emblema de sucesso profissional e pessoal. As memoráveis propagandas de cigarro Hollywood traduziram o espírito da época e ditaram um estilo de vida almejado por muitos no período. Na maioria dos comerciais, jovens bonitos e atléticos eram mostrados praticando esportes radicais em lindas paisagens ao som de músicas conhecidas. A indústria do tabaco estava numa trajetória ascendente, e além de influenciar os ideais e práticas de toda uma geração, também se tornou um dos principais anunciantes da mídia de massa, investindo em propagandas milionárias. Nas novelas dos anos 1980 era comum assistirmos personagens bem-sucedidos com um cigarro nas mãos. A partir da década de 1990, o hábito de fumar começou a ser condenado pela sociedade brasileira. Em 15 de julho de 1996, a Lei 9.294/96 proibiu a publicidade de produtos derivados do tabaco nos veículos de comunicação. A propaganda comercial de cigarro ficou restrita a pôsteres, painéis e cartazes na parte interna dos pontos de venda ${ }^{19}$. Às empresas de tabaco foi vetado, inclusive, o direito de patrocinar atividades culturais e esportivas. Estimase que essa fatia de mercado foi tomada pelas grandes empresas de cerveja, mesmo com a proibição dos anúncios de bebidas alcoólicas antes das 21 horas. Assim, apesar do álcool ser um dos maiores problemas de saúde pública no mundo, não temos propagandas que estimulem, ou legislação que proíba, a população a parar de beber.

Podemos observar que regulações que foram valorizadas em um determinado momento cedem lugar a argumentos totalmente opostos em outro. Com a explosão demográfica ao redor do planeta nas últimas décadas e o aumento da expectativa de vida, preocupações com a saúde e o meio ambiente tomaram

\footnotetext{
${ }^{19}$ Fonte: http://www.planalto.gov.br/ccivil_03/leis/L9294.htm
} 
conta do discurso social e foram, naturalmente, incorporadas pela narrativa publicitária em suas produções. Assim, o cigarro foi estigmatizado como um vilão dos novos princípios sociais. Em outubro de 2011, a Organização das Nações Unidas anunciou que a população mundial chegou à marca de sete bilhões de habitantes ${ }^{20}$. Enquanto em 1980 tínhamos uma previsão de 62,7 anos de vida, a média atual alcança os 73,9 anos. Em três décadas tivemos um aumento de 17,9 \% na expectativa de vida no Brasil, segundo o Relatório de Desenvolvimento Humano 2014 do Programa das Nações Unidas para o Desenvolvimento (PNUD). Saúde e bem-estar se tornaram expoentes culturais e objetivos simbólicos em espaços em que o consumo funciona como bússola social (Aucar; Rocha, 2012). Sendo assim, esses mapas de orientações sociais-culturais que invadem a vida contemporânea não poderiam deixar de ser privilegiados pelas escolhas publicitárias. Cuidados com o corpo, prática regular de exercícios, novas técnicas de controle das ansiedades, alimentação saudável, bom uso dos recursos naturais, apreço pelas questões ambientais foram alguns dos temas que ganharam força e adesão a partir dos anos 1990. Na esteira dessas transformações culturais nos deparamos com algumas mudanças do espaço urbano e dos hábitos de consumo, tais como multiplicação de academias de ginástica, recordes de cirurgias plásticas $^{21}$, aumento de feiras e alimentos orgânicos nos supermercados, além de uma propagação sem precedentes de produtos para a estética, beleza e lazer. Ou seja, o sujeito moderno-contemporâneo vive mais. Para viver mais, ele precisa trabalhar mais e manter um corpo saudável, em plena capacidade produtiva. $\mathrm{O}$ aumento da produção estimula diretamente um aumento do consumo. Incitar uma vida saudável e acirrar a força de trabalho dos sujeitos são artifícios presentes na narrativa publicitária para a sustentação de parâmetros ideológicos do tempo presente (Aucar; Rocha, 2012). O discurso da mídia dará relevo às questões que fazem parte do nosso modelo cultural, sobretudo em relação aos padrões idealizados pelo mercado que sustentam a produtividade e intensificam o consumo. Daí a ênfase publicitária à ideia de juventude que se expande, tanto para cima, quanto para baixo. Uma categoria que se tornou cada vez mais elástica,

\footnotetext{
${ }^{20}$ Fonte: Fundo das Nações Unidas para População: http://www.unfpa.org/pds/trends.htm

${ }^{21}$ Relatório da Sociedade Internacional de Cirurgia Plástica Estética divulgou que o Brasil lidera o ranking mundial de cirurgias plásticas. Em 2013, o país realizou 1,49 milhão de operações, quase 13\% do total mundial. Nos Estados Unidos foram 1,45 milhão. Em terceiro lugar está o México, com 486.000 cirurgias. Fonte: www.isaps.org
} 
comprimindo a infância e afastando a ideia de maturidade. Diferentemente das demais faixas etárias, o jovem é visto como um ser produtivo, influente, eficiente, com amplo poder de escolhas, importante mediador dos modos de consumo das famílias (Rocha; Pereira, 2009).

Logo, podemos dizer que a publicidade aciona uma dimensão comunicativa essencial ao sujeito contemporâneo, ao instituir discursos, tanto sobre mercadorias, quanto sobre pessoas em torno de temas dominantes do momento histórico em que os grupos sociais estão inseridos. A publicidade ativa mecanismos relacionais capazes de esclarecer parâmetros de valores, localizações, interpretações, posicionamentos sobre o significado dos produtos e quem os consome. As narrativas não se destinam apenas ao propósito mais evidente de vender produtos, como também são importantes mecanismos de categorização dos sujeitos. Hierarquias simbólicas são acionadas no imaginário coletivo através da aderência a produtos e serviços. Os objetos transcendem suas funcionalidades ou utilidades definidas por signos e símbolos que trazem outras correspondências subjetivas, tanto na lógica social, quanto na lógica do desejo instável e inconsciente (Baudrillard, 2010 [1970]).

O processo de diferenciação que surge como um mecanismo pelo qual os sujeitos se inserem na vida coletiva não é vivido como uma imposição social, obediência a códigos de conduta, e sim como um processo de livre escolha, franca ambição por insígnias que elevem o status individual pelo consumo. Baudrillard (2010 [1970]) assegura ainda que a diferenciação ultrapassa o âmbito do individuo único, pois é justamente no aspecto relacional da sociedade que o caráter infinito do consumo pode ser explicado.

Diferenciar-se equivale sempre a instaurar a ordem total das diferenças, que constitui sem mais o facto da sociedade total e ultrapassa inelutavelmente o indivíduo. Ao distinguir-se na ordem das diferenças, o indivíduo restabelece-a, condenando-se, portanto, a inscrever-se nela só de modo relativo. Cada indivíduo vive os próprios lucros sociais diferenciais como lucros absolutos e não o constrangimento estrutural que está na origem da permuta das posições e da permanência da ordem das diferenças. (BAUDRILLARD, 2010 [1970]: 67).

Se fossemos considerar apenas o valor de uso dos bens, a necessidade e a satisfação dos mesmos rapidamente estariam saturadas. O que vemos é justamente 
o contrário, uma aceleração dos motivos para o consumo, uma produtividade incessante e procura ininterrupta por bens que se renovam - e se mantém iguais a cada novo ciclo produtivo. A lógica classificatória é decisiva para a renovação dos gostos, das posições sociais, dos símbolos de prestígio, das representações de autoridade, garantindo assim o consumo conspícuo ativo, movediço e ininterrupto, bem como a dimensão ilimitada do processo de aquisição de bens. A diferenciação leva o consumidor a aludir-se indefinidamente a outros símbolos e o induz à insatisfação.

Baudrillard (2010 [1970]) também ressalta que a ideia de satisfação ou a frequente falta dela está referenciada em nossa sociedade pela ligação entre o consumo e a noção de felicidade ou salvação. Tal noção não é intrínseca ao sujeito que busca a autorrealização natural, instintiva, ela é um preceito ideológico historicamente construído a partir do que o autor vai chamar de "mito da igualdade" (BAUDRILLARD, 2010 [1970]: 49), que recai sobre as sociedades modernas a partir da industrialização. Este marco instala uma ideia de felicidade que deve ser ostentada em critérios visíveis, evidências materiais a que todos podem ter acesso. Se instauramos a produtividade como o centro de nosso sistema social, a abundância da produção conquistada através do progresso contínuo e regular deveria assegurar a felicidade igualitária para todos os cidadãos. O "mito da igualdade" suprime as determinações históricas e sociais que outrora diferenciaram os segmentos sociais, e baliza o consumo como o grande instrumento de acesso à igualdade e, portanto, à felicidade. A exigência igualitária se alicerça nos princípios individualistas e não nos fundamentos coletivos. A finalidade da sociedade de consumo, de forma idealizada, seria proporcionar o conforto total a todos os seus integrantes.

O bem-estar passou a ser mensurável por objetos e signos de comodidade. Todos são iguais na possibilidade de acesso ao valor de uso dos bens e suas satisfações, o consumo tem um potencial democrático, podendo servir a todos os homens. No entanto, como mostra Levi-Strauss (2012 [1962]), a diferenciação é uma prática produzida por toda sociedade, categorizações são engendradas a todo o momento como forma de estabelecer demarcações sociais. O desequilíbrio é o responsável pela manutenção hierárquica de um grupo e pelas diferentes posições e atividades que os sujeitos precisam dar conta para a sociedade funcionar. 
Ademais, não existe igualdade sem a diferenciação. É a alteridade que faz a sociedade existir e expressa seu mecanismo ideológico. A aparente democracia capitalista mascara a impossibilidade de uma igualdade social. A distribuição desigual de riquezas promove um acesso diferenciado aos produtos da sociedade de consumo, logo, um acesso irregular à ideia de felicidade. Abundância de produção não supõe igualdade de distribuição. A ordem social desequilibrada divide a sociedade moderno-contemporânea em torno de camadas de privilégios e dominações (Baudrillard, 2010 [1970]). Os princípios valorizam a igualdade, mas a estrutura se mantém a partir do exercício de superioridade de uns sobre outros. A proeminência se dá pelas vias do consumo que atribui valoração cultural aos objetos, signos de prestígio e poder.

A publicidade, como uma grande emissora de orientações identitárias do mundo moderno-contemporâneo, difunde socialmente os ideais de felicidade em suas narrativas e imagens. Nos anúncios não existe infortúnio, frustração ou dor. No mundo projetado pelos anúncios tudo pode ser resolvido, o princípio do prazer é garantido, o desejo é pleno. "Na "vida" definida dos anúncios a casa é sempre acolhedora, o trabalho, nunca alienante, o sono, perpetuamente tranquilo. Jamais o incômodo, o desconforto, a tristeza.” (Rocha, 1985: 140). São narrativas de modelos ideais. A publicidade vende a ideia de prazer, que se tornou universalizante com a cultura de massas, desenvolve no imaginário e na informação romanceada os temas da realização pessoal, do amor, da sedução, da magia (Morin 1989 [1962]).

Para compreendermos como essa magia publicitária acomete as subjetividades humanas, a ponto de fazer com que o consumo se torne um fenômeno social definidor de nossa ordem cultural, é preciso ressaltar o agigantamento do setor da racionalidade em nossa formação histórica ocidental. A partir da constituição da modernidade vamos, pouco a pouco, nos opondo aos modelos praticados na Idade Média, abolindo as práticas anteriores. $\mathrm{O}$ pensamento racional vai expulsando o pensamento mágico, místico, sobrenatural, sagrado. Assim, é preciso ponderar como a magia sobrevive em meio a um mundo que estabelece a razão como mola de funcionamento.

A coletividade e a adoração ao plano do sagrado eram marcas da Idade Média. O período histórico é marcado por amálgamas, junções, desordens coletivas, ambientes carnavalescos, de risos e orgias. Não existiam delimitações 
tão explícitas, inclusive na arquitetura - não era comum termos portas e fechaduras dividindo espaços - e praticamente todos os atos aconteciam em público (Bakhtin, 1999 [1965]). Com a formação da modernidade, separações, rupturas, fragmentações estabeleceram corpos fechados em individualidades muito rígidas. As esferas vão se tornando autônomas. E ciências são criadas para estudar cada uma delas.

A presença do Estado vai se disseminando até se naturalizar. Os dramas e conflitos outrora expostos publicamente são internalizados, bem como toda engenharia dos castigos é banida da visibilidade coletiva (Foucault, 2007 [1975]). O corpo individualizado segue as lógicas de aprisionamento dadas pela autoridade. A dominação é interiorizada, o sujeito se prende à sua própria subjetividade, que já está subjugada ao poder vigente de sua época. O poder passa a ser exercido por representações, signos que elaboram uma direção cultural. $\mathrm{O}$ poder simbólico, como explicita Bourdieu (1998 [1989]), é exercido sem o uso da força ou gasto de energia. Nas sociedades superavitárias, organizadas em torno dos sistemas industriais, as necessidades biológicas estão supridas e os sujeitos se dedicam integralmente à reprodução do plano simbólico (Rodrigues, 2006).

Porém, séculos antes, a razão começa a ser a justificativa para as práticas sociais. Mesmo as matizes espirituais passam a ser governadas pela obliquidade da razão. Nasce a Teologia, uma ciência para interpretar os desígnios de Deus, estabelecer uma lógica na relação dos homens com o sagrado. Por volta do século VI a.C., a filosofia grega - de cuja tradição somos herdeiros - irá então consagrar a compreensão do mundo a partir de fundamentos baseados na racionalidade, na lógica e não em princípios mitológicos, como explica Danilo Marcondes (2002):

\begin{abstract}
O pensamento filosófico-científico representa assim uma ruptura bastante radical com o pensamento mítico (...) A religião vai tendo seu papel reduzido, paralelamente ao surgimento de uma nova ordem econômica baseada agora em atividades comerciais e mercantis. O pensamento mítico, com seu apelo sobrenatural e aos mistérios, vai assim deixando de satisfazer às necessidades da nova organização social, mais preocupada com a realidade concreta, com a atividade política mais intensa e com as trocas comerciais. É nesse contexto que o pensamento filosófico-científico encontrará as condições favoráveis ao seu nascimento. (MARCONDES, 2002: 21, 22)
\end{abstract}

O mundo buscará a chave para a explicação da experiência em si mesmo e 
não fora dele, em realidades sobrenaturais. A ciência viria a ser o grande portal do conhecimento. No entanto, a história também nos mostra que, dentro desta extrema razão, a magia está presente em doses muito altas. O pensamento mágico reside e resiste em todas as formas de manifestação artísticas, na visitação aos museus, na estética das projeções arquitetônicas modernas, na vertigem das ficções cinematográficas, no encantamento com as celebridades televisivas, na adoção de feriados santos em nosso calendário, nas oferendas materiais deixadas para os deuses nos altares das igrejas, nos jogos de azar, nas práticas sexuais, na beleza dos corpos que desfilam nas passarelas, na adoração dos elementos do consumo, no ato da compra, nos anúncios publicitários.

Wagner (2010 [1975]) considera que a publicidade pode ser vista como um dos espaços onde o pensamento mágico prevalece em nossa sociedade. Os anúncios nos levam a um universo de imaginação e fantasia, eles têm o poder de transfigurar fatos da realidade cotidiana através do objeto mágico que é o produto.

\begin{abstract}
O anúncio, como moldura de acontecimentos mágicos, faz do produto um objeto que convive e intervém no universo humano. $\mathrm{O}$ anúncio projeta um estilo de ser, uma realidade, uma imagem das necessidades humanas que encaixa o produto na vida cotidiana. A verdadeira magia da publicidade é incluir o produto nas relações sociais dos receptores. O produto é introduzido e interpretado para o público pelos anúncios. Esta identificação entre as qualidades anunciadas e o produto faz com que ele entre no fluxo de nossas vidas da mesma maneira pela qual entra no fluxo das vidas dentro do anúncio. Ao consumidor resta acreditar nesta magia, e o produto passa a entrar em sua própria vida. (WAGNER, 2010 [1975]:63)
\end{abstract}

Exatamente por estar tentando dirimir ou inconscientemente indicar uma falta, o universo dos anúncios é sempre o da completude, da saciedade, da felicidade. A narrativa publicitária não fala da escassez, ela promove o encontro, apresenta a vida ideal. $\mathrm{O}$ ato da compra é a junção daquilo que você acha que precisa com aquilo que você acredita que deseja, é a união da necessidade cultural com a vontade. Através da compra, a identidade do produto é transferida para a identidade do sujeito. A compra permite uma realização, uma abundância efêmera, por isso é uma prática revestida de emoções, afetos, sensibilidades. $\mathrm{O}$ consumo, neste sentido, poderia ser visto como um fenômeno próximo das lógicas 
que regem a religião, uma vez que promove uma ligação dos homens com um "sagrado" fabricado pela cultura de massas. Se pensarmos em religião como ligação, união, o momento da compra seria uma forma de promover um entrelaçamento entre o sujeito e seu objeto de adoração, o produto. Muitas vezes a relação dos consumidores com os bens é próxima à dos fiéis em uma igreja (Rocha et al, 2013b).

A publicidade será a arena responsável por investir de "sacralidade" os produtos. Uma retórica própria é orquestrada para vender mercadorias. Entretanto, o discurso publicitário ultrapassa essa vertente. As mensagens propagandísticas oferecerão material para os sujeitos se entenderem e determinarem suas relações com o mundo, são narrativas que irão elaborar representações. O pensamento mágico é o aporte central para compor estas narrativas.

A magia publicitária que potencializa efeitos sobre as práticas dos sujeitos está relacionada com as estratagemas da esfera da sedução, descritas por Jean Baudrillard (1992). A sedução é estratégia apropriada pela publicidade para estabelecer uma relação de poder, uma forma de agir sobre o outro por meio de signos. Para se concretizar como ação sobre sujeitos, a narrativa publicitária precisa se imbricar com a sedução. Poder não é uma propriedade, é uma estratégia. Muitos dos significados e estilos de vida na contemporaneidade são derivados da articulação publicitária que vincula, através de sua influência sociocultural dada por estratagemas de sedução, os desígnios mercadológicos. A sedução publicitária premiará o sujeito para, logo em seguida, decepcioná-lo, a fim de que a falta continue a gerar novos motivos para o consumo. Um poder que, segundo Baudrillard (1992), apenas oferece a ilusão de realidade, um jogo de cena. As mensagens midiáticas se inserem no jogo da sedução, uma vez que nos desviam dos signos do mundo real, nos distraem, nos conduzem a uma vertigem imaginária, nos transportam para uma "hiper-realidade" (Baudrillard, 1991). A sedução programada pelos meios de massa incorpora a dimensão de brincadeira, de disfarce, de aparência, de encantamento, de loucura, de fortuito, de charme, de enigma, de insinuação, de aposta. Os hábitos de consumo ditados pelo escopo publicitário fazem florescer signos que, perpetuados incansavelmente, remetem a si mesmos. Signos que cativam sujeitos em círculos intermináveis de representação, simulacros de vida. Como assinala Marcel Mauss (2003): 
$\mathrm{Na}$ realidade, não se trata de traduzir em símbolos um dado extrínseco, mas de reduzir à sua natureza de sistema simbólico coisas que só escapam a ele para se incomunicabilizar. Como a linguagem, o social é uma realidade autônoma (a mesma, aliás); os símbolos são mais reais que aquilo que simbolizam. (MAUSS, 2003 [1925]:29)

Para Foucault (2007 [1975]), tais tramas crescentes que entrelaçam o sujeito em dependências simbólicas são vertentes objetivas de maior controle, densidade e aprisionamento social. Baudrillard (1992) afirmará que esse poder simbólico só pode ser exercido pela sedução, logo a sedução é maior do que o poder, é um jogo que controla esse tipo de poder. Para o autor, sem a sedução o poder não conseguiria se efetivar. A arma da sedução é a arma do símbolo, do signo. Ela não conhece os limites do real e tem o poder de ludibriar, transfigurar, iludir, transportar para a esfera da fantasia. A sedução tem o poder de produzir sonhos. Ela desvia a realidade racional e nos leva ao reino da magia.

Assim, o discurso publicitário legitima a cultura de consumo como um código responsável por boa parte das definições de felicidade e bem-estar, bem como insere o viés midiático na transmissão de referências que edificam subjetividades e promovem o relacionamento dos homens entre si e com as mercadorias (Freire Filho, 2003). Ao realizar uma compra, o consumidor é atraído pelo universo dentro do anúncio, pelo mundo mágico elaborado pela publicidade (Rocha, 1995).

Procuramos até aqui analisar a publicidade conceitualmente, especificando o que pode ser assumido como narrativa publicitária neste estudo. A publicidade está sendo pensada como uma discussão do nosso tempo modernocontemporâneo, ancorada em certas condições históricas e sociais que foram substanciais para o nascimento de uma cultura profissional e uma produção simbólica acentuada. As transformações industriais, o fortalecimento de uma coletividade urbana, o incremento dos meios de massa, a formação de um mercado consumidor com ênfase nas diretrizes capitalistas na composição dos estilos de vida foram fatores fundamentais para entendermos a publicidade como resultado de ações conjuntas e organizadas em torno de estruturas específicas. Os discursos midiáticos, entre os quais as mensagens da propaganda, passaram a legitimar certos valores morais e éticos que se concretizaram por diferentes 
âmbitos do tecido social (Freire Filho, 2007). As representações publicitárias articulam sentidos simbólicos que se põem como autoridades culturais e oferecem matéria-prima para os sujeitos ordenarem percepções de si próprios.

Para evidenciar a relevância do anúncio na esfera social e sua capacidade de estabelecer fortes conexões entre sujeitos e cultura material refletiremos sobre seus complexos sistemas produtivos. O objetivo do próximo capítulo é revelar as balizas de produção das mensagens publicitárias dentro das agências e as instâncias e cargos criados para sua execução. A perspectiva crítica de Howard Becker (1977, 1977a, 1986) destaca a cadeia de ações coletivas travadas entre os sujeitos para a formação do campo publicitário. Redes de colaboração e atividades interativas foram essenciais para que o anúncio apareça e seja percebido socialmente como uma narrativa substancial. As agências foram as instituições responsáveis por materializar essa ação em conjunto, elaborar disposições normativas e técnicas produtivas que organizaram e atribuíram reconhecimento, no limite, à própria existência, do campo da publicidade. 


\section{3 - A publicidade como ação coletiva}

Para expressar seu entendimento sobre o mundo artístico, Howard Becker (1977) recorreu a uma tradição sociológica que sustenta que o conhecimento e os produtos culturais possuem um caráter social ou uma base social (Simmel, 2002 [1898]; Park, 1950, 1952, 1955; Blumer, 1966). A arte é analisada como um fenômeno revelador de uma determinada sociedade e momento histórico.

O maior expoente vivo da Escola de Chicago é um autor bastante estudado na Antropologia brasileira, especialmente citado nos trabalhos voltados para estudos urbanos e temáticas que dialogam com o interacionismo, análise do indivíduo e da sociedade de forma ampla. A ideia de ação coletiva - doing things together - é central para a compreensão da obra de Becker, seja nos textos sobre desvios, seja nos textos sobre arte. Sua perspectiva destaca rituais e estratégias de interação como preciosos elementos para a compreensão de processos envolvidos na construção social da realidade. Os trabalhos empíricos sobre música reforçaram o diálogo com as pesquisas no Brasil, contribuindo com inovações metodológicas para as investigações da sociologia da arte e outras questões. Becker se considera um "sociólogo da música" (Becker, 2013).

O interesse pelo universo artístico é decorrente de suas preferências pessoais. Becker hesitou em encarar a carreira de cientista social, uma vez que almejava seguir a profissão de pianista de jazz. Desta forma, nunca se encaixou em rígidos modelos acadêmicos, dedicando-se a uma configuração teórica que pudesse expressar a riqueza de sua experiência e curiosidade intelectual. Mesmo com o padrão não convencional de gostos e opções, sua obra serviu de inspiração para muitas frentes reflexivas da sociedade moderno-contemporânea, sobretudo a partir dos anos 1970, depois de relativo desconhecimento e indiferença (Velho, 1990).

Gilberto Velho foi o grande responsável por divulgar a tradição interacionista no Brasil, dando ênfase às obras de Becker e Ervin Goffman, sobretudo quando começa a lecionar no Programa de Pós-Graduação em Antropologia Social do Museu Nacional, em 1972. As correntes marxistas e 
estruturalistas eram as principais referências das ciências sociais no país durante a tumultuada década de 1960. Devido a política anti-imperialista da ditadura militar, havia uma certa rejeição a propagação de autores norte-americanos. Com isso, essa produção acadêmica foi considerada de caráter extremamente prático e pouco erudito. Com a explosão da contracultura, da realização de projetos culturais e ideológicos alternativos, da grande revolução comportamental do feminismo, do aparecimento dos Hippies e seus protestos contrários à Guerra Fria, dos movimentos civis a favor de negros e homossexuais, cresce o interesse por análises críticas do cotidiano. Com esta mudança, também ganha projeção a obra de Michel Foucault (2005, [1961]). Neste momento, textos de Erving Goffman (1983 [1959], 1975 [1963]) começam a ser publicados no Brasil, mesmo com relativo atraso, chamando atenção, tanto de antropólogos, quanto de psicólogos. Cresce a preocupação com a interdisciplinaridade nos estudos sobre o cotidiano e as relações interpessoais (Velho, 1990).

Em 1974, Velho lança a coletânea de artigos Desvio e Divergência: uma crítica da patologia social (Velho, 1974), em que Becker e Goffman foram referências centrais. Através de um amigo, Becker recebeu o livro nos Estados Unidos e entusiasmou-se com os trabalhos desenvolvidos no Brasil. Este foi o início de uma próspera parceria acadêmica e afetuosa travada entre Velho e Becker, que passou a estudar a língua portuguesa para entender outros estudos sobre o tema do desvio. Em 1976, Velho conheceu o Departamento de Sociologia da Northwestern University, em Evanston, Illinois, onde Becker trabalhava. A visita serviu para estreitar laços e aprofundar o conhecimento de Velho sobre a Escola de Chicago. O intercâmbio foi consolidado no segundo semestre desse mesmo ano, quando Becker veio ao Brasil como professor visitante no Museu Nacional. Os professores ministraram um curso juntos e Becker realizou palestras no Museu Nacional, no Instituto Universitário de Pesquisas do Rio de Janeiro e nas Universidades de Brasília, São Paulo e Campinas. Inúmeros alunos (entre eles, o orientador deste trabalho) e professores tiveram a oportunidade de conversar e trocar informações com o autor americano, que se mostrou muito acessível e disposto a entender as questões que rondavam as ciências sociais brasileiras. A partir daí, divulgou trabalhos de autores nacionais, recebeu e orientou alunos brasileiros em doutorados, mantendo contato com o país através de cartas, telefone e e-mails. Veio ao Brasil outras duas vezes, em 1978 e 1990. 
Nesta última, já com um português razoável, organizou novamente um curso com Gilberto Velho: "Sociologia da Arte", quando proferiu uma célebre conferência sobre a Escola de Chicago (Becker, 1996).

Em seus trabalhos de campo, Becker pesquisou estudantes de medicina, usuários de drogas, músicos de jazz, entre outros. A problemática do desvio se constituiu em um de seus principais focos de análise, destacado, principalmente, no clássico livro Outsiders (2008 [1963]). Já desde os anos 1920, os chamados "sociólogos do desvio" estavam preocupados em entender por que certos comportamentos são considerados desviantes, fora dos padrões, e como essas classificações são aplicadas em uma sociedade. O desvio é ponderado como um fenômeno edificado culturalmente através das interações entre indivíduos, o que suscita questões em relação à formulação destes conceitos por cada grupo social. Alguns comportamentos e grupos são definidos como desviantes e outros não recebem esse rótulo. A Labelling Theory foi proposta por Becker, a fim de desenvolver análises sobre os processos de imposição de "rótulos" a certos indivíduos e as consequências dos estigmas nas subjetividades e no convívio social. Becker e Goffman foram importantes autores que reforçaram a tradição de estudos sobre desvio, divergência e acusações, reflexões que desde o final do século XIX ampliam o debate e a literatura sobre estes temas.

O desvio é considerado uma construção social e não deve ser analisado isoladamente como consequência do caos, da patologia ou da falência de uma sociedade. Para Becker (2008 [1963]), o desvio ou transgressão pode ser notado em todas as coletividades que traçam normas, regras e valores morais para a conduta social dos indivíduos. A classificação do desvio ocorre quando estes padrões são quebrados ou não respeitados. Embora associado ao comportamento imoral, nem sempre o desvio está relacionado ao não cumprimento da lei ou ao crime. O conceito é pensado de forma relativista, uma vez que os mesmos indivíduos fazem parte de muitos grupos sociais ao mesmo tempo e as referências ou diferenças de uns podem infringir as de outros. O desvio é considerado a falha na obediência às regras do grupo. Desta forma, Becker (2008 [1963]) procura explicações para a problemática do desvio dentro da sociedade e não propriamente em fatores biológicos ou psicológicos do indivíduo. O desvio, portanto, não é visto como um elemento natural e sim como um componente estabelecido por condições históricas, que variam no tempo e espaço. Os 
interacionistas se preocupam com a rotulação atribuída a certos comportamentos e os efeitos sociais de tais atributos, que em geral assumem uma conotação negativa, marginalizando o indivíduo do restante do grupo. O comportamento desviante é um status, uma categoria moldada a partir da definição coletiva para o pode e o que não pode ser considerado um desvio. A sociedade faz a seleção dos transgressores a partir de fatores como classe social, idades, gêneros, etnias, relações de poder. O termo outsider adotado por Becker (2008 [1963]:17) descreve "(...) aquele que se desvia das regras de grupo (...)", indivíduo em desacordo com as normas instituídas socialmente.

O desvio não é uma qualidade do ato que a pessoa comete, mas uma consequência da aplicação por outros de regras e sanções a um "infrator". O desviante é alguém a quem esse rótulo foi aplicado com sucesso; o comportamento desviante é aquele que as pessoas rotulam como tal. (BECKER, 2008 [1963]: 22)

O interacionismo simbólico vai distinguir os comportamentos a partir do intercâmbio entre os sujeitos, dos esquemas estabelecidos por grupos, dos estereótipos criados para os diversos papeis sociais. Assim, o comportamento dos indivíduos é resultado dos mecanismos de interação, dos elos estabelecidos socialmente. A teoria da ação coletiva expressará as redes que colocam os componentes sociais em convívio e dependência. As identidades sociais são concebidas como a internalização dos processos socialmente construídos em cada espaço e momento histórico, os comportamentos são arquitetados no discurso da ação (Becker, 1977a).

Podemos descrever os membros dos diversos mundos adotando como critério o grau em que participam ou dependem dos comportamentos regulares que constituem a ação coletiva do mundo a que pertencem e dos quais dependem do resultado desta ação. (BECKER, 1977a: 11)

As práticas derivadas do campo da comunicação (publicidade, jornalismo, cinema etc.) são, entre outras coisas possíveis, processos de interação simbólica. Neste sentido, a abordagem interacionista de Howard Becker (1977, 1977a) pode ser aplicada para uma interpretação do mundo da publicidade. Assim como a arte, 
as condições de existência da narrativa publicitária são resultado e expressão de tipos de interação social e ação coletiva que se materializam dentro do ambiente das agências de propaganda. Ou seja, é possível compreender o discurso que a publicidade deposita na cultura considerando o resultado da ação conjugada de identidades, cuja colaboração é necessária para que o trabalho seja realizado de determinada forma. Seguindo a teoria de Becker (1977), podemos dizer que um "mundo" se define a partir da totalidade de identidades e organizações que produzem determinadas ações necessárias para a existência de acontecimentos e produtos específicos e próprios de tal "mundo". Seja qual for o objeto da produção, qualquer universo pode ser demarcado pelo conjunto de atores sociais que realizam atividades correlacionadas para esta produção aparecer: "Toda atividade é o trabalho de alguém. Isso quer dizer que para compreender uma atividade, qualquer que seja, é necessário pesquisar junto às pessoas para quem aquela atividade é um trabalho." (BECKER, 2013:132). Atores e suas ações são parte determinante do conhecimento e da construção de identidades culturais dos sistemas de organização social. São as atividades coletivas humanas que criam os produtos sociais e as marcações identitárias, bem como as estruturas que proporcionam os sistemas de criação destes produtos e identidades.

Nesse sentido, as considerações teóricas de Pierre Bourdieu (1983[1976]) sobre a produção simbólica, com destaque para os conceitos de campo e habitus, dialogam com as críticas de Becker. Para Bourdieu (1983 [1976]) o espaço social tem múltiplas facetas e funciona como uma grande dimensão organizada em campos específicos, entre eles o jornalístico, publicitário, econômico, político, artístico, esportivo, que se situam no campo maior que é o campo social. O campo é fixado por um sistema de posições ocupado por indivíduos, grupos ou instituições, independentemente de quem ocupe tais lugares. São as ocupações que transmitem suas características para a construção de cada identidade cultural e para as relações de poder exercitadas no campo. A delimitação do campo é construída através das lutas e conflitos travados entre os atores sociais, que irão estabelecer redes de relações, deliberações, restrições e oposições dentro de cada campo. Um campo específico é um meio social como outro qualquer, mas que obedece a leis particulares, hierarquias próprias, capitais simbólicos intrínsecos, possui disputas de poder, interesses, alianças, competições, agentes de prestígio e mecanismos de submissão. As ações individuais ou coletivas se dão dentro da 
normatização criada e transformada pelos próprios agentes, que atualizam constantemente a dinâmica do campo e suas relações com o espaço social como um todo (Bourdieu, 1983 [1976]). O conceito de campo estaria mais ligado às redes de poder travadas em um espaço simbólico e a análise de Becker mais concentrada nas cadeias de ações, nas estruturas de apoio de um mundo social e suas atividades conjugadas.

Seguindo essas reflexões, o mundo da publicidade pode ser pensado a partir do grupo de pessoas e instituições que produzem os acontecimentos e objetos definidos por eles próprios como uma narrativa publicitária. Podemos entender a publicidade através da articulação das identidades individuais projetadas dentro de uma agência de propaganda, seus elos cooperativos, suas redes de convenções para a materialização desse tipo de mensagem midiática. Além dessa conjuntura intrínseca da publicidade, também é possível considerar, de forma mais ampla, a publicidade como uma atividade definidora de nosso mundo social, uma vez que ela produz um tipo de acontecimento - o anúncio que só é possível no contexto capitalista moderno-contemporâneo, e através dele consegue transformar a realidade cultural e subjetiva dos sujeitos.

Grande parte da bibliografia sociológica se concentra nos sistemas sociais, apontando correspondências que dão pouco relevo à análise das ações dos atores sociais que formam as organizações (Velho, 1990). Becker destaca justamente a participação destes atores e o encadeamento de todas as atividades para que um sistema apareça. "As ações coletivas e os acontecimentos que elas produzem são as unidades básicas de investigação sociológica.” (BECKER, 1977: 222). A organização social se fundamenta no modo como as pessoas atuam em conjunto para produzir uma abundância de eventos diferentes de maneira cíclica. Ao pensar o mundo artístico, o autor elencará todas as atividades que devem ser realizadas para que uma obra de arte qualquer exista no plano social:

Para que uma orquestra sinfônica dê um concerto, por exemplo, instrumentos precisaram ser inventados, fabricados e conservados, uma notação precisou ser planejada e a música composta utilizando-se aquela notação, as pessoas devem ter aprendido a tocar aquelas notas nos instrumentos, horas e locais para apresentações precisaram ser providenciados, anúncios para o concerto foram colocados, publicidade preparada e entradas vendidas e uma plateia capaz de ouvir e de alguma maneira entender e responder à apresentação precisou ser recrutada. (BECKER, 1977: 206) 
Um repertório de atividades semelhantes e cadeias de correspondências também podem ser aplicados para explicar o aparecimento de um anúncio na esfera social. Para que tenhamos uma narrativa publicitária tentando vender um produto qualquer na televisão, por exemplo, temos que ter profissionais capazes de inventar as ideias, textos e imagens que este anúncio irá veicular. Para isso, esses profissionais tiveram que ser contratados, treinados e moldados por agências de publicidade, organizações que se especializaram no oficio de elaborar anúncios. Agências tiveram que ser criadas por operadores que desejavam profissionalizar o campo da publicidade. Neste ambiente corporativo, identidades próprias foram moldadas pouco a pouco de acordo com as convenções criadas para o meio. Além das identidades, departamentos tiveram que ser organizados e funções estabelecidas para que uma espécie de "cartilha" da produção de anúncios pudesse ser definida para estes agentes produtores.

Por exemplo, a produção de um filme publicitário, eventualmente formulado na agência, demanda a reunião e articulação de cinegrafistas, editores e diretores. Em geral, estes profissionais são terceirizados, prestam serviços pontuais para as agências. Para a realização da demanda, tais profissionais, por sua vez, também tiveram que aprender os preceitos da construção audiovisual, o manuseio de câmeras e o aparelhamento das máquinas de edição. Todos esses equipamentos tiveram que ser concebidos, fabricados e postos em circulação na sociedade.

Negociações entre a agência e a emissora tiveram que ser travadas por sujeitos investidos de suas identidades profissionais, a fim de conseguir espaços na programação televisiva para que o anúncio pudesse circular. Previamente, a ideia de grade de programação precisou ser inventada, intercalando a programação televisiva em blocos divididos por comerciais. Preços foram estabelecidos em relação ao tempo de exibição do anúncio, os programas foram mensurados por suas respectivas audiências e, assim, acordos foram firmados com o setor comercial da emissora. Departamentos de Mídia tiveram que ser instituídos dentro das agências para mediar esse tipo de acordo com os múltiplos canais de comunicação. Também foi preciso que telespectadores daquela faixa de horário dispusessem de condições de apreensão da mensagem publicitária e seus códigos narrativos. Logo, o campo publicitário também precisou criar uma linguagem própria que permitisse a compreensão de seus anúncios pelos 
consumidores. Antes de tudo, entretanto, foi necessário ter o produto em si, em geral um artigo manufaturado por sistemas industriais que recebe a marca de uma instituição ou empresa organizada em preceitos capitalistas. Para a criação do anúncio, a corporação contratou a agência, a fim de impulsionar as vendas de seu produto. E, sobretudo, um público consumidor capacitado para, de alguma maneira, entender e responder a esses estímulos também precisou ser recrutado.

Em termos gerais, estamos falando sobre atividades necessárias que interligadas formam uma rede de colaboração, baseada em divisões de trabalhos, para que o acontecimento do anúncio se realize socialmente. Caracteristicamente, as ações incluem a concepção da ideia para o anúncio, o desenvolvimento de artefatos físicos para a sua realização, a formação de instituições que encadeadas dão forma às leis e regras das transações e do mercado, o treinamento de profissionais que entendam e aperfeiçoem o funcionamento estrutural interno das agências de publicidade, a elaboração de uma linguagem própria adequada aos fins de compreensão de determinados interlocutores sociais, o adestramento de um público consumidor que capte as mensagens e as traduza em forma de consumo e estilos de vida. Esta mistura de ingredientes somente foi possível com a constituição de um sistema cultural que baseie as atividades sociais em relações de compra e venda, produção ininterrupta de bens e organizações que perpetuem a lógica econômica como o postulado central da vida comunitária.

Como vimos no capítulo 2, as agências só se desenvolveram com a necessidade das sociedades industriais em estabelecer uma comunicação que ultrapassasse os redutos locais de comercialização de bens e serviços. A partir das primeiras décadas do século $\mathrm{XX}$, as mensagens publicitárias passaram a ser fundamentais no esforço de vendas e no processo de aceleração, expansão e multiplicação de mercados mundo afora. Anúncios produzidos por agências e distribuídos em meios de comunicação foram responsáveis por formar novos mercados consumidores e identidades culturais ajustados aos conteúdos publicitários e atento às novidades trazidas pelo imaginário que esses mesmos meios promoveram. Tal público se constituiu com a intensificação, pelo volume e diversidade, da produção industrial, a expansão das fronteiras comerciais para além da Europa e a universalização dos valores da cultura de massas (Morin, 1989 [1962]). Antes dessas transformações culturais que convencionamos chamar Revolução Industrial, os consumidores conheciam os fabricantes dos produtos e 
suas propriedades eram divulgadas pelos próprios artesãos das pequenas comunidades, sem a necessidade de organizações que elaborassem estratégias de comunicação mais refinadas. Sendo assim, o alargamento da comunicação massiva foi determinante para o aparecimento das narrativas publicitárias. Foram as plataformas de comunicação que passaram a levar as mensagens do campo da publicidade para além dos limites até então conhecidos. Sem os meios, as mensagens ordenadas pelas agências não teriam espaços para difundir e consequentemente envolver o consumidor e transformar suas referências de identidade. Também, inversamente, sem as agências dificilmente os meios se sustentariam historicamente e, sobretudo, na intensidade e do modo que experimentamos no tempo presente. Portanto, o acontecimento do anúncio está atrelado e dá forma à expansão midiática, ampliação cultural que se articulou perfeitamente como dispositivo de conservação das finalidades do sistema econômico capitalista, ajudando a proliferar simbolicamente o modo de produção industrial e a formação de uma estrutura social de base urbana e consumista. Os meios de comunicação elaboraram um mundo que coexiste com o das agências de publicidade, mantendo uma relação simbiótica, estável e de retroalimentação. Os campos dialogam e formam conexões externas entre si, nesse sentido, desfrutam de autonomia parcial, uma vez que não podem excluir totalmente certos tipos de dependência (Bourdieu 1983 [1976]).

Becker (1977) coloca que todas as atividades que conhecemos envolvem circuitos elaborados de colaboração e uma divisão do trabalho. Dentro do processo de aparecimento, seja de uma representação, seja de um artefato, existem muitos envolvidos nas diferentes etapas do trabalho. É preciso uma cadeia de tarefas e um concatenamento de atos propositivos para que a realização de algo seja efetivada. É claro que as várias ações podem eventualmente coincidir em uma mesma pessoa. Uma divisão de atividades é resultado de uma definição consensual prévia da situação ou do campo (Bourdieu, 1983 [1976]).

No caso da narrativa publicitária, os elos de cooperação pensados por Becker (1977) para definir a constituição de determinado campo e sua representação identitária estariam aglutinados em torno da estrutura das agências de propaganda. A agência reunirá todas as premissas necessárias para a fabricação de mensagens públicas a respeito de produtos e serviços. O aparecimento das agências organizou e demarcou o mundo profissional da 
publicidade. Bourdieu (1983 [1976]) considera que são as instituições que têm o poder de fala no social, se colocando até acima da voz dos sujeitos particulares. Sendo assim, a legitimidade do campo é a autorização outorgada pelos próprios agentes sociais em conjunto, é a credibilidade dada ao setor para a construção e circulação de determinadas identidades na vida coletiva.

As diferentes etapas que hoje envolvem atividades como criação, planejamento, produção e veiculação de campanhas foram originadas, cunhadas e instituídas no âmbito das agências, o que trouxe uma aparência de profissionalismo e reconhecimento para o trabalho do publicitário. Dentro do campo profissional, as definições consensuais foram elaboradas pelos grupos de poder, são discursos dos dominantes que se põem como práticas, instrumentos de ação de uns sobre outros com a composição de diretrizes que o grupo deve seguir e acreditar. Cada agente ou grupos de agentes assumirão uma força específica dentro deste universo e ocuparão uma "posição relativa" nesse espaço. O conjunto de forças objetivas do campo é imposta a todos os agentes, inflexíveis aos desígnios individuais (BOURDIEU, 1983 [1976]:220). Uma vez instituídas, são como que apagadas as relações de poder que as originaram no campo e a percepção dominante que governa as práticas passa ser a de uma "naturalidade" ou a de uma "lógica autoevidente".

Com a gerência de todos os processos relacionados à confecção de um anúncio integrada por agências de propaganda, um campo se constituiu e a publicidade ganhou uma nova representação e importância na esfera social. A agência instaurou uma rotina própria para a fabricação de anúncios, maneiras convencionais de desempenhar atividades em que seus membros se dedicaram habitualmente por meio de suas funções de competência, ou seja, os profissionais foram treinados para realizar com facilidade e eficiência tudo que precisa ser feito. Antes das agências, os pressupostos capazes de reger a atividade publicitária estavam dispersos e desorganizados, o que embaraçava e mesmo impedia o reconhecimento do campo. As agências, assim como em qualquer campo do conhecimento, desenvolveram formas padronizadas de apoio, significados convencionais que sustentaram sua estética própria e aceitaram as restrições possíveis das ações em cooperação. 


\section{1 - Representações culturais do publicitário}

A agência se torna a instância responsável por assessorar qualquer empresa capitalista em suas necessidades de divulgar a si mesma ou vender o que deseja. Entre as atividades articuladas que seus profissionais exercem estão a criação e execução de ideias para venda de um produto ou serviço, contato e interposição de relações entre o cliente e o veículo de comunicação, coordenação dos trabalhos de fornecedores e produtoras, avaliação de custos e despesas para que o anúncio aconteça, seja para a agência, seja para o empresa que a contratou, seja para a mídia que o veiculou ou para público ao qual pretende atingir.

Desde seu aparecimento - no Brasil, em 1914, com a Eclética - a agência foi projetada privilegiando o interacionismo na elaboração de anúncios. O esforço integrado entre as várias partes da organização dá forma ao planejamento e implementação de um produto de comunicação. Dentro de uma agência nada existe isoladamente, os departamentos são conectados e integrados, e uma função depende da outra. Uma agência de publicidade se distingue de qualquer outra empresa do mundo corporativo principalmente por seus departamentos de Atendimento, Planejamento, Mídia e Criação. São divisões específicas, cujas funções só podem ser desempenhadas por publicitários. Portanto, há uma diferenciação muito clara dentro das agências entre os publicitários e os nãopublicitários. A oposição entre as equipes de publicitários e os profissionais de administração que também atuam nestas empresas é nitidamente marcada, uma vez que busca privilegiar a primeira categoria (Knoploch, 1980).

Lévi-Strauss (2012 [1962]) mostra que a posição relativa de cada categoria é sempre definida em relação às outras funções existentes em um meio. Sem uma categoria a outra não pode ser demarcada. Assim, particularizar uma categoria é uma forma de delimitá-la e defini-la por exclusão. Em uma oposição, quando atribui-se valor a uma determinada categoria, há uma positividade e uma negatividade instituídas pela ideologia de quem criou a valoração. Bourdieu (1983 [1976]) sublinha que para cada posição ocupada por um agente dentro de um campo é necessário a existência de posições vizinhas. A quantidade de capital simbólico, cultural, social e econômico acumulada por um agente vai determinar sua atuação e representar um poder sobre o campo num dado momento. A posição 
de um agente é definida pela posição que ele ocupa na distribuição dos poderes daquele campo e na conexão com o espaço social.

Pode-se descrever o campo social como um espaço multidimensional de posições tal que qualquer posição atual pode ser definida em função de um sistema multidimensional de coordenadas cujos valores correspondem aos valores das diferentes variáveis pertinentes: os agentes distribuem-se assim nele, na primeira dimensão, segundo o volume global do capital que possuem e, na segunda dimensão, segundo a composição de seu capital - quer dizer, segundo o peso relativo das diferentes espécies no conjunto de suas posses. (BOURDIEU, 1983 [1976]: 135).

Dentro das agências há um sistema de importância e prestígio estabelecido culturalmente para cada uma das funções profissionais desempenhadas nos diferentes setores. É o capital simbólico que atribuirá esta distinção entre os atores sociais. A diferenciação será percebida pelos agentes do grupo dotados de categorias de percepção desenvolvidas através da incorporação dos valores da instituição e de sua estrutura funcional. Assim, à medida que vamos nos familiarizando com a linguagem interna deste ambiente profissional, estas oposições valorativas se tornam evidentes, naturais. A hierarquização das posições é a efetivação do capital simbólico e o reconhecimento dado pelos outros agentes do campo que participam desta estruturação. A força é exercida com a cumplicidade tácita dos que praticam e dos que sofrem as influências deste poder (Bourdieu, 1983 [1976]).

A construção de uma identidade cultural própria para a profissão de publicitário, através das convenções instituídas ao longo do tempo, fez com que a atividade, marginalizada como um ofício menor ou até mesmo não percebida como tal nas primeiras décadas do século XX, ganhasse, pouco a pouco, uma posição social estabelecida e com ela status e prestígio. O depoimento do publicitário Francisco Gracioso ilustra a dificuldade de percepção que a atividade carregava naquele tempo:

Em 1937, quando a propaganda começou a lançar raízes mais profundas em nosso mundo comercial, as atividades publicitárias não deviam ocupar mais de 200 pessoas em todo o Brasil. A propaganda era considerada uma atividade marginal, sem o status de profissão reconhecida, e aqueles que tinham a coragem de se confessar publicitários (ou propagandistas, como muitos insistiam em 
chamá-los) eram olhados com clara desconfiança. As primeiras agências de propaganda dignas desse nome somente então começavam a estruturar-se, nos padrões americanos. A maior delas era a Ayer, com um total de 20 funcionários, entre São Paulo e Rio de Janeiro. (...) Data da época aquela famosa tabuleta 'Esta firma não dá esmola nem anúncios' que muito dono de firma fazia questão de ter bem à vista em seu escritório. (REIS, 1990: 309)

Alguns mecanismos de legitimação foram acionados pelas agências, sobretudo a partir dos anos 1950, a fim de validar o campo e cultivar a "identidade sofisticada" do publicitário perante a sociedade como um grupo sério, diferenciado, hierarquicamente privilegiado. A investigação dos elementos que distinguem os produtores de anúncios permite interpretar o posicionamento de alguns papeis sociais e a relação da sociedade com estas mensagens persuasivas. É importante frisar que dentro de qualquer representação existe um universo complexo com múltiplas possibilidades que apontam para ramificações em seu interior. A representação funciona como uma espécie de modelo, uma "ancoragem", ideia utilizada por Serge Moscovici (2011), que assegura a vinculação com estruturas familiares, encaixa o conhecimento em modelos inteligíveis e concretiza os sistemas ou informações abstratos.

Os limites da identidade profissional do publicitário parecem ser uma determinação importante para o grupo, que procura manter e cultivar certos valores em torno da imagem do profissional, ainda que eles não se comprovem na prática. Vale ressaltar que o ambiente das agências é organizado em torno de inúmeras ocupações ligadas ao campo da administração, como: secretaria, transporte de documentos, gerência financeira, entre outros. Esta configuração é subordinada simbolicamente às funções que gravitam em torno da construção de mensagens para vender produtos e serviços. São funções tidas como complementares dentro da dinâmica da agência, que tem como principal finalidade produzir anúncios. Sendo assim, há uma reverência ou um respeito natural aos que estão diretamente envolvidos na atividade "nobre" da empresa. Zilda Knoploch (1980) registra que o conjunto de qualificações que define o perfil do publicitário, edificado por ele mesmo, destaca a existência de um "dom" próprio para o exercício da profissão. Os publicitários são aqueles que "nasceram para isso" e os que não possuem esse “dom” são o pessoal administrativo, 
burocrático. $\mathrm{O}$ “dom” passa a ser um mecanismo para manter a fronteira do grupo em relação aos demais (KNOPLOCH, 1980: 43).

Em sua pesquisa etnográfica com publicitários, Everardo Rocha (1985) elenca elementos fundamentais de auto valorização ou mecanismos de legitimação do grupo de publicitários - a diferenciação da categoria de vendedor, a genealogia heroica, o curso superior, o alto padrão de vida e o saber necessário para desempenho da profissão. Deste último, derivou a aplicação da ideia de bricoleur à análise da publicidade (Rocha, 1985). O bricoleur, tal como pensou Levi-Strauss (2012 [1962]), irá operacionalizar pequenos pedaços dispersos ou relacionar diferentes elementos para compor uma representação, dentro do princípio de que tudo pode ser aproveitado. Nesse processo, a criatividade e a inovação irão determinar as múltiplas aplicações práticas. Assim, Rocha (1985) relacionou o movimento intelectual da publicidade à noção de bricolagem. $\mathrm{O}$ saber publicitário é originado da apropriação de conhecimentos de outros setores, vindos da literatura, sociologia, psicologia, matemática, filosofia, cinema etc. De forma geral, qualquer experiência ou informação de outra ciência pode ser aproveitada na prática publicitária. Ao conceber um anúncio, o profissional buscará referências de várias disciplinas ou técnicas. Em suma, a publicidade pode reunir fragmentos do saber, pedaços de teorias, experiências casuais, resíduos aleatórios como instrumentos para a feitura de um anúncio. Tudo se presta para compor um conjunto individualizado.

Outro código de legitimação que os publicitários fazem questão de cultivar é a diferenciação de seu papel social com o do "vendedor". Embora a função de publicitário esteja intimamente articulada com o propósito de vendas, os profissionais se colocam em um patamar diferenciado, especial, elevado em relação ao vendedor comum que atende os clientes no varejo. A profissionalização instituída pelas agências fez com que os publicitários quisessem se descolar daquela imagem de vendedor, tão comum no início do século XX. Com o crescimento do campo, os profissionais procuraram demarcar balizas conceituais para assegurar a importância de sua posição, se colocando como hábeis articuladores de ideias, intelectuais que oferecerão as bases, os subsídios para as vendas acontecerem. Assim, o vendedor estaria "subordinado", "dependente" do publicitário para exercer seu ofício. A propaganda teria o poder de criar conhecimento, conduzir à compra e não simplesmente "vender". Há uma 
valorização da possibilidade de distribuir ideias, conceitos, hábitos e persuadir o público consumidor. O publicitário considera a sua atividade como uma prática intelectualizada e não técnica, por isso procura se desligar da venda direta.

O publicitário procura "subir um pouquinho o degrau de títulos" e "criar um charmezinho em torno da profissão". Sua venda não tem "mercadoria" na "prateleira". É um vendedor "mais profundo", "mais científico". Todas essas categorias têm um domínio comum de significação na medida em que criam limites, fronteiras bem nítidas, em relação aos vendedores, e definem o publicitário como uma profissão hierarquicamente superior. (ROCHA, 1985:41)

Quanto mais uma profissão ganha destaque e consideração pela sociedade, mais se espera que seus profissionais tenham trilhado um árduo caminho em busca de conhecimentos teóricos e empíricos até conseguir alcançar aquele posto de sucesso. Antes de um médico poder exercer efetivamente a medicina, por exemplo, se espera que ele tenha cumprido todos os pré-requisitos necessários para uma atuação tida como vital pelas coletividades modernas. Entre eles, estão a obrigação de anos de estudo em instituições credenciadas pelos governos e a preparação prática em laboratórios supervisionados, em geral hospitais ou clínicas. Desta maneira, a formação universitária é uma condição efetiva para a aceitação social e o respeito a uma determinada atividade.

A fundação do primeiro curso de publicidade do Brasil, - a Escola de Propaganda de São Paulo - em 1951, e a regulamentação da atividade publicitária, pela Lei Federal $n^{\circ} 4.680$, de 18 de junho de 1965, aprovada pelo Decreto $\mathrm{n}^{\circ}$ 57.690 , de 01 de fevereiro de $1966^{22}$, ajudaram a dar credibilidade social ao ofício. Embora não seja obrigatória, a necessidade de curso superior para o desempenho na área foi adotada pela maioria das agências como critério de seleção de seus funcionários. A medida tornou o estudo da publicidade uma condição relevante para a atuação no meio. A boa recompensa do profissional também estaria ligada ao seu grau de esforço para alcançar aquele posto.

Rocha (1985) destaca pontos elementares que constroem a imagem do publicitário a partir deste momento, como “ (...) alto salário e padrão de vida, a responsabilidade e função socioeconômica da publicidade, a história da profissão,

\footnotetext{
${ }^{22}$ www.planalto.gov.br - Disponível em : http://www.planalto.gov.br/ccivil_03/decreto/D57690.htm
} 
a passagem pelo aprendizado formal em nível superior e, o mais fundamental, o conhecimento necessário para desempenhá-la." (ROCHA, 1985:45). O mito da sofisticação é reforçado no cotidiano das agências e nas estratégias para impressionar os clientes. A maioria dos publicitários acredita que a roupa, os acessórios, o carro, os hábitos e os lugares que frequenta são fundamentais para projetar uma imagem bem sucedida no mercado. O jornalista Genival Rabelo descreve os hábitos do diretor da agência Standard no início dos anos 1950 como um rico empresário que possui carro do ano, motorista particular, cavalos de corrida, casa luxuosa com piscina (Rabelo, 1956). O modelo funciona como uma representação, uma identidade que o grupo buscou criar socialmente, e para a qual pouco importa sua efetiva realidade. Como coloca Moscovici (2011), representações sociais são "formas de conhecimento produzidas e sustentadas por grupos sociais específicos, numa determinada conjuntura histórica." (MOSCOVICI, 2011: 20). Nós experimentamos e percebemos o mundo através das representações materiais e imateriais produzidas em nosso tempo. O pensamento está condicionado às representações, linguagens e cultura na qual estamos inseridos.

Publicitários que participaram da história da publicidade nos últimos setenta anos, entrevistados para este estudo, também reforçaram que o estilo pessoal é uma valoração subjetiva do campo, quando perguntados sobre o peso da imagem e indumentária na representação da profissão. Para o publicitário Lula Vieira, "o profissional não gosta de passar despercebido e a roupa é a primeira forma de transmissão de uma mensagem ao cliente e aos seus pares. Em geral, carros e acessórios de luxo também são usados para compor uma imagem bemsucedida" ${ }^{\text {23 }}$. O Diretor de Criação José Guilherme Vereza lembrou que a ideia do alto padrão de vida foi um dos fatores que o levou à escolha da carreira e que o refinamento pessoal já era um critério de diferenciação da classe de publicitários desde seus tempos de estudante: "Na própria universidade, que tinha a habilitação de jornalismo e publicidade, já era possível perceber as escolhas dos alunos só de olhar." ${ }^{24}$ O famoso David Ogilvy (1993), no livro Confissões de um publicitário, acentua que seu carro é um Rolls-Royce e explica a importância de usar os produtos de seus clientes.

\footnotetext{
${ }^{23}$ Entrevista para a tese.

${ }^{24}$ Entrevista para a tese.
} 
Em visitas a algumas agências contemporâneas também podemos notar que os publicitários costumam se vestir de forma despojada, porém, alinhada com os modismos e referências de estilo atuais. Por isso, embora o tipo de vestuário nas agências seja mais casual, ele é absolutamente requintado. Além da indumentária, o publicitário coloca-se como uma pessoa criativa, sensível, atualizada, preocupada em se renovar intelectualmente, que lê muito, viaja constantemente, gosta de arte, frequenta centros culturais, cinemas e restaurantes badalados. Para o publicitário Mauro Matos: “O publicitário está vendendo um produto e uma imagem de alguma coisa, a primeira é a dele mesmo." ${ }^{25}$ Knoploch (1980) também evidencia a "aura de encantamento" em torno do publicitário:

Um sujeito bem vestido, engajado numa atividade excitante, "incrivelmente bemremunerada" e que, mais do que tudo, dá ao indivíduo a possibilidade de tornarse poderoso na medida em que passa a ser dono dos meios de influenciar pessoas, passa a ser "o sacerdote da nova religião: o consumismo" (...) Ser publicitário traz, para o jovem que ingressa na profissão, a possibilidade de "tentar criar uma consciência no povo, para que essa consciência chegue aos objetivos da gente". A propaganda é para o publicitário jovem "um grande, um tremendo fator de influência em hábitos". (KNOPLOCH, 1980: 39)

A responsabilidade social da publicidade, como uma instância que traz benfeitorias para a população, também é uma marca que o publicitário gosta de ligar à sua imagem. A publicidade pode ser vista como uma "educadora", definindo estilos de vida e trazendo um maior número de escolhas para a população. As mensagens que os anúncios carregam poderiam "ensinar" a viver com mais conforto ou seriam capazes de introduzir hábitos que melhorariam a qualidade de vida, como inspecionar o selo de qualidade da carne, ler o rótulo com a informação nutricional ou verificar a validade de um produto. Uma ideia que associa a publicidade como parte do aprimoramento das condições sociais ou do próprio desenvolvimento econômico e cultural de um povo, como colocam Armando Sant'Anna, Ismael Rocha Junior e Luiz Fernando Garcia (2009):

Torna-se parte integrante do processo do desenvolvimento econômico de um país. Sustenta o crescimento com a procura incessante de novos consumidores

\footnotetext{
${ }^{25}$ Entrevista para a tese.
} 
para produtos cada vez mais sofisticados. Dissemina a ideia de status conferida pela aquisição de objetos ligados a conforto e lazer. Considerada durante muito tempo simples auxiliar de vendedores que, por ela, poderiam atingir o consumidor em potencial, não identificável, a propaganda, pela evolução de suas técnicas, adquiriu nova dimensão, sendo capaz de influenciar e modificar hábitos de uma população em seu conjunto. (SANT’ANNA ET AL, 2009: 07).

A obrigatoriedade de diploma universitário, embora ajude a aglutinar prestígio e facilitar a conquista por uma vaga nas agências, ainda divide opiniões de profissionais e professores da área. O Redator Rafael Quintal ${ }^{26}$, de 22 anos, recém-graduado pela ESPM-SP, acredita que a formação universitária não foi determinante para a sua contratação na agência $D M 9 D D B$, a sexta maior do Brasil: "O que define o cargo é o portfolio da pessoa e não a formação acadêmica. O tempo de agência também não é determinante para uma promoção. Se conquistar vários leões seguidos, pode virar Diretor de Criação independentemente do tempo em que trabalha na agência." ${ }^{27}$. O Diretor de Criação da África Rio Otto Pajunk considera o diploma universitário totalmente “irrelevante" para a atuação no campo: "Eu pelo menos, quando entrevisto alguém, nunca peço para ver diploma, não quero nem saber a faculdade em que o candidato se formou" 28 .

A professora de publicidade da PUC-Rio Mariana Palmeira também não qualifica como necessária a passagem pelo ensino superior, mas acredita que a universidade oferece uma contribuição abrangente, mais humanística e menos técnica: "O diferencial da universidade para o campo da comunicação está ligado ao desenvolvimento do pensamento, do senso crítico e da ética. Acredito que os principais ingredientes para a atuação bem sucedida nesse campo são a informação, a cultura adquirida ao longo do tempo, as referências que o profissional busca para exercer seu ofício, o conhecimento profundo do seu público, assim como o entendimento profundo do que o cliente realmente quer quando contrata seus serviços" ${ }^{29}$. A professora Tatiana Siciliano, coordenadora do curso de publicidade da PUC-Rio, que acumula quinze anos de experiência profissional na área de pesquisa de mercado, avalia que a passagem por algum

\footnotetext{
${ }^{26}$ Entrevista realizada em 31/03/2015, durante a visita à sede paulista da agência $D M 9 D D B$.

${ }^{27} \mathrm{O}$ entrevistado se refere aos Leões de Ouro, Prata e Bronze, principais prêmios do Festival de Publicidade de Cannes, o mais importante da publicidade mundial.

${ }^{28}$ Entrevista para a tese.

${ }^{29}$ Entrevista para a tese.
} 
curso de humanas ou ciências sociais é bem interessante para o desenvolvimento da prática profissional: "A universidade pode trazer uma visão sobre os conceitos da atividade e uma formação mais teórica sobre o campo da comunicação, que possibilite o futuro profissional refletir de uma forma mais ampla sobre o seu papel social e poder se adaptar criativamente às mudanças" ${ }^{\text {,30 }}$. A professora de publicidade da PUC-Rio Claudia Brutt, que atua no mercado de publicidade desde meados dos anos 1970 com passagens por agências como McCann e JWT, pondera como desejável a passagem pelo curso superior uma vez que a introdução ao universo profissional é facilitada pela massa de conhecimento formada pela universidade, que estimula o pensamento analítico do aluno. ${ }^{31}$

Mesmo com resistências quanto à obrigatoriedade do diploma, não há dúvidas que a introdução do estudo da publicidade em nível superior trouxe uma importância e um aprimoramento ao setor. Segundo Rocha (1985), essa é uma das formas mais importantes de elevação de status de uma profissão. Não por acaso, as faculdades de comunicação de todo o Brasil são muito demandadas pelos estudantes, e o curso ocupa boa posição entre os mais procurados no vestibular. Em geral, os publicitários recomendam e só aceitam contratar nas agências, candidatos com formação universitária. A ambiguidade parece residir em torno da separação entre teoria e prática, que tanto insiste em partilhar opiniões de acadêmicos e profissionais. $\mathrm{O}$ diploma seria antes um mecanismo de legitimação que ampliará os conhecimentos do aluno de forma abrangente, do que um atestado decisivo para o exercício diário da profissão. Armando Sant’Anna, Rocha Júnior e Garcia (2009) sublinham que um bom publicitário deve ter uma base sólida, conhecer princípios e a estrutura da comunicação, noções de sociologia, antropologia, filosofia, além de acompanhar as mutações sociais e o ritmo dos negócios.

Além do lugar que as escolas de comunicação ocupam para a construção da representação social do publicitário, Rocha (1985) destaca ainda a "história" da profissão como um artifício que também compõe esse repertório identitário. Neste sentido a história não está propriamente relacionada à longevidade e sim a uma sucessão de símbolos que dão forma à sua genealogia. Para uma profissão ser histórica são necessários elementos como: formação de uma identidade própria,

\footnotetext{
${ }^{30}$ Entrevista para a tese.

${ }^{31}$ Entrevista para a tese.
} 
eventos fundadores, fatos pioneiros que marcaram o nascimento de seu campo e sua validez ou eficiência perante a sociedade. As referências históricas justificam e embasam a trajetória do campo, bem como engrandecem as suas finalidades atuais. Quanto mais antigas forem as apropriações históricas, mais respeito e aceitação o campo terá (Rocha, 1985). Por isso é muito comum profissionais reforçarem a ideia de que a publicidade remonta tempos pré-históricos. Muitos gostam de se referir a longínquos símbolos culturais como maneira de comprovar a extensa trajetória da profissão. Assim, consideram que escritas em cavernas já eram uma forma de anunciação ou papiros egípcios conservados em museus são provas materiais que indicam a existência de publicidade na Antiguidade (Malanga, 1976). Vale frisar que este estudo considera a narrativa publicitária um produto social criado a partir de certas condições observadas no tempo modernocontemporâneo, como economia baseada em preceitos capitalistas, mercado consumidor e meios de comunicação massivos.

Em geral, os publicitários costumam exagerar a complexidade de seus trabalhos como mais uma estratégia de valorização de suas práticas. Os estudantes de comunicação, por exemplo, consideram muito difícil conseguir uma vaga em uma agência renomada, como fica claro em depoimentos de alguns informantes, todos alunos de publicidade da PUC-Rio e da ESPM-SP. "Meu sonho é trabalhar em uma grande agência, mas existe mais demanda por vagas do que oferta. Não é muito fácil conseguir uma vaga, principalmente na área específica que você quer trabalhar", opina um estudante de publicidade da PUC-Rio. "A gente tenta se preparar para encarar uma agência através dos estágios e laboratórios dentro da faculdade, mas é muito difícil entrar pro mercado de trabalho" ${ }^{32}$, completa a estudante de publicidade da PUC-Rio. "A concorrência é tanta que às vezes não conseguimos mostrar nossos talentos para os empregadores. Neste sentido, as redes sociais ajudam a divulgar o portfólio", comenta uma estudante da ESPMSP. "O mercado de agências só consegue absorver parte dos estudantes. Por isso, muitos acabam optando por outros caminhos no mundo empresarial”, analisa um aluno da ESPM-SP. Projetar no mercado a ideia de dificuldade de acesso ao campo e do requinte intelectual necessário para o seu desenvolvimento faz parte de certa "dramaturgia" para elevar o prestígio da profissão.

\footnotetext{
${ }^{32}$ Entrevistas realizadas em 31 de março de 2015 na ESPM-SP e em 13 de abril de 2015, na PUCRio.
} 
O uso de jargões que privilegiam palavras estrangeiras é outra prática que agrega importância ao trabalho do publicitário. Assim, uma reunião livre de ideias entre o grupo ganhou a alcunha de brainstorming, o conjunto de informações para o desenvolvimento da campanha se tornou um briefing, a arte gráfica ou apresentação da campanha receberam a rebuscada denominação de layout. São recursos que acentuam o status e atribuem grandeza às ações do setor. Para Armando Sant Anna (1973), o trabalho do publicitário é tão significativo que se tornou a “(...) mola do desenvolvimento nacional.” (SANT'ANNA, 1973:46), uma vez que o desenvolvimento de um país estaria associado ao aumento de sua produção e seria a propaganda o principal recurso para estimular o consumo.

\section{2- A agência em ação: estrutura e funcionamento}

Para encadear as atividades do processo cooperativo de produção de anúncios, departamentos conectados e, ao mesmo tempo autônomos, foram organizados. Nomenclaturas próprias e incumbências particulares de cada setor também foram traçadas discriminatoriamente para trazer reconhecimento e ordenação ao campo. A partilha de tarefas e o grande número de departamentos em uma agência enfatiza o caráter intricado e multifacetado da produção de anúncios. As divisões espaciais sugerem relações de poder e estabelecem a ordem hierárquica da função em cada ambiente profissional. Essa estrutura pode ser mais ou menos sofisticada, dependendo do tamanho da empresa e do número de clientes que ela atende. Cada agência também tem autonomia para agrupar os departamentos e as funções dos profissionais seguindo critérios próprios, mas as divisões traçadas (em geral, Atendimento, Planejamento, Mídia e Criação) pelas agências norte-americanas desde o início do século $\mathrm{XX}$ prevaleceram como modelos de estrutura interna formal para a maioria das agências de propaganda ao redor do mundo. Os departamentos são os locais onde as mensagens são concebidas, planejadas e distribuídas aos meios de comunicação.

O primeiro deles é o Atendimento, segmento responsável por fazer todo o contato com o cliente. Seus integrantes atuam como gestores, responsáveis pela 
rentabilidade da conta, já que concentram dados relativos a faturamento, custos e gastos internos. O profissional de Atendimento é a porta de entrada na agência para novos negócios, por isso acredita-se que devem ser comunicativos, simpáticos e bem vestidos para impressionar os clientes, além de informados sobre as características do negócio, tanto o próprio, quanto o do virtual cliente, e os hábitos dos consumidores. Ademais, são os responsáveis pela imagem da agência no escritório do cliente e no mercado empresarial como um todo. O "diretor da conta" ou "gerente de contas", e seus "assistentes de contato", darão o tom do trabalho a ser desenvolvido, uma vez que serão os intérpretes das vontades do cliente para o restante da agência, bem como levarão de volta as sugestões pensadas para o anúncio. São eles os encarregados de redigir o briefing e checá-lo com o cliente para evitar erros. A parte burocrática e o acompanhamento do trabalho que a agência desenvolve também são parte das obrigações destes profissionais (Sant'Anna et al, 2009). Os "supervisores de atendimento" geralmente atuam apenas nas situações mais importantes, como apresentações de campanhas aos clientes, ou definição dos objetivos de marketing da conta (Knoploch, 1980). Antes de levar o trabalho ao cliente, os profissionais deste departamento costumam ouvir as defesas dos setores envolvidos para compará-las aos objetivos do anunciante.

O nome atendimento é criticado no meio publicitário brasileiro por se confundir com "atendente", uma função que não exige os requisitos necessários da categoria. Nos Estados Unidos, a função é denominada de Account Handler ou Account Manager, que podemos traduzir por "gerente de contas", nomenclatura que enfatiza um estilo profissional, que o aproxima do imaginário, altamente prestigiado, dos "grandes executivos" empresariais.

O setor de Planejamento é o que irá traçar planos de marketing, estratégias de comunicação e avaliar caminhos para levar uma solução que resolva o problema do cliente. Seus integrantes, geralmente chamados de Planners, fornecem ideias para outras áreas, tendo um diálogo próximo com o setor de Criação. A partir de análises do mercado e de pesquisas sobre o produto ou serviço e seu universo de consumidores, o profissional procura desenvolver conteúdos que fundamentem os anúncios, contribuam com a construção da marca e identifiquem oportunidades e ameaças que ajudem a posicionar a empresa. $\mathrm{O}$ Planejamento rege as ações, o processo decisório sobre o que e como determinada 
atividade deve ser feita. O Diretor de Planejamento dá as diretrizes da campanha de acordo com os objetivos do cliente, além de dividir a verba orçamentária para a produção do material e o percentual que será investido na mídia. Acredita-se que este profissional deva ter liderança aliada a uma boa capacidade de relacionamento, a fim de gerar confiança e fidelização do cliente (Lupetti, 2009). A imagem projetada se aproxima de uma espécie de grande "pensador", capaz de planejar ou "teorizar" todo o processo.

$\mathrm{Na}$ área de Mídia, os profissionais irão investigar as características de cada meio, para indicar o melhor veículo para a propagação de determinado anúncio, além de fazer contato com os canais de comunicação para a compra de espaço ou tempo para inserção ou transmissão dos anúncios. Estuda-se também a posição, formato ou volume que a mensagem deverá ter, assim como fiscaliza e controla todo esse sistema de distribuição, averiguando o tamanho da publicação, quantas vezes ela irá aparecer, qual espaço vai ocupar em uma página impressa ou em que horário será apresentada, no caso de rádio e televisão. Os "Mídia", como são chamados, operam a seleção dos veículos de acordo com definições de públicoalvo (levando-se em conta fatores como classe-econômica, escolaridade e faixa etária) e os objetivos de marketing do cliente, trabalhando em estreita ligação com os departamentos que desenvolvem pesquisas sobre as características do mercado e sobre os consumidores. Institutos de pesquisas como Ibope $^{33}$ e o Mídia Dados ${ }^{34}$ também são importantes ferramentas que ajudam a levantar estatísticas para conhecer o comportamento do mercado publicitário e a importância de cada meio. Em suma, são os Mídia que vão determinar qual o veículo - jornal, rádio, televisão, revista, mala direta, outdoor, internet - é mais adequado aos objetivos de cada campanha (Knoploch, 1980). O "planejamento de mídia" deve considerar as instruções da campanha e as recomendações dos anunciantes, incluir dados demográficos, potencial de consumo, concorrência, hábitos e perfil do públicoalvo, estudos de penetração dos meios e a relação custo-benefício (Lupetti, 2009).

O profissional deve ser familiarizado com as ciências humanas e exatas, pois precisará entender, tanto sobre comportamento psicológico humano, quanto

\footnotetext{
${ }^{33}$ O Ibope é a maior empresa privada de pesquisas da América Latina e a $13^{\text {a }}$ do mundo. No Brasil, a empresa é bastante conhecida pela medição de audiências da televisão e das pesquisas eleitorais de opinião pública. www.ibope.com

${ }^{34}$ Mídia Dados, editado pelo Grupo de Mídia de São Paulo, é um estudo profundo com informações demográficas, mercadológicas e comerciais do mercado brasileiro e sul-americano de mídia. www.gm.org.br
} 
sobre cálculos, cruzamento de dados e logística. O Mídia tem como função primordial tornar a mensagem comercial acessível para o público consumidor potencial. Alguns clientes costumam preparar um briefing específico só para a área de Mídia. Analisar o perfil da população local e da região onde o produto estará em circulação também são atividades fundamentais para o sucesso das estratégias. O controle, chamado checking, de todas as inserções publicitárias nos meios ou a verificação do correto uso da campanha, exatamente conforme o que foi planejado, completam o conjunto de serviços que este departamento oferece. As grandes agências costumam contratar institutos de verificação para fazer esta minuciosa averiguação e fornecer os dados para os clientes (Lupetti, 2009).

Com a complexidade e a fragmentação dos meios de comunicação, exigese que o profissional de mídia não apenas proponha dispositivos para que a mensagem chegue ao público-alvo, mas que tenha um conhecimento específico e profundo das diversas plataformas comunicativas e suas formas de recepção. A escolha dos veículos passou a ser mais seletiva e direcionada. O lugar do Mídia, geralmente é identificado como eminentemente "exato" e "técnico", no limite, se aproximando da imagem de um "cientista".

A Criação é, desde os primeiros momentos de organização do campo da publicidade, o departamento mais prestigiado, tido como a alma da agência. Não por acaso, são comuns as referências dos publicitários aos poetas, escritores e artistas que fizeram anúncios antes das agências existirem. O setor exerce muito fascínio entre aqueles que almejam alcançar estes desejados e concorridos postos. Os "criadores" das agências são responsáveis pelas ideias, transformadas em textos e imagens, que serão utilizadas nas campanhas, têm a missão de despertar desejos de compra, fortalecer marcas em relação aos competidores e edificar uma imagem pública favorável. O glamour que rodeia este departamento, muitas vezes esconde a enorme pressão e a rotina estressante a que os profissionais estão expostos. Para Stalimir Vieira (2000), a curiosidade, a entrega, a capacidade de se arriscar, desejo de aprender, inquietação, propensão ao questionamento, convivência amigável, observação são atitudes esperadas dos “criativos".

A Criação está interligada a todas as outras seções da agência. A partir dos anos 1960 foi comum termos "duplas de criação" atuando neste setor, sendo um Diretor de Arte e um Redator que trabalham em parceria para achar soluções para os anúncios. Além destes, também temos produtores de rádio, televisão e cinema 
e produtores gráficos operando neste departamento. Em algumas agências, a Produção aglutina tantos profissionais e possui uma multiplicidade de tarefas tão grande que forma um departamento próprio, separado estruturalmente da área da Criação.

O Redator é o responsável por escrever textos, títulos, slogans e definir os roteiros de gravações dos comerciais, spots e jingles ${ }^{35}$ junto aos produtores. A concepção destas linguagens será ancorada no briefing que o anunciante forneceu e na capacidade do Redator em expressá-lo de forma adequada. Sua função consiste em conhecer os métodos para persuadir ou convencer o consumidor a comprar um produto ou serviço. Na publicidade, as técnicas de redação estão, na maioria das vezes, ligadas a imagens. $\mathrm{O}$ texto é complementar à imagem e viceversa. Por isso, as "duplas de criação" atuam em conjunto.

O Diretor de Arte vai cuidar de toda a parte gráfica, visual das peças, incluindo esboços de ilustrações em harmonia com os textos, storyboards ${ }^{36}$, acompanhamento de filmagens, direção de fotos, supervisão da montagem dos anúncios e controle dos materiais e das impressões finais (Knoploch,1980). Sua preocupação é com a estética e a harmonia dos elementos. É o Diretor de Arte quem cria, organiza e diagrama a estrutura física do anúncio na página do veículo, impresso ou on-line, alinhando o título com a imagem e o logotipo da campanha. Para isso, ele precisa ter conhecimentos de design, computação, softwares de edição de imagens, estudar as cores, combinações e seus significados (Lupetti, 2009).

A partir da campanha idealizada pelos Redatores e Diretores de Arte começa a atuação da Produção. Os Produtores adaptam e planejam as mensagens para o veículo que pretendem utilizar, providenciando todos os recursos necessários para a execução do anúncio. É o profissional que vai finalizar as ideias da Criação, funcionando como um assessor técnico deste setor. Se o desafio é a concepção de um folheto, por exemplo, o Produtor Gráfico concretizará um número específico de folhetos que serão distribuídos pelo cliente, fornecerá o desenho, ilustração ou foto. Se preciso, também contratará um fotógrafo e

\footnotetext{
${ }^{35}$ Spot é a peça publicitária gravada para veiculação no rádio, podendo ou não ter efeitos sonoros e música de fundo. Não deve ser confundido com Jingle que utiliza principalmente a música como recurso para propagação da mensagem.

${ }^{36}$ Ilustrações ou série de gráficos com imagens que permitem uma pré-visualização da sequência de um filme, anúncio ou programa.
} 
modelos, escolherá o tipo de papel, sua gramatura e a melhor técnica de impressão. A fabricação de cenários, locações, seleção de personagens, contratação de atores ou músicos, editores, cinegrafistas, além da edição dos filmes, mixagem de áudios, efeitos sonoros, checagem de direitos autorais também faz parte do enorme número de incumbências do chamado Produtor de Rádio, TV e Cinema ou RTVC. Em algumas agências esse trabalho é desempenhado pelo próprio Diretor de Arte ou através de contratações terceirizadas (Lupetti, 2009). O Produtor será uma importante peça na intermediação do Departamento de Criação com os de Atendimento, Mídia e fornecedores.

Podemos ter ainda o Revisor, responsável pela checagem e avaliação de todo material textual, o Arte-finalista, que vai fiscalizar as peças finais antes do envio para gráficas ou produtoras de vídeo, a Pesquisa, área que abastecerá a agência como um todo com levantamento de dados ou de audiência. Juntos, estes profissionais são os grandes responsáveis pelos conteúdos e formas dos produtos finais das agências. O Diretor de Criação coordena todas as campanhas e profissionais deste departamento. Em algumas agências, ele também participa do atendimento ao cliente, o que possibilita um acesso direto a informações importantes para o desenvolvimento das campanhas. Um "artista criador" é a idealização dominantemente desejada no imaginário em torno das funções típicas deste departamento.

Para o publicitário José Guilherme Vereza, o setor da Criação é o "coração da agência de publicidade, sua parte mais importante. Uma agência pode ser formada apenas com uma área de Criação, sem nenhum outro departamento. ${ }^{, 37} \mathrm{O}$ publicitário Mauro Mattos corrobora esta visão: “A Criação é a alma de tudo. Sem a Criação você não faz agência nenhuma e com Criação e sem o resto você faz alguma coisa., ${ }^{, 38}$.

Atendimento, Planejamento, Mídia e Criação são as quatro grandes divisões dentro das agências e os principais responsáveis por diferenciar uma empresa de publicidade dos demais empreendimentos do universo administrativo. No entanto, existem outras funções complementares como Fotografia, Pesquisas, Tráfego e Gerenciamento de projetos. Cada uma destas ramificações aglutina

\footnotetext{
${ }^{37}$ Entrevista para a tese.

${ }^{38}$ Entrevista para a tese.
} 
profissionais que concebem o trabalho, o executam, fornecem equipamentos e materiais e ordenam os canais de divulgação para o público que consumirá a mensagem. Juntos, esses setores formam uma rede cooperativa determinante para o evento do anúncio. Estes elos colaborativos seguem uma rotina de afazeres definida pelas convenções do campo publicitário. Ou seja, para que um anúncio se materialize, as agências seguem uma cadeia de tarefas interpostas em fases ou processos de produção regrados.

Assim, a elaboração de um anúncio tem início no atendimento ou contato. Como vimos, algumas empresas adotam o chamado "atendimento integrado", em que profissionais da Criação também participam da relação com o cliente. Assim que uma empresa fecha o negócio, a agência passa a atendê-la com exclusividade em sua área de atuação. Por princípios éticos do campo, uma agência que consegue a conta de uma montadora de carros, por exemplo, não pode trabalhar simultaneamente para algum concorrente deste setor. Se, por ventura, isso vir a ocorrer, a agência deve abrir mão de um dos clientes.

A partir das primeiras informações trazidas pela área de Atendimento, são detalhadas as características e utilidades do produto ou serviço que se pretende lançar. Em seguida, o Planejamento entra em ação para formular os objetivos da campanha, determinar prazos, orçamento e critérios a ser seguidos, de acordo com a conceituação elaborada para a campanha. O Planejamento também irá dimensionar o tipo de mercado e público consumidor, local e tempo das ações em cada mídia, levantará pesquisas, referências, hábitos relacionados e fazer demonstrações práticas. De posse deste elaborado estudo, a equipe de criação se reúne para começar a pensar uma nova campanha. Esta espécie de reunião para pensar os caminhos que o anúncio deve seguir recebe o nome de brainstorming. Neste livre levantamento de ideias cada participante pode trazer informações acerca do produto ou serviço ou tecer considerações aleatórias, sem nenhum tipo de compromisso ou censura. O objetivo desta fase é obter alternativas, possibilidades criativas e de bom gosto (Knoploch, 1980).

$\mathrm{Na}$ etapa seguinte, as melhores ideias serão confeccionadas pelos profissionais de cada especialidade. Diretores de Arte cuidarão da parte visual do anúncio, os Redatores escreverão os textos e os Produtores fornecerão as condições para as gravações dos anúncios para rádio, televisão ou cinema. Assim que a campanha fica pronta, o desafio está em apresentá-la ao cliente. A "venda" 
das ideias ao anunciante é um dos momentos mais importantes na dinâmica das agências. Nesta ocasião, o cliente pode se mostrar resistente ou mesmo se colocar contra o trabalho apresentado. Por isso, esta fase é sempre carregada de expectativas e inquietações. Os profissionais se preparam com afinco, estudam os elementos da campanha, traçam estratégias de persuasão e revestem de formalidade o encontro. Supervisores de atendimento, contatos, equipe de Criação e até a direção geral da agência podem participar desta apresentação, que consiste na demonstração de layouts ou de roteiros de filmes com uma descrição exata dos objetivos e formas de execução da campanha. No meio publicitário, acredita-se que os discursos de "vendas" devem ser envolventes e sedutores para conseguir atingir a emoção do cliente, colocando-o a favor da campanha desenvolvida. Outras campanhas alternativas também podem ser discutidas com o cliente. Aquela que o anunciante aprovar é que será desenvolvida.

Com a concordância de uma campanha, tem início a elaboração das peças publicitárias. Os Redatores e Produtores começam a gravar spots e jingles. Filmes para a televisão e cinema são coordenados por RTVCs ou Diretores de Arte. Empresas terceirizadas podem ser contratadas para a incrementar alguns serviços, como artes gráficas e fotografia, no caso da agência não possuir determinado setor. Um rigoroso controle de qualidade é aplicado nos anúncios impressos e filmados, que podem ser refeitos inúmeras vezes até que se consiga o resultado pretendido. O Diretor de Criação, com a ajuda de Produtores, supervisionará todo o desfecho das ações, escolherá os tipos de fontes, a disposição das frases no espaço impresso e a edição final no caso de filmes. Com as peças prontas, é feita uma nova apresentação ao cliente. Agora não mais perante o contratempo de transformar conteúdos e formas, apenas para demonstrar o trabalho concluído, a fim de corrigir pequenos erros antes do lançamento da campanha. Neste encontro, o cliente assina os pedidos de compra de tempo e espaço nos veículos de comunicação. A Mídia prossegue então com as ordens de compra. Nos contratos com os meios estão especificados o número de repetições dos anúncios, dias e horários, a quantidade de inserções em revistas ou jornais, com as páginas referidas e, no caso de outdoors, os prazos e locais de exposição (Knoploch, 1980).

Em geral, o ambiente das agências também é composto de modo que o trabalho em equipe seja destacado como uma marca imediata daquela identidade 
profissional. Não à toa, os anúncios - se e quando assinados - o são, não por indivíduos, mas com o nome da agência. Poucas são as paredes que dividem os espaços arquitetônicos. Funcionários se acomodam em torno de mesas interligadas e dispostas em um grande salão comum. As salas dos diretores, executivos ou donos da agência ficam localizadas no entorno deste escritório coletivo, separadas por estruturas de vidro e portas, que costumam ficar abertas. Esta diferenciação espacial demarca territorialmente as hierarquias e graus de poder. No entanto, a comunicação entre os diferentes setores é facilitada pela disposição fluida dos elementos arquitetônicos, que permite a circulação dinâmica dos conteúdos e trocas de todas as partes envolvidas na produção de um anúncio. Reuniões com clientes são realizadas em salas mais reservadas, para que o barulho do salão principal não dificulte a negociação e a apresentação de projetos. Cores fortes e adornos modernos são sempre incorporados à decoração, além de sofás e pufes que proporcionem conforto para a geração de ideias e também diferenciem a agência de um escritório convencional. Agências mais modernas costumam colocar mesas de sinuca ou tênis de mesa como parte dos arranjos. O ócio e os jogos em equipe são vistos como estímulos à criatividade. Um publicitário pode ter uma ideia extraordinária para o desenvolvimento de uma campanha no meio de uma competição no horário do expediente. Atividades associadas ao lazer e ao tempo livre fazem parte da mítica em torno da profissão. Cultiva-se o imaginário de que o publicitário pode trabalhar o dia todo com os pés em cima da mesa e ter bons resultados apenas com o "dom" da imaginação, uma capacidade intrínseca e divina de "criar". Seria este "dom” o responsável por garantir uma rotina de trabalho divertida e assegurar altos salários.

Cartazes ou quadros com algumas propagandas de sucesso da organização costumam ser expostos nas paredes desde o hall de entrada. As grandes agências, que já conquistaram importantes premiações, como Leões de Ouro ou Grand Prix no Festival de Cannes, fazem questão de exibir seus troféus em locais visíveis. As premiações são uma maneira de impressionar os anunciantes, garantir a confiança dos mesmos no trabalho da agência, bem como ostentar um símbolo de poder. No conjunto, a imagem projetada é a de um ambiente contemporâneo, de ideias arejadas, mentalidade ousada e práticas integradas. 


\section{3- Redes de interação das agências}

A interligação entre setores confere e reforça o espírito de ação coletiva, estimulando a edificação de identidades em torno de valores que prezam as convenções partilhadas pelo campo da publicidade. O interacionismo também aguça um senso de pertencimento àquele empreendimento e reforça o efeito de recompensa que cada agente sente por ter contribuído de alguma forma para o produto final. A troca dependente entre as partes produz um sentido comum do valor daquilo que é produzido coletivamente (Becker, 1977a).

Na medida em que um mundo tiver constituído uma rotina própria e estabelecido maneiras convencionais de se desempenhar as atividades a que seus membros habitualmente se dedicam, as pessoas poderão participar na qualidade de membros plenamente competentes, isto é, que sabem exatamente como fazer bem e facilmente tudo que tem que ser feito. (BECKER, 1977a: 24)

Nestes termos, podemos observar dentro das agências aquele tipo de profissional que Becker (1977a) classificou como integrado. Os profissionais integrados são aqueles que produzem rigorosamente de acordo com as convenções vigentes naquele mundo. As agências organizaram as identidades e ações do campo da publicidade, requisitaram todos os materiais, instrumentos e condições de difusão para que anúncios pudessem ser produzidos e posteriormente veiculados, bem como condicionaram a elaboração do mesmo em torno de preceitos exclusivos e acabados. O profissional integrado é aquele que se encaixará nesta estrutura montada para a produção publicitária. Ele não usará recursos próprios ou optará por saídas distantes dos elementos disponibilizados em seu mundo. Assim, os integrados reforçam as convenções que legitimam o campo, conseguindo atingir um público que entende, aprecia e consome suas narrativas. São profissionais que conhecem, se adaptam e usam as convenções e atividades padronizadas que regulam o funcionamento de seu mundo. A forma satisfatória com que desempenham seu trabalho reflete em todos os aspectos da produção, desde o emprego de materiais, formas, conteúdos, apresentação, tamanho e financiamento de um projeto. $\mathrm{O}$ fato de os integrados se conformarem às convenções faz com que os anúncios sejam produzidos de forma mais rápida e fácil, o que não quer dizer que as dificuldades não existam, apenas que as 
convenções foram pensadas tentando minimizá-las ao máximo (Becker, 1977a). A existência de uma rotina não significa necessariamente que não haja variações, mas a cadeia imposta na estrutura capitalista como um todo privilegia muitas vezes a quantidade. Assim, o aprimoramento das convenções é incorporado lentamente, sempre que não prejudicar o ordenamento da produção sucessiva.

Dentro desse modelo rotineiro de ação, algumas das funções desempenhadas na agência se destacam e são encaradas pelos participantes do mundo publicitário como verdadeiros dons ou vocações extraordinárias, como em relação ao desenvolvimento de ideias na área de Criação. Os membros deste setor são considerados agentes produtores de inovações e rupturas marginais, que não chegam a violar as convenções, não rompem a ação coordenada, mas possuem capacidade para renovar os ciclos, ainda que ligeiramente. Há toda uma mística que ronda a Criação, e atribui a seus integrantes habilidades raras ou capacidades sensitivas merecedoras de respeito. Os Diretores de Criação são comparados a grandes artistas, e todos os outros profissionais são vistos como complementares, servindo de apoio para o trabalho de criação. Becker (1977), referindo-se ao mundo artístico, coloca que o ato, cuja realização marca uma pessoa como artista, é uma definição por consenso, uma vez que o trabalho final em si só foi possível graças ao trabalho de outras pessoas, desde a fabricação de materiais, instrumentos, até a preparação ou veiculação de um produto cultural: "O artista, assim, trabalha no centro de uma ampla rede de pessoas em cooperação, cujo trabalho é essencial para o resultado final. Onde quer que ele dependa dos outros, existe um elo cooperativo." (BECKER, 1977: 209). A relação com a cadeia de colaboradores define os limites do que pode ser produzido, uma vez que a dependência das diferentes camadas de ações do sistema restringe a atividade ou artefato final pelas capacidades de produção dos elos cooperativos. Desta forma, de nada adianta o Departamento de Criação de uma agência inventar uma campanha que não se ajuste aos recursos existentes nos outros setores, esteja fora da competência dos executantes ou do orçamento previsto pelo Atendimento. Quando vai além das habilidades da instituição, a obra não é concebida ou lançada. Em um sistema de ação colaborativa, os profissionais têm que acomodar suas concepções aos mecanismos e faculdades disponíveis, aceitando possíveis restrições, ou terão que gastar tempo e energia para providenciar ou capacitar novas formas de ação. A escolha pela produção sem o uso dos artifícios existentes 
requer um investimento adicional naquele trabalho. Muitas vezes, isso resultará em disputas de poder interno ou em tensões em relação ao cliente. Knoploch (1980) coloca que a Criação na agência é sempre definida em oposição ao Atendimento. Há uma supervalorização da Criação em relação ao Atendimento e uma neutralização do setor de Mídia. A diferenciação com o setor do Atendimento é feita, principalmente, com base no argumento de que existe um talento especial do criador. A discrepância central entre o publicitário e a produção artística em geral é que a arte publicitária não é livre, existe uma finalidade de comunicação muito específica e que precisa ser cumprida a fim de persuadir pessoas a comprar alguma coisa.

O Atendimento é visto como uma área diretamente ligada com o propósito de vendas, com o aspecto comercial dos negócios, uma vez que é o elo de ligação entre o cliente e a agência. Deste modo, a Criação também gosta de se colocar como um departamento que não se submete ao caráter "depreciativo" comumente associado às vendas. Para os profissionais deste setor, a propaganda estaria ligada à criação de conhecimento. Assim, se a ideia for boa, ela conduzirá o consumidor a experimentar o produto. $\mathrm{O}$ ponto de vista valoriza a nobreza da atividade, o caráter intelectual da prática, desconectado da venda direta. Ou seja, a propaganda, teria a função de ajudar as pessoas a conhecer melhor os artefatos e serviços disponíveis no mercado, seria uma espécie de "benfeitora" social, uma instância de utilidade pública: "Se a propaganda vender, o profissional de propaganda deixa de ser aquilo que idealiza: um artista, que possui um dom especial, uma criatividade e uma sensibilidade profundas que são usadas em benefício de uma coletividade." (KNOPLOCH, 1980: 40).

Vale enfatizar que em todas as entrevistas realizadas para este estudo, os publicitários também realçaram a Criação como a área mais importante e indispensável da agência. A identificação recorrente com a figura do artista também foi observada nas entrevistas, mesmo sem o uso da pergunta direta. Segundo os profissionais, a hierarquização entre os departamentos se dá pelo Departamento de Criação ser o fabricante do principal produto da agência: a ideia. "Sem a ideia, as vendas não acontecem. Os outros departamentos não participam diretamente da concepção das ideias", resume o publicitário Lula Vieira ${ }^{39}$.

\footnotetext{
${ }^{39}$ Entrevista para a tese.
} 
No campo profissional, as definições são deliberadas pelos grupos de poder, ações simbólicas das hierarquias dominantes sobre os demais. Os interesses também são diferentes dentro do processo de produção cooperativo. O capitalista ou o dono do negócio têm interesses diferentes aos de seus funcionários que, na maioria das vezes, querem realizar adequadamente suas atribuições, com a finalidade de ganhar um salário e o reconhecimento que garanta sua promoção ou estabilidade no emprego. Os interesses financeiros em geral se diferem dos interesses artísticos, são antagônicos por se tratar de ordens materiais e subjetivas, respectivamente. Contudo, as disputas são rotativas e mudam de posição a todo o momento dentro de uma instituição. Knoploch (1980) destaca que, ora os profissionais de um setor se colocam como rivais de outro, ora se unem e criticam um terceiro segmento e assim por diante. A autora associa o processo ao sistema político das sociedades nuer, descrito pelo antropólogo Evans-Pritchard. Nos códigos nuer, a tribo é demarcada por segmentos e oposições entre eles. O comportamento de cada habitante nuer é definido de acordo com os conflitos políticos travados entre os setores, ou seja, classificações internas são operadas por um conjunto de identificações a partir de disputas. Assim, os grupos se unem para lutar por seus princípios frente a outras categorias, e formam suas identidades com base nessas associações dadas por rivalidades. No entanto, são os níveis de poder dentro da tribo que distinguem operacionalmente os exercícios ou as formas de ações conjuntas. A ideologia é balizada a partir da hierarquia montada em oposição ao grupo inferior, um poder que não pode ser exercido sem a outra metade da relação. O sistema, portanto, ressalta o valor da relação e do encadeamento dos integrantes para a manutenção da composição política e dos mecanismos de controle sociais.

Nesse sentido, mesmo com os interesses discrepantes dos atores sociais dentro de uma empresa, a colaboração de muitas partes da instituição é necessária para a produção acontecer. As convenções em geral ditam os direitos e obrigações de cada parte. São os termos pelos quais as identidades e as redes de cooperação serão estabelecidas. Por isso, a necessidade de atividades profissionais concatenadas dentro de uma agência de publicidade é fundamental para a produção dos anúncios. Os acordos que definem cada funcionalidade não são tomados diante de uma nova ocasião ou necessidade. Ao contrário, as definições dos elos que conduzem as diferentes pessoas na produção de um anúncio são 
resultado de acertos anteriores, que acabam por se tornar costumeiros, um habitus, conforme a visão de Bourdieu (2009 [1980]), determinações que se tornaram parte da maneira padronizada de fazer as coisas. Pode ser verificado na fala, no gestual, na maneira de olhar, na postura e no andar dos sujeitos.

Os condicionamentos associados a uma classe particular de condições de existência produzem habitus, sistemas de disposições duráveis e transponíveis, estruturas estruturadas predispostas a funcionar como estruturas estruturantes, ou seja, como princípios geradores e organizadores de práticas e de representações que podem ser objetivamente adaptadas ao seu objetivo sem supor a intenção consciente de fins e domínio expresso das operações necessárias para alcançá-los, objetivamente "reguladas" e "regulares" sem em nada ser o produto da obediência a algumas regras e, sendo tudo isso, coletivamente orquestradas sem ser o produto da ação organizadora de um maestro. (BOURDIEU, 2009 [1980]: 87)

Bourdieu (2009 [1980]) ressalta ainda o caráter histórico para a formação de um habitus. Em cada grupo social, as relações de dominação são mantidas pela perseverança dos habitus culturalmente construídos. A ordem social é fruto de uma ordem subjetiva erguida em cada agente individual. O habitus funciona como uma materialização da memória coletiva de um grupo, reproduzindo nas gerações seguintes os feitos dos antecessores.

Produto da história, o habitus produz as práticas, individuais e coletivas, portanto, da história, conforme os esquemas engendrados pela história; ele garante a presença ativa das experiências passadas que, depositadas em cada organismo sob forma de esquemas de percepção, de pensamento e ação, tendem, de forma mais segura que todas as regras formais e que todas as normas explicitas, a garantir a conformidade das práticas e sua consistência ao longo do tempo. Passado que sobrevive no atual e que tende a se perpetuar no porvir ao se atualizar nas práticas estruturadas de acordo com seus princípios. (BOURDIEU, 2009 [1980]: 90)

A tendência dos grupos em preservar os seus costumes e rotinas faz com que os atores sociais projetem seu futuro, moldando-o à imagem do passado. Os "conhecimentos adquiridos", as "disposições incorporadas", as convenções planejadas fazem do habitus um operador de categorias de percepção e princípios de classificação no plano prático. O habitus é demarcado pelas condições históricas e socialmente construídas de um campo, portanto, ele garante uma produção balizada pelas condições particulares de cada setor, uma liberdade 
"condicionada" e "condicional" que, tanto pode se desenvolver para a construção de inovação, quanto para a reprodução de um padrão já existente, limitado em sua diversidade (Bourdieu, 2009 [1980]).

O habitus do campo é o efeito automático de vinculação ao campo (Bourdieu, 1983 [1976]). As convenções especificam, tanto as identidades profissionais, quanto os materiais e as decisões subjetivas ou abstratas que serão combinados para a elaboração de um anúncio. O que se passa em um campo jamais é efeito de demarcações externas e sim resultado da expressão simbólica do mesmo (Bourdieu, 1983 [1976]). Portanto, ainda que uma decisão particular modifique o processo de produção de um anúncio específico, por exemplo, as normatizações estabelecidas como modelo de produção da agência e suas funções exclusivas já estão traçadas e fundadas dentro do campo publicitário. As mudanças ocorrem sutil e milimetricamente em cada caso, mas não mudam substancialmente o sistema. $\mathrm{O}$ conjunto de pequenas mudanças em determinada área pode ser adotado como convenção no futuro, mas será encarado muitas vezes como aperfeiçoamento de uma parte e não como um novo sistema.

Becker (1977) acentua ainda que as convenções são responsáveis por regular os direitos e obrigações, não só dentro das organizações, como também entre os agentes produtores e seu público consumidor. Para incentivar as vendas, a publicidade moderna busca criar uma reação emocional através do anúncio. Trindade e Perez (2014) colocam que o sistema publicitário desenvolve "vínculos de sentidos" entre marcas e consumidores. As relações construídas através da narrativa publicitária buscam ganhar sentidos de pertencimento, adequação e troca de afetividades entre produtos e pessoas. Mas para que esse efeito emocional se concretize é preciso que o publicitário desenvolva mecanismos e discursos conectados ao conhecimento e às experiências dos consumidores em cada momento histórico. Significados sociais são acoplados dentro do corpo de convenções existentes para a produção do anúncio, a fim de que as expectativas sejam correspondidas e o trabalho possa ser compreendido. As convenções estabelecerão a coordenação eficiente entre os agentes produtivos, mas a capacidade de compreensão do consumidor está sempre aberta a múltiplas leituras e usos dos produtos, mesmo que as convenções tragam um modelo costumeiro a ser seguido. Por isso, embora padronizadas, as convenções não são totalmente fixas e inalteráveis. Elas trazem um conjunto de regras que os profissionais do 
campo podem se apoiar com facilidade para o desenvolvimento de suas atividades. No entanto, formas de interpretação e negociação travadas no plano do consumo são capazes de modificar as normas gradualmente dentro do sistema e estabelecer elos criativos, novas soluções ou saídas inesperadas.

Richard Sennet (2009) ressalta que a cooperação também pode ser interpretada como uma forma de criatividade. O "artífice", figura pensada pelo autor para descortinar as mudanças do ambiente profissional modernocontemporâneo, incorpora a metamorfose ao longo do processo, é um profissional não engessado pela ideia de representação. Para o autor, a colaboração seria um dos pontos determinantes do mercado de trabalho atual, a ideia de cooperação estaria contaminando os espaços públicos e os empreendimentos humanos e se espalhando de forma viral. A figura do "artífice" simboliza uma espécie de costureiro que deseja fazer um bom trabalho e desenvolve capacidades para isso: "A boa habilidade artesanal implica socialismo." (SENNET, 2009: 321). O "artífice" trabalha com a noção de participação, ações que se desenrolam em cooperação não só com os integrantes de seu ambiente profissional, como também em parceria com diferentes agentes culturais postos em contato através da globalização dos mercados. Sennet (2009) usa os programas de computação de código aberto para exemplificar um produto construído socialmente através da colaboração de atores sociais dispostos em espaços e culturas diferentes, formando uma espécie de "artesanato público". O sistema Linux, diferentemente dos códigos usados pela empresa de tecnologia Microsoft, é um software que se encontra disponível a todos e permite interferências na sua composição. Não só os produtores, mas os próprios consumidores podem modificá-lo, a fim de aperfeiçoá-lo. Cada agente social pode entrar e dar a sua contribuição, como ocorre no caso da Wikipédia ${ }^{40}$. Na maior enciclopédia on-line do planeta, os usuários também são os responsáveis pela construção de conteúdo. Com uma operação construída a tantas mãos é muito difícil não encontrar algum verbete disponível na Wikipédia. O bom artífice encara como oportunidade as

\footnotetext{
${ }^{40}$ Fonte: www.wikipedia.org - Existem vários critérios para publicação de um artigo na Wikipédia. Os dados inseridos podem ser editados e precisam ser baseados em fontes confiáveis e independentes. Colaboradores de diversas áreas do conhecimento são acionados para verificar as informações, aprová-las ou não e aperfeiçoá-las. O modelo concentra uma imensa cadeia de agentes dispersos em espaços e tempos distantes. Assim, um mundo vai sendo formado, a partir de ações coordenadas de atores postos em intercessão, uso de materiais próprios e aprendizado elaborado em etapas sucessivas e dependentes.
} 
dificuldades do trabalho, não se isola ou busca "soluções inflexíveis", tem na colaboração seu espírito aventureiro. Os sistemas se renovam e podem seguir por outros caminhos.

Todavia, as convenções são muito sólidas dentro de um campo. Sendo assim, todo tipo de inovação é incorporada de forma gradativa em cada universo profissional. As convenções podem impor fortes restrições às produções e até mesmo ao pensamento e à criatividade, uma vez que o profissional é ensinado e se acostuma a produzir novidades dentro de um escopo limitado de materiais e possibilidades. A restrição advém da força do sistema implantado, já que as convenções não existem de forma isolada e sim em interdependência. Fazer uma mudança implica em mudar toda ou parte da cadeia de atividades que já trabalha em conjunto (Becker, 1977).

A publicidade trabalha com materiais, equipamentos, treinamentos associados ao tipo de mídia que veiculará o anúncio. Logo as convenções para a produção de um anúncio em jornal impresso são diferentes das convenções usadas para a televisão ou cinema. Cada convenção tem uma estética e uma linguagem próprias. Novas possiblidades e modelos são impostos toda vez que a tecnologia traz recursos e aparatos adicionais que modifiquem os processos produtivos. Os profissionais do campo têm que adaptar-se ou aprender a instrumentalização das novas ferramentas, o que trará consequências paras suas disposições intelectuais e modelos criativos. As restrições são construídas também por sua dependência dos equipamentos e materiais disponíveis em cada momento. Mas essas limitações da prática convencional não são absolutas. Os materiais de outras épocas podem ser retomados ao presente, promovendo uma espécie de releitura, recuperação de estilos, que pode agregar valor ao produto, assim como outras formas de produção podem ser instituídas, desde que se esteja disposto a aumentar custos e esforço de trabalho. As experiências com a mudança das convenções são uma espécie de "desvio" que podem proporcionar satisfação e com isso tornarem-se conhecidas e aceitas, podendo vir a substituir algumas convenções anteriores (Becker, 1977a).

Cada campo do conhecimento desenvolve formas padronizadas de apoio, significados convencionais que sustentam sua estética própria e aceita as restrições exequíveis das ações em cooperação. Quando uma convenção é mudada, transformam-se as formas de percepção daquela estética. Logo, não são apenas os materiais que se alteram, o status da convenção também é ameaçado. 
Consequentemente, os profissionais que se encaixaram como experts em determinados modelos podem perder sua reputação ou prestígio. Embora as convenções tentem preservar seus modelos, o campo está sempre em processo de permanente atualização e construção, influências das frequentes mudanças culturais.

A publicidade, como um setor dentro da esfera social que cria e disponibiliza certos textos e imagens que impactam as identidades culturais, cultiva metamorfoses de suas narrativas constantemente. É preciso que novas ideias sejam elaboradas para que a publicidade continue a anunciar e tentar vender produtos e serviços e, com eles, ideologias. O setor tem a incumbência de atribuir novas categorias de valoração ao mundo de práticas e objetos, essa incessante produção de cultura material que orienta nosso sistema social. Bourdieu (2007 [1979]) reforça que o gosto é um importante marcador valorativo das sociedades moderno-contemporâneas, uma forma de distinção entre os sujeitos no espaço social que se sobrepõe às condições econômicas. O gosto é demonstrado através de estilos de vida e se transforma em base para julgamentos sociais. As preferências estéticas dos indivíduos são, na verdade, distinções, escolhas feitas por oposições às de outras classes sociais. O gosto funciona como um filtro privilegiado das posições de classe, representa um ato de conhecimento, uma operação de decifração e decodificação do mundo estético derivada de um patrimônio cognitivo e uma competência cultural: "Os sujeitos sociais distinguem-se pelas distinções sociais que eles operam entre o belo e o feio, o distinto e o vulgar; por seu intermédio, exprime-se ou traduz-se a posição desses sujeitos nas classificações objetivas.” (BOURDIEU, 2007 [1979]:13). Logo, se os móveis escolhidos para adornar uma casa saem de moda, a decoração é considerada antiquada ou tem-se o ônus de renovar toda a mobília. Se o design dos carros sofre uma modernização pela chegada de novas tecnologias e materiais, cria-se um novo padrão estético para os automóveis e os modelos anteriores são considerados retrógrados. Incentivados pela narrativa publicitária, as novidades em circulação nos mercados rapidamente se tornam cobiçadas por grande parte dos consumidores. O valor é criado pela concordância dos membros ao que é valioso. A publicidade tem a incumbência de atribuir novas significações aos produtos do mundo. 
O anúncio é uma plataforma que vai articular vínculos classificatórios entre os produtos e os consumidores. Tais vínculos precisam ser sempre renovados e reinventados para que o ritual do consumo se perpetue indiscriminadamente (Rocha, 1985). O sistema publicitário e sua produção narrativa organizada pelas agências demarcam processos de transferência de sentidos do mundo social para os produtos e dos produtos para as identidades dos consumidores, fazendo do consumo uma expressão comunicacional básica em nossa cultura.

No próximo capítulo conheceremos aspectos da história da publicidade através da trajetória das principais agências de propaganda instauradas no Brasil. Desde o marco fundador, em 1914, com a agência Eclética, a primeira de muitas que viriam criar um campo de atividades, mudar nosso cenário cultural e consagrar a publicidade como uma instância sociocultural reveladora de valores íntimos da vida coletiva, que a agência passou a ser a instituição que localiza as funções necessárias para que o acontecimento do anúncio se realize socialmente através de uma ação coordenada e convenções estabelecidas. Para Becker (2013), o termo "convenção" indica que os significados partilhados tornam a vida social possível. Assim, foram as convenções publicitárias engendradas por agentes sociais organizados em torno de estruturas produtivas, que fizeram com que a atividade publicitária fosse reconhecida socialmente como um campo profissional. As diversas práticas encadeadas nestas empresas são executadas, com base em composições que provocam uma ação social eficaz e simplificada sem a qual a esfera da produção não se completaria no consumo e os produtos deste mundo não poderiam aparecer. A agência também teve papel privilegiado para a consolidação das identidades culturais em torno da função do publicitário, atribuindo status, valoração financeira, influência social e prestígio ao profissional.

O surgimento das agências foi determinante para traçarmos definições e conceitos sobre o que pode ou não ser considerado publicidade em nosso tempo. Desta forma, entender o processo de profissionalização do campo publicitário através do aparecimento das agências desde o início do século XX é um desafio que pode ajudar na compreensão dos valores sociais construídos por nossa sociedade industrial capitalista, os modos de comportamento ao longo de diferentes épocas e passagens da vida nacional e o desenvolvimento de estreitas relações com a mídia. Propagandas e campanhas renomadas deram sua parte no 
tom da vida pública e incentivaram atitudes e comportamentos traduzidos como estilos de vida, além de reforçarem o consumo como o fenômeno que baliza a experiência cultural dentro de nossa sociedade. Assim como Becker (1977a) afirmou que o mundo da arte expressa a sociedade mais ampla na qual se inscreve, o mundo da publicidade, liberado dos paradoxos e conflitos próprios da complexidade artística, espelha a sociedade moderno-contemporânea que mantém a ideologia do consumo. 


\section{4 - As Agências Pioneiras - identidade e profissionalização}

Dentro do espírito capitalista daquele momento histórico, a fundação da Eclética, primeira agência de propaganda brasileira, em 1914, reunirá as premissas necessárias e se firmará como ponto de partida para a interpretação proposta aqui do legado social e cultural da publicidade brasileira ao longo de cem anos.

Antes do aparecimento das agências eram os próprios veículos de comunicação que vendiam seus espaços diretamente para as empresas, modelo que continua vivo em algumas cidades do interior do Brasil (Barbosa, 2007). O Correio da Manhã, em circulação desde 1901, foi um dos primeiros a veicular mensagens de vendas na imprensa ao ser editado com apenas seis páginas, três delas de avisos comerciais, o que fez com que o jornal conseguisse independência financeira por muitas décadas. Posteriormente, esse modelo se firmou como a seção de classificados (Scherer, 2012). Naquela época, o governo costumava dar valiosos aportes financeiros aos jornais como tentativa de moldar a opinião da imprensa. Campos Salles, presidente entre 1898 e 1902, falava abertamente sobre a compra de opiniões dos jornais como forma de permanência no poder (Scherer, 2012). Em 1905, para aumentar sua receita, o Jornal do Brasil publicou somente classificados na primeira página. A divulgação de notas de vendagem separadas das notícias fez com que o tradicional periódico, lançado em 1891, se tornasse um modelo do jornalismo comercial moderno (Scherer, 2012). Podemos atestar que nesse início do século $\mathrm{XX}$, quando a imprensa iniciava um processo de profissionalização, os jornais viviam das benesses do poder, dadas em forma de "anúncios". Por isso, nos textos noticiosos, era comum uma abundância de elogios aos governos. O Paiz, a partir de 1905, aumenta significativamente o seu número de páginas graças aos comunicados oficiais que passa a veicular diariamente. Atos Oficiais da Prefeitura chegam a ocupar até dez páginas do jornal que atravessa toda a década de 1910 valendo-se das relações próximas com o poder para continuar vivo (Barbosa, 2007).

No setor industrial, as cervejarias Antarctica e Brahma, a Chapelaria Alberto, a Companhia Paulista de Seguros, as lâminas Gillette, a água Caxambu e 
a Caixa Econômica estavam entre os anunciantes que usavam jornais e revistas regularmente para se promover. Muitas vezes, pacotes de espaços fixos eram comprados para obter descontos e criar hábitos de leitura. Àquela altura, os agentes sociais - clientes e jornais, principalmente - já começavam a perceber que a participação de mediadores focados e organizados atuando neste tipo de negociação ajudariam a prosperar vendas. No entanto, foi somente após o fim da Primeira Guerra Mundial que o setor da propaganda ganhou um modelo de negócios composto por cargos, funções específicas, hierarquias, tecnologias, normas, capitais simbólicos, e passou a organizar sua produção em torno de empresas especializadas.

Nos Estados Unidos e em alguns países da Europa, como Inglaterra, França e Alemanha, já existiam agências. Estes grandes centros contavam com companhias voltadas para a compra e venda de espaços nos meios de comunicação desde meados do século XIX. A primeira agência norte-americana foi criada na Filadélfia. Seu fundador, Volney Palmer, foi possivelmente o primeiro a usar a expressão "Advertising Agency" para designar esse tipo de negócio (Hower, 1978). No início de 1842, a empresa já estava estabelecida com clientes na Pensilvânia, em Maryland e expandia as transações também para os estados de New Jersey, Missouri, Kentucky, Tennessee e Alabama. O empreendimento inaugurou bases para um mercado vigoroso ao instituir a cobrança da taxa de $25 \%$ de comissão dos jornais para vender espaço publicitário, o que era feito anteriormente por corretores de propaganda (Pincas; Loiseau, 2008).

Vinte e sete anos depois, em 1869, temos o surgimento da agência $N . W$. Ayer \& Son, também na Filadélfia. A cidade mais populosa da Pensilvânia é um dos lugares mais importantes da história americana. A região foi um dos principais focos da Guerra de Independência dos Estados Unidos durante a década de 1770, com atuação incisiva da organização "Filhos da Liberdade". Em seu território foi oficializada a Declaração de Independência dos Estados Unidos e a Constituição. No início do século XIX, apresentou crescimento industrial, com setores bem desenvolvidos de têxteis, vestuário, metalurgia, fabricação de papel e material ferroviário, naval e transformação de alimentos. A cidade também se destacou como importante centro financeiro. O espírito de patriotismo é muito preservado na cultura local, a ponto de seus habitantes se emocionarem com o 
hino nacional e espalharem bandeiras por todos os lados (Driver, 2006). A mítica em torno da conquista da liberdade por uma jovem nação junto ao incremento industrial talvez possa explicar a preponderância da Filadélfia no negócio da publicidade.

A N.W. Ayer \& Son foi a primeira agência a assumir a responsabilidade pelos conteúdos das propagandas, se tornando pioneira em oferecer todos os serviços de publicidade ao cliente. A empresa introduziu o contrato aberto, o que mudaria o mercado da publicidade em definitivo. Esta prática comercial faria com que as agências negociassem com as publicações, a fim de garantir os preços mais baixos possíveis aos clientes. Comissões foram posteriormente adicionadas e variavam em torno de 8,5 a 15\%. A partir de 1909, o "contrato aberto" ficou conhecido como "O.C. $+15 \%$ " de comissão da agência. Este modelo se tornou mais tarde o padrão das transações publicitárias. A empresa da família Ayer é considerada a agência mais antiga dos Estados Unidos e criou slogans memoráveis para empresas como $A T \& T$, De Beers e até para o exército americano (Hower, 1978). O ocaso se deu nos anos 1960, e depois de uma série de fusões, a agência fechou as portas em 2002, depois de 133 anos de atividades. Sua influência foi extremamente relevante no mundo da publicidade, sobretudo com a criação de uma publicação própria, o “Ayer \& Son's Manual for Advertisers”, com listagem de jornais, informações, preços e circulação dos periódicos. Em 1876, lançaram outra publicação de destaque, o “The Advertiser's Guide”, com novidades do mundo dos negócios, histórias engraçadas e artigos sobre publicidade (Pincas; Loiseau, 2008).

A partir da Ayer surgem novas agências. Em 1878, é inaugurada a $J$. $W$. Thompson após a compra da agência Carlton \& Smith, em Nova Iorque. A primeira agência da cidade, a John Hooper \& Co, havia sido estabelecida alguns anos antes, no início da década de 1870 . No fim do século XIX, com a aceleração da Revolução Industrial e o desenvolvimento de economias mais produtivas, a $J W T$, sigla pela qual a empresa ficou conhecida, soube aproveitar oportunidades e ajudar os proprietários de lojas movimentadas a anunciar seus bens de consumo. No período que vai do fim dos anos 1870 até a década de 1910 houve uma rápida industrialização nas cidades americanas, com inovações científicas, tecnológicas e o crescimento de grandes companhias. Às vésperas do novo século, a mais antiga agência de publicidade em funcionamento no mundo decide contratar escritores e 
artistas para incrementar a propaganda destas empresas em franca ascensão e ajudar a vender mais espaços nos jornais. Este foi um momento marcante na história da publicidade, uma vez que começa a percepção de que o negócio deveria incorporar ideias criativas para impulsionar vendas. Nasce um esboço do Departamento de Criação e, com ele, a elaboração de anúncios mais complexos ${ }^{41}$.

Este período que marca o aparecimento das primeiras agências americanas foi classificado por Karl Polanyi (2012 [1944]) como "cem anos de paz". O importante estudo "A grande transformação" (2012 [1944]) define o ciclo localizado entre 1815 e 1914 como um tempo de paz. O crescimento econômico e o bom relacionamento entre os países traziam a aparência de uma relativa prosperidade, com um cenário favorável aos negócios, expansão das capacidades industriais das principais potências e aceleração da circulação de mercadorias e trocas comerciais.

\begin{abstract}
O mercado se interessava em demasia pela paz e praticava uma política distinta da executada em momentos anteriores da história, quando a organização comercial era baseada em guerras, conflitos, armadilhas, lutas corporais, e tinha como personagens figuras como exploradores, conquistadores e comerciantes de escravos. Durante os "cem anos de paz", os grandes comerciantes e industriais perceberam que esse clima era bom para os negócios, pois estimulava transações internacionais, contribuía para a expansão dos mercados e fazia com que as pessoas ocupassem o espaço público e gastassem rapidamente o dinheiro que ganhavam. (ROCHA; FRID; CORBO, 2016)
\end{abstract}

Nesse contexto, o bom desempenho corporativo faz com que a JWT alargue sua área de atuação em direção a outros países. A abertura da filial de Portugal, por volta de 1926, contou com a colaboração de Fernando Pessoa. Pessoa desenvolveu uma longa relação com a publicidade desde 1907, quando começa a trabalhar na R.G. Dun \& Company, empresa americana de informações comerciais. É do escritor a célebre frase publicitária “primeiro estranha-se, depois entranha-se", criada para a campanha da Coca-Cola, em 1928, o que fez as vendas dispararem (Almeida, 1954). Em 1927, a JWT abre os primeiros escritórios no Egito e na África do Sul.

\footnotetext{
${ }^{41}$ Fonte: www.jwt.com
} 


\section{1- A agência Eclética e a inauguração da era da propaganda no país}

Alicerçada nos modelos de negócios das agências de destaque norteamericanas, com o intuito de atrair maior público consumidor, a atividade publicitária foi rapidamente se expandindo e se aprimorando em direção a este padrão que explorava a criatividade na veiculação das mensagens comunicativas. Profissionais refinaram suas técnicas, e critérios rigorosos de qualidade foram elaborados nas décadas seguintes em várias partes do mundo.

A Eclética, propriedade da empresa Castaldi \& Bennaton, compõe as primeiras bases para que este aprimoramento do setor chegue ao Brasil. Criada em maio de 1914, em São Paulo, a mais antiga agência de propaganda nacional reproduziu o modelo conhecido nos Estados Unidos. Instalada na Rua João Bricola, esquina com a 15 de Novembro, a empresa instaurava uma modalidade de negócios que até então era praticada como uma 'ação entre amigos'. O empreendimento foi responsável por estruturar o agenciamento de anúncios para os jornais da época, principalmente para O Estado de S. Paulo, por iniciativa do jornalista João Castaldi, proprietário do jornal A Capital, em parceria com o empreendedor Jocelyn Bennaton. Os principais diretores da Eclética foram Julio Cosi, em São Paulo, e Eugenio Leuenrotth, no Rio de Janeiro, onde a agência se estabeleceu a partir de 1918 (Rabelo, 1956).

A Eclética também participou do início do movimento associativo da propaganda brasileira. Em 1932, a Associação Paulista de Imprensa é fundada sob a liderança de Julio Cosi. Com o movimento constitucionalista daquele ano, a corporação é prejudicada e só consegue se reorganizar no ano seguinte, com o Congresso Jornalístico. Em seguida, são criados a Associação Paulista de Propaganda (atual Associação dos Profissionais de Propaganda), o Sindicato das Agências de Publicidade Comercial do Estado de São Paulo, a Federação Paulista de Rádio e a Associação das Emissoras de São Paulo. Cosi tem sua trajetória marcada por inaugurações de rádios, como a Rádio Panamericana S/A, passagens em jornais e participação atuante na organização e certificação da profissão de publicitário. Em 1937, ajuda a instituir a Associação Brasileira de Propaganda (ABP) (Reis, 1990). 
Nos primeiros anos, a Eclética concentrou sua atuação comercial na negociação de espaços midiáticos, mas logo aperfeiçoou suas técnicas de comunicação e vendas atraindo as contas mais importantes do mercado, entre elas a da Ford Motor Co e a da Texaco (Abreu; Paula, 2007). Os jornais eram bastante pobres em publicidade e a imprensa dependia de vínculos políticos. $\mathrm{Na}$ comunicação impressa reinava o padrão opinativo, com os jornais servindo de plataformas para a veiculação de extensos textos com apreciações políticas e reclamações sociais. A construção da notícia objetiva isenta de opinião é colocada em prática um pouco mais tarde, e marca o jornalismo a partir da década de $1920^{42}$ (Barbosa, 2007).

O processo de publicação de anúncios funcionava de maneira informal. Em geral, um comerciante concordava em anunciar em jornais quando considerava o corretor um bom sujeito ou porque ele era amigo de um político influente. A propaganda ainda era muito rudimentar, feita de forma improvisada e sem muitos recursos. $\mathrm{O}$ corretor era visto como um sujeito inconveniente que batia à porta das casas de comércio para suplicar anúncios. Alguns estabelecimentos, inclusive, colocavam o seguinte aviso à porta: "Esta casa não dá esmolas e não atende a gente de publicidade.” (RABELO, 1956: 92).

Com a conquista da conta da Ford, em 1925, a Eclética conseguiu, aos poucos, mudar essa mentalidade. A contratação de meia página da edição de domingo do jornal $O$ Estado de S. Paulo fez com que novas estratégias fossem traçadas para a publicidade da fabricante de carros. Houve a necessidade de anunciar também em jornais do interior, uma vez que a Ford tinha concessionárias espalhadas pelo país. O receio dos proprietários desses jornais em relação à "gente de publicidade" dificultou o contato e travou uma verdadeira batalha dos profissionais para conseguir a entrada da agência no interior. $\mathrm{O}$ negócio passou a girar em torno das capacidades de persuasão dos publicitários, que viajavam pelo Brasil com o objetivo de convencer os donos de jornais de que a publicidade era uma estratégia promissora e que podia contribuir com as vendas.

${ }^{42}$ Contudo, é importante ressaltar que o jornalismo brasileiro só adotou definitivamente uma linguagem informativa e especializada, com a separação entre fatos e opiniões, com o fim da Segunda Guerra Mundial, através da adoção do lead. Esta técnica, vinda do jornalismo norteamericano, consiste em responder, logo no primeiro parágrafo da notícia, às perguntas básicas: Quem? Quando? O que? Como? Onde? Por que? No Brasil, foi adotada pela primeira vez no Diário Carioca, em 1951. A influência cultural francesa, que permitia o uso de adjetivos, textos prolixos, linguagens romantizadas, próximas da literatura, foram deixados de lado em prol de uma objetividade crescente na construção das notícias (Sodré, 1999). 
Para vencer as dificuldades, uma iniciativa foi importante. A Ford instituiu a colaboração e o pagamento aos agentes, com a ajuda da verba de divulgação, contribuindo com trinta mil réis por carro vendido, o que corresponde hoje a aproximadamente mil e duzentos reais. Cada carro custava cerca de quatro milhões de réis, ou seja, cerca de 160 mil reais ${ }^{43}$ (Rabello, 1956).

Depois da primeira conta estrangeira conquistada por uma agência nacional, o mercado sente a necessidade de tornar nossa imprensa mais conhecida no exterior, a fim de atrair novos parceiros. Em 1926, Julio Cosi organiza, em nome da Eclética, a $1^{\text {a }}$ Exposição da Imprensa Brasileira, com exemplares de nossos jornais e revistas, além de gráficos e números que atestavam o crescimento da comunicação brasileira. O diretor considerava pequena diferença de qualidade entre os anúncios americanos e os brasileiros, uma vez que utilizávamos os referenciais estrangeiros como inspiração para nossas campanhas (Rabelo, 1956).

Além da Ford e da Texaco, a Eclética atendeu as contas mais importantes das primeiras décadas do século XX, como Shering, Sabonetes Eucalol, Biscoitos Aymoré, Produtos Miami de Toucador, Chocolate Lacta, Guaraná Espumante, Indústria Matarazzo e Westinghouse. Para a Texaco, elaborou mapas das principais estradas brasileiras, com a sinalização de seus postos de gasolina (Reis, 1990). Com a Eclética, o mercado - comerciantes, empresários, farmacêuticos, leiloeiros - começa a descobrir o poder da publicidade comercial. A conquista de importantes clientes foi consequência, não só do talento criativo de seus profissionais, como também da estrutura interna bem dividida entre os departamentos de Arte, Texto e Criação, atestando a profissionalização da empresa. Esta organização inicial foi posteriormente experimentada por outras agências, o que ampliou o campo no país, como atesta Julio Cosi em depoimento a Genival Rabelo (1956):

A Eclética foi sempre uma espécie de célula-mater na propaganda. Dela saíram elementos, que depois de experimentados, fundaram novas agências, ampliando o campo da publicidade. Por ela passaram nomes que hoje são expoentes da classe, do que a Eclética se envaidece. (RABELO, 1956: 85)

\footnotetext{
${ }^{43}$ Valores convertidos através do aplicativo "Conversor de valores", do acervo digital do jornal $O$ Estado de S. Paulo. http://acervo.estadao.com.br
} 
Mesmo assim, as funções não eram tão bem definidas em cada setor. A agência trabalhava como uma grande orientadora de publicidade para o cliente. Os donos da empresa contribuíam em várias facetas do negócio, estabelecendo uma relação bem próxima com os clientes, quase familiar. Assim foi com a fundação da grande loja de roupas A Capital, de Milton e Nilton Carvalho. A Eclética ajudou com a procura do local, a pesquisa do melhor ponto de venda, a instalação da loja (Rabelo, 1956).

Os primeiros trabalhos de pesquisa publicitária no Brasil também foram instituídos pela Eclética, quando ela cria o chamado Departamento Estrangeiro, que começou a promover estudos de mercado com consumidores e anunciantes. O modelo foi o precursor das análises de opinião pública e estudos de mídia feitas a partir de 1942 pelo Instituto Brasileiro de Opinião Pública e Estatística, o Ibope, uma das maiores empresas de pesquisa de mercado da América Latina, que atua em 15 países. Hoje o Ibope oferece um variado conjunto de dados e estudos sobre mídia, consumo, mercado, comportamento, opinião pública e intenções de voto. O nome da instituição é usado coloquialmente pela população como sinônimo de audiência e prestígio em relação à programação midiática.

As pesquisas foram o principal caminho adotado para o desenvolvimento de um anúncio na Eclética. Nesse sentido, buscou-se o estabelecimento de ações coordenadas e sequenciais para a elaboração de uma peça publicitária baseada no levantamento de dados. Com o tempo e a prática, as atividades seriam aprendidas e realizadas com eficiência pelos diferentes profissionais dotados de seus papéis específicos, tornando-se um modelo de gestão rotineiro (Becker, 1977). Ao receber uma conta, a primeira providência a ser tomada deveria ser a investigação completa das informações sobre o produto, tais como fabricação, principais características, finalidade, preço, distribuição, vantagens em relação aos concorrentes, poder aquisitivo dos clientes em potencial e particularidades do mercado. Em seguida, era feito o estudo para a escolha do veículo mais adequado de comunicação para os clientes que desejavam conquistar, levando em consideração a influência da mídia, o alcance, o preço e o local. A partir desses levantamentos anteriores, a campanha começava a ser planejada. $\mathrm{O}$ resultado bem sucedido contava com a contribuição de um Departamento Gráfico equipado com modernas máquinas e profissionais especializados, além do trabalho dos ilustradores (Abreu; Paula, 2007). Ou seja, cada ator social, dotado de sua 
identidade profissional, colocou em prática uma competência característica, elaborada pelas convenções de seu setor, para que assim o anúncio pudesse ser construído e viesse a aparecer socialmente. O sucesso do sistema e a fabricação de um produto são decorrentes da articulação das identidades individuais projetadas dentro de uma agência, suas ligações cooperativas e circuitos integrados (Becker, 1977).

Um marco para a Eclética foi a organização dos "Anúncios Classificados" do jornal $O$ Estado de S. Paulo, juntamente com uma campanha de assinaturas. A agência conseguiu a exclusividade de publicação da seção. Após a consolidação, o espaço passou a ser gerenciado pela administração do jornal, conforme combinado. O aparecimento dessa subdivisão foi muito celebrado pela indústria e comércio e até hoje é um espaço forte no cenário da imprensa brasileira. $\mathrm{O}$ modelo já era usual nos jornais internacionais.

No início, os anunciantes escondiam as informações sobre seus negócios, o que dificultava as pesquisas. Para o estudo das plataformas de veiculação, a Eclética sentiu a necessidade de levantar dados informativos e estatísticos sobre a imprensa em geral. Por isso, começa a editar o Jornal dos Jornais, com tabelas de preços, dimensões de colunas e páginas do Brasil e exterior, preço das assinaturas, tiragens (Rabelo, 1956). O resultado deu tão certo que pouco tempo depois é lançado o "Anuário da Imprensa Brasileira", coordenado por Leuenroth. O anuário teve sua publicação interrompida pelo DIP, o Departamento de Imprensa e Propaganda do governo Vargas, criado em 1939 para controlar, orientar e coordenar a propaganda oficial e todas as ações de comunicação e cultura produzidas no país. O órgão foi inspirado em modelos de outras ditaduras mundiais da década de 1930, e tinha como objetivo principal trabalhar em torno da promoção e cultivo da figura de Vargas. Pouco tempo depois, o próprio DIP cria uma versão do "Anuário da Imprensa Brasileira", como publicação oficial. Outra edição da Eclética, a revista "Propaganda", que destacava os direitos da classe e as vantagens do aumento da publicidade para o mundo comercial, também foi tirada de circulação pelo DIP (Rabelo, 1956).

Entre bons e maus momentos, grandes contas e outras nem tanto, nossa primeira agência destaca-se por ter sido pioneira na organização da propaganda como um negócio no Brasil. Seu maior legado foi ter proporcionado o início de uma mudança de percepção em todos os envolvidos no processo publicitário: o 
anunciante, o veículo de comunicação, o público consumidor e até o funcionário da agência. Discípula dos modelos internacionais, soube adequar as lições a um jeito brasileiro de fazer propaganda, tentando sempre captar o elemento mais penoso do processo, a emoção de seus clientes e consumidores.

Assim, a constituição de uma empresa que pudesse aglutinar os elementos ainda dispersos da prática publicitária contribui para formar as bases do segmento e construir uma imagem de profissionalismo e aparelhamento necessários ao reconhecimento jurídico e social do setor. O padrão de empreendimento adotado desbravou e começou a dar forma a um campo inexistente no país. O interacionismo simbólico pode ser observado através das normas de comportamento adotadas, da disposição das ações, das etapas a ser cumpridas e dos elos colaborativos entre as diferentes partes. Tais procedimentos montaram uma espécie de cartilha da fabricação de anúncios, que serve não apenas para a materialização da produção, como também para a construção das identidades profissionais. A representação do papel de cada ator social se dá, inclusive, fora da esfera da agência e se compõe como identidade cultural (Becker, 1977, 1977a). A ampliação do mercado da propaganda teve grande importância na vida econômica do país a partir de então. Um desafio subsequente seria o de educar o público consumidor a interpretar as mensagens dos anúncios, fazê-lo dispor de conhecimento para entender rapidamente as linguagens empregadas para vender as funcionalidades e as vantagens de uso de um bem ou serviço.

Com esses princípios de modelagem e de organização empresarial do campo publicitário, nascem as ações nacionais programadas. O laboratório Biotônico Fontoura foi um dos primeiros a apostar em técnicas sofisticadas com peças temáticas, veiculadas com certa frequência e volume planejados, apropriação de símbolos de grande aceitação do público. O escritor Monteiro Lobato havia criado o Jeca Tatu, um caipira que ensinava noções de higiene e saneamento às crianças, e expressava os costumes regionais brasileiros. $\mathrm{O}$ personagem da literatura infanto-juvenil foi cedido nos anos 1920 para seu amigo Candido Fontoura aprimorar a promoção do tônico, o que alavancou as vendas e gerou uma simpatia ao produto. O processo ficou conhecido como "linguagem associativa", muito usado posteriormente pelas agências (Ramos; Marcondes, 1995). Com a fama do medicamento, também foi criado o "Almanaque Fontoura", um livreto distribuído gratuitamente em farmácias, contendo histórias, jogos, 
campanhas de conscientização e publicidade. O folheto teve vida longa, e em 1982 chegou à marca de 100 milhões de exemplares distribuídos, sendo considerada a peça publicitária de maior sucesso no Brasil ${ }^{44}$.

Outra empresa que apostou em novas técnicas foi a Bayer, que desde 1896, antes mesmo das agências, já anunciava os benefícios da "Aspirina" no país. Campanhas com temas específicos e peças distintas deram destaque ao analgésico. Em 1922, a Bayer passa a contratar a agência Bastos Tigre, que cria um dos slogans mais conhecidos da história da propaganda: "Se é Bayer, é bom". A mensagem atravessou gerações e até hoje é adotada no Brasil e em países de língua espanhola: "Si es Bayer, es bueno" 45 . Os anúncios e arrojadas campanhas publicitárias da Bastos Tigre destacaram-se pelo tratamento humorístico e arrojado, contribuindo para o sucesso do mercado brasileiro (Ramos; Marcondes, 1995).

Marcas como Colgate, Nestlé e Valda estavam entre os principais anunciantes daquele início de século, com crescente presença em jornais e revistas. Além da Eclética, ao fim da Primeira Guerra Mundial, o Brasil contava com outras quatro agências de propaganda em São Paulo: a Francisco Pettinati, a Edanée, a Valentim Haris e a Pedro Didier e Antônio Vaudagnoti (Ramos; Marcondes, 1995), todas referenciadas pelos moldes norte-americanos. Com uma defasagem de cinquenta anos em relação aos Estados Unidos, tivemos a vantagem de começar importando modelos de negócios já testados e técnicas das mais modernas que havia no período. No entanto, não se notam grandes mudanças nos anúncios de jornais do Rio de Janeiro e São Paulo nos anos da guerra. Com o conflito, o clima de euforia da Belle Époque havia sido deixado de lado e o governo buscava estimular um sentimento de pertencimento nacional (Scherer, 2012).

As imagens com sons e movimentos foram importantes aliados na política de propagação do espírito ufanista do governo. No começo da década de 1910, a experiência cinematográfica foi incrementada com o aparecimento dos cinejornais, curta metragens de caráter informativo exibidos antes dos filmes, como uma espécie de trailler. Marcos Luporini (2007) afirma que já nos “(...) primórdios do cinejornalismo houve a percepção que, diferentemente da imprensa

\footnotetext{
${ }^{44} \mathrm{http}: / /$ lobato.globo.com/misc_jeca.asp

${ }^{45}$ Fonte: www.bayer.com.br
} 
escrita e falada, o jornalismo audiovisual poderia destacar-se pela animação, presença e contundência." (LUPORINI, 2007: 02). Com isso, equipes de jornalismo foram deslocadas para a cobertura de grandes eventos. Na tela gigante, os espectadores conferiam as principais notícias da cidade e anúncios publicitários, principalmente os do poder público, em filmes de até dez minutos. Entre os assuntos da semana, propagandas governamentais, inauguração de obras, anúncios de moda e muitas informações do universo do futebol. As notícias eram narradas sobre imagens dos acontecimentos filmadas em câmeras ainda muito rudimentares, geralmente sem o áudio ambiente. O Pathé-Journal foi o primeiro cinejornal, criado na França, em 1908. Aqui no Brasil, o formato chega em 1912 e ganha popularidade. Os cineastas, chamados pejorativamente de cavadores pelos jornalistas, estavam mais interessados no lucro do que nos requintes estilísticos de seus curtas-metragens, já que esta indústria atraía muito dinheiro, sobretudo verbas de anúncios (Luporini, 2007).

Para o campo da publicidade, os cinejornais significam uma nova plataforma de distribuição. Cada novo dispositivo de comunicação ou tecnologia possui uma estética e uma linguagem próprias, o que ocasiona uma remodelação das ações do campo. Os processos produtivos são modificados e outras convenções estabelecidas para lidar com as novas funções, aparatos, ferramentas e recursos. Nesse sentido, os profissionais encontram-se diante do desafio de promover adaptações de suas condutas e papéis, o que traz consequências para suas disposições subjetivas e culturais. Muitas vezes, é preciso deixar para trás as antigas convenções e aprender a lidar com os novos equipamentos e materiais. O “desvio" da convenção, como assinala Becker (1977a), pode provocar medos, ansiedades. Profissionais que não se adaptarem podem ter seu capital simbólico ameaçado e perder seu prestígio em um meio, assim como outros se adequam com facilidade e podem ter ganhos ou mesmo mudar de posição hierárquica (Bourdieu, 1983 [1976]). A alteração de uma convenção também transforma as formas de percepção daquela estética, além da ampliar as possibilidades de atuação de um campo e emprego de profissionais (Becker, 1977).

Muitos cinejornais eram encomendados por governantes ou empresários bem-sucedidos que queriam propagandear seus êxitos em forma de notícia. Durante a Era Vargas, o cinejornal oficial da Agência Nacional - Cinejornal Brasileiro - foi exibido obrigatoriamente nos cinemas e teve extrema importância 
para a popularização e culto à imagem do presidente. Em geral, os temas giravam em torno das mensagens do governo, que fazia questão de divulgar os eventos políticos, inaugurações, paradas militares e a glorificação da imagem do Brasil, exaltando as belezas naturais. O formato perdurou até a década de 1980, quando o aumento da produção televisiva provocou o ocaso dos cinejornais.

Ainda nas duas primeiras décadas do século XX, o modelo profissional de agência no Brasil aparece em competição com os jornalistas, que também realizavam a corretagem de anúncios, uma espécie de comissão informal dada pelos jornais para quem trouxesse publicidade até eles. $\mathrm{O}$ jornalismo daquele início de século estava muito ligado à ideia de vocação, era visto como um verdadeiro sacerdócio, sendo separado da intenção capitalista de maximizar os lucros. Os editores dos periódicos, em geral, não tentavam usar a publicidade para ganhar dinheiro. Até porque, devido ao pequeno tamanho do nosso comércio, não havia urgência em anunciar (Barbosa, 2007).

A Eclética encerrou suas atividades no início da década de 1960. Cronologicamente, há registros de outras agências mais antigas. A primeira, ainda sem o rigor de uma organização empresarial, teria sido a Empresa de Publicidade e Comércio, instalada em São Paulo, em 1891, com direção de Honório da Fonseca, antigo redator do jornal Correio Paulistano (Reis, 1990). No livro Jornal, história e técnica, o jornalista e pesquisador Juarez Bahia ratifica a primazia da Eclética:

No Brasil, antes de 1913, não se conhece organização especializada em distribuir anúncios para os jornais. A primeira firma que pode merecer a classificação de agência de propaganda instala-se em São Paulo entre 1913 e 1914. É a Castaldi \& Bennaton, proprietária de A Eclética. (BAHIA, 1990: 282)

Para Martensen (1990), a Eclética representou um “(...) verdadeiro marco do empresariado publicitário brasileiro.” (Martensen, 1990: 32). Em depoimento, Julio Cosi também ressalta a estrutura mercadológica da agência, sublinhando suas conquistas com uma espécie de medição de audiência particular:

71 produtos em 24 horas, 94 produtos em 24 jornais, 97 produtos em 26 jornais, 95 produtos em 30 jornais, eram alguns dos títulos em tabelas que organizamos mostrando, produto por produto, a centimetragem utilizada em cada jornal. (REIS, 1990: 303) 
Àquela altura, o ofício de uma agência de propaganda ultrapassava e muito a atividade da corretagem de anúncios. A agência especializou-se em localizar mercados, estudar o poder aquisitivo de seus clientes e dos compradores em potencial, pesquisar e conhecer o consumidor do ponto de vista emocional, psicológico, computar estatísticas de vendas, analisar canais de distribuição, pensar em estratégias para otimizar a utilização dos meios, reunir habilidades artísticas de seus funcionários para a produção de anúncios e uma série de outras ações para a realização do que viríamos a chamar de "publicidade moderna". Os negócios nesse setor no Brasil se tornaram mais complexos e sofisticados, com a integração de uma série de elementos, funções e regras em torno da agência. A produção de anúncios em uma empresa de publicidade, como vimos, envolve a integração de múltiplos agentes, sujeitos que "fazem coisas juntas" e interagem entre si, através de suas convenções criadas e compartilhadas e dos elos travados com o mundo exterior. O "drama da ação" é produzido com a capacidade transformadora dos agentes sociais (Becker, 1977, 1986). Portanto, o aparecimento de uma narrativa publicitária no campo social está intimamente relacionado a seus atores e no diálogo destes com seu tempo. Os rituais de cada campo e as estratégias de troca são preciosos elementos para a construção do campo social como um todo, como assinala Bourdieu (1983 [1976]). O anúncio é parte expressiva da dinâmica social, e deve ser pensado levando-se em conta o contexto, a experiência e a trajetória de seus idealizadores. A construção de identidades profissionais em torno das empresas de publicidade transforma as condutas no segmento, bem como insere uma nova problemática interacional na cultura com sujeitos imbuídos de outros papéis sociais (Becker, 1977).

\section{2 - Efeitos da Primeira Guerra Mundial}

Com o fim da Primeira Guerra em 1918, a paisagem começa a se modificar. A expansão norte-americana bate às nossas portas e transforma o mercado brasileiro. A economia do país volta a ganhar fôlego com a grande demanda internacional por diversos gêneros alimentícios e matérias-primas, o que provoca mudanças na estrutura basicamente agrícola. Vivemos um surto de 
atividade industrial inédito em nossa história, incrementado pela mão de obra imigrante. Neste momento, chega ao país um grande fluxo de europeus que fugia da fome e dos estragos causados pelo conflito. A nova fase de expansão do café que necessitava de trabalhadores para as lavouras e o crescimento dos centros industriais atraíram grandes contingentes populacionais a partir da década de 1920. Italianos, espanhóis, portugueses, alemães, austríacos, russos, japoneses, sírios e libaneses foram responsáveis pelo aumento da produção cafeeira, e também estiverem presentes nos processos de urbanização das grandes cidades. Estima-se que cerca de um milhão e meio de imigrantes chegaram ao país entre 1910 e 1920. Mais da metade dos estabelecimentos comerciais de São Paulo era gerida por empresários vindos de fora ${ }^{46}$. O número de fábricas cresce significativamente, dobrando a quantidade de funcionários. Com a diminuição de produtos importados em circulação, o mercado interno se fortalece e modifica a face social e econômica do país. O comércio nas grandes cidades aumenta de volume e já esboça os primeiros indícios da voraz competição mercantil que viria a se instalar nas décadas seguintes (Prado Junior, 1977).

A industrialização do país foi incrementada com o auxílio da publicidade. Precisávamos de um consumo em massa que desse vazão ao aumento da produção industrial. Para garantir a compra imediata das mercadorias que acabavam de ocupar as prateleiras das lojas, nada melhor do que criar simpatia do público para o novo produto, através de mensagens de persuasão, que impactam psicologicamente o cliente e obrigam as lojas a comprar novos estoques.

Concomitantemente ao surgimento das primeiras agências de propaganda, que estavam profissionalizando as técnicas para a comunicação na venda de bens e serviços, também apareciam estações de rádio, maior número de jornais e revistas, empresas de placas e estradas (Rabelo, 1956). A combinação das estratégias para alcançar cada uma dessas plataformas com linguagens específicas proporcionou a consolidação da publicidade em substituição à corretagem de anúncios. Afinal, o texto do rádio, o anúncio do jornal, o cartaz da estrada pediam abordagens mais elaboradas e diferenciadas. Como dissemos, a cada nova tecnologia de comunicação, outras habilidades, linguagens e disposições intelectuais são exigidas dos profissionais. Convenções sofrem desvios e atores

\footnotetext{
${ }^{46}$ Fonte: CPDOC - FGV. Disponível em: https://cpdoc.fgv.br/producao/dossies/AEraVargas1/anos20/CafeEIndustria/Imigracao
} 
sociais se veem diante da necessidade de adaptação, a fim de preservar suas posições hierárquicas no campo (Becker, 1977).

A partir do incremento do mercado editorial e das transformações sociais vivenciadas naquele tempo, efetiva-se a ideia de que absolutamente tudo poderia ser posto à venda. Quanto mais a sociedade modificava, mais a vida urbana se tornava dependente de artefatos materiais e serviços - produtos que em outros tempos eram inimagináveis. Começamos a esboçar o nascimento do que mais tarde viria a ser chamado de sociedade de consumo. Os processos de industrialização e a ascensão de veículos de comunicação invadem os estilos de vida desta coletividade urbana em expansão, que ancora no fenômeno do consumo o destino de boa parte de suas interações materiais e subjetivas. Aproveitando-se do espaço ocupado pelo consumo na vida moderna, a narrativa publicitária cria mensagens que traduzem a cultura e trazem necessidades que vão muito além dos artefatos materiais e são, sobretudo, simbólicas (Rocha, 1985). Os anúncios que, até os anos 1920, funcionavam como espaços de veiculação de informações estáticas, ainda que elogiosas, e pouco mais que descritivas do produto, começam a perceber uma vocação para ir muito além. A atividade publicitária é a difusão pública de ideias, associadas ou não ao valor de uso de um produto, que garante algo mais do que a mera satisfação propiciada por sua funcionalidade. Para Jean Baudrillard (2010 [1970]) as noções de verdade e mentira perdem o sentido no reino da publicidade. $\mathrm{O}$ autor enfatiza que a publicidade moderna nasce quando um anúncio deixa de ser "anúncio espontâneo" e se torna uma "notícia fabricada" (BAUDRILLARD, 2010 [1970]: 167).

As necessidades de propaganda do mercado nacional rapidamente alastraram o negócio das agências. A pausa do setor ocasionada pela Primeira Guerra foi suspensa com o surgimento da segunda agência brasileira: Agência Moderna de Publicações Ltda., inaugurada em 1919 por Fidélis Saldanha Botelho, Edgar Saldanha Botelho, Edgar Saldanha Menezes e Aldo Roccato (Reis, 1990). A empresa passou a divulgar seus préstimos com cartazes ilustrados nas páginas de jornais, como o veiculado pelo O Estado de S. Paulo, que trazia o seguinte slogan: "Uma boa ideia faz fortuna. Sugestões de efeito seguro e absolutamente originais para anúncios ilustrados, procurem a Agência Moderna 
de Publicações. ${ }^{47}$ " Foi a primeira agência a anunciar a si mesma e proclamar seu tipo de produto. Observa-se a necessidade de expor o negócio da publicidade à população em geral, tornar o mercado de anúncios cada vez mais conhecido e causar entendimento e familiaridade à principal mercadoria da agências, que é a própria publicidade.

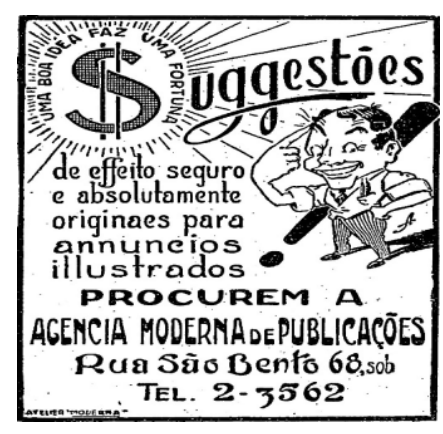

Mais tarde, em 1969, sob a direção dos quatro filhos de Fidélis, a empresa se transformou em Agência Moderna de Publicidade Ltda. No fim da década de 1970, três irmãos se desligaram para fundar a Botelho \& Associados $e$ Propaganda (Reis, 1990).

Em seguida, temos a fundação da Agência de Publicidade Pettinati Ltda., na capital paulista, em janeiro de 1920. A empresa familiar do comendador Francisco Pettinati, um dos organizadores da Semana de Arte Moderna de 1922, se tornou um lucrativo negócio. A Pettinati foi a primeira agência a levar publicidade para todo o território nacional. Encarregou-se, durante 20 anos, das contas das maiores empresas cinematográficas norte-americanas, entre elas a Paramount, a Metro Goldwin-Mayer, a Fox, a United Artists, a Universal e a RKO (Rabelo, 1956).

Ainda em 1922, a agência contrata Heitor Villa-Lobos para compor um jingle para o Guaraná Antarctica. O maestro usou os versos do poeta e jurista Guilherme de Almeida para elaborar a música. As importantes empresas de bebida Seagers e Cinzano também fizeram parte de sua cartela de clientes a partir de 1925. A propaganda do gim Seagers chegou a ser veiculada na Inglaterra, em 1946 (Abreu; Paula, 2007). O cartaz publicado nas páginas do O Estado de S.

\footnotetext{
${ }^{47}$ Fonte: www.propagandashistoricas.com.br
} 
Paulo em 03 de julho de 1929 anuncia os serviços da companhia localizada na Praça da Sé ${ }^{48}$ :

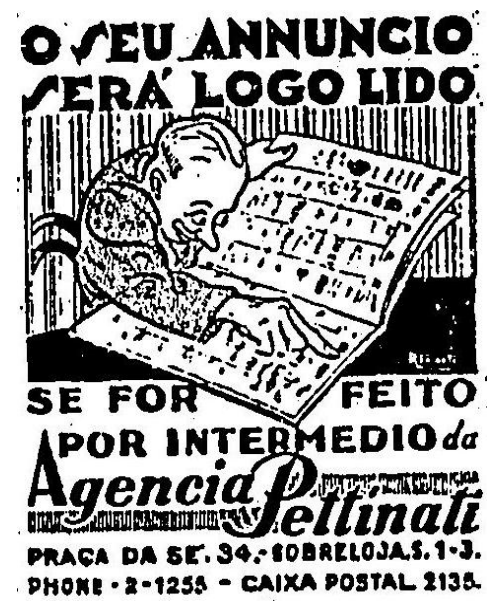

A Pettinati foi pioneira da propaganda política no país, elegendo Julio Prestes, em 1929. Com esta ação, a publicidade institucionaliza em torno das agências uma prática que já existia anteriormente. O trabalho de construir e propagar mensagens comunicacionais para conquistar a simpatia ao conjunto de ideias de um candidato e garantir votos era comum em atividades pré-eleitorais. A agência agregará valor à prática ao formalizar e organizar essas estratégias como uma forma específica de publicidade, que necessita de profissionais gabaritados para realizá-las. Hoje, a propaganda política é alvo de muitos estudos na área de marketing, que oferece técnicas específicas para a elaboração das narrativas em diferentes plataformas (Gomes, 2010).

Apesar dos esforços comunicacionais, o último presidente da República Velha do Brasil não chegou a tomar posse por conta da Revolução de 1930, que levou Getúlio Vargas ao poder. Em 1937, a agência foi encarregada do plano geral da Grande Exposição Internacional Comemorativa da Imigração Italiana, realizada em São Paulo. A empresa também fez a primeira propaganda de condomínio do país, com o plano do edifício Imperator, anunciado na primeira página do Correio da Manhã. A novidade deu certo e apareceu com frequência em muitas agências do Rio e de São Paulo (Rabelo, 1956).

No auge de sua atuação, a Pettinati reuniu as lucrativas contas da Phillips do Brasil, da Refinaria de Óleos Brasil S.A. e da Cia. Plástica Plavinil S.A.,

\footnotetext{
${ }^{48}$ Fonte: Blog Reclames do Estadão. www.estadao.com.br
} 
responsáveis por $70 \%$ do faturamento da empresa, além dos Laboratórios Baldassari, Cica, Sabão Palatino e Cigarros Flórida, cujo proprietário, Eugênio Freyenfeld, preferiu recorrer à publicidade do que procurar um banco para resolver os problemas financeiros de sua fábrica (Rabelo, 1956). O empresário precisava vender rapidamente os estoques para se manter no mercado e conseguiu a façanha com uma campanha da agência. A prosperidade foi tanta que a agência chegou a recusar clientes (Rabelo, 1956).

Nestas primeiras décadas do século XX, temos a importação de modernas máquinas de impressão que possibilitam um incremento do setor gráfico, tanto da publicidade, quanto da imprensa (Boorstin, 1980). A ilustração passa a ter uma função central para os anúncios. Propagandas eram elaboradas com desenhos e textos em uma grande variedade de tipos. Muitos cartazes eram colocados em ruas movimentadas. Também as revistas ilustradas foram um importante canal de comunicação do período, justamente por oferecer espaço para a informação visual. $\mathrm{O}$ intento de instaurar uma comunicação que chegasse às massas se intensificava com a expansão dos meios. Desde a abolição da escravatura, em 1888, podemos dizer que o mercado encontra as condições para ocupar o lugar de regente da estrutura social, iniciando uma influência cultural que pretende invadir todas as experiências da vida moderna. A ampliação das técnicas de produção de narrativas e a reprodução de imagens eram determinações importantes do período. Pequenas gráficas se transformam em empresas jornalísticas, sendo responsáveis desde a produção à circulação das revistas (Civita, 1990). Para expandir o alcance junto às camadas urbanas, percebe-se claramente um esforço dos editores em cobrir suas páginas impressas com recursos visuais. Neste sentido, as revistas vêm referenciar este modelo pretensamente mais "inclusivo" e "democrático". O florescimento das revistas também significava a emergência de um consumo cultural homogeneizado, simplificado, que associava a necessidade informativa às nuances do entretenimento. Novos leitores pouco alfabetizados eram conquistados por publicações abundantemente ilustradas e repletas de caricaturas (Velloso, 2008). As notícias eram produzidas de modo a agradar o cidadão comum que começava a ter acesso a este tipo de produção cultural. Com a adesão popular às revistas fica claro uma mudança nas sensibilidades e a formação de novas redes sociais derivadas deste consumo moderno (Velloso, 2008). 
Nestes periódicos podemos observar o incremento de discursos publicitários que começavam a associar a identidade do produto à identidade do consumidor (Rocha et al, 2013a). O uso de cores chamava a atenção dos leitores, principalmente as mulheres, que se sentiam conectadas à moda europeia. Os recursos visuais ajudaram a projetar o fascínio pelas mercadorias. Com a vida urbana em transformação, fabricantes e comerciantes investiam em reclames para dar visibilidade aos seus produtos. A distância entre notícias e anúncios se tornava cada vez mais sutil, tanto pela renovação das linguagens, quanto pela entrada de novos recursos gráficos. Os anúncios coloridos de roupas femininas da Parc Royal, divulgados em cenários de esportes nobres como tênis ou turfe, já apontavam para a rotatividade da indústria da moda, fomentada pela propaganda. As "exposições de verão" e os "novos catálogos" expressavam a efemeridade e alternância que a produção assume nas sociedades industriais, a fim de prosperar o mercado (Abril Cultural, 1980). As revistas se firmavam no consumo da mulher elitizada, por ser um veículo atualizado com as novidades internacionais. Ilustrações de mulheres sofisticadas, bem-vestidas e cheias de joias continuam a aparecer nas propagandas de meias e perfumes, como podemos observar nas imagens publicadas na Revista da Semana em 1926 e 1927, respectivamente ${ }^{49}$ :
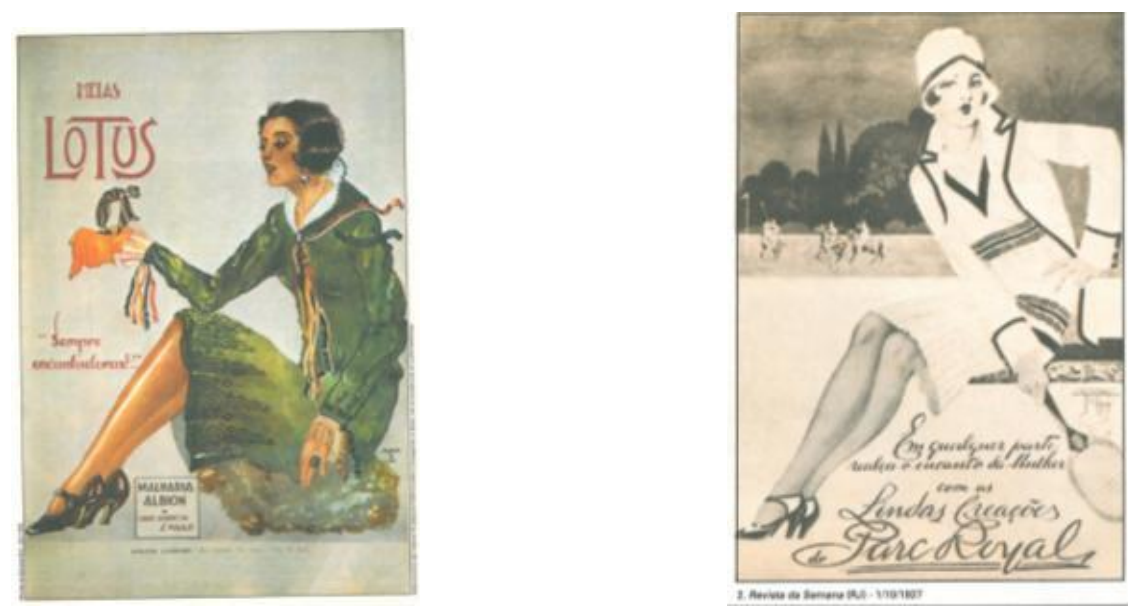

Desta forma, as mensagens dos anúncios impressos nas revistas e jornais estimularão códigos de conduta através das simbologias atribuídas aos bens. Neste

\footnotetext{
${ }^{49}$ Anúncios para mulher elitizada. Fonte: Coleção 100 Anos de Propaganda - Abril Cultural, 1980.
} 
período, temos o aparecimento de fogões a gás e chuveiros elétricos que multiplicam os confortos da vida doméstica. O impulso da indústria de eletrodomésticos será acompanhado pela publicidade, que passa a construir narrativas subliminares valorizando o status que a aquisição destes bens representava no âmbito social. O prestígio dos objetos ultrapassa suas utilidades práticas. A noção de felicidade através do consumo será explorada nas mensagens persuasivas que produziam novos simbolismos em torno de hierarquias sociais. $\mathrm{O}$ posicionamento do mundo dos bens e serviços trazido pelo universo dos anúncios começa a dividir e organizar também o mundo social, definindo a posição em que se encontram os atores sociais. Para Baudrillard (2010 [1970]) nasce uma nova mitologia, em que os objetos passam a ser regidos por signos arranjados culturalmente. A abundância e a multiplicação de objetos e mensagens orquestrados pelos sistemas de comunicação deram forma a uma coletividade orientada pelos significados e simbologias do universo do consumo. As mensagens incitarão a realização absoluta, a busca da felicidade através da compra.

Ao trabalhar com o campo da persuasão, a narrativa publicitária tem a função de signo que instiga conquistas ligadas a um determinado padrão social. Os objetos passam a ser componentes ativos na relação com os sujeitos, impulsionando desejos contundentes, determinantes para esta relação. $\mathrm{O}$ indivíduo contemporâneo já não vive sem os seus suportes materiais, que são fundamentais para a formação da sua subjetividade (Latour, 2007). Assim, o universo social passa a se organizar de acordo com hábitos de consumo que determinarão os estilos de vida moderno-contemporâneos.

$\mathrm{Na}$ esfera do consumo homens e objetos adquirem sentido, produzem significações e distinções sociais. Pelo consumo, os objetos diferenciam-se diferenciando, num mesmo gesto e por uma série de operações classificatórias, os homens entre si. O consumo é, no mundo burguês, o palco das diferenças. O que consumimos são marcas. Objetos que fazem presença e/ou ausência de identidade, visões de mundo, estilos de vida. Roupas, automóveis, bebidas, cigarros, comidas, habitações, enfeites e objetos os mais diversos não são consumidos de forma neutra. Eles trazem um universo de distinções. São antromorfizados para levarem a seus consumidores as individualidades e universos simbólicos que a eles foram atribuídos. No consumo, o objeto se completa na sua vocação classificatória. (ROCHA, 1985: 67) 
Em meio à formação de uma sociedade que incitava a realização pessoal através dos bens de consumo, o negócio da propaganda também foi referenciado pelos movimentos artísticos que ganharam a cena cultural a partir dos anos 1920 . O Surrealismo, movimento artístico e literário que nasce em Paris, liderado pelo poeta e crítico André Breton, ganha dimensão mundial ao expressar o susto e a irracionalidade no Pós-Guerra. Com artistas anteriormente ligados ao Dadaísmo ${ }^{50}$, o movimento tem forte influência da psicanálise freudiana e dará ênfase ao papel do inconsciente na produção cultural. Neste âmbito, percebemos a ingerência da magia e do plano dos sonhos nas manifestações artísticas, uma vez que o movimento combatia o racionalismo. Entre seus maiores expoentes estão o dramaturgo Antonin Artaud, o cineasta Luis Buñuel e os pintores Max Ernst, René Magritte e Salvador Dali (Rebouças, 1986).

Estes ares modernizantes do velho continente impactam os campos da arte e da comunicação no Brasil, principalmente com a Semana de Arte Moderna, em fevereiro de 1922. A emergência de novas disposições estéticas, a renovação de linguagens, a ruptura com os padrões artísticos anteriores fariam do evento um marco histórico na composição da identidade brasileira. Sob a liderança de Mário de Andrade, Oswald de Andrade e Menotti Del Picchia, o movimento teve um cunho político forte ao criticar e revolucionar os conceitos vigentes na arte, no teatro, na pintura, na poesia e na música. A repulsa ao modelo clássico de inspiração internacional proporcionou o que chamamos de "Modernismo Brasileiro", incitando a adoção de pilares artísticos genuinamente nacionais (Velloso, 2010). A historiadora Monica Velloso (2008) destaca a importância das revistas ilustradas no discurso do modernismo, já que as publicações traziam uma estética visual nova para a imprensa do período, aglutinando noções da cultura art nouveau, com influências de outros movimentos culturais, como futurismo, surrealismo, romantismo e simbolismo. Ainda assim, era comum encontrar em anúncios de anos seguintes procedimentos poéticos rejeitados pelos modernistas, como no epigrama da Camisaria Marvelo, publicado na Revista $O$ Cruzeiro, em 1930: "Neste apuro de elegância. Não existe dissonância. Sou conquistado, sou belo. E toda a minha atração. Confesso de coração. É o colarinho Marvelo!" (CARRASCOZA; Hoff, 2009: 700). Ou mesmo nos versos do creme dental Odol,

\footnotetext{
${ }^{50}$ Movimento artístico que surge no auge da Primeira Guerra Mundial, em 1916, em Zurique, na Suíça, para criticar o irracionalismo do período e os padrões da arte estabelecidos.
} 
de 1931, também anunciado nas páginas de O Cruzeiro: "Dentes que enfeitem o riso. Com brilhos claros de sol. Pouco, para isto, é preciso: A Pasta e o Líquido Odol.”(CARRASCOZA; Hoff, 2009: 700).

A quebra de paradigmas modernista também marca o início do período de ascensão e liberdade da mulher nas sociedades ocidentais. Em 1924, o clima de liberdade e transgressão dos chamados "anos loucos" se refletia em alguns anúncios, entre eles o da linha Reveillon, da Camp Joalheria, publicado na Revista da Semana, que trazia o desenho de uma mulher se exibindo com um vestido decotado e joias ${ }^{51}$.

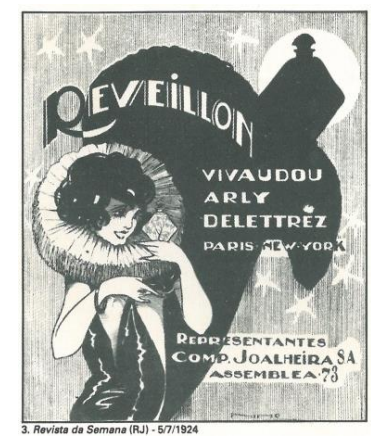

Sem a angústia da Guerra o lema era aproveitar a vida. O entusiasmo pela cena noturna aumenta, e os cabarés franceses influenciavam a cultura mundo afora, ditando novos ritmos como o jazz, o charleston e o foxtrot. As saias das mulheres independentes ficaram mais curtas, os cabelos foram cortados como no filme La Garçonne (França, 1923), os olhos marcados de preto e os lábios vermelhos formavam um desenho em forma de coração. O cigarro como expressão de liberdade e afirmação da mulher frente ao mundo masculino aparece em 1929 nos eventos norte-americanos, depois internacionalizados, conhecidos como Torches of Freedom. O ato de fumar em público era considerado uma forma de protesto e luta pela igualdade com os homens. Ainda não se admitia mulheres fumando em ambientes sociais, mas nos reclames era comum vê-las posando com um cigarro nas mãos, como na propaganda do cigarro La Reine, veiculado na Revista Eu Sei Tudo, em 1919, em que uma mulher muito elegante aparece com um cigarro nas mãos (Abril Cultural, 1980). Uma curiosa parceria entre política libertária e práticas de consumo. Abaixo o slogan determinava: o cigarro chic $^{52}$.

\footnotetext{
${ }^{51}$ Fonte: Coleção 100 Anos de Propaganda - Abril Cultural, 1980.

${ }^{52}$ Fonte: Coleção 100 Anos de Propaganda - Abril Cultural, 1980.
} 


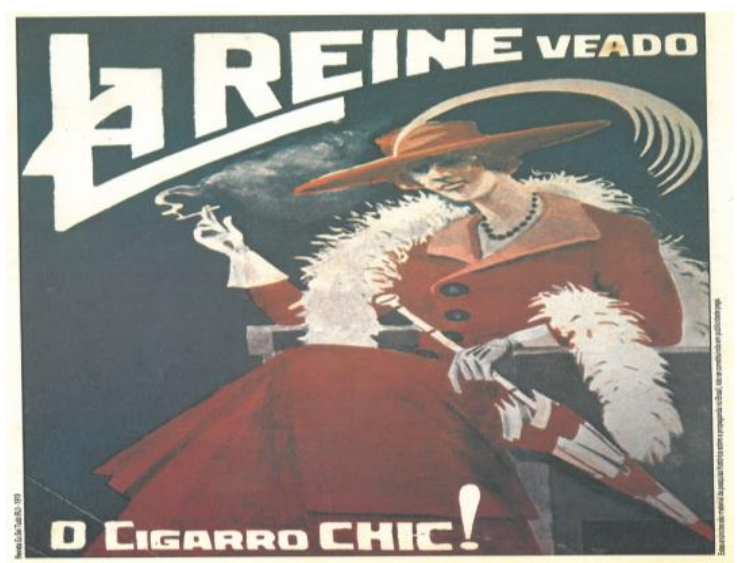

A atmosfera de prosperidade recheada de facilidades trazidas pela tecnologia e indústria do consumo foi ainda mais propagandeada com a chegada do rádio ao país. O governo buscava estimular o viés nacionalista, uma vez que completávamos cem anos da Independência do Brasil, marco histórico que merecia ser comemorado em grande estilo. A efeméride histórica serviria para mostrar ao mundo que estávamos inseridos em uma esfera civilizada. O rádio, que transmitia mensagens faladas, viria a trazer o clima de bonança que o governo buscava incitar, e seria a plataforma ideal para divulgar as maravilhas da indústria de consumo e lazer que começava a assumir um caráter massivo no Brasil.

Em sete de setembro de 1922 temos o início da grande aventura artística e comercial do rádio. Ainda em caráter experimental, o presidente Epitácio Pessoa usa o dispositivo para proferir o discurso em comemoração pelo centenário da Independência. Empresários norte-americanos instalaram uma antena no topo do Corcovado para que a tecnologia da radiodifusão pudesse ser testada no país. A palavra do presidente chegou ao público presente na Exposição Internacional do Rio de Janeiro. A mostra, enorme para os padrões brasileiros, foi montada na área do Morro do Castelo, no centro da cidade, e contou com quinze pavilhões estrangeiros e mais de dez mil expositores (Freitas, 2011). Entre os principais pavilhões ali construídos está o edifício que hoje abriga o Museu Histórico Nacional. Oitenta aparelhos receptores de rádio foram importados e o alcance das ondas radiofônicas chegou até às praças públicas de Niterói, Petrópolis e São Paulo (Freitas, 2011).

Paralelo à euforia governista, vale destacar que movimentos descontentes com a situação política do país ganhavam fôlego. O Tenentismo, séries de rebeliões de jovens oficiais de baixas e médias patentes do Exército, marcou o início da década. Os tenentistas queriam o fim do voto de cabresto, do voto 
secreto e lutavam por uma reforma na educação pública. As contestações não conseguiram resultados imediatos, mas mantiveram acesa a chama da revolta contra o poder das oligarquias, representado pela política do café com leite alternância entre os Estados de Minas e São Paulo no Governo Federal - e abriu caminho para a Revolução de 1930, processo político que culminou com o término do sistema oligárquico da República Velha.

Após a transmissão experimental de Epitácio Pessoa, o Governo Federal autoriza a concessão pública para a fundação da primeira emissora de rádio do Brasil: a Rádio Sociedade do Rio de Janeiro (Rádio MEC), inaugurada em 23 de abril de 1923, no pavilhão doado pela Tchecoslováquia, na Rua Santa Luzia, em frente à Santa Casa de Misericórdia (Prado, 2012). A emissora fora criada para atuar sem fins comerciais. Para Roquette-Pinto, empreendedor do veículo, o rádio possuía um caráter educador e modernizador da cultura (Prado, 2012).

O entusiasmo pela tecnologia se multiplicou e já em 1925 funcionavam a Rádio Educadora Paulista, a Rádio Clube do Brasil, a Rádio Clube da Bahia e a Rádio Clube Hertz, no interior de São Paulo. Ao fim de 1930 tínhamos 21 emissoras em operação. A programação era mantida por sociedades de amigos e doações de ouvintes e seguia um caráter elitista com música clássica, palestras culturais, recitais de poesia, concertos e óperas. O rádio ainda estava longe de ser um meio popular. Em 1931 são vendidos os primeiros aparelhos com o nome das estações no dial. Dois anos depois, em 1933, a Rádio Educadora de Campinas abre espaço para o jornalismo (Leite, 1990). A Rádio Nacional do Rio de Janeiro (PRE-8), fundada em 1936, marcou uma fase de glória do rádio, com programas de prestígio, como o vespertino jornal A Noite, as radionovelas e os shows de auditório. As jogadas de Leônidas da Silva, o "homem-borracha" da Copa do Mundo de 1938, foram narradas pelo locutor Gagliano Neto, direto de Estrasburgo, na França, estreando a transmissão internacional no país (Leite, 1990).

O Decreto-lei $n^{0}$ número 21.111, de 01 de março de 1932, autoriza a veiculação de publicidade no rádio. Mas o primeiro impacto da medida não foi a venda de um produto e sim de uma ideia. A Rádio Record de São Paulo se transforma no grande veículo da Revolução Constitucionalista de 1932 com Cesar Ladeira que, ao som do hino "Paris Belfort", aclamava a ideologia do levante. O locutor foi um dos responsáveis pela popularização do veículo, criando elencos 
remunerados e exclusivos, que serviram de base para os futuros programas de humor, auditório e dramaturgia (Leite, 1990).

A força do rádio já transformava definitivamente a política. Nas décadas de 1930 e 1940, Hitler usou principalmente o rádio pra propagar a ideologia nazista. Os inflamados discursos do líder alemão eram muitas vezes transmitidos por potentes aparelhos que foram espalhados com alto-falantes nos postes públicos com o propósito de emocionar a população. As mensagens simbólicas intensivas surtiram efeito provocando a adesão de milhares de alemães ao partido e contribuindo para um dos maiores genocídios da história (Longerich, 2014). O nazismo resultou em uma verdadeira guerra psicológica conduzida por técnicas de dirigir as massas, a ponto de os exércitos alemães não precisarem disparar um só tiro, como ocorreu na tomada de Oslo (Rabelo, 1956).

Durante a Segunda Guerra Mundial, uma verdadeira "guerra no ar" foi travada em paralelo ao conflito armado. As conferências feitas pelo primeiro ministro inglês Winston Churchill na câmara dos comuns eram retransmitidas mundo afora pela Rádio $B B C$, motivando as populações em guerra. $\mathrm{O}$ general francês Charles de Gaulle também usou o rádio para apelar aos militares franceses que se juntassem a ele em Londres. Direto do Japão, as mensagens da "Rosa de Tóquio" rodaram o mundo. Através das ondas da Rádio Tóquio, a americana de origem japonesa Iva Toguri D'Aquino transmitiu informações sobre falsas derrotas dos Aliados e conclamou os soldados americanos a desistir da guerra. A rádio nipônica conseguia invadir as transmissões da $B B C$ de Londres e da "Voz da América"53.

Aqui no Brasil, Getúlio Vargas, recém-chegado ao poder pela Revolução de 1930, logo descobre esse potencial de comunicação do rádio e cria o Departamento Oficial de Propaganda (DOP), mais tarde transformado em Departamento de Imprensa e Propaganda (DIP) para fiscalizar e censurar as emissoras. Com a "Hora do Brasil”, lançado em 1935, o locutor Luís Jatobá podia divulgar os atos do poder executivo. Em 1937, o programa é usado para anunciar a implantação do Estado Novo, e a partir de 1938 torna-se obrigatório, sempre às

\footnotetext{
53 Fonte: Acervo Jornal $O$ Globo, publicado em 11/10/2013. Disponível em: http://acervo.oglobo.globo.com/em-destaque/pelo-radio-rosa-de-toquio-conclamou-soldados-doseua-desistirem-da-guerra-10335543
} 
19 horas. Em 1971, o General Médici muda o nome do noticiário para $A$ Voz do Brasil (Prado, 2012).

A historiadora Marialva Barbosa (2007) destaca que a construção da linguagem da propaganda do governo figurava em torno de Vargas, sempre colocado como o "pai dos pobres", líder das massas trabalhadoras, fortalecendo o papel do Estado como instituição protetora da vida social, incitando uma subordinação alienante:

Assim, Vargas, em todas essas campanhas e peças promocionais, é sempre o sujeito da ação: ele é que cria, determina, estabelece, assina, manda, executa. Nos pronunciamentos, a preocupação central é mobilizar o povo transformado em trabalhador e os textos políticos estruturam-se em torno da construção de uma relação entre povo e Estado-Nação, personificada na figura do líder. Nesse sentido, o pai dos pobres é também o pai do povo trabalhador. E é nessa posição, poderosa e, ao mesmo tempo, generosa que Vargas pede e exige total obediência e sacrifícios. Constrói-se a ideia de nação como espírito comum, o que favorece a autoridade em detrimento da solidariedade, tendo o Estado papel tutelar. (BARBOSA, 2007: 120)

O sucesso do rádio atraiu muitos investimentos estrangeiros, que abriram caminho para o surgimento de uma indústria fonográfica, com maior número de artistas e gravadoras. $\mathrm{O}$ meio passou a divulgar e impulsionar a carreira de alguns cantores, que se tornaram muito populares e atraíram legiões de fãs para os palcos das emissoras ou para os shows nos famosos cassinos. No Rio de Janeiro, a notoriedade dessas casas de espetáculos e jogos é associada a um período de glamour e efervescência cultural. Grandes nomes do cenário musical brasileiro e internacional se apresentaram nos cassinos e boates cariocas (Prado, 2012).

Com isso, o governo passou a distribuir maior número de concessões para emissoras. Na década seguinte, o rádio se consolida como a mídia mais popular do Brasil, interligando o país através de suas mensagens e atraindo grandes públicos para os auditórios. No início, a programação era gravada na sede das emissoras e retransmitida para outras cidades. O fascínio das ondas curtas e médias irá gerar uma comunicação massificada, amparada financeiramente pelo setor publicitário, que passou a investir suas maiores fatias orçamentárias na propaganda radiofônica (Ferraretto, 2007).

Desde o começo do rádio no país, uma ligação intimista foi desenvolvida entre as emissoras e as agências de publicidade. Alguns programas levavam o 
nome de seu patrocinador - como o Repórter Esso - e era proibido colocar anúncios do concorrente em seus intervalos. Os textos publicitários eram elaborados pelas agências e interpretados pelas potentes vozes dos locutores. As agências multinacionais aqui sediadas, como a McCann-Erickson e a JWT, chegavam a aplicar até $40 \%$ de seus orçamentos no rádio (Leite, 1990). Essa relação estreitar-se-á ainda mais a partir da década de 1940, com a chamada época de ouro do rádio. Os apelos do som e a imaginação que o áudio desencadeava nos consumidores fizeram com que o setor publicitário se aliasse definitivamente ao mundo do rádio, tornando-se seu maior patrocinador (Ferraretto, 2007).

A cada novo empreendimento da indústria das comunicações, a publicidade ganhava diretamente novos contornos. O rádio foi uma plataforma que modificou substancialmente os processos produtivos nas agências e as estratégias de planejamento das campanhas. Novas competências, habilidades e tecnologias precisaram rapidamente ser incorporadas pelos profissionais que estavam acostumados a pensar anúncios para os diferentes formatos de publicação impressa, baseados em processos rotineiros. Desta forma, a necessidade de estratégias planejadas conjuntamente pelos diversos atores sociais nas agências foi determinante para a criação de anúncios e formatos no rádio. Becker (1977) expõe a dependência de uma abordagem ou contexto externo para o entendimento e fabricação de um objeto artístico. A cadeia cooperativa não é composta apenas pelo artista criador, como também por um mercado distribuidor e pelo público (Becker, 1977). Assim, o artista é visto como um elemento dentro de um sistema em que as convenções determinam procedimentos de conduta e invenção. Fora dos sistemas, o artista teria muitas dificuldades de transformar sua obra em um produto social. Tais convenções sofrem adaptações a cada novo contexto social, sem que isso ameace a posição do campo. As convenções, embora padronizadas, não são rígidas ou imutáveis (Bourdieu, 1983 [1976]).

$\mathrm{O}$ encadeamento de elementos nas agências foi reforçado devido à rapidez com que a comunicação radiofônica conquistou a sociedade brasileira. $\mathrm{O}$ rádio trouxe a ideia de velocidade e mudança dos processos sociais (Ferraretto, 2007). A tecnologia ultrapassou barreiras geográficas e disseminou uma capacidade de comunicação que até então não tinha sido vista em nenhum outro meio. Acompanhar essas transformações da percepção do público consumidor e do mercado foi urgente para vender produtos com eficiência. Com o rádio, a 
publicidade se estrutura como a grande fomentadora e idealizadora dos modelos de programação e dos aportes financeiros necessários para gerir o campo da mídia. O rádio ampliou e consolidou a publicidade como o pilar administrativo dos meios de comunicação.

Além do rádio, vale enfatizar outros empreendimentos da mídia impressa que marcaram o período e se tornaram grandes expoentes da história da comunicação no Brasil. Em 29 de julho de 1925, surge o jornal $O$ Globo na cidade do Rio de Janeiro. No entanto, Irineu Marinho, seu fundador, morre apenas 21 dias após a inauguração do periódico, o que leva seu filho, Roberto Marinho, à frente dos negócios. No início, Roberto deixou a empresa nas mãos do jornalista Euclydes de Matos, amigo pessoal de seu pai. Em 1931, com a morte de Euclydes, assume o controle da empresa. Era o início de um império de comunicações que se tornaria um dos maiores do mundo com a união de empresas atuando em diversos setores das comunicações, como a TV Globo, Rádio Globo, Editora Globo, entre outras ${ }^{54}$. Atualmente as Organizações Globo, lideradas pela Rede Globo de Televisão, são o maior conglomerado de mídia da América Latina e um dos maiores do mundo.

$O$ Globo inovou em muitos aspectos e hoje é um dos periódicos mais prestigiados do país, ao lado da Folha de S.Paulo, Correio Brasiliense e O Estado de S. Paulo. Em 1936, o jornal lançou a primeira telefoto da imprensa brasileira com o registro da nadadora Piedade Coutinho na final dos 400 metros nado livre nas Olimpíadas de Berlim. O feito inédito no esporte brasileiro ganhou a manchete do dia 17 de agosto daquele ano: "O GLOBO inaugura a telephotographia no Brasil - Um instantaneo sensacional de Piedade Coutinho na final dos 400 metros livres" 55 . Na Segunda Guerra Mundial, o jornal levava informações do Brasil para soldados brasileiros na Europa com o Globo Expedicionário. Para concorrer com a revista Mirim, de Adolfo Aizen, publicada como suplemento jovem no jornal A Nação, O Globo lança a sua primeira revista, O Globo Juvenil, em 1937, alavancando a venda de histórias em quadrinhos. Logo depois publica, em 1939, O Gibi. O sucesso da revista faz do termo "gibi" (que na época significava moleque, negrinho) sinônimo de "revista em quadrinhos" no país.

\footnotetext{
${ }^{54}$ Fonte: www.memoriaglobo.com.br

${ }^{55}$ Fonte: Acervo digital Jornal O Globo. Ano 1936.
} 
Em 10 de novembro de 1928, os Diários Associados, comandados pelo jornalista Assis Chateaubriand, lançam a revista $O$ Cruzeiro (no início se chamava apena Cruzeiro), que seria a principal publicação ilustrada das próximas três décadas. A revista agradou com uma linguagem inovadora que priorizava o uso de ilustrações, charges, grafismos e fotografias que incrementavam suas "grandes reportagens". A parceria do jornalista David Nasser com o fotógrafo Jean Manzon foi fortalecida pelo formato. Nos anos 1940, a dupla foi responsável por reportagens de grande repercussão, que misturavam viagens exóticas, opinião do repórter, entrevistas e fotos de alta qualidade. Com o sucesso da publicação, nas décadas de 1940 e 1950, ganha popularidade no país um jornalismo de variedades, unindo temas factuais a amenidades. O tratamento das notícias era leve, apresentando muitas imagens, com fotos ocupando páginas inteiras. Entre seus diversos assuntos, a revista mostrava a vida das celebridades de Hollywood, cinema, esportes e saúde. Seções de charges, política, culinária e moda completavam o cardápio de temas diversificados. Com a cobertura do suicídio de Vargas, em agosto de 1954, a revista vendeu 720.000 exemplares, um número impressionante (Morais, 1994), sobretudo quando se pensa que mais de 50\% da população brasileira, na época, eram de analfabetos ${ }^{56}$. O Cruzeiro se tornou referência de comportamento e moda, incentivando um consumo amparado na distração.

Os meios de comunicação passam a incorporar cada vez mais o entretenimento como valor editorial. Ao nos distanciarmos dos jornais de cunho político e padrão opinativo da virada do século, as estratégias do "lazer", do "passatempo" que visavam atrair grandes audiências se constituem como um valor-notícia dos organismos de informação, uma vez que impulsionavam vendas (Aguiar, 2008). A lógica mercantil publicitária, de produzir mensagens que estimulem o consumo, se firma ideologicamente como filosofia das empresas de comunicação e se vincula também à construção das notícias. O espaço destinado às principais manchetes da imprensa estaria ligado a capacidade de "divertir" ou “distrair" um fato. A ideia de que o entretenimento não exigia nenhum esforço intelectual para ser apreciado, de que respondia apenas à lógica das sensações,

\footnotetext{
${ }^{56}$ www.ibge.gov.br
} 
associou essa estratégia às produções culturais, buscando um consumo baseado na função de lazer (Debord, 1997 [1967]).

Com a expansão dos meios, as imagens começam a ocupar o imaginário social significativamente. Além das revistas ilustradas e do crescimento da fotografia na imprensa, o aparecimento dos tabloides, em meados da década de 1930, confirmou o peso das imagens como valor editorial. Esses jornais, produzidos em tamanho um pouco menor do que os diários tradicionais, reinaram com suas enormes fotos e gráficos e uma quantidade pequena de texto informativo, em geral de caráter apelativo. A Folha da Tarde, de Porto Alegre, foi o primeiro tabloide a circular no Brasil, em 1936 (Bahia, 1990). Para Guy Debord, estávamos inseridos em um tempo em que a “(...) relação social entre as pessoas passou a ser mediada por imagens." (DEBORD, 1997 [1967]: 14).

Os tabloides, as revistas ilustradas, os modernos jornais e o rádio transformaram nossa experiência social, ajudando a moldar uma sociedade midiatizada, imagética, amparada no entretenimento e consumo. Cada um desses dispositivos de comunicação trouxe novos papéis, acordos e protocolos para o campo da publicidade. Como coloca Becker (1977), cada convenção traz uma nova estética. As convenções são moldadas com base na cultura vigente em cada sociedade. Neste sentido, quanto maior a influência dos meios de comunicação no social, mais elaboradas e sofisticadas se tornaram as convenções para a produção dos anúncios dentro das agências. As tecnologias da comunicação alavancaram os mercados e reorganizaram a maneira de criar produtos sociais, assim como ampliaram e legitimaram o campo da publicidade em si. Novas vozes ganham relevância e exposição, projetando identidades culturais nos planos profissionais e pessoais.

\section{3 - A chegada da indústria norte-americana}

Na medida em que o capitalismo alargava sua influência econômica e cultural, as empresas levavam seus negócios para fronteiras cada vez mais distantes. No plano político internacional, a ascensão de Hitler e Mussolini ao poder semeava novos confrontos, que desembocariam em mais uma guerra 
mundial. No Brasil, a Revolução de 1930 e a Revolução de 1932 trouxeram as condições ideais para Vargas implantar seu projeto centralizador e alinhado com as ditaduras europeias. O movimento armado cívico de 1932 em São Paulo tinha como objetivo derrubar o governo provisório e conseguir a promulgação de uma nova Constituição. De certa forma, os paulistas queriam retomar a supremacia da República Velha - alternância do poder executivo entre os Estados de Minas e São Paulo - de que gozavam desde 1891 e que fora perdida com a ascensão de Vargas. Depois de 87 dias de combates, entre julho e outubro, a liderança revolucionária paulista se rende frente ao poderio das tropas de Getúlio, que invadia paulatinamente as cidades do interior e impunha bloqueios ao Porto de Santos, asfixiando a economia estadual (Bastos; Fonseca, 2012).

Nos setores urbano e social importávamos os modelos norte-americanos, que estabeleciam condições para um mercado de consumo crescente. As cidades assumiam uma nova estrutura geográfica de moradia e trabalho com uma ocupação vertical marcada pelos primeiros arranha-céus. A economia apostava no desenvolvimento da indústria de bens de consumo direcionada principalmente para as classes médias emergentes que se expandiam nos grandes centros (Bastos; Fonseca, 2012).

Os novos mercados em formação e a ausência de concorrência atraíram grandes empresas americanas ao país. De modo complementar a esse processo, agências também eram convocadas para dar suporte e promover as marcas nos novos ambientes territoriais e espaços de comunicação. Kodak, Phillips, General Electric foram algumas marcas que apostaram no mercado brasileiro. Com elas, as primeiras agências internacionais de propaganda se estabeleceram em solo nacional (ABAP, 2005).

A expansão da indústria automobilística por volta dos anos 1920 impulsionou a chegada de técnicas de marketing ao Brasil. O modelo norteamericano de propaganda comercial começa a dominar o setor. Em 1919, a Ford constrói sua primeira unidade de montagem no país. Em 1925, a General Motors chega com técnicas de vendas extremamente avançadas para a época. A companhia tinha seu próprio departamento de propaganda que apresentou ao mercado nacional novos planos de ações. A Divisão de Propaganda da General Motors representou um verdadeiro divisor de águas na história da publicidade no Brasil, uma vez que trouxe um modelo de orientação profissional ainda não 
experimentado aqui. $\mathrm{O}$ setor foi montado para atender a demanda crescente de anúncios que prosperava ano após ano devido ao enorme volume de vendas de veículos. No inicio, contava apenas com cinco funcionários que encomendavam e forneciam folhetos, cartazes, brindes aos revendedores, além de publicar um boletim mensal para a companhia. Com novas necessidades de propaganda, um desenhista e a empresa de Armando D'Almeida foram contratados. A A. D’Almeida Serviços de Publicidade somente distribuía os anúncios para os jornais. Os textos e as ilustrações eram criados na própria GM. Em 1927, foi preciso admitir novos funcionários, e a Divisão chegou a ter 34 colaboradores entre desenhistas, redatores, layoutmen e assistentes. Nesta época, a empresa funcionou como uma grande escola de propaganda e investiu em técnicas que estimulassem a equipe a adquirir gosto pela profissão. $\mathrm{O}$ setor passou a receber livros, catálogos, revistas técnicas e manuais vindos diretamente do Departamento Internacional de Nova Iorque. O processo foi liderado pelo gerente norteamericano Mr. Grout (Reis, 1990). Aqui podemos notar como se dão os conflitos travados entre os agentes sociais dentro de um campo, detalhados pela teoria de Bourdieu (1983 [1976]). Os antigos e mais experientes - no caso, os americanos se empenham em determinar, adequar, validar, legitimar suas representações, a fim de estabelecer uma conduta de comportamento e submissão que os mantenha na posição de liderança em que se encontram. A luta simbólica irá demarcar o que pertence ou não àquela indústria, quais os valores e rituais devem ser seguidos. Assim, a socialização e as significações são planejadas, fixadas e instituídas pelo poder simbólico e traduzidas como um habitus, o que torna plausível a reprodução de uma determinada ordem (Bourdieu, 1983 [ 1976]).

Com vultuosas verbas para propaganda, a $G M$ organizou ações pioneiras, como os salões do automóvel, evento para mostrar as novidades do mundo automobilístico - com plataformas giratórias, luzes cambiantes, filmes, concursos - malas-diretas para os clientes e outdoors de estrada (Ramos; Marcondes, 1995). O departamento também marcou época com as inovações no setor gráfico. Cadillacs, Buicks e Chevrolets eram apresentados em coloridos cartazes com impressões modernas. Para atender os 300 revendedores da $G M$ em todo o país, o Departamento de Propaganda passou a fornecer anúncios para os jornais do interior. A chegada do Chevrolet Pássaro Amarelo e sua prova de resistência do motor foi anunciada em grande estilo pelo rádio em forma de comunicado 
telegráfico. A Divisão da $G M$ foi desativada com a chegada da $J W T$ ao país, que assumiu a publicidade brasileira da General Motors, já que também era responsável pela comunicação da empresa no resto do mundo (Cadena, 2001).

Com o encerramento das atividades da Divisão da $G M$, os 34 profissionais do setor foram dispensados. Com isso, surgiu a Empresa Nacional de Propaganda formada pelos subgerentes daquele departamento, que aprenderam as modernas estratégias publicitárias com os americanos. A agência durou pouco, uma vez que buscou apenas grandes anunciantes e não tinha capital para empregar as trabalhosas técnicas internacionais (Cadena, 2001).

A $J W T$ foi a primeira agência internacional a entrar no Brasil, em abril de 1929. Seu funcionamento só foi autorizado após a publicação do Decreto $\mathrm{n}^{\circ}$ 19.111 no Diário Oficial da União, em fevereiro do ano seguinte (Abreu; Paula, 2007). Instalada em São Paulo, na Praça Ramos de Azevedo, entre as ruas Barão de Itapetininga e 24 de Maio, a $J W T$ veio cumprir uma exigência da sua cliente General Motors, de abrir escritórios próprios em todos os países em que a GM tivesse filiais.

Os negócios prosperaram de vez a partir de 1935, uma vez que os primeiros gerentes não tinham muita experiência. O escritório do Rio de Janeiro foi aberto em 1932, sob a gerência de Charles Albert Ullmann, que permaneceu no comando até o fim dos anos 1940. Mesmo com a sede carioca, São Paulo concentrava as atividades de criação de anúncios, produção e mídia para o Rio. O atendimento era o principal foco da filial (Reis, 1990).

A Divisão de Propaganda da $G M$ foi a principal fornecedora de mão de obra qualificada para a JWT. Os quinze funcionários da agência foram segmentados entre os setores de Criação, Mídia, Produção, Expedição e Finanças. O trabalho desenvolvido na matriz brasileira atraiu clientes importantes, como a Kodak, Brahma, Tissot, Sul América Seguros, Cimento Mauá, Omega, Pond's, Atlantic, Coty, Refinações de Milho Brasil (Reis, 1990). A rentável conta da multinacional Unilever foi conseguida após a agência de publicidade Lintas (abreviação de Lever's Internacional Advertising Service - Serviço Internacional de Propaganda da Lever) não encontrar funcionários experientes que pudessem realizar um trabalho de qualidade no Brasil. A agência tinha sido fundada na Inglaterra por Ivor Cooper, em 1930, quando o "Lever House Advertising" foi ampliado para outros países para atender às necessidades de propaganda da 
grande quantidade de produtos da Unilever. Os padrões exigidos pela empresa londrina não estavam de acordo com os da filial latina, o que determinou seu fechamento (Abreu; Paula, 2007). Àquela época, a JWT já operava com muita eficiência por aqui.

Desde os primeiros anos de atuação, a $J W T$ transformou o mercado de propaganda brasileiro, seja estabelecendo convenções para o campo, seja trazendo inovações tecnológicas que aprimoraram a produção. $\mathrm{O}$ florescimento da atividade no Brasil era o momento ideal para a introdução de normas e regras que legitimassem o setor e promovessem um modelo rotineiro de ação. Os profissionais que ingressavam no campo seriam então moldados, adaptados, ensinados a agir conforme as convenções estabelecidas pelos agentes organizadores, consoante os mesmos princípios elencados por Bourdieu a respeito da formação de um campo social (Bourdieu, 1983 [1976]). A teoria da ação coletiva de Becker (1977), aplicada ao mundo da publicidade, permite dizer que a agência foi a instância aglutinadora das atividades que regem a profissão, o espaço onde se realizou a interação conjunta e as lutas simbólicas de todos os elementos envolvidos no processo de confecção da propaganda. Foi o que aconteceu claramente com a atuação das agências estrangeiras no Brasil. Nesse sentido, a influência das empresas internacionais foi determinante para consolidar parâmetros de ação, papéis profissionais, direitos, obrigações, padrões estéticos, divisões de setores que seriam copiados e incorporados por outras agências brasileiras.

Iniciativas de usos das novas tecnologias da época, como a introdução da fotografia nos anúncios e o início das pesquisas de mercado, fizeram da $J W T$ um grande referencial para o campo da publicidade no Brasil. Antes da chegada dessa agência, as ilustrações de anúncios eram feitas na base de desenhos. Como a maioria dos bons desenhistas e caricaturistas trabalhava para os jornais, a publicidade ficava carente de profissionais familiarizados com a área. Para suprir essa demanda, um Departamento de fotografia foi criado e o fotógrafo Henrique Becherini começou a prestar serviços para a empresa. Becherini é apontado como um dos primeiros a se especializar no setor publicitário, já que os fotógrafos costumavam atuar em vários segmentos e muitos não queriam se arriscar por um campo pouco conhecido (Albuquerque, 1990). Fotos de personalidades brasileiras foram usadas na primeira campanha feita para a GM. Logo depois, clientes como 
Goodrich, os postos Atlantic, Blue Star Lines e Refinaria de Milho Brasil também passaram a exibir fotografias em anúncios. Em geral, a fotografia na publicidade se restringia a produtos e objetos, uma vez que as pessoas se constrangiam em atuar como modelos. Em muitas ocasiões, a solução era convencer parentes dos funcionários e até frentistas de postos a posar para fotos (Reis, 1990). As fotos coloridas também foram usadas em outdoors. O primeiro cartaz foi feito para os Encerados Locomotiva (Abreu; Paula, 2007). No entanto, a primeira fotografia colorida de propaganda em impressos foi publicada mais tarde, somente no início dos anos 1950, para um anúncio da fabricante de tapetes Tabacow, veiculado na revista Seleções (Reis, 1990).

No âmbito das investigações dos hábitos dos consumidores desde a década de 1930, a JWT sentiu a necessidade de identificar as rotinas de compras e fazer pesquisas de mídia nas bancas de jornais sobre os produto de seus clientes. Assim nasciam as primeiras pesquisas de mercado no Brasil. Em 1933, o antigo Departamento Nacional do Café (DNC), antecessor do Instituto Brasileiro do Café (IBC), encomendou um estudo inicial para conhecer as atitudes dos consumidores de café, já que o governo planejava uma campanha do produto no exterior. O publicitário Francisco Teixeira Orlandi coordenou essas ações (Abreu; Paula, 2007).

Outra medida importante para a consolidação do negócio da propaganda foi a uniformização dos descontos concedidos pelas agências neste mesmo período. A $J W T$ liderou o processo ao importar o sistema usado nos Estados Unidos. Com a ação, as agências teriam uma tabela fixa de remuneração pelos veículos, que dava um desconto de $20 \%$ sobre o preço cobrado pelas agências e ainda instituía a cobrança de uma taxa de $15 \%$ sobre o valor bruto ou $17,5 \%$ sobre o líquido. O sistema persistiu até a promulgação da Lei $n^{\circ} 4.680$, em 18 de junho de 1965 (Abreu; Paula, 2007).

A JWT também participou das primeiras organizações de classes do setor, junto com a Eclética, como a Associação Paulista de Propaganda (APP, atual Associação dos Profissionais de Propaganda) e a Associação Brasileira de Propaganda (ABP). Os objetivos das entidades civis eram “(...) trabalhar pelo desenvolvimento e enobrecimento da propaganda, elevando-a, no nosso país, no nível que a profissão já desfruta em quase todo mundo; incentivar o desenvolvimento das técnicas da propaganda pela divulgação cada vez maior dos 
benefícios que a propaganda pode trazer às indústrias, ao público, ao comércio, ao governo e ao país e defender os interesses dos que trabalham nesta profissão." (ABREU; PAULA, 2007: 33), conforme o estatuto da ABP. Em 1939, essa instituição esboçou um primeiro Código de Ética Profissional da Propaganda. A atuação das sociedades de classes foi decisiva para proteger os interesses dos profissionais e trazer bases normativas para a prática da propaganda. Estas parcerias deram ares de organização e fortaleceram os negócios publicitários frente aos poderes públicos, além de garantir maior reconhecimento civil. As entidades também promoviam cursos de formação, estudos na área, elaboravam congressos e premiações exclusivas para o setor. Logo depois de sua criação, em 1937, a ABP organizou o I Salão Brasileiro de Propaganda, no Rio de Janeiro (ABAP, 2005).

A formação de associações ou entidades organizadas evidenciam as disputas dos atores sociais para legitimar suas representações e ganhar força em seu campo (Bourdieu, 1983 [1976]). Tais sociedades civis estabeleceram classificações de signos, adequações, códigos de valores ao setor publicitário. O poder simbólico conferido pelo caráter institucional das agremiações traz status e prestígio aos profissionais envolvidos, que são vistos como agentes competentes, engajados em proteger a classe e cultivar uma conduta ética. Logo, assumem posição hierarquicamente superior em relação aos demais. Neste sentido, as associações publicitárias reúnem uma espécie de elite intelectual do setor, profissionais respeitados por suas habilidades e comprometimento na construção de funções normativas e autonomização do campo (Bourdieu, 1983 [1976]).

Os grandes centros de consumo norte-americanos também acompanhavam o desenvolvimento do mercado brasileiro. Com a histórica loja Mappin, o comércio varejista sofreu uma verdadeira revolução. O grupo, instituído na cidade de Sheffield, na Inglaterra, em 1774, chega ao Brasil em 19 de novembro de 1913. Mappin inaugura um novo conceito no país, o das lojas de departamento. A rede, considerada símbolo de modernidade por décadas, foi à falência em 1999, mas até hoje permanece na memória de muitos brasileiros. A primeira "Mappin Store" foi aberta na Rua 15 de novembro, no centro de São Paulo. A unidade mais popular foi inaugurada em 1939 na Praça Ramos de Azevedo, também no centro paulista (Bonadio, 2007). Nos andares de cada prédio funcionava um departamento que vendia um tipo de produto, como eletrodomésticos, roupas e brinquedos. $\mathrm{Na}$ 
década de 1930, a loja inovou ao decorar suas vitrines com etiquetas de preços, procedimento muito usado nos Grandes Magazines do século XIX, mas ainda novo por aqui (Rocha; Frid; Corbo, 2016). As propagandas de ofertas veiculadas em jornais eram administradas internamente e trouxeram um refinamento gráfico que influenciaria toda a comunicação do varejo em geral. Por este diálogo sofisticado com o público, o Mappin foi ponto de encontro de boa parte da sociedade paulistana até os anos 1950. A partir daí, passou a criar liquidações para atrair os consumidores. Foi também uma das primeiras empresas a oferecer crediário no país. Outras lojas se destacam neste tipo de facilidade e fizeram história, como a Mesbla, Lojas Americanas, Casas Pernambucanas, Casa Colombo (Bonadio, 2007).

Essas técnicas elaboradas de comunicação com os clientes planejadas por uma grande loja como o Mappin também ajudaram a impulsionar a consolidação das agências de propaganda, principalmente aos olhos dos lojistas. Com os trabalhos de fidelização dos clientes às marcas, as agências começam a ser vistas como grandes promotoras de vendas, indispensáveis para fazer prosperar os interesses das corporações de varejo. A sofisticação das estratégias de vendas alimentava a ideia de que era preciso ter uma empresa especializada para planejar todas as facetas do negócio.

No mesmo ano da fundação da $J W T$, a agência norte-americana Foreign Advertising Service Bureau Inc é inaugurada em São Paulo. O ex-funcionário da General Electric, Armando D’Almeida, assumiu a representação no Brasil, e o empreendimento ficou conhecido como "Companhia do Almeida". Em 1938, com o bom desenvolvimento da empresa, Almeida a transforma em sociedade anônima e muda seu nome para Inter-Americana de Publicidade S.A. A filosofia adotada era a de transparência com os clientes, por isso publicava os balanços anuais, uma forma de construir maior credibilidade em torno do negócio das agências. Mas, a medida ainda não era muito bem vista pela concorrência (Rabelo, 1956). A agência manteve por anos contas de peso como a Gillete, Café Globo, Mappin \& Webb, Mesbla, Segadaes, Indústrias Reunidas Sofá-Cama Drago (D’Almeida, 1976).

À medida que cresce o número de agências, os agentes sociais se empenham em promover inovações para marcar posição de seu empreendimento frente aos demais e tentar se sobressair como criadores de convenções adotadas 
pelo campo (Becker, 1977). O campo se constitui então como um sistema de linhas de forças que se contrastam e se unificam em cada lugar e tempo específico (Bourdieu, 1983 [1976]). Assim, o aumento de instituições traz a necessidade de diferenciação para a consagração intelectual e artística. Também com a expansão e diversificação do público consumidor, o campo ganha complexidade e intensifica sua interdependência de atores, atividades e instituições (Becker, 1977).

Neste período, outra agência norte-americana surge no Brasil com o mesmo objetivo da pioneira JWT. Em 1931, a N.W. Ayer \& Son se instala na capital paulista para desenvolver a propaganda dos veículos da Ford, até então atendida pela Eclética. Nos 12 anos em que ficou no Brasil, a Ayer promoveu um alto padrão de atendimento a seus clientes, com grandes investimentos em pesquisas. De fato, as finalidades expansionistas das companhias norteamericanas ativaram um consumo crescente no país. O mercado publicitário brasileiro foi fortemente estimulado graças às exigências destas grandes empresas que trouxeram suas agências internacionais para cá. No fim da década de 1930, a revista Propaganda registrava o funcionamento de 56 agências entre Rio e São Paulo. Entre as principais citadas estavam: Eclética; Bastos Tigre; Edanee; Empresa de Publicidade Brasil; Inter-Americana; J.W.T; Lintas; McCannErickson; N. W. Ayer \& Son; Pan America; Pettinati; Reclam; Santos \& Santos; Standard e Vaumart (Reis, 1990).

São Paulo foi a cidade escolhida como sede da Ayer, por conta da proximidade da fábrica e dos escritórios centrais da Ford. O novo negócio foi dirigido pelo major canadense Ingriff Diez Carson, ex-oficial do exército inglês (Reis, 1990). Assim como a JWT, a Ayer também contratou profissionais oriundos da Divisão de Propaganda da GM. A agência internacional pagava quatro vezes mais do que os veículos tradicionais do período, como jornais e rádios. As altas taxas de desemprego e as más condições de trabalho caracterizavam tempos difíceis para o mercado de trabalho na embrionária área da comunicação (Reis, 1990).

O escritório do Rio, aberto pouco tempo depois, sob a gerência de Aldo Xavier da Silva, contou com uma equipe de redatores que obteve muito reconhecimento do mercado, entre eles: Renato Castelo Branco, Armando de Moraes Sarmento e A. Souza e Silva (Ramos; Marcondes, 1995). A eficiência dos 
profissionais e os renomados clientes - General Electric, Light, Braford, Peggy Sage, Gessy - contribuíram para a boa fama da agência, considerada o “(...) navioescola da propaganda brasileira." (REIS, 1990: 318).

Para o Departamento Nacional do Café, a empresa teve a missão de conseguir divulgar a nossa bebida no mercado americano. Depois dos estudos iniciais sobre comportamento do consumidor feitos pela JWT, a Ayer realizou a primeira grande pesquisa de mercado no Brasil para este cliente. A investigação envolveu 12.000 consumidores, 3.000 torradores de café e revendedores de 19 estados do país (Ramos; Marcondes, 1995). Em 1933, a companhia organizou de forma pioneira um esboço de programação em rede para o rádio, quando fez uma série de programas para a Record, em São Paulo, junto com a Rádio Mayrink Veiga, no Rio, apresentando grandes artistas da época, como Carmen Miranda, Mário Reis, Gastão Formenti, George Fernandes (Reis,1990).

O serviço completo prestado aos clientes era marca registrada da Ayer. Para a Gessy, por exemplo, modernizou as embalagens, reorganizou o departamento de vendas e reformulou o departamento contábil da empresa, a fim de obter o custo exato de cada um dos produtos. Com dificuldades financeiras oriundas da Segunda Guerra Mundial e a perda da conta da Ford para a JWT, a Ayer encerrou suas atividades no Brasil em 1943 (Ramos; Marcondes, 1995).

$\mathrm{O}$ profissionalismo estrangeiro fez nascer a primeira agência brasileira estruturada conforme o padrão americano, a Standard Propaganda S.A. O nome em inglês já mostrava sua opção pelo modelo internacional. Daí em diante, esse se tornou um costume comum no campo da publicidade, o de colocar ou manter nomes em inglês, não só na denominação de agências, como também no jargão do setor, nas atividades, cargos e produtos. Briefing, brainstorming, slogan, layout, jingle, spot são alguns dos termos que nunca mais saíram do vocabulário da nossa publicidade.

Fundada em 1933, no Rio de Janeiro, a agência acertou no batismo e cresceu no mercado brasileiro, vencendo as internacionais no duelo pelas contas da Shell, Helena Rubinstein, Colgate-Palmolive, Kibon, Meias Lupo, Biscoitos Duchen, Fontoura \& Serpe, Saponáceo Radium, Hyman Rinder, Loteria Paulista, Pastilhas McCoy, Laboratórios Sanitas e Rhodia. O diretor-superintendente Cícero Leuenroth montou a empresa com a ajuda de dois sócios, Pery de Campos e João Alfredo de Souza Ramos, no edifício do jornal A Noite, na Praça Mauá. 
Cícero era filho de Eugênio Leuenroth, um dos fundadores da Eclética (Reis, 1990). O escritório de São Paulo foi instalado em seguida. Entre os primeiros clientes estavam a casa lotérica Esquina da Sorte, Casa Pratt e Eucalol. Após cinco anos de atuação, a agência já contava com grandes profissionais do mercado (Abreu; Paula, 2007).

A Standard teve expressivo destaque no meio radiofônico, tendo sido a primeira a desbravar significativamente a nova mídia. Em depoimento a Genival Rabelo (1956) para a revista Propaganda Nacional, Leuenroth orgulha-se de ter se preocupado com o potencial do veículo:

Eu sentia o interesse que as donas de casa manifestavam pelo rádio. Compreendi que o rádio lhes chegava por mais tempo e com mais familiaridade que a imprensa. Concluí que toda vez que o problema fosse vender à dona de casa, o melhor caminho seria o rádio. (RABELO, 1956: 18)

A percepção do diretor estava certa e a agência dobrou de faturamento na década de 1940. Os anúncios de rádio representaram $65 \%$ do orçamento da Standard. O estúdio completo de gravações, montado no escritório da Rua do Ouvidor, tirou a paz dos vizinhos com a produção de jingles e spots. A agência comprava espaços de tempo e irradiava suas transmissões diretamente para as emissoras de rádio. Famosos artistas, como o popular cantor Francisco Alves, recebiam cachês para participar dos programas. O êxito da agência trouxe novos clientes, como a grande cadeia de lojas de varejo Modas A Exposição-Clipper, a companhia aérea Vasp, o instituto de medicamentos Fontoura, a fábrica de pneus Goodyear, o medicamento Vick Vaporub (na época Vap-O-Rub) e a joalheria Casa Castro. Em 1939, o ingresso da conta da Shell trouxe o respaldo empresarial, que atraiu clientes de peso como o Banco Moreira Salles e o Banco Lowndes (Reis, 1990).

A Standard continuou explorando o potencial do rádio e produziu a primeira novela radiofônica do Brasil. Em busca da felicidade foi divida em capítulos veiculados três vezes por semana. O sucesso foi arrebatador e fez com que a produção se estendesse por dois anos (de 1941 a 1943) e expandisse negócios e oportunidades artísticas. Mais de meio milhão de cartas dos ouvintes chegaram à Rádio Nacional do Rio de Janeiro. A radionovela do cubano Leandro Blanco, adaptada por Gilberto Martins, foi um patrocínio do creme dental 
Colgate, e contou com atores como Brandão Filho, Rodolfo Mayer e Zezé Fonseca. A constância da radionovela resgatou a magia dos folhetins impressos e começou a desenvolver nos brasileiros um hábito de consumo característico, o de acompanhar a dramaturgia de perto, capítulo após capítulo, através dos meios eletrônicos. Nunca mais perdemos esse costume. Diniz (2009) coloca que o sucesso da radionovela foi imediato e povoou o imaginário do público brasileiro por pelo menos duas décadas. Alguns fatores contribuíram para a popularização do gênero, como a utilização de elementos cotidianos na construção das histórias e a facilidade de acesso dos não letrados (Diniz, 2009).

Além de um promissor modelo de consumo, a radionovela trouxe identificação da população com o rádio como um meio ativo nas experiências sociais. O veículo passou a fazer parte do cotidiano, aflorando emoções, conversas e discussões sobre a temática das obras. Essa empatia com o formato transformou os ouvintes em compradores em potencial (Diniz, 2009). A Standard também determinava os dias e horários de veiculação: segundas, quartas e sextas-feiras, às 10h30min. A publicidade assume papel central como a grande organizadora da programação e dos modelos administrativos para o universo da comunicação.

A agência também produziu os populares programas infantis $O$ vingador e Aventuras de Tarzan, ambos oferecidos pelos Sabonetes Palmolive. O vingador atraiu a audiência de milhares de jovens e adultos que não perdiam seus capítulos diários em seis das mais importantes estações brasileiras: Rádio Tupi do Rio; Rádio Tupi de São Paulo; Rádio Cultura de São Paulo; Rádio Guarani de Belo Horizonte; Rádio Farroupilha de Porto Alegre e Rádio Clube de Pernambuco. Os episódios de 15 minutos eram ouvidos em pesados aparelhos de válvulas, situados nas salas de estar, onde as famílias se reuniam para dar vazão às suas imaginações. O autor da série era o publicitário Péricles do Amaral, que mais tarde também criou os seriados Capitão Atlas e Aventuras do Anjo. O programa Aventuras de Tarzan não ficou atrás e teve seu clube de admiradores, chamado de "Amigos de Tarzan". Para se tornar sócio e receber o distintivo do clube era preciso enviar uma caixa vazia da pasta dental Colgate com nome e endereço para a rádio que apresentava o programa (Cardoso, 1998). O entusiasmo da ColgatePalmolive pelo rádio fez com que a agência montasse um estúdio no Rio e outro em São Paulo. A essa altura, a agência somava números impressionantes para a época: quase 200 contas, uma equipe de 203 funcionários, dois escritórios 
nacionais - Rio e São Paulo - e quatro internacionais - Buenos Aires, Santiago, Nova Iorque e Toronto (Abreu; Paula, 2007).

O triunfo contava com a rigidez do líder Cícero Leuenroth, que colocou a Standard entre as três maiores agências de publicidade do Brasil, ao lado das multinacionais JWT e McCann-Erickson. Leuenroth era respeitado e ao mesmo tempo temido, sua opinião repercutia em toda a classe profissional. Segundo Bourdieu (1983 [1976]), o capital cultural se estabelece como um recurso de poder. Prestígio, contatos e bens financeiros vão moldar a percepção coletiva de determinadas aptidões, gostos, informações, status de um membro em um campo. As disposições internalizadas pela comunidade determinam as classificações, hierarquias e condicionamentos sociais.

O publicitário achava que o cliente deveria escolher a agência pela análise dos serviços prestados, afinal, para ele, “(...) fazer anúncios qualquer um pode fazer. Responsabilizar-se pelo desenvolvimento de uma conta, é outra história. Envolve um complexo de conhecimentos que só uma equipe pode ter." (RABELO, 1956: 21). Essa visão o levava a defender a divulgação das próprias agências em si, para criar prestígio para os negócios e propagar a extensão de serviços que as empresas podem prestar. Até meados dos anos 1950 era possível dizer que mais de $50 \%$ dos anunciantes ainda não conheciam de fato os serviços de uma agência. Diante dessa necessidade de autopromoção, um Departamento de Assuntos Econômicos foi criado na Standard. O setor desenvolveu estudos sobre as condições do Brasil, com dados e informações de mercado, a fim de orientar a clientela sobre possíveis oscilações e apresentar a variedade de profissionais que formava a equipe da agência (Rabelo, 1956).

Além da primazia no rádio, a agência transformou definitivamente o calendário nacional ao introduzir na sociedade brasileira o Dia das Mães e o Dia dos Namorados, como datas comerciais para alavancar vendas. O primeiro Dia das Mães aconteceu no segundo domingo de maio de 1948 e o primeiro Dia dos Namorados em 12 de junho de 1949 (Reis, 1990). Como o custo de produção da primeira campanha institucional era bastante alto, foi formado um conglomerado - pool, na linguagem empresarial - com o apoio da Associação Comercial e do Sindicato dos Lojistas. O financiamento inicial veio das redes de varejo Moda A Exposição-Clipper e Mappin, que cobriram $10 \%$ dos gastos. A Federação do Comércio de São Paulo e o Serviço Social do Comércio complementaram o apoio 
financeiro. Apesar das dificuldades de produção, a campanha foi um sucesso e as vendas no varejo alcançaram marcas tão altas quanto as de Natal. Estimulada pela conquista, a agência lançou o Dia dos Namorados no ano seguinte, com resultados similares. Quatro anos depois, o jornal $O$ Globo idealiza o Dia dos Pais. A primeira comemoração se deu em 16 de agosto de 1953, mesmo dia de São Joaquim, pai de Nossa Senhora. Nos anos seguintes, a data passou a ser festejada no segundo domingo de agosto, em paridade ao Dia das Mães. Estes marcos anuais passaram a ser os mais importantes para o comércio brasileiro depois do $\mathrm{Natal}^{57}$.

A incorporação dessas celebrações ao nosso calendário é uma amostra de como o consumo é um fenômeno capaz de modificar subjetividades e estilos de vida de uma sociedade. Datas mágicas são criadas a fim de transformar o ato da compra em um rito que envolve, de alguma forma, a esfera do sagrado (Rocha et al, 2013b). Emoções, festejos, planejamentos familiares são acionados através da narrativa publicitária que incentiva a compra de presentes para pais, mães e namorados, alterando suas rotinas. $\mathrm{O}$ presente se torna um símbolo de afeto. Logo, o tamanho ou o volume de presentes doados ao ente querido representam maior ou menor quantidade de afeto. Da mesma forma, a ausência destes artefatos materiais simbolizam esquecimento, desapego, falta de dedicação, descompromisso. O presente passa a ser uma obrigação social e uma projeção de como se quer ser percebido em uma determinada cultura. Marcel Mauss (2003 [1925]) mostra como a troca de objetos entre coletividades constrói laços de relacionamentos duradouros, a dádiva estimula fortes alianças, hospitalidade e proteção recíprocas. O estudo de Mauss sugere que amigos devem sempre trocar presentes, com o propósito de continuarem amigos, assim como o presente deve sempre ser retribuído, a fim de manter a relação. Com a persuasão da narrativa publicitária e o peso do consumo em nossa estrutura social, o presente se torna uma das maiores obrigações morais, assumindo um caráter imposto e interessado, mesmo sob o disfarce da "voluntariedade". Dar e receber são ações de troca simbólica que expressam fortes conexões subjetivas entre os envolvidos. Aceitar algo é receber a alma, a essência do outro e não se pode rejeitar uma doação. As

\footnotetext{
${ }^{57}$ Fonte: www.memoria.oglobo.globo.com
} 
relações com as coisas trocadas estabelecem elos permanentes que juntam muitas coletividades (Mauss, 2003 [1925]).

Paralelo ao sucesso da Standard, outra agência também contribuía significativamente para a prosperidade do negócio da propaganda no país naqueles idos dos anos 1930. A McCann Erickson instalou-se no Rio de Janeiro em 1935. A vaga de gerente do escritório brasileiro foi conquistada por Armando de Moraes Sarmento, de apenas 22 anos, que acumulava experiência de redação adquirida na Ayer e na $J W T$, além de um inglês fluente. Sarmento galgou os mais altos cargos da empresa no mundo. O brasileiro conseguiu em poucos anos a inédita façanha de presidir a McCann Erickson International e a McCann Erickson dos Estados Unidos, em 1959 (Abreu; Paula, 2007).

A agência norte-americana foi resultado de uma fusão entre duas agências pioneiras, a The HK McCann Company, de Harrison McCann, inaugurada em 1912 e a Erickson Company, de Alfred Erickson, fundada em 1902. Depois de abrir a matriz em Nova Iorque, a empresa rapidamente se expandiu para todo o território americano e lançou sua trajetória internacional com agências no Canadá, em 1915, na Europa, em 1927, na América Latina, em 1935, na Austrália, em 1959, e na Ásia, em 1960. Como veremos adiante, hoje a McCann é formada por inúmeras empresas associadas que a transformaram em um grande "player" da comunicação global. No mundo corporativo, a expressão "player de mercado" se refere a empresas que dominam, por sua produção, patrimônio, desempenho e retorno financeiro, a sua área de atuação e o mercado em que estão inseridas. $\mathrm{O}$ McCann Worldgroup é presidido por Luca Lindner e tem como Chairman e CEO, Harris Diamond. O McCann Worldgroup é uma companhia formada pela McCann Erickson (publicidade), MRM (marketing digital, gestão de relacionamento), Momentum (marketing de eventos, promoções), McCann Health (profissional da saúde, comunicação direta ao consumidor), CRAFT (produção e adaptação global), UM (gestão de mídia), Weber Shandwick (relações públicas), e Future Brand (consultoria/design) ${ }^{58}$. No Brasil, fazem parte do grupo a WMcCann, resultado da união com o publicitário Washington Olivetto em 2010, a Momentum, a S2Publicom, a Future Brand, a McCann Health Preview e a E/OU MRM. Segundo o Ibope, a WMcCann ocupa o terceiro lugar no atual ranking das

${ }^{58}$ Fonte: www.mccann.com 
maiores agências brasileiras ${ }^{59}$.

A McCann, como é comumente chamada, chegou ao Brasil para cuidar de um único cliente: a Standard Oil Company of Brazil, mais tarde denominada Esso Brasileira de Petróleo. Renato Castelo Branco e David Augusto Monteiro foram escolhidos os primeiros redatores através de concurso. Em 1937, este último passou a gerenciar o escritório recém-aberto em São Paulo, consequência da conquista da conta da Frigidaire. A marca virou sinônimo de refrigerador elétrico no Brasil. As geladeiras ainda eram artigo de luxo nos lares brasileiros. $\mathrm{Na}$ maioria das casas, carroças entregavam barras de gelo que eram depositadas nos chamados frigoríficos, armários de madeira com paredes duplas isoladas termicamente que não eram conectadas à eletricidade. Com a campanha feita pela McCann, os refrigeradores Frigidaire se tornaram um produto conhecido e desejado pelas famílias. O mesmo aconteceu com o Flit: o produto se tornou o equivalente a "inseticida".

Em 1939, a McCann ganhou o primeiro prêmio internacional da propaganda brasileira: Menção Honrosa Especial na Feira Mundial de Nova Iorque pela campanha do óleo Saúde, da Anderson Clayton. A partir desta conquista, começa a ampliar sua atuação e incorpora nomes de destaque no mercado da publicidade, como Emil Farhatt e Ítalo Éboli (Abreu; Paula, 2007).

A agência também participou da modernização do setor radiofônico com criação de slogans e projetos marcantes que até hoje permanecem na memória de gerações. Para a popular Rádio Nacional, a McCann produziu o Repórter Esso, programa jornalístico que rapidamente se tornou o mais importante do rádio (Klöckner, 2008). Durante a II Guerra Mundial, em 1941, a Rádio Nacional queria divulgar a Guerra sob o ponto de vista dos aliados. Assim nasceu o projeto, que foi apoiado pelo presidente Getúlio Vargas e teve a orientação do Departamento de Imprensa e Propaganda, o DIP. Sob a chancela publicitária da McCann e o patrocínio da Standard Oil, a versão brasileira do americano "Your Esso Reporter" foi implantada. Os slogans "O primeiro a dar as últimas" e "Testemunha ocular da história" foram decisivos para o sucesso do programa e se tornaram marcos da transmissão radiofônica. Com um estilo sério e direto, o

\footnotetext{
59 Fonte: Ibope - dezembro 2014. Disponível em: http://www.ibope.com.br/ptbr/conhecimento/TabelasMidia/rankingdeagencias/Paginas/AGÊNCIAS---50---MAIORES--2014.aspx
} 
Repórter Esso criou um padrão inédito de qualidade ao inovar o noticiário com matérias enviadas por uma agência internacional de notícias dos Estados Unidos. Com isso, os famosos locutores Kalil Filho, Gontijo Teodoro, Luís Jatobá e Heron Domingues não se limitavam a ler as notícias recortadas de jornais impressos. Além disso, o boletim radiofônico também impôs um padrão até então inédito no Brasil: horário fixo para ir ao ar. A audiência passou a acertar seu relógio e seus afazeres cotidianos pelos horários de veiculação do programa, quatro vezes ao dia (Klöckner, 2008).

O modelo implantado pelo Repórter Esso denuncia a dominação culturalideológica dos Estados Unidos, bem como representa um dos primeiros indícios da globalização através das comunicações. Nas várias edições diárias do programa, um resumo de notícias eram apresentado em cinco minutos rigidamente cronometrados. A primeira inserção era enviada a 14 países do continente americano através de 59 estações de rádio, formando uma ampla rede mundial. Os informes da United Press International divulgavam o modo de vida americano, conhecido como American Way of Life, com ênfase em notícias de celebridades e descobertas científicas. As notícias da Europa, Ásia e África só ganhavam espaço se houvesse interesses norte-americanos envolvidos. Entre os destaques históricos está o anúncio exclusivo do suicídio de Vargas, em 1954, e a ascensão de Fidel ao poder, após vencer a Revolução Cubana, em 1959 (Klöckner, 2008). O modelo do noticiário foi copiado por diversas emissoras e em 1952 ganhou uma versão televisiva, na TV Tupi.

A Inter-Americana também desenvolveu um relevante trabalho de veiculação de notícias durante a Segunda Guerra Mundial em prol da causa aliada. Com o objetivo de esclarecer e informar a opinião pública sobre as relações entre o Brasil e os Estados Unidos, a agência organizou e dirigiu o maior e mais completo serviço de imprensa e relações públicas já montado na América Latina. O projeto levava um grande volume de informações, enviadas via postal ou telegráfica, especialmente para os jornais do interior. O patrocínio veio da American Chamber of Commerce of Brazil e do Coordinator's Office of American Affairs (Abreu; Paula, 2007).

Os desdobramentos do conflito internacional não prejudicaram o crescimento interno da McCann. Na década de 1940, a sucursal brasileira não parava de impressionar toda a organização mundial. Com a estrutura montada 
aqui, a filial brasileira conquistou contas que a matriz em Nova Iorque sonhava há muito tempo. Nada menos do que Coca-Cola, General Motors, American Home, Nestlé e Goodyear passaram a fazer parte da cartela de clientes da agência (Abreu; Paula: 2007).

Para apresentar o refrigerante de cola aos brasileiros, a empresa utilizou novamente a mídia mais popular do período, o rádio. O programa "Um milhão de melodias" foi a principal peça promocional do lançamento da Coca-Cola. Dirigido por Emil Farhat e veiculado na Rádio Nacional, o musical fez sucesso desde o primeiro dia. Os arranjos e a direção dos 80 músicos que compunham uma orquestra ficaram a cargo de Radamés Gnatalli. Haroldo Barbosa, que era discotecário na Rádio Nacional, selecionava as músicas nacionais e internacionais e Paulo Tapajós era o diretor artístico (Reis, 1990). O programa investiu na música popular brasileira, dando oportunidades a artistas de vários gêneros, assim como representou mais um canal da autoridade cultural norte-americana ao veicular clássicos da música dos Estados Unidos e popularizar ritmos que até então só eram conhecidos através dos filmes. Para a Coca-Cola também foram criados grandes outdoors, que precisavam de cola especial para resistir às tempestades de verão (Abreu; Paula, 2007).

Os novos formatos radiofônicos idealizados pelas agências só foram possíveis com a coparticipação e adaptação de atores sociais de outras áreas do conhecimento. Músicos, diretores artísticos, cantores, por exemplo, passam a ser inseridos no universo da propaganda e a colaborar com sua produção de acordo com as necessidades de cada programa ou anúncio. Uma série de ajustamentos foram normatizados para condicionar esses profissionais a uma rede de relações na qual sua ocupação seria exercida. No caso de um músico foi preciso adaptá-lo às ferramentas e tecnologias do rádio e do processo de produção publicitário, fazê-lo compor para os tempos determinados e adequar arranjos conforme as orientações dos diretores da agência. O mundo social da música se incorpora e se ajusta ao mundo social da publicidade para a fabricação de um novo acontecimento social. Cada fase do processo solicitou uma nova explicação, um novo ensinamento, para que o todo pudesse ser materializado (Becker, 1977, 1986). Em geral, essa explicação é coordenada pelo mundo social que exerce liderança no jogo de forças de um sistema. As identidades sociais combinam competências e formas de cooperação de suas habilidades, dando prioridade aos 
novos saberes da organização. Becker (1977, 1977a) leva em conta os comportamentos que se desenvolvem a partir de uma sequência ordenada de ações complementares. Para existir uma cultura é preciso que haja um grupo formado por indivíduos que desenvolvem um conjunto de significados partilhados. Nesse sentido, para uma realização ser efetivada, cada explicação é importante para a compreensão do processo final, sobretudo quando diferentes mundos sociais se vinculam (Becker, 1977). Além disso, os novos meios de comunicação e suas distintas etapas de produção e materiais de execução fazem surgir novas funções que irão compor e ampliar o campo da publicidade. Interesses comuns ligados por uma rede de comunicação podem trazer adaptações a um mundo social (Becker, 1977). O setor publicitário é então formado por um conjunto de muitas especializações, categorias, profissões de outras áreas que são aglutinadas e adequadas aos seus saberes técnicos e práticos, compondo identidades híbridas.

A atuação da McCann no Brasil esteve sempre focada na introdução de novas metodologias de trabalho, trazendo modelos pioneiros para o campo, sobretudo na área de Mídia. Suas estratégias contribuíram para a organização do mundo profissional da publicidade como um todo, e serviram de espelho para outras empresas. A utilização de pesquisas próprias e do Ibope deram mais credibilidade à escolha dos veículos pelos clientes. Rádio, jornal, revista e outdoor eram analisados minuciosamente para melhor aplicação de verbas. Em 1953, a agência instalou os primeiros estudos de análise de audiência em rádio, com o "Program Analyser", um aparelho montado pelo Departamento de Pesquisas para analisar programas de rádio e, mais tarde, de televisão. Além disso, a programação radiofônica da agência era examinada por uma comissão de 350 pessoas, de várias classes sociais, que davam opiniões para eliminar os pontos fracos. Com o chamado "tráfego de leitura de anúncios", a McCann estudava permanentemente quais anúncios eram mais lidos na revista ilustrada $O$ Cruzeiro, a mais importante da época. Gráficos ainda registravam a venda diária de jornais do Rio e de São Paulo (Rabelo, 1956). As pesquisas faziam com que a agência seguisse de forma segura na elaboração das propagandas e ajudavam a saber se as campanhas tinham atingido seus objetivos, e foram hábeis no propósito de deixar no consumidor uma impressão que pudesse ser lembrada no futuro. Conforme o conhecimento do campo é aprofundado, novos atores sociais entram em cena, com novos papéis, atribuições, competências, demandas. A cadeia colaborativa do 
processo produtivo expande suas ramificações e partilhas de sentidos (Becker, 1977). O foco de interesse de Becker (1977) encontra-se mais na relação de cooperação entre os indivíduos do que nas obras que realizam. Para o sociólogo, as redes de interação são fundamentais na construção de um mundo social. $\mathrm{O}$ conhecimento compartilhado das tecnologias e etapas necessárias à realização de um trabalho produz os tipos de obras pelas quais um mundo é validado.

As condições econômicas da produção e do mercado também estavam entre as preocupações da Inter-Americana, que montou o primeiro Departamento de Estudos Econômicos e Pesquisa de Mercado do Brasil, sob a chefia do economista Omer Mont'Alegre. Os planos de vendas dos clientes passaram a ser estruturados de acordo com as conclusões destas pesquisas de mercado (Reis, 1990). No início da década de 1950, a agência enviou um de seus economistas à África para estudar as possibilidades de produção do continente, a fim de conhecer até onde poderia ir a efetiva concorrência comercial entre os artigos de exportação da África e do Brasil (Rabelo, 1956). Estas ações destacam um profissionalismo crescente das agências no mercado.

Em 1951, a McCann se transforma em sociedade anônima, sob a presidência de Armando de Moares Sarmento. As ações bem-sucedidas do grupo fizeram com que o escritório de São Paulo tivesse o maior faturamento do Brasil neste período (Rabelo, 1956). O padrão de excelência era a marca da agência, que procurava integrar todos os elementos da propaganda. Vendas, comércio, relações públicas e orientação de negócios estavam articulados para otimizar a prestação de serviços. Neste sentido, podemos dizer que a McCann contribuía para delinear as convenções do campo da publicidade no Brasil de acordo com os preceitos teóricos de Howard Becker (1977). Através da interligação de seus elementos produtivos e o considerável crescimento vertical, a agência serviu de modelo ao mercado, tendo seus padrões copiados por outras empresas, e estabelecendo assim normas de conduta e ação para a operacionalização do negócio da publicidade. Para o presidente Armando Sarmento, o coração da agência dependia da orientação dada a todos os departamentos - Arte, Redação, Promoção de Vendas, Pesquisas, entre outros. Este foi o traço distintivo da McCann em relação às demais. Sua filosofia corporativa colocou no mesmo patamar os problemas ligados à atividade comercial e os problemas do plano das ideias, sendo assim, a integração e os elos cooperativos entre os diferentes setores foram determinantes 
para o bom funcionamento do negócio. Sarmento explicou a Genival Rabelo (1956) como a agência procedia internamente na aquisição de uma conta:

Depois da "carta-acordo" firmada com o novo cliente, o contato elabora as "instruções básicas para o preparo do plano". O estudo é submetido à Comissão Consultiva de Planos, que o aprova ou reforma, encaminhando em seguida os pedidos de trabalho para os departamentos. Concluída a tarefa destes, volta o plano à Comissão Consultiva, que desta vez se compõe dos profissionais da agência que não se ocupam da conta. Há então, os debates, funcionando os membros da Comissão como "advogados do diabo". Se finalmente o plano receber a aprovação total da Comissão Consultiva será apresentado ao cliente. (RABELO, 1956: 51)

Após essas etapas intrínsecas, a apresentação da proposta deveria ser muito bem planejada para a conquista de uma conta. A exposição final também precisaria contar com o entusiasmo e convicção da equipe. Desta forma, todo um arsenal de gráficos, mapas e desenhos caricatos poderiam ser usados, a fim de facilitar a compreensão do cliente, as razões da campanha, seus objetivos e expectativas (Rabelo, 1956).

Com a aprovação da ação promocional a agência pode partir para a materialização em um veículo de comunicação ou em vários, dependendo da comunicação idealizada. Em linhas gerais podemos dividir o passo a passo para a execução das campanhas em cinco etapas articuladas, conforme a descrição de Armando Sarmento para a revista $P N$ (Rabelo, 1956). Tudo começa na chamada "fase de planejamento", em que se estuda o tamanho dos anúncios, a seleção dos veículos, a frequência da divulgação. Neste momento, o setor de Mídia fornece informações sobre o valor do veículo, tipo de leitor, classe, sexo etc. Em seguida, temos a "fase de orçamento", em que se avalia o custo do espaço em cada veículo programado e o orçamento para elaborar a campanha planejada. Na sequência, a "fase de programação" irá utilizar os estudos de Mídia para obter informações sobre o melhor rendimento dos anúncios nos jornais e revistas selecionadas, por exemplo. Os detalhes da programação variam de acordo com o produto em questão, circulação e volume de publicidade. Partimos então para a "fase de execução", quando são emitidas as autorizações para os veículos, de acordo com a programação. E, finalmente, a "fase de expedição", em que é feita a transmissão do trabalho final - clichês, estéreos - e são conseguidas as autorizações para a veiculação do anúncio nos veículos programados (Rabelo, 1956). 
O sucesso da McCann, como importante estruturadora do mundo da publicidade no Brasil, estimulava a concorrência, que buscava profissionalismo e qualidade para um mercado que ficava cada vez mais competitivo. A JWT também desempenhou papel decisivo na organização do campo no país, sobretudo após a chegada do presidente Robert Merrick nos anos 1940, vindo de Nova Iorque. Neste período, a JWT conquistou a conta internacional da Ford, que até então era uma das principais da N.W.Ayer. A agência aprimorou fórmulas de planejamento e gerenciamento, formulou campanhas memoráveis e ampliou o quadro de funcionários com nomes que fizeram história na propaganda, como Roberto Dualibi, Francesc Petit, José Zaragosa, Eric Nice, Renato Castelo Branco, Caio Domingues, Ricardo Ramos, entre outros (Reis, 1990).

No final da década de 1940, a JWT se viu diante de um grande desafio: a chamada Lei de Licenciamento. Na prática, foi uma medida intervencionista do governo, a fim de dificultar as importações. Com a venda de matérias-primas para os a países aliados, o Brasil tinha acumulado muitas reservas de moeda estrangeira durante os anos da Segunda Guerra Mundial. Ao término do conflito, viramos um grande mercado consumidor dos produtos americanos, e começamos a importar em grande quantidade a preços altos. Em pouco tempo nosso acúmulo cambial esvaeceu. A inflação atingiu altos níveis, o crédito cessou e a balança comercial ficou negativa. A Lei de Licenciamento foi decretada com o objetivo de conter os fornecedores internacionais. O movimento levou a uma industrialização com aumento da produção para o mercado interno, já que nossa moeda, o Cruzeiro, apresentava alta cotação no exterior, o que desestimulava exportações. O impacto da legislação foi excepcional para o crescimento do país. O número de empregos aumentou consideravelmente diante das novas fábricas, que não paravam de ser montadas e planejadas. No período de 1945-1951 vivemos um crescimento econômico de $6 \%$ ao ano (Martins Filho, 2011).

Outro destaque do mercado deste período foi a reabertura da Lintas em 1937, com a importação do Diretor de Arte inglês James Abercrombie e a contratação do radialista e redator Rodolfo Lima Martensen. A Lintas rapidamente ganhou evidência no setor, principalmente por sua performance no rádio e nas pesquisas de opinião e mercado. A agência montou um departamento completo de produção de programas radiofônicos, sobretudo novelas, que operava na contratação de atores e escritores, ensaios, gravação de capítulos e distribuição 
dos conteúdos por todo o Brasil. Este setor, responsável por $75 \%$ das verbas da empresa, trouxe a público nomes como Maria Augusta Barbosa Mattos, Synésio Ascêncio e José Bonifácio de Oliveira Sobrinho (Boni), que foi vice-presidente da Rede Globo de Televisão (Ramos, 1985 [1970]).

A Lintas dinamizou as pesquisas de opinião pública, antecipando-se aos institutos especializados, que mais tarde iriam dominar este fragmento de mercado. O psicólogo Alex Mitchell, do Institute of Human Relations, foi contratado pela matriz londrina para desenvolver uma metodologia de coleta rápida e eficiente da opinião popular. Surgem as "discussões em grupo", que na época receberam o nome de Lintests. O método, trazido ao Brasil em 1939, se popularizou em todo o mundo e até hoje - geralmente com o nome de focus group - é utilizado como fonte de pesquisa. (Abreu; Paula, 2007). A técnica faz parte de uma pesquisa de mercado qualitativa, na qual ocorre a discussão moderada entre um número pequeno de participantes. Os debates são coordenados por um moderador, que condiciona a sessão e facilita a interação entre os envolvidos (Luppeti, 2009).

Rodolfo Lima Martensen assume o comando da Lintas no Brasil, em 1943. Martensen foi um dos nomes mais importantes da história de nossa publicidade, tendo fundado a Escola de Propaganda do Museu de Arte de São Paulo, em 1951. Contribuiu significativamente para o desenvolvimento de uma linguagem nacional para a venda de produtos, o que sempre garantiu postos de liderança para a agência no mercado. Em 1947, depois de um estágio de 3 meses na Inglaterra, representou o Brasil no I Congresso Internacional de Propaganda, em Paris. Logo depois, participou do lançamento do primeiro sabão em pó comercializado no país, Rinso, o "que lava melhor e mais barato do que qualquer outro", conforme o slogan do anúncio publicado na Revista do Globo, em 1956: 


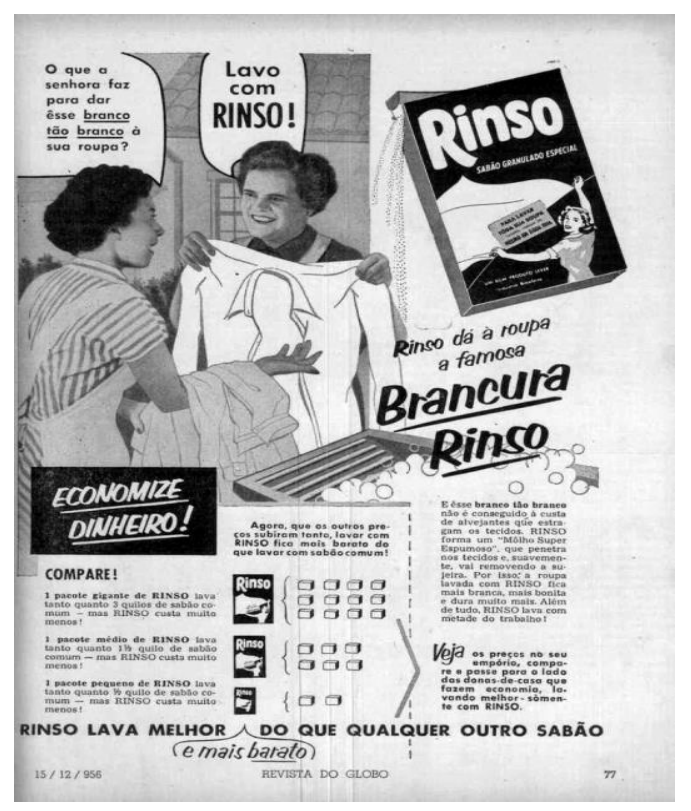

Em 1973, quando Martensen se aposentou, a agência tinha um faturamento que lhe assegurava o $4^{\circ}$ lugar em importância no mundo (Abreu; Paula, 2007). O presidente foi o responsável por instituir o que ele próprio definia como "espírito Lintas", que valorizava um estilo nacional de trabalho. Em depoimento a Fernando Reis (1990), enfatiza:

O nosso objetivo era sempre produzir propaganda com elementos locais. Nós acreditávamos que é o homem do país quem melhor conhece o elemento a ser atingido pela propaganda. Então, de forma ideal, você deveria ter uma agência totalmente nacional em cada país. (...) Não tínhamos outra coisa a fazer senão ser autênticos. Isso do ponto de vista técnico. Do ponto de vista pessoal, isto é, dentro da preocupação com o indivíduo dentro da agência, procuramos dar à Lintas um ambiente doméstico, um ambiente em que o sujeito se sentisse bem. (REIS, 1990: 325)

A Grant Advertising Publicidade também incrementou o progressivo negócio da propaganda brasileira. A agência norte-americana instalou-se no Rio de Janeiro em 1939, e atuou por 36 anos no mercado nacional, sempre nas mais elevadas posições no ranking das agências. Os primeiros anos da empresa foram presididos por Robert E. Cole, que mais tarde dirigiu a McCann. Em 1958, a matriz do Rio é transferida para São Paulo (Reis, 1990). A Grant atendeu sozinha, por muitos anos, todas as marcas de cigarros da Souza Cruz e de sua subsidiária Castellões. As vultuosas contas da General Electric, General Motors, Johnson \& 
Johnson, Sherwin-Williams, Grapete, Firestone, Pan Am e Panair do Brasil colocaram a Grant entre as 100 principais agências do eixo Rio-São Paulo em fins da década de 1940 (Abreu; Paula, 2007).

Record Propaganda, Voga Publicidade, Poyares, Sem Rival foram algumas das agências de médio porte que ajudaram a ramificar o campo da publicidade nacional naqueles idos de 1940 (Reis, 1990). A formação dessas empresas menores demonstram que o segmento já apresenta bases organizadas e reconhecidas na esfera social, a ponto de atrair outros agentes sociais para o setor. O alargamento do campo não reflete apenas a prosperidade financeira dos negócios, como também espelha a maturidade e o respeito social alcançados através das convenções e práticas instituídas pelas grandes agências.

Em um ambiente atravessado pelas agências internacionais, surge uma empresa genuinamente brasileira, que procurou instalar-se em todo o território nacional. Um ano depois do fim da Segunda Guerra Mundial, em 1946, a Empresa de Publicidade Norton Ltda. inicia suas atividades em São Paulo. Fundada por Geraldo Alonso, antigo redator de anúncios dos Diários Associados, de Assis Chateaubriand, e seus irmãos, José de Mingo e José Ary Alonso, a Norton teve como primeiro cliente a incorporadora Serva Ribeiro, que solicitou de imediato um anúncio imobiliário na Avenida Angélica, ponto nobre de São Paulo. No ano seguinte, em 1947, a empresa já anexava duas pequenas agências, a Ímpar, de Helio Silveira da Mota, e a Sirius, de Nilo Lisboa Ramos (Reis, 1990).

Com a campanha para veículos impressos dos relógios Marvin, do grupo francês Tic (Técnica Indústria e Comércio), a agência fatura o seu primeiro prêmio: a publicação dos anúncios com destaque no Anuário de Publicidade, de 1947, uma das conquistas mais prestigiadas da época. Um ano depois, abre filial no Rio de Janeiro, então Distrito Federal. Em 1955, foi responsável pelo lançamento da máquina de lavar roupa automática Bendix, uma das campanhas de maior sucesso do Brasil. O bordão "Não jogue no tanque seus encantos de mulher" teve enorme repercussão nacional (Reis, 1990: 337). Nesta época, a Norton já estava entre as maiores agências em funcionamento no Brasil, com uma admirável carteira de clientes, entre os quais estavam a Nestlé, o magazine Mesbla, General Electric, a empresa de louças sanitárias Ideal Standard, Perfumes Dana, Bendix Home Appliances do Brasil, Serva Ribeiro e a organização imobiliária Inimá Barra (Abreu; Paula, 2007). 
As agências de propaganda se colocavam como instrumentos vitais para organizar e potencializar os lucros da crescente produção industrial brasileira. $\mathrm{O}$ fortalecimento de um campo está atrelado ao acúmulo de capital econômico, um dos mais importantes de nossa cultura, segundo Bourdieu (1983 [1976]). Ordenar a produção industrial é instalar-se nas bases econômicas de um país, ajudar a fabricar riquezas e ter preponderância na disposição dos agentes e instituições situados no espaço social.

$\mathrm{Na}$ estrutura capitalista, sempre que temos um aumento de produção, também surgem as necessidades de divulgação, propagação e distribuição. Muitas agências se tornaram consultoras de marketing, ajudando a recrutar profissionais de vendas, promoção e equipes de propaganda. Para atender seus clientes, as empresas montaram verdadeiras escolas de propaganda e vendas, dedicadas à seleção e treinamento de profissionais para atuar na indústria. Segundo Fernando Reis (1990), este foi o embrião do curso de Administração de Negócios, criado na Universidade de São Paulo. Virgil Reed, da JWT de Nova Iorque, veio ao Brasil implementar o projeto. O gerente Robert Merrick importou talentos do marketing internacional para treinar os brasileiros, inserir técnicas de pesquisas e programas de treinamento de pessoal. Em depoimento à Revista Propaganda em junho de 1979, Merrick ressalta o papel das agências para a transformação econômica do Brasil:

Orgulho-me em dizer que quando deixei o Brasil, em 1961, estes especialistas tinham realizado sua missão e retornado aos seus países e a nossa organização era $100 \%$ brasileira. (...) As agências merecem o reconhecimento público pelo importante papel que desempenharam na criação do império industrial do Brasil. (REIS, 1990: 314)

Em 1952, a $J W T$ faturou $30 \%$ a mais que no ano anterior, cerca de 125 milhões de cruzeiros $^{60}$, e passou a selecionar os clientes. Há dez anos, em 1942, esses números não ultrapassavam a casa dos 8 milhões de cruzeiros. A McCannErickson conquistou o dobro de 1950 e onze vezes mais do que em 1945 (Rabelo, 1956).

A insegurança e as incertezas do Pós-Guerra tinham dado lugar a um

\footnotetext{
${ }^{60} \mathrm{O}$ valor corresponde a cerca de 500 milhões de reais, de acordo com a tabela de conversões do jornal $O$ Estado de S. Paulo. Disponível em: http://acervo.estadao.com.br
} 
cenário de esperança e prosperidade que há muito tempo não se via no país. Os anos que se seguiram ao segundo esforço bélico mundial foram marcados pela tentativa de superação das limitações, principalmente em relação às dificuldades econômicas. O início das operações da Companhia Siderúrgica Nacional (CSN), em Volta Redonda, em 1946, foram os primeiros passos da indústria de base. A promessa de rápida recuperação industrial animou o país (Bastos; Fonseca, 2012). Novos equipamentos gráficos começam a chegar para fomentar a produção de anúncios. A propaganda vivia um momento de virada com a normalização das trocas comerciais.

No plano político, o ditador deposto Getúlio Vargas voltava eleito presidente, depois de uma esmagadora vitória nas urnas sobre seus dois opositores, Eduardo Gomes e Cristiano Machado, mostrando que a velha máquina política em torno do populismo ainda era eficaz. Entoando a defesa dos direitos à liberdade e à vida, Vargas queria se livrar da figura de ditador neste novo governo democrático que tem início em 31 de janeiro de 1951. O mandato foi marcado por um projeto desenvolvimentista baseado na forte presença do Estado como regulador e empreendedor de atividades econômicas. A intervenção estatal pretendia estimular ainda mais a industrialização e a modernização do Brasil (Bastos; Fonseca, 2012).

A parceria do rádio com a publicidade ajudava a trazer um sentido de unidade ao país. Falávamos a mesma língua, consumíamos os mesmos produtos e ouvíamos as mesmas notícias e anúncios de uma ponta à outra do território nacional. Assim, todos sabiam que "o mais perfeito fixador de cabelos" era o Brylcreem, que para a tosse Phymatosan "dá o alívio que lhe faz bem", que "a vida com saúde é outra coisa" graças ao Elixir de Inhame Goulart e que CocaCola era uma "pausa que refresca" (Reis, 1990: 336). A familiaridade com as mensagens estimulava a construção de identidades culturais, a partir das referências trazidas pelos meios de comunicação. A publicidade produz conteúdos que ditam as escolhas de consumo das famílias e indivíduos, projetando moldes de comportamento e estilos de vida em cada tempo histórico. Neste sentido, podemos ponderar que a representação da vida cotidiana moderna é mantida pelas influências sociais da comunicação e da interação entre os sujeitos (Kellner, 2001). A mídia se põe como um canal determinante para as trocas sociais, ao atuar como um dispositivo operador do processo de tradução, interpretação e 
combinação das representações, transformando dados não familiares em próximos, acessíveis e sintetizando a tendência de acomodar conceitos em modelos tangíveis. Como sugere Douglas Kellner (2001), a mídia fabrica uma cultura própria, que modela as concepções políticas e comportamentais, oferecendo material para a elaboração de identidades e produções de sentido para a vida social.

A publicidade da época também foi marcada pelo aparecimento de grandes produtores de jingles, as mensagens musicadas com um refrão simples e curto. Entre eles: Victor Dagô, Miguel Gustavo, Arquimedes Messina, Heitor Carrilo, Geraldo Mendonça (Reis, 1990). Novamente, outros atores sociais despontam no campo, contribuindo com inovações marginais que desviam as convenções. Os sistemas padronizados têm suas rotinas alteradas, com a introdução de agentes e funções até então não utilizadas ou desconhecidas (Becker, 1977). As capacidades formais e técnicas de um mundo precisam adaptar suas limitações organizacionais, para que produtores e também consumidores possam lidar com a nova representação acionada por um mundo social. Esse movimento constante atualiza e ajuda a manter o interesse dos receptores por uma área que se empenha na modernização. Na maioria das vezes, tais alterações, contudo, são periféricas e facilmente agregadas à rotina de fabricação do campo (Becker, 1977).

\section{4 - $O$ triunfo das agências}

À medida que o parque industrial brasileiro se desenvolvia, também crescia o número de grandes empresas que recorriam à propaganda para solucionar seus problemas de vendas. Na década de 1950, tínhamos mais de cem agências em funcionamento no Rio e em São Paulo. As cinco de maior faturamento foram destacadas em uma tentativa pioneira de classificação feita pelo Anuário de Publicidade - PN, de 1949/1950. A liderança era ocupada pela $J W T$, com uma receita de aproximadamente 50 milhões de Cruzeiros. Na segunda posição vinha a Standard, com cerca de 30 milhões de Cruzeiros. Em terceiro lugar estava a McCann, com uma renda de 10 a 20 milhões de Cruzeiros. Em quarto ficavam Panam, Inter, Grant, Lintas, Record e Poyares, oscilando entre os 
5 e 10 milhões de Cruzeiros. Norton, Texas e Arco Artusi fechavam o ranking com um faturamento de 2 a 5 milhões de Cruzeiros anuais ${ }^{61}$ (Reis, 1990).

Mesmo assim, muitos dos homens de negócios do país não conheciam ou resistiam a utilizar o potencial e o significado da propaganda comercial. Diversas empresas ainda produziam seus próprios anúncios de forma amadora e sem nenhum conhecimento técnico. Mas foi justamente uma campanha bem planejada pela Inter-Americana que permitiu que as indústrias Drago saíssem da crise e recuperassem sua posição de mercado, como relembra Armando D'Almeida:

Drago, por exemplo, que vê na propaganda não uma rubrica de "despesas" mas uma salutar "inversão" de capital, inversão altamente remuneradora, pelas vendas que promove, graças à receptividade da massa brasileira à influência da propaganda bem orientada. (RABELO, 1956:42)

O nacionalismo de Vargas controlou a entrada de capital estrangeiro no país para incrementar nossa produção, mesmo aceitando a incisiva interferência norte-americana em diversos setores econômicos, políticos e culturais. A vitória dos Aliados na Segunda Guerra Mundial contra os países do Eixo consagrou a influência norte-americana por aqui (Abreu; Lattman-Weltman, 1994). A adoção do chamado Plano Lafer, organizado pelo ministro Horácio Lafer e implementado com o apoio financeiro dos Estados Unidos, tinha como intenção incentivar a indústria de base, criar novas fontes de energia e ampliar as técnicas agrícolas, visando o aumento da produção e das exportações. Sob o lema "O petróleo é nosso", a Petrobrás foi criada em 1953. No ano anterior, tivemos a inauguração do Banco Nacional de Desenvolvimento Econômico, BNDE (que só nos anos 1980 teve o "Social" agregado a seu nome) e a dominância do sistema nacional de geração de energia elétrica com a Eletrobrás. Além disso, foi elaborado um decreto que limitava em $10 \%$ a remessa de lucros às empresas estrangeiras que estavam no país (Martins Filho, 2011).

O estímulo governista ao desenvolvimento industrial e a evolução dos nossos métodos comerciais estabeleceram uma garantia de novos negócios, cada vez mais importantes para as agências. Na fase final do governo varguista, uma crise política foi desencadeada por grupos oposicionistas, com manifestações de

\footnotetext{
${ }^{61}$ Um milhão de Cruzeiros corresponde a aproximadamente cinco milhões de reais, de acordo com a tabela de conversões do jornal $O$ Estado de S. Paulo. Disponível em: http://acervo.estadao.com.br
} 
protesto e greves trabalhistas. Na imprensa, o movimento contra Getúlio era insuflado principalmente pelo jornalista Carlos Lacerda, que publicava em seu jornal Tribuna da Imprensa recorrentes artigos de denúncia de corrupção e desmandos administrativos do governo federal (Abreu; Lattman-Weltman, 1994). A tensão política culminou com o suicídio de Vargas, em agosto de 1954, e simbolizou a vitória partidária dos liberais que defendiam maior abertura ao capital estrangeiro. Os produtos importados passaram a chegar em maior volume e instigar um consumo e uma concorrência ativa entre as empresas, que não podiam mais prescindir de publicidade. Artigos brasileiros disputavam cada vez mais espaço com marcas dos Estados Unidos, como Kolynos, Frigidaire, Walt Disney, Bardhal. As europeias Nestlé, Bayer e Facit também aportaram em solo nacional (Carrascoza; Hoff, 2011b).

Vários fatores foram responsáveis pelo grande impulso da publicidade brasileira nos anos 1950 e seu posterior amadurecimento a partir da década de 1960. Outras empresas internacionais, valendo-se de novas técnicas de marketing e de vendas fortemente expandidas nos Estados Unidos depois da Segunda Guerra Mundial, vieram para o Brasil aproveitar a potente industrialização que se anunciava. Para dar ênfase às vendas foram aplicadas armas do marketing como pesquisas, propaganda e promoção (Augusto, 2013).

A aura desenvolvimentista do setor foi ainda mais estimulada pela fundação da primeira escola dedicada ao ensino da publicidade, a Escola de Propaganda de São Paulo, em 1951, por Rodolfo Lima Martensen. A empreitada rumo ao ensino da propaganda se deu em 1950, durante o I Salão Nacional de Propaganda, a convite de Pietro Maria Bardi, presidente do Museu de Arte de São Paulo, MASP (Martensen, 2001). A ideia inicial era montar um curso sobre publicidade para o Instituto de Arte Contemporânea, mantido pelo museu. Viagens aos Estados Unidos, França e Inglaterra deram o subsídio cultural ao projeto de uma escola profissionalizante, que contou com o apoio do jornalista Assis Chateaubriand, presidente dos Diários Associados, maior conglomerado de mídia da América Latina. Sob o slogan "Ensina quem faz", o projeto foi aprovado em 27 de outubro de 1951, e tinha como missão contribuir para a profissionalização do campo no país em associação ao aperfeiçoamento da prática (Martensen, 2001). A primeira turma foi formada no ano seguinte, com professores voluntários, executivos e diretores de agências. A instituição pioneira 
manteve-se no MASP até 1955, quando se mudou para endereço próprio, graças ao apoio financeiro do mercado. Em 1964, a escola foi rebatizada como Escola Superior de Propaganda de São Paulo, e em 1971 o diretor Otto Hugo Scherb alterou novamente seu nome para Escola Superior de Propaganda e Marketing (ESPM), já que havia uma necessidade mercadológica de maior investimento no ensino do marketing, pouco valorizado até então. O movimento de renovação levou Martensen e a antiga diretoria a uma renúncia coletiva. No mesmo período, a instituição ganhou o reconhecimento do Ministério da Educação e Cultura, graças ao apoio do então ministro da Fazenda Delfim Neto. Os cursos foram adaptados para quatro anos, no formato das demais graduações em Comunicação Social (Martensen, 2001).

O processo de profissionalização do jornalismo e a ampliação das possibilidades de impressão, com o aperfeiçoamento do parque gráfico nacional, também conferiram incentivo à publicidade com o nascimento de novas revistas e a possibilidade de publicação de anúncios em cores, com boas qualidades de impressão, como foi o caso da revista Manchete, nascida em 26 de abril de 1952. Fundada por Adolpho Bloch, a publicação semanal de variedades e notícias era sofisticada e rapidamente se tornou um influente veículo de comunicação. Os anúncios coloridos de página inteira contrastavam com as reportagens publicadas em preto e branco. $\mathrm{O}$ investimento na fotografia foi um dos grandes trunfos da revista, que se tornou uma referência de comportamento e estilo para os brasileiros. O carro-chefe do grupo Bloch Editores chegou a contar com a colaboração dos escritores Carlos Drummond de Andrade, Rubem Braga e Fernando Sabino (Gonçalves; Barros, 2008). As revistas Visão, Capricho e Cinelândia também viabilizaram a publicação de anúncios em cores com linguagens visuais elaboradas (Abreu; Paula, 2007). A famosa Revista do Rádio, que tinha enorme apelo por retratar exclusivamente notícias do universo artístico do rádio, cinema e teatro, incrementava seu conteúdo com mensagens publicitárias diretas, dirigidas especialmente ao público feminino (Faour, 2002). A versão brasileira da revista em quadrinhos americana $O$ Pato Donald marca o nascimento da Editora Abril em 1950, com anúncios de clientes da McCann ${ }^{62}$.

\footnotetext{
${ }^{62}$ Fonte: www.grupoabril.com.br
} 
A maioria dos periódicos do país passava por grandes reformas editoriais. O Jornal do Brasil implementou importantes mudanças gráficas e de conteúdo a partir de 1956, o que influenciou toda a imprensa brasileira. Entre as principais alterações, o que mais chamou a atenção foi o design assimétrico da primeira página e a adoção de uma coluna em formato de "L" com os anúncios (Barbosa, 2007). Os discursos da neutralidade e da objetividade ganharam força como estratégias para legitimar a própria profissão de jornalista e afastá-la da narrativa literária, panfletária ou romanceada, ainda muito praticada. O processo de modernização do jornalismo através do registro factual da sociedade invade as redações e expõe a mítica da notícia objetiva, a que informa oficialmente o cidadão sobre aquilo que acontece no mundo. A narrativa jornalística passa a reproduzir com fidelidade os fatos da realidade e o repórter é investido da função de "(...) intérprete isento e objetivo do mundo social (...)", o que auxilia o reconhecimento e a autonomia do campo (BARBOSA, 2007: 151). As novas técnicas de produção textual, inspiradas em modelos norte-americanos, contrastavam com o caráter opinativo, ou mesmo especulativo, empregado nas publicações anteriores (Goulart, 2006). O modelo do pequeno anúncio diagramado em meio às notícias era o mais comum nas páginas da imprensa diária, como podemos observar pela capa do jornal O Estado de S. Paulo, de 27 de julho de $1952^{63}$.

\footnotetext{
${ }^{63}$ Fonte: Acervo Estadão: http://acervo.estadao.com.br/pagina/\#!/19520727-23683-nac-0001-9991-not
} 


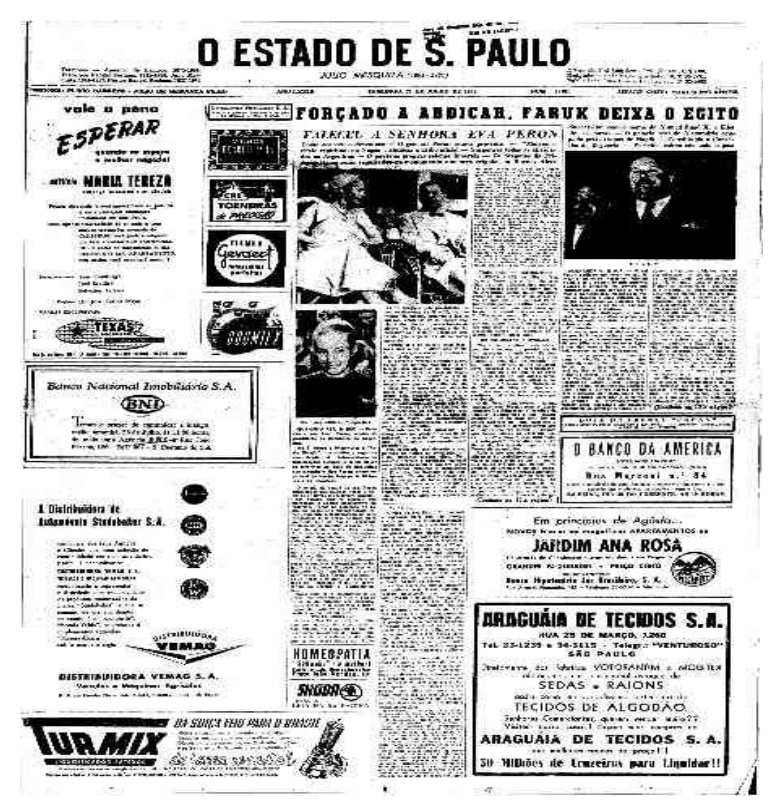

A década de 1950 também é marcada por um dos dispositivos mais emblemáticos da história da comunicação no país: a televisão. O invento marcará uma nova etapa no sistema de produção cultural do Brasil. Produtores, técnicos, distribuidores, artistas, consumidores são colocados em interação para orquestrar seus conhecimentos e seus modos convencionais de fazer as coisas, a fim de produzir - e entender - um tipo de obra que irá caracterizar esse novo mundo (Becker, 1977). Com a televisão, fica evidente a reinvenção permanente da cultura através do engajamento e troca conjunta dos agentes sociais diante de diferentes situações. O processo baseado no compartilhamento de sentidos é o caminho para coordenar a ação dos sujeitos (Becker, 1977). A televisão inaugura mais um campo de disputas e negociações dentro do universo das comunicações. Novas redes de poder, divisões de trabalho, rotinas, recursos, convenções, hierarquias, são acionadas para o surgimento de um tipo específico de produto social (Becker, 1977).

A nova tecnologia foi trazida por Assis Chateaubriand após uma viagem a Nova Iorque no final da década de 1940. Na sede da produtora de aparelhos e transmissores, RCA Victor, o empresário ficou fascinado por aquela caixa preta que projetava imagens em preto e branco e áudio irregular. Imediatamente importou o invento, a despeito das análises dos engenheiros de lá de que o Brasil não estava preparado para receber o custoso empreendimento. A consultoria não foi ouvida por Chatô, que tratou de emitir notas promissórias dos Diários Associados para garantir o negócio (Amorim, 2005). 
No dia 18 de setembro de 1950 entrava no ar a TV Tupi de São Paulo, sob o prefixo de PRF-3 TV Difusora, direto do palácio do rádio, no prédio da rádio Tupi, no bairro do Sumaré. Duzentos aparelhos foram importados dos Estados Unidos. Parte deles foi doada a personalidades influentes, empresários e políticos. Chatô mandou instalar o restante em praças públicas em pontos estratégicos da cidade de São Paulo, para que o povo conhecesse a grande novidade. O "Show na Taba" foi o grande espetáculo de inauguração, com apresentações de humor, esquetes de teatro, números musicais e quadros de dramaturgia dirigidos por Demirval Costa de Lima e Cassiano Gabus Mendes, que na época só tinha 19 anos (Lorêdo, 2000). A transmissão foi ao vivo, em meio a um grande tumulto, com câmeras quebrando e sem que se soubesse a programação do dia seguinte. Artistas como Lima Duarte, Homero Silva, Walter Foster e Lolita Rodrigues estavam presentes. Quatro meses depois, a preciosa carga desembarcava no Rio de Janeiro (Morais, 1994). A primeira emissora brasileira foi também a primeira da América Latina. O Brasil foi o quinto país do mundo a ter um serviço diário de televisão aberta, graças à ousadia intempestiva de Chateaubriand (Amorim, 2005).

Após a inauguração confusa, pouco se avançou nos primeiros anos da televisão no Brasil. A indústria nacional ainda não fabricava aparelhos transmissores, que precisavam ser importados, o que encarecia seus preços. Até o fim dos anos 1950, televisão ainda era artigo de luxo, destinado às camadas mais ricas da população. Desta forma, a programação das emissoras seguia uma linha elitista, com shows de música erudita, entrevistas, debates, teleteatros - tudo ao vivo, preto e branco, com algo em torno de quatro e seis horas diárias no ar (Lorêdo, 2000). Não havia programação simultânea em rede nacional e o número de telespectadores também não era significativo.

A televisão brasileira submeteu-se à influência do rádio, aproveitando seus profissionais e técnicos, ao contrário do modelo norte-americano, que contou com o apoio da indústria cinematográfica. A televisão promoveu "desvios" nas convenções radiofônicas, nos termos de Becker (2008 [1963]). O desvio, como vimos, é moldado por condições históricas, transformadas pelo tempo e espaço, especificadas pelas definições coletivas e relações de poder (Becker, 2008 [1963]). Aqui o desvio pode ser entendido como um conjunto de pequenas mudanças que sutilmente alteram e aperfeiçoam o sistema e as relações sociais. A partir dos padrões já dominados, das atividades habituais, dos materiais 
instalados, da atuação conjunta dos atores sociais, adaptações foram acopladas para que o sistema continuasse a funcionar, os conflitos fossem pequenos e os poderes e hierarquias preservados. A existência de convenções e rotinas préinstaladas facilitavam a criação, distribuição e uso dos recursos de um mundo social (Becker, 1977, 1977a).

$\mathrm{O}$ vínculo radiofônico não se restringiu apenas à programação. A televisão não se sustentava sozinha, contava com o apoio financeiro do rádio, até então o meio mais influente da sociedade e que abocanhava as maiores fatias do orçamento publicitário. No início, a maioria dos anunciantes e empresários desconfiava da capacidade do novo veículo de vender produtos (Amorim, 2007).

A publicidade entrou na televisão por dois caminhos, através de programas patrocinados e produzidos pelas agências e também através das "garotas propaganda". Moças jovens e bonitas demonstravam as qualidades dos produtos nos intervalos da programação. Desde geladeiras até objetos de decoração tinham seus atributos descritos ao vivo. A época é marcada por muitos improvisos, vexames e um caráter aventureiro na produção das propagandas comerciais. As "garotas propaganda" reinaram por 15 anos. As mais conhecidas foram Neyde Aparecida, Anita Taranto, Magdalenna, Wilma Rocha e Idalina de Oliveira (Lorêdo, 2000). Com esta função, a publicidade definia mais um papel social na área das comunicações e uma identidade cultural. A credibilidade dada ao setor permitia a construção de determinadas identidades na vida coletiva.

Muitos programas também levavam o nome das empresas patrocinadoras, como Grande Gincana Kibon, Repórter Esso, Espetáculos Tonelux, Concertos Matinais Mercedes-Benz, Teatro Wallita. Na maioria das vezes, as agências produziam toda a estrutura do programa e compravam os espaços na programação para divulgar seus anunciantes. Poucos eram os comerciais filmados, veiculados apenas com uma narração em off e imagens simples (Lorêdo, 2000).

Com o tempo e o crescimento na produção e fabricação nacionalizada, o preço dos televisores ficou mais acessível, emissoras se instalaram em outros estados e caminharam para uma independência financeira, diminuindo sua ligação com o rádio. Com isso, a televisão começava a ampliar sua área de atuação e atrair mais agências de publicidade e anunciantes. A facilidade de gravação e edição de imagens com a chegada do videoteipe, a partir dos anos 1960, fez com que os empresários passassem a acreditar na capacidade de comunicação do novo 
meio. No início, os profissionais não sabiam lidar com a nova tecnologia. $\mathrm{O}$ domínio veio aos poucos, após inúmeras tentativas e consecutivos erros. Funcionários de outros setores das emissoras eram constantemente promovidos a operadores de videoteipe (Amorim, 2007). A mudança contínua, gradual ou drástica, é característica de qualquer mundo social, conceitua Becker (1977). Nenhum mundo artístico consegue manter-se distante das mudanças por muito tempo. Ciclos de renovação desenvolvem-se gradualmente, enquanto outras convenções desaparecem, seja resultantes de forças externas, ou tensões intrínsecas ao campo. Com a introdução de novos materiais, funções também são implementadas. O concatenamento de agentes sociais e atividades integradas são confirmados para a materialização do produto social (Becker, 1977).

O poder de aliar imagens e áudio aos comerciais foi o impulso que o veículo precisava para deslanchar e, aos poucos, tornar-se uma mídia de peso nas comunicações. Gradativamente a televisão atrairá os melhores anunciantes, o que acabou se tornando o grande fator de decadência do rádio espetáculo (Ferraretto, 2007). É preciso ressaltar que a publicidade, como principal fonte de recursos para o desenvolvimento da televisão no Brasil, foi a grande responsável pela concretização desse campo social. Aos poucos, a televisão se tornou um espaço de práticas específicas, relativamente autônomo, convencionado pelas interações objetivas e negociações entre atores sociais e instituições. Uma história própria foi orquestrada, assim como papéis, trocas, rotinas, estéticas, tensões, identidades culturais particulares, redes de poder, hierarquias, sistemas de prestígio, relações entre mercados, embates institucionais, conforme as definições de campo social conceituadas por Bourdieu (1983 [1976]).

A solidificação do campo da televisão no Brasil também aponta para uma incorporação ainda maior das mensagens e apelos midiáticos no imaginário social. A televisão é a mídia que, pouco mais de duas década após sua implementação, servirá de integração a um país de dimensões continentais e culturais. Hoje, mais de $95 \%$ dos lares brasileiros ${ }^{64}$ possui um aparelho de televisão, o que faz do dispositivo um instrumento capaz de dirigir os ritmos e os assuntos da vida coletiva. A publicidade como indústria encontra na televisão uma poderosa plataforma para propagar suas narrativas. O consumo da produção simbólica posta

\footnotetext{
${ }^{64}$ Dados do Censo de 2010. www.ibge.gov.br
} 
para circular através da televisão é, portanto, um relevante modo de acesso para compreender as interações sociais, e como as mudanças trazidas pelo setor televisivo interferem e elaboram uma reordenação da vida contemporânea. A paisagem urbana acompanhava o processo de modernização da sociedade, com a adoção de uma arquitetura mais funcional, com edifícios menos adornados e ambientes decorados de forma despojada, seguindo as referências dos grandes expoentes do período, o urbanista Lúcio Costa e o arquiteto Oscar Niemeyer. Para Marialva Barbosa (2007), os aspectos mais ínfimos do cotidiano passam a ser regulados pela centralidade da mídia nas individualidades:

Não é mais apenas a questão do poder da mídia que está em foco. O que está em jogo é a produção de novas sociabilidades reguladas por estes aparatos tecnológicos que instauram relações dialógicas e produzem subjetividade. Os corpos passam a ser, de maneira quase simbiótica, afetados pelas relações de comunicação (...) A voz que vem do rádio restabelece a oralidade e a vocalidade das relações com os meios que nunca deixaram de existir. A voz que vem da televisão reproduz em imagem um mundo como representância. A vida transporta-se para a mídia e os meios de comunicação encerram a vida. (BARBOSA, 2007:147)

Embora a magia do audiovisual despertasse um inegável fascínio na população brasileira desde o início dos anos 1950, a disputa pelas verbas publicitárias só começa a agitar mais incisivamente o mercado televisivo na década seguinte. Surgiram algumas produtoras comerciais dedicadas à televisão, e vimos o início de uma briga pela audiência entre os poucos canais existentes, o que inscreve, definitivamente, o viés comercial do novo veículo que se consolida como uma das principais indústrias do país (Amorim, 2005).

As agências percebem, contudo, uma necessidade de desenvolvimento, que acarretará uma profissionalização crescente. As companhias estrangeiras lideram o processo em suas filiais, como é o caso da JWT e McCann. Duas agências nacionais se dedicam ao processo de expansão de negócios: a Interamericana, de Armando D'Almeida, e a Standard. Esta última, sediada no Rio, abre subsidiárias em São Paulo e depois em quase todo o país.

A Standard teve um grande êxito logo no início da década. Com a construção do Maracanã para a Copa do Mundo de futebol de 1950, a agência cria uma campanha para a venda de cadeiras cativas no estádio, o que irá gerar enorme 
repercussão. Mesmo com a traumática perda do título para o Uruguai, a agência ficou lembrada pela ação bem-sucedida. Para acompanhar o advento da televisão no Brasil, a empresa irá criar seu Departamento de Rádio e TV, chefiado por Ângelo Sangirardi Junior (Abreu; Paula, 2007). A seção representa mais um elo na cadeia produtiva das agências, com atores próprios, funções demarcadas e acordos partilhados, assim como complexifica as disputas e a dinâmica de poderes entre os demais departamentos da empresa.

Em 1958, a Standard passou para a terceira posição no ranking das maiores agências do país, ultrapassada apenas pelas multinacionais JWT e McCann. Enquanto isso, a Inter-Americana seguia firme com seus meticulosos estudos de produção e do mercado consumidor, desenvolvidas por seu Departamento de Estudos Econômicos e de Pesquisas de Mercado (Abreu; Paula, 2007). A criação de setores específicos para cuidar de áreas cada vez mais minuciosas explicitam a ampliação e a influência social do campo publicitário. Quanto maior for o número de elementos complexos dispostos no campo, mais sua multiplicidade e importância social são confirmadas (Bourideu, 1983 [1976]).

A televisão também serviu de mola propulsora para o desenvolvimento da JWT brasileira. Em 1951, a agência produziu a primeira telenovela nacional, Sua vida me pertence, escrita e dirigida por Walter Foster, que também protagonizava a trama junto com as atrizes Vida Alves e Lia Aguiar, naquele momento ainda bastante amador da televisão no país. Desde as radionovelas, a publicidade investe na construção de modelos dramatúrgicos que envolvam os consumidores em torno de formatos rotineiros, uma estratégia para manter a atenção e o interesse por certos produtos. O folhetim, patrocinado pela Coty, era exibido pela TV Tupi de São Paulo apenas às terças e quintas-feiras com capítulos de 20 minutos apresentados ao vivo. A partir de 1952, a JWT realizou os primeiros comerciais filmados. Harry Herrmann foi trazido dos Estados Unidos para ensinar a embrionária técnica aos nossos profissionais. As propagandas da Ford tinham dois minutos de duração e contaram com a assistência de Caio Domingues. A produção dos filmes "Caminhões Ford duram mais" foi feita na Companhia Cinematográfica Vera Cruz, em São Paulo, que contava com uma experiente equipe de técnicos americanos e europeus, entre eles o fotógrafo Chick Fowle. As filmagens ocorreram num velho casarão no bairro de Higienópolis e a exibição era seguida da série americana de filmes dublados "Ford na TV" (Penteado, 2004). 
As agências novamente se articulam, a fim de moldar seus processos produtivos de acordo com os modelos referenciados pelas relações de poder. A matriz se fixa como a fonte do saber e impõe seu conhecimento, como uma espécie de "colonização" cultural. A filial trabalha como mera reprodutora de padrões mercadológicos. Neste processo, é comum a valorização de profissionais externos e não a promoção de agentes internos.

A $J W T$ também foi responsável por uma série de programas televisivos para divulgar seus clientes, como o telejornal Telenotícias Panair, transmitido pela TV Tupi, Um Milhão Probel, programa de distribuição de prêmios, apresentado por Flávio Cavalcanti, Carrossel Kibon, com todo o elenco da TV Tupi e a Grande Gincana Kibon, programa infantil da TV Record conduzido por Vicente Leporace, que ficou no ar por quinze anos. A Kibon também patrocinou a adaptação do Sítio do Pica-Pau Amarelo, inspirado na obra de Monteiro Lobato e dirigido por Julio Gouveia e Tatiana Belinky, além do lançamento do primeiro teleteatro, uma série de treze peças encenadas pelo Teatro Brasileiro de Comédia, levadas ao ar na TV Paulista, sob a direção de Cacilda Becker e Ruggero Jacob (Penteado, 2004). A agência produzia, não só os comerciais veiculados ao vivo nos intervalos, como os programas completos, o que era muito comum na época. Grandes espaços na programação eram comprados para a difusão dos produtos. Como podemos notar, o meio é constituído em grande parte por formatos engendrados pelas agências, o que ressalta o peso da publicidade na organização do campo televisivo no Brasil.

Nesta época, a JWT elaborava estratégias grandiosas para a Kibon. No lançamento da filial da marca em São José do Rio Preto, a Thompson promoveu uma chuva de vales promocionais jogados de um avião e que poderiam ser trocados por pirulitos nos carrinhos espalhados pela cidade. O resultado foi equivalente ao faturamento de um ano da empresa (Penteado, 2004). Nos anos 1960, shows de música transmitidos ao vivo pela TV Rio, que lotavam o estádio do Maracanãzinho, também foram parte das ações de publicidade para a Kibon (Penteado, 2004).

A $J W T$ patrocinou as primeiras transmissões esportivas de televisão pela RCA Victor e Atlantic, em que o apresentador mostrava latas de óleo Atlantic e fotos dos produtos $R C A$ no meio dos programas. $\mathrm{O}$ grande número de comerciais e programas fez com que os setores de Rádio e TV se fundissem na agência, em 
1957. No rádio, os destaques ficaram por conta dos programas Jóias da Literatura, patrocinados pela marca de produtos de beleza Coty, o programa de calouros oferecido pelo Sal de Frutas Eno, a voz da RCA Victor, o programa Boa Noite Martini, todos da Rádio Nacional. A JWT também ficou responsável pela transmissão de futebol da Rádio Tupi, patrocinada pelos pneus Firestone e RCA Victor (Penteado, 2004).

Na segunda metade da década de 1950, a Thompson exibe uma imagem ousada para a época, uma mulher saindo do banho, enrolada em uma toalha. A estratégia foi uma tentativa de modernizar a marca de beleza Coty. A publicidade dos sabonetes Gessy, maior cliente da agência na época, teve a modelo Marta Rocha como estrela e direção de Hélio Silveira e Eric Nice. A Miss Brasil perdeu o concurso Miss Universo de 1954 por duas polegadas a mais no quadril, mas aumentou significativamente as vendas do sabonete em relação a seu concorrente, o Lever (Penteado, 2004).

A McCann também investiu pesado em rádio e televisão, principalmente depois da conquista da conta da Nestlé. Como já colocado, um trunfo da agência foi transformar o sucesso radiofônico do Repórter Esso em programa de tevê, a partir de 1952 na TV Tupi de São Paulo e 1953 na Tupi do Rio. O primeiro campeão de audiência do telejornalismo brasileiro foi apresentado pelos mesmos locutores do rádio, o que gerou muita curiosidade no público, que queria conhecer o rosto daquelas vozes tão populares. $\mathrm{O}$ apresentador era enquadrado em plano americano e começava a ler as notícias pontualmente às oito da noite. A abertura do noticiário ficou muito famosa: “Aqui fala o seu Repórter Esso, a testemunha ocular da história". No início, embora testemunha ocular, contava com pouquíssimas imagens feitas em filme 16 milímetros e fotos recortadas de jornais dos Diários Associados. Em 1969, a atração mostrou, junto com a TV Globo, a chegada do homem à Lua. O programa, apresentado até 31 de dezembro de 1970, declinou com a ascensão de formatos mais modernos, como o Jornal Nacional, da TV Globo, e o Jornal de Vanguarda, da TV Excelsior (Klöckner, 2008).

O aprimoramento da McCann também veio com a Marplan, empresa de análises de opinião de grupo, fundada em 1953 para auxiliar nas pesquisas de mercado da agência. Instituições e outros papéis sociais são incorporados às bases do modo de cooperação da agência. As inovações perduram quando os participantes conseguem incorporá-las às suas atividades correntes. O sucesso é 
decorrente do apoio mútuo entre as partes e a permanência do novo sistema depende da organização líder (Becker, 1977).

A consultoria foi pioneira no uso de computadores para tabulação de pesquisas, no fim da década. Em 1954, o brasileiro Armando de Moraes Sarmento assume a vice-presidência da McCann na América Latina, implanta escritórios regionais em Belo Horizonte e Porto Alegre e funda a Multi Propaganda, segunda agência do grupo no Brasil. A administração de Moraes Sarmento o levou a conquistar o concorrido cargo de presidente da McCann dos Estados Unidos, em 1959. No ano seguinte, já sob a gerência de Emil Farah, a sede da agência é transferida para São Paulo, já que a cidade respondia pela maior parte das receitas. $\mathrm{Na}$ filial carioca ficaram as contas da Coca-Cola e da Esso (Abreu; Paula, 2007).

A partir de meados da década de 1950 surgiram três agências que iriam imprimir novos rumos à propaganda brasileira: Alcântara Machado, em 1954, MPM, em 1957 e Denison, também em 1957. A Alcântara Machado Publicidade - Almap foi fundada na capital paulista por Caio de Alcântara Machado e seu irmão José de Alcântara Machado. A Almap só irá inscrever definitivamente seu nome na história da propaganda brasileira a partir de 1960 com a conquista da conta Volkswagen. A rentável conta da automobilística alemã é incorporada pela direção de planejamento da empresa, que convida o publicitário Alex Periscinoto para fazer anúncios como freelancer. O resultado da campanha foi tão satisfatório que o então Diretor de Propaganda do Grupo Mappin passa a ter sociedade na agência. Periscinoto assume simultaneamente o cargo de Diretor de Criação, alterando o posicionamento dos agentes sociais internos e as redes de poder. $\mathrm{O}$ movimento ocorrido na Almap refletir-se-á nas divisões internas das outras agências no país e representará um passo importante no campo, como veremos no próximo capítulo. Foi a primeira vez que uma agência brasileira incluiu um profissional da Criação na direção dos negócios. O pioneirismo da Almap estava só começando.

Os anos JK abriram novas fronteiras para o campo da publicidade. O nacionalismo desenvolvimentista de Kubitschek, eleito em 1955, despertou a confiança da população e a crença no futuro próspero. Seu lema "50 anos em 5" traduzia a proposta de crescimento econômico e social que culminaria com a construção de Brasília, em 1960, a "metassíntese" de seu "Plano de metas". A transferência do centro político do Rio de Janeiro para o planalto central tinha 
como principal argumento estimular a população a ocupar o interior, já que grande parte da densidade demográfica estava concentrada em regiões litorâneas. O povoamento do centro-oeste levaria à abertura de rodovias para integrar o país. O projeto também se baseou no argumento da segurança nacional, já que uma capital no sertão estaria menos vulnerável a um ataque estrangeiro pelo litoral. A construção da nova capital, desenhada por Lúcio Costa e projetada por Oscar Niemeyer, canalizava esperanças e fazia esquecer os problemas sociais (Cardoso, 1978).

Os esforços prioritários do governo foram nos setores de transporte, energia, na substituição de importações e na indústria de base, para que a população pudesse ter acesso a bens de consumo duráveis e não duráveis (Cardoso, 1978). Estes segmentos totalizaram 93\% dos recursos do ambicioso Plano de Metas, deixando a educação e a agricultura para trás. O presidente queria diminuir a desigualdade social através do crescimento industrial. Para isso, incentivou os investimentos externos e buscou ajuda americana. A entrada de capitais estrangeiros no país foi priorizada, principalmente através da indústria automobilística. Para impulsionar o comércio de carros foi criado o "Grupo Executivo da Indústria Automobilística" (GEIA), que auxiliou na chegada de diversas fábricas do setor, como Volkswagen, Ford, Mercedes Benz, Toyota, General Motors, instaladas no ABC Paulista. O setor energético também ganhou relevância com a construção das usinas Hidrelétricas de Paulo Afonso, no Rio São Francisco e as barragens de Furnas e Três Marias. Na agropecuária, JK aumentou a produção de alimentos. As mudanças provocaram o aumento do Produto Interno Bruto anual em 7\%. Empresas como Cosipa, Brastemp, Metal Leve, Philips e Olivetti também chegaram ao país. Mas o crescimento econômico gerou inflação e dívida externa. A inflação chegou à média anual de 19,4\% e a 39,4\%, em 1959 (Augusto, 2013).

O significativo aumento da dívida pública não foi suficiente para abalar a popularidade de Kubitscheck. Seu período presidencial foi comumente chamado de "Anos Dourados". O estilo de vida moderno, baseado na produção em massa de novas tecnologias, invadia as casas da classe média. Vitrolas elétricas, panelas de pressão, batedeiras, enceradeiras, secadores de cabelo, liquidificadores e televisores foram as grandes novidades (Cardoso, 1978). Nas ruas, os jovens começaram a imitar o astro do cinema americano James Dean, símbolo da 
juventude transviada. Jaquetas de couro e calças compridas desafiavam o clima tropical e impunham o American Way of Life ao terceiro mundo. Na música, o rock and roll e o twist embalavam os mais moderninhos com seus enormes topetes caídos sobre a testa (Savage, 2009).

As agências se apressavam em divulgar o crescimento do país, adotando um posicionamento corporativo, que expressava as virtudes do investimento em publicidade para alavancar as vendas. Como destacam Carrascoza e Hoff (2015), as formações discursivas mais comuns dos anúncios eram voltadas ao conforto, bem-estar e à vida moderna.

Só a expertise publicitária era capaz de lhe abrir todos os mercados que, então, se alargavam. A publicidade era propriamente "dita" como aquela que estreitava a distância entre o produto novo (roupas, eletrodomésticos, brinquedos etc.) e o consumidor curioso por experimentá-lo. Desse dito advinha outro, intensamente explorado pelas agências, por meio do qual elas "chamavam" os anunciantes para investirem com urgência em publicidade. Não bastava anunciar, era preciso fazêlo de imediato não apenas para ampliar a participação no mercado, mas também para não perder market share, já que a competição se acirrava e todas as empresas, dos mais variados segmentos, deveriam aproveitar ao máximo aquele período de prosperidade. (CARRASCOZA; HOFF, 2015: 42)

O espírito de renovação também provocou revisões estéticas e artísticas na literatura, música, cinema, teatro e artes. As comédias musicais da produtora cinematográfica Atlântida fizeram muito sucesso entre o público. O teatro de revista, que misturava humor e música, também teve destaque, assim como o Teatro Brasileiro de Comédia. Nomes como Di Cavalcanti, Volpi, Brecheret, Burle Marx, Oscar Niemeyer, Bonadei, Josué de Castro, Celso Furtado, Sérgio Buarque de Holanda formaram uma geração que ajudou a repensar o país nesse contexto (Cohen, 2006).

A instalação da indústria automobilística no Brasil gerou grandes verbas para as agências de publicidade. Em 1957, a Volkswagen inicia a produção de seu primeiro carro brasileiro, a Kombi, e a Ford lança seu primeiro caminhão genuinamente nacional, o $F$-600, e em seguida a picape $F$-100. A partir de 1959, o automóvel se torna uma realidade comum nas ruas e estradas brasileiras. As grandes empresas, como General Motors, Ford, Volkswagen, DKW-Vemag, Willys Overland, Mercedes-Benz e Romi-Isetta, investiram pesado em 
propaganda. A maior parte do investimento publicitário ainda estava concentrado nos jornais, que detinham $28 \%$ do total, seguido do rádio, com $16 \%$, revistas, com $12 \%$ e televisão, com $6 \%$. Este cenário iria modificar-se completamente a partir da década seguinte, quando a televisão se impõe como maior veículo de propaganda, abocanhando $43 \%$ das verbas do mercado de propaganda, contra $22 \%$ das revistas, $15 \%$ do rádio e $14,5 \%$ dos jornais (Abreu; Paula, 2007).

O I Congresso Brasileiro de Propaganda, organizado no Rio de Janeiro em outubro de 1957, foi um marco para a profissionalização do setor com normatizações para a prestação de serviços pelas agências. Este momento é singular para a estruturação do segmento, pois representa a reunião dos agentes sociais para pensar sobre sua própria estrutura. O campo para, reflete sobre as diretrizes construídas, as conquistas alcançadas e planeja os caminhos futuros. É no horizonte dessa aglutinação de forças específicas e lutas simbólicas que as estratégias de produção são engendradas, tendo por objetivo conservá-las ou transformá-las. Os atores elaboram um espaço de socialização para defender suas formas de atuação, as alianças que estabelecem, as escolas que constroem, correntes de pensamento e assim institucionalizar suas redes de interesses (Bourdieu, 1994). Um campo que pensa sobre si mesmo tem uma representação social expressiva, com número de agentes sociais, instituições, capitais simbólicos, recursos econômicos, convenções, habitus, rotinas de atividades (Bourdieu, 1994). Neste sentido, os congressos irão, sobretudo, reforçar a força do campo no mundo social.

Neste encontro, realizado na Associação Brasileira de Imprensa, foram elaborados o Código de Ética dos Profissionais de Propaganda, as NormasPadrão para o funcionamento das agências de propaganda e criados o Instituto Verificador de Circulação e o Conselho Nacional de Propaganda. As regras elaboradas nesta reunião histórica norteiam a atividade publicitária até hoje, uma vez que instauraram leis de conduta para os diversos integrantes desta indústria: agência, veículos e anunciantes. A Associação Paulista de Agências de Propaganda, com 27 agências fundadoras, também foi embrionária do Congresso, que reuniu mais de mil participantes entre empresários da propaganda, publicitários, anunciantes, fornecedores e veículos de mídia (Abreu; Paula, 2007).

Neste cenário de transformações surgia no sul do país outra grande agência brasileira, que iria se beneficiar do impulso ao setores de transporte e energia. A 
saída do eixo Rio-São Paulo mostra a expansão do mundo da publicidade para outros polos do país, tanto pelo lado qualitativo, quanto pelo quantitativo. Outros espaços entram nas negociações desse jogo corporativo. Resultado da parceria entre Antônio Mafuz, Petrônio Corrêa e Luiz Vicente Goulart Macedo, a MPM foi inaugurada em junho de 1957, em Porto Alegre. Mafuz era dono da agência Sotel, já Petrônio e Macedo trabalhavam na gerência filial gaúcha da Grant Advertising, de onde levaram a conta da Petróleo Ipiranga e das Lojas Renner. Nos primeiros anos, a $M P M$ concentrou-se em clientes locais, seguindo as pretensões dos sócios de ser a mais solida agência no Rio Grande do Sul. O crescimento de seus próprios clientes levou à reformulação dos planos. Com a posse de João Goulart em 1961, após a inesperada renúncia do presidente Jânio Quadros, um novo panorama se desenha para a MPM (Augusto, 2013).

Um quadro de instabilidade política tomou conta do país. Os militares tentaram impedir a posse, alegando que Jango tinha ligações comunistas, e o presidente da Câmara dos Deputados, Ranieri Mazzilli, foi empossado. Com isso, a Campanha da Legalidade, liderada pelo então governador do Rio Grande do Sul, Leonel Brizola, ganha força e exige a posse de Goulart. A campanha mobilizou mais de cem emissoras de rádio e recebeu o apoio dos governos de Goiás e do Paraná. Um acordo político, sancionado pelo Congresso, adotou o parlamentarismo como solução conciliatória para a crise que havia se instalado no país entre militares e democratas (Felizardo, 2003). O presidente assumiria o cargo, como mandava a ordem constitucional, mas parte substancial de seu poder seria deslocado a um primeiro-ministro. No dia 08 de setembro de 1961, Jango é levado à presidência e Tancredo Neves, do PSD mineiro, torna-se primeiroministro. Em julho de 1962, Neves demite-se do cargo para concorrer às eleições para governador. O gaúcho Bernardo Rocha assume o posto de primeiro-ministro, seguido por Hermes Lima. A saída de Tancredo leva Goulart a articular a retomada do regime presidencialista. Um amplo plebiscito foi convocado para que a população opinasse sobre a manutenção do parlamentarismo. O sistema em voga foi amplamente rejeitado e, em 1963, o presidencialismo volta a ser o regime político praticado no Brasil (Felizardo, 2003).

As ligações políticas foram determinantes para o desenvolvimento da MPM. João Goulart era tio materno de Luiz Macedo, o que facilitou a conquista das contas estatais pela empresa, que foi apelidada de "agência chapa-branca". O 
nacionalismo era imperativo no setor de comunicação e não havia licitações, a escolha era feita por indicação direta do Governo Federal. Macedo já tinha trabalhado na campanha de Jango para vice-presidente: naquela época as eleições de presidente e vice ocorriam separadamente. Com o apoio da Rádio Bandeirantes, Jango venceu as eleições com um jingle, composto por Miguel Gustavo, considerado o melhor de todos os tempos por muitos historiadores: "Na hora de votar / O meu Rio Grande vai jangar / É Jango, é Jango, é o Jango Goulart / Pra Vice-Presidente / Nossa gente vai jangar / É Jango, é Jango, é o Jango Goulart”. A música era adaptada para cada estado e a versão nacional vinha com “o brasileiro vai votar", interpretado pelas estrelas do rádio: Elizeth Cardoso, Lúcio Alves e Ângela Maria (Villa, 2004). Como vimos, atores sociais de outros campos são integrados ao processo produtivo da publicidade, aglutinando conhecimento e transformando as rotinas estabelecidas.

Com o tio de Macedo no poder, a $M P M$ também desponta para uma trajetória vitoriosa e estreita as ligações entre o mundo da publicidade e o da política. Logo depois da posse de Jango, a conta da Caixa Econômica Federal foi entregue para a McCann-Erickson. Macedo ficou irritadíssimo e usou o seguinte argumento para reverter a situação a seu favor: "Você, que é nacionalista, como entrega a conta da Caixa para uma agência internacional?" (AUGUSTO, 2013:73). Jango não titubeou e ordenou a troca da McCann pela MPM. Foi o inicio de uma próspera parceria com a publicidade pública. A influência da $M P M$ nos governos seguintes acabou por gerar a implementação da "Lei Macedo", que estabelecia que todas as contas públicas deveriam ser atendidas por agências de capital totalmente nacional (Augusto, 2013).

A tática de Macedo abriu espaço para que as agências se integrassem para garantir exclusividade em uma fatia de mercado muito rentável. Nos anos 1960, as principais lideranças empresariais da publicidade criaram um grupo formado pelas sete grandes agências nacionais: Standart, Norton, MPM, Alcântara Machado, Mauro Salles Publicidade, Denison e DPZ. O seleto clube iria concorrer entre si pelas contas do governo. Foi uma união dos empresários do setor para blindar a concorrência internacional, uma espécie de reserva de mercado. Agora, só as agências "puro-sangue" atenderiam as contas estatais e as disputas seriam mais facilmente negociadas (AUGUSTO, 2013: 147). A mobilização unificada e informal passou a ditar as regras do mercado e recebeu o nome de "Sete irmãs". A 
"Lei Macedo" vigorou até os anos 1990, quando o processo de globalização e as agências internacionais conseguiram tornar inviável sua manutenção (Iribure; Jacks, 2015). Além de ser uma manobra estratégica, o acordo também explicita o peso que o setor da publicidade adquire na configuração política do país.

A $M P M$ começava a romper as fronteiras do Rio Grande do Sul. Para melhor assistir a Ipiranga, Luiz Macedo vem para o Rio de Janeiro abrir um novo escritório, em 1959, o que atrai as clientes como Loteria Federal, Imobiliária Nova Iorque e Colchões Anatom. Para atender as demandas públicas, mais uma filial da agência gaúcha é aberta em São Paulo, em 1960. Petrônio Corrêa mudase para a capital paulista e passa a dirigir esta sede a partir de 1966 (Iribure; Jacks, 2015).

No Rio de Janeiro nascia a Denison, em 1957, como um desdobramento da pequena agência AS Propaganda, fundada por Jurandir Ulisses Arce e Sepp Baendereck no início da década. A empresa foi montada como uma house-agency para atender quase que exclusivamente a Ducal, uma grande cadeia de lojas de roupas para homens. Mas a agência carioca se desenvolveu espantosamente logo nos primeiros anos, aliada ao crescimento do grupo Ducal, que chegou a ter 22 empresas. Com o sucesso da Ducal, importantes marcas do segmento de vestuário se juntaram à agência, como Confecções Sparta (fornecedora do grupo Ducal), Braspérola (fábrica de tecidos), Vulcabrás (calçados), Moinho Santista (camisas), Camisas Torre e Marajó. Logo depois, a empresa ampliou o número de clientes com a indústria de sabão em pó Swift, a gravadora $R C A$ Victor, o frigorífico Armour e as Indústrias Alimentícias Cabeça Branca, da Oetker (Reis, 1990). Já no ano seguinte de sua abertura, o escritório de São Paulo é inaugurado, sob o comando de Hélio Silveira da Motta. No mercado paulista, a Denison passa a concorrer com as maiores agências e conquista a conta dos automóveis Simca, fábrica adquirida mais tarde pela Chrysler (Abreu; Paula, 2007).

Estas três agências nacionais serão de enorme importância para a publicidade brasileira. No próximo capítulo fica evidente o amadurecimento do campo e a mudança de postura internacional frente à nossa produção. $\mathrm{O}$ rápido crescimento e a solidificação do setor publicitário ressaltam o peso do contexto histórico na transformação dos modelos produtivos do segmento. O gigantesco crescimento dos meios de comunicação de massa serviu para difundir novos valores e integrar culturalmente diferentes espaços geográficos. Ricas 
manifestações culturais conviveram com autoritarismo político e severas repressões. No entanto, o forte desenvolvimento econômico do período impulsionará mudanças significativas na publicidade, no rastro das mutações que já vinham impactando a indústria nos Estados Unidos e na Europa. 


\section{5 - A consolidação do campo publicitário}

Os anos 1960 foram tomados por um espírito de modernidade e renovação que invadiu diversos setores da vida social. Ao redor do mundo, a ideia de revolução contaminou as perspectivas ideológicas dos campos da política, economia e cultura (Couto, 1999). Já no início da década, muitos países ocidentais deram uma guinada à esquerda, inspirados pela vitória de John Kennedy nos Estados Unidos e pela eleição do trabalhista Harold Wilson, em 1964, para o cargo de primeiro-ministro do Reino Unido. No Brasil, João Goulart se torna o primeiro presidente trabalhista, em 1961 (Couto, 1999).

A Guerra Fria, instaurada com o fim da Segunda Guerra Mundial, trouxe uma divisão que foi muito além dos conflitos indiretos e disputas estratégicas entre Estados Unidos e União Soviética. A dicotomia do confronto gerou uma partição de ideais, uma luta de rivalidades que se disseminou, ao menos como ideologia, pelo planeta. A Guerra do Vietnã, que afligiu o sudeste asiático entre 1959 e 1975, foi, sobretudo, um símbolo desta hostilidade. De um lado, o Vietnã do Sul defendia o capitalismo, escorado pelos Estados Unidos. Do outro, o Vietnã do Norte e a Frente Nacional para a Libertação do Vietnã possuíam orientação comunista e contavam com o apoio da União Soviética, China e Coreia do Norte. Após derrotas consecutivas e sem o apoio da população que perdia seus filhos no conflito, os Estados Unidos aceitaram o Acordo de Paris e retiraram suas tropas do longínquo país asiático. O Vietnã do Norte se declara vitorioso, e em julho de 1976 é reunificado sob o regime comunista (Harper, 2011).

Todos estes embates que sacudiram a década foram potencializados pela camada social que está mais aberta à mudança, mais propensa à experimentação e ao risco: a juventude. A geração "Baby Boom”, que designa os filhos nascidos entre 1945 e 1950, com a volta para casa dos soldados da Segunda Guerra, cresceu e liderou as contestações sobre as estruturas sociais rígidas, os sistemas de ensino, a sexualidade, os costumes, a moral e a estética. A divergência de valores entre pais e filhos acabaram acendendo grandes conflitos contra o autoritarismo em diversas esferas dos modelos vigentes. Na música, no cinema, no rádio, na 
publicidade, o jovem passa a ser uma voz ouvida e ter gostos valorizados por um mercado consumidor que crescia cada vez mais (Savage, 2009).

Inspirados por ideias de liberdade, as mudanças do comportamento jovem darão origem a um movimento maior chamado de "contracultura", que vinha apregoar a realização de projetos culturais alternativos. O ideário contestador da contracultura encontrou no jovem o seu maior expoente. Segundo Messeder Pereira (1992), a revolução contracultural pode ser caracterizada por uma tomada de consciência juvenil, com atitudes e protestos (em sua maioria, pacíficos), discordância do sistema capitalista e dos princípios da economia de mercado. Entre os aspectos mais destacados estavam a valorização da natureza, a vida em comunidade, a alimentação natural, a luta contra qualquer tipo de repressão, o respeito às minorias, a experiência com as drogas, o culto à religiosidade oriental e a liberdade sexual.

Apesar da crítica ácida desses grupos jovens aos meios de comunicação, o gigantesco crescimento dos veículos provocou a difusão dos novos valores e padrões de comportamento. A mídia massiva ajudou a desenvolver na juventude uma sensação de independência, com a liberação das amarras tradicionais e locais, especialmente as familiares e religiosas (Groppo, 2000).

Muitos destes significados sociais que se conectam ao propósito não conservador que a juventude buscava foram edificados pelo universo do consumo. Luís Antônio Groppo (2000) coloca que as experiências sociais vividas pela juventude do período serão completamente diferentes das vividas pelos adultos da geração anterior, quando estes eram jovens. A narrativa publicitária vai explorar a força desse segmento social a partir dos anos 1960, seja criando simbolismos que vão referenciar grupos ou "tribos", seja exalando um discurso de "juvenilização" da sociedade ocidental como um todo. A ideia do jovem se torna um grande motor da indústria cultural e está intimamente associado à noção de lazer, ambas construídas culturalmente (Rocha; Pereira, 2009). A relação juventude-lazer se tornou substancial à cultura de consumo e abriu possibilidades para a autonomia dos jovens, uma vez que os colocou à frente da criação das formas de lazer contemporâneas. Groppo (2000) lembra ainda que, durante o século XX, os jovens se tornaram o grupo social mais atuante na programação radiofônica, televisiva, cinematográfica e ainda como consumidores de música popular, 
esportes, revistas, videocassetes, frequentadores de boates, espetáculos, entre outras formas de lazer cultural.

$\mathrm{O}$ rock and roll ganha popularidade em todo o mundo e vira febre com o aparecimento das icônicas bandas Beatles e Rolling Stones. O ritmo era comumente associado à rebeldia política. Movimentos musicais sinalizaram com suas músicas de protesto. Os Beatles lançam, em 1967, Sgt. Pepper's Lonely Hearts Club Band, álbum considerado o melhor da história da música e também um dos mais vendidos (Muggiati, 1983). A conceituada revista Time o referenciou como "uma partida histórica no progresso da música". A banda tinha anunciado que não faria mais shows devido à complexidade de seus arranjos, difíceis de ser executados ao vivo, e por conta da histeria dos fãs que não os deixava ouvir o que tocavam. Em 1969 ocorre o Festival de Woodstock, nos Estados Unidos, com apresentações de nomes clássicos do rock como Jimi Hendrix, The Who, Carlos Santana. O encontro de três dias ficou marcado pela exaltação à ideologia "paz e amor" e ao consumo de drogas, acentuando a popularidade do comportamento hippie. As questões ambientais, o nomadismo, a emancipação sexual e os protestos contra a guerra formavam princípios destes grupos, oriundos da contracultura (Muggiati, 1983).

Um dos marcos emblemáticos da rebeldia dos anos 1960 foi o movimento de maio de 1968, quando uma insurreição popular instalou uma greve geral na França. Muitos filósofos e historiadores consideram este acontecimento um dos mais importantes do século XX, porque não ficou restrito a uma pequena camada da população, mas atingiu todos os setores, superando barreiras étnicas, culturais, etárias e de classe. Uma série de greves estudantis irromperam nas universidades e escolas de Paris, travando confrontos entre os jovens e a polícia. O autoritarismo do governo de Charles de Gaulle fez com que o conflito evoluísse para uma greve geral de estudantes e de fábricas em todo o país, com adesão de dois terços dos trabalhadores franceses. A maioria dos revolucionários apoiava ideias esquerdistas, comunistas e anarquistas e queria perturbar os valores da sociedade conservadora (Cohn; Pimenta, 2008).

O clima contestador do movimento jovem também foi gerado pelo aparecimento da pílula anticoncepcional, que acendeu revoluções comportamentais em torno do feminismo e da sexualidade. A forma de se vestir também estava cada vez mais ligada ao estilo pessoal. Conscientes desse novo 
mercado consumidor, empresas criam produtos específicos e os jovens passam a ter sua identidade refletida no vestuário. A minissaia desponta como a grande vedete, acentuando os efeitos de uma nova atitude. A inglesa Mary Quant e o francês André Courrèges foram os criadores dessa peça que invadiu as ruas de Londres e Paris (Boucher, 2010).

No Brasil, manifestações culturais fizeram do período um dos mais prósperos da música popular. Em 1963 surgia o Clube da Esquina, com Milton Nascimento e os irmãos Borges. O movimento fundia inovações da Bossa Nova com o jazz e o rock and roll. Na televisão, começam a aparecer os grandes festivais da canção, que movimentaram multidões. O I Festival da Música Popular Brasileira, da TV Excelsior, é até hoje lembrado pela eloquente interpretação de Elis Regina para a música Arrastão, de Vinicius de Moraes e Edu Lobo. Em 1965, estreia o programa Jovem Guarda, na TV Record, apresentado por Roberto Carlos, Erasmo Carlos e Wanderleia. O sucesso foi tão grande que acabou suscitando a criação de um movimento musical com o mesmo nome. Foi a primeira vez que adolescentes se viram retratados na cena televisiva (Monteiro, 2014a). A Bossa Nova, surgida no fim da década anterior, também tem seu ponto alto nos anos 1960. O estilo ficou caracterizado pela mistura de samba, música erudita e jazz americano e teve êxito em todo o mundo. Segundo o jornal $O$ Estado de S. Paulo, "bossa nova" foi a expressão de maior uso comercial e publicitário do ano de $1960^{65}$.

O clima de protesto gerado no III Festival da Música, da TV Record, envolvendo o uso de guitarras elétricas e discussões com a plateia, impulsionou Caetano Veloso, Gilberto Gil, os Mutantes, Tom Zé, Torquato Neto a criar o Tropicalismo, em 1967. As experiências teatrais de José Celso Martinez Correa com o grupo Teatro de Oficina, as artes visuais de Hélio Oiticica e filmes importantes como Terra em Transe (1967), de Glauber Rocha, Macunaíma (1969), de Joaquim Pedro de Andrade, e Brasil Ano 2000 (1969), de Walter Lima Junior também foram incluídos como expressões tropicalistas. O movimento propunha uma vanguarda cultural com a junção de elementos da cultura nacional com a estrangeira. O manifesto antropofágico do escritor Oswald de Andrade foi retomado para discutir as amálgamas brasileiras, os vínculos entre o nacional e o

\footnotetext{
${ }^{65}$ Fonte Acervo $O$ Estado de S. Paulo: http://acervo.estadao.com.br/noticias/topicos,bossanova, $434,0 . h t m$
} 
estrangeiro, o urbano e o rural, a alta cultura e a cultura de massa (Machado, 2011).

Apesar de muito rico culturalmente, o período foi também distinguido por conflitos políticos. Em 1964, o golpe deflagrado pelos militares encerra o governo do presidente João Goulart. As forças políticas lideradas pelos militares contaram com apoio de segmentos importantes da sociedade civil, como parte das camadas médias urbanas, burguesia industrial paulista, proprietários rurais e alguns setores conservadores da Igreja Católica. Problemas de estabilização econômica, com uma inflação de $100 \%$ ao ano, dívida externa, pressão do Fundo Monetário Internacional, corrupção interna e o suposto avanço comunista levaram os militares a instaurar o novo regime a partir da noite de 31 de março de 1964 (Gaspari, 2014a).

O Marechal Castelo Branco é eleito pelo Congresso como o primeiro presidente do governo de exceção. O golpe de Estado trouxe profundas mudanças na vida social do país através de um regime autoritário e nacionalista, alinhado politicamente aos Estados Unidos. Repressões a ativistas de esquerda, cassações de mandatos, exonerações de funcionários públicos civis, prisões, torturas de líderes das ligas camponesas e religiosas e de estudantes marcaram o período (Gaspari, 2014b).

Embora fortemente repressor, a ditadura instaurada apontou soluções econômicas que transformaram a vida cotidiana brasileira, sobretudo com o forte apoio de capitais estrangeiros. O processo de "modernização" conferiu um volume e dinamização que ampliou significativamente as dimensões do mercado. A noção de progresso, trazida para a área econômica, estimulou a criação de um mercado consumidor de bens materiais e simbólicos importante. A ambígua relação entre repressão política de um lado e expansão econômica de outro fez com que muitos setores conservadores da sociedade vissem a transferência de poder com bons olhos. A reorganização econômica conferiu novo fôlego ao mercado e fez de 1964 um marco importante, como explica Renato Ortiz (1985):

(...) inaugura um período de enorme repressão política e ideológica, mas significa também a emergência de um mercado que incorpora em seu seio tanto as empresas privadas como as instituições governamentais. Durante o período 64-80 ocorre uma formidável expansão, a nível da produção, da distribuição e do consumo dos bens culturais. (ORTIZ, 1985: 83) 
Amparado na doutrina de Segurança Nacional, o Estado passa a estimular a produção midiática como forma de integração política e geográfica. A Escola de Guerra das Américas, com sede na Cidade do Panamá, mantida pelos Estados Unidos, orientava os governos aliados do continente a expandir suas redes de telecomunicações (Amorim, 2005). Um país com dimensões continentais como o Brasil precisava se unir em torno de um governo central e acreditava-se que essa união só seria possível com a integração de redes nacionais de rádio e televisão.

Com o incentivo ao setor das comunicações, a publicidade foi percebida como fundamental para o desenvolvimento do país. A Assessoria Especial de Relações Públicas, Aerp, implementada plenamente durante o governo Médici, a partir de 1969, foi um organismo criado para camuflar posições negativas ao governo e acirrar o nacionalismo junto à população. A Aerp trabalhava em cima da imagem dos presidentes como pessoas acessíveis, com campanhas e slogans que exaltavam o patriotismo. A intenção não era promover manifestações a favor do governo, e sim ocultar os sentimentos revoltosos. As comunicações foram usadas em favor da ordem e do consenso (Fico, 1997).

A política de industrialização e as reformas estruturais logo deram resultados com inflação controlada e crescimento econômico de 4,7\% em 1967 e 11\% em 1968 (Martins Filho, 2011). O período ufanista foi apelidado de "milagre econômico". Contraditoriamente, o "milagre" também gerou concentração de riqueza e aumento da pobreza. O ministro da fazenda Antônio Delfim Neto foi o principal articulador das mudanças de expansão de crédito e controle de preços e salários e ficou conhecido como o "super-ministro". A indústria de automóveis cresceu $19 \%$ e a de eletrodomésticos, 13\% (Augusto, 2013). Com o aumento do número de trabalhadores nas fábricas temos a consolidação da classe média brasileira. A publicidade foi o maior instrumento para promover a renovação dos desejos de consumo da população (Augusto, 2013).

O golpe colocou em alerta os três sócios da $M P M$, que temiam retaliação pelo parentesco de Macedo com o presidente deposto e pelo fato de a empresa ter feito a campanha "Diga não ao parlamentarismo" com o jingle "Vamos Jangar", de Miguel Gustavo, em 1961. Depois da conquista da conta da Caixa Econômica, a agência também passou a atender o Banco do Brasil e a Eletrobrás. Os concorrentes logo ficaram de olho para tentar virar o jogo e conseguir um daqueles rentáveis clientes. Uma articulação política de Macedo com o senador 
Daniel Krieger garantiu a estabilidade da $M P M$ nos anos de chumbo (Augusto, 2013). Independentemente de ideologias, podemos notar que a publicidade se cruza com qualquer esfera de poder, desde que opere segundo a lógica capitalista. O setor se baseia no tripé "capitalismo, mercado e mídia”, e se posiciona ao lado das instâncias que concentram poderio econômico. Neste sentido, mesmo em ditaduras políticas de valores muito autoritários, a atividade publicitária foi constante, uma vez que o sistema financeiro capitalista continuava a operacionalizar os negócios.

Logo depois, a MPM conquistou a conta do Instituto Brasileiro do Café, $I B C$, o que agregou muito prestígio político. No fim de 1964, o governo promoveu a política de erradicação do café para manter os preços no mercado internacional. A agência ficou responsável por comunicar a mudança à população através de campanhas. A aquisição desta importante conta fez com que um escritório fosse aberto em Brasília. A escalada de crescimento não parou por aí. Em 1967, a MPM incorporou a empresa PDP Propaganda (Propaganda, Divulgação e Produção), fundada por Décio Pignatari, Hermelindo Fiaminghi e Paulo Augusto de Almeida (Abreu; Paula, 2007).

A transferência da capital para Brasília ocorrida em 1960 e o forte processo de industrialização em São Paulo, estimulado pelo setor automobilístico, fizeram com que o mercado do Rio de Janeiro perdesse hegemonia pouco a pouco. Até os anos 1950, a capital fluminense era o principal polo de publicidade do país. Minas e Rio Grande do Sul também começavam a despontar como promissores espaços profissionais. $\mathrm{O}$ aprimoramento do setor fez com que os militares aprovassem o Código de Ética dos Profissionais de Propaganda logo no início do novo regime, em 1964. Como não tinha status de lei, a medida não provocou efeitos práticos no cotidiano das agências. A fim de mudar essa situação, lideranças paulistas como Geraldo Alonso e Paulo Arthur Nascimento criaram a Federação Brasileira de Publicidade (Febrasp), uma entidade nacional que englobaria todas as associações de profissionais. Petrônio Corrêa, da MPM, assumiu a presidência e conseguiu aprovar a mais importante legislação da publicidade brasileira (Augusto, 2013).

A Lei $\mathrm{n}^{0} 4.680$, de 18 de junho de 1965, regulamentou juridicamente o exercício da profissão de publicitário e do agenciador de propaganda. $\mathrm{O}$ artigo $1^{\mathrm{o}}$ dizia que "São Publicitários aqueles que, em caráter regular e permanente, 
exerçam funções de natureza técnica da especialidade, nas Agências de Propaganda, nos veículos de divulgação, ou em quaisquer empresas nas quais se produza propaganda". E o artigo $5^{\circ}$ completava: "Compreende-se por propaganda qualquer forma remunerada de difusão de ideias, mercadorias ou serviços, por parte de um anunciante identificado" ${ }^{\prime 66}$. No ano seguinte, o Decreto $\mathrm{n}^{0} 57.690$, de 01 de fevereiro de 1966, aprovava a execução da lei e ainda reforçava as normas estabelecidas no I Congresso de Propaganda, em 1957.

A lei padronizou a forma de atuação das agências, assegurando às empresas o direito a uma comissão de $20 \%$ sobre os valores pagos com veiculação de mídia. $\mathrm{O}$ artigo 11 também tornava obrigatória a adoção de uma tabela de preços onde não se podia conceder “(...) nenhuma comissão ou desconto sobre propaganda encaminhada aos Veículos de Divulgação por qualquer pessoa física ou jurídica que não se enquadre na classificação de Agenciador de Propaganda ou Agência de Propaganda." (Lei $\mathrm{n}^{0} 4.680$, art. 11). A medida evitava a barganha para oferecer menores preços aos anunciantes. Agora, o cliente escolhia a agência pela qualidade de seus serviços. Com isso, acabava a prática da corretagem de espaços publicitários nos jornais, revistas e emissoras de rádio e televisão, que ainda associava a função de publicitário à de um simples vendedor. A legislação veio fortalecer a imagem e a representação social da profissão, que consegue se desvincular do perfil de "vendedor" ou "pedinte" de anúncios, muito comum nas primeiras décadas do século XX. As conquistas trazidas pela Lei $n^{\circ} 4.680$ representam a consolidação jurídica das disputas anteriores do campo publicitário. Garantir o reconhecimento da profissão e assegurar a padronização de atividades por direito é a expressão máxima das estruturas, interesses, negociações, embates políticos e formas de organização dispostas por um mundo social. A lei assegura perante os outros setores o reconhecimento da gênese social de um campo, a crença que o sustenta, a linguagem que utiliza e os materiais que produz (Bourdieu, 1994).

Novos anunciantes, novas empresas no Brasil, organização do campo publicitário, aumento de verbas em circulação e a cobertura nacional dos meios de comunicação, estimulada pela ditadura militar, abrem um imenso horizonte para a

\footnotetext{
${ }^{66}$ Disponível em: http://www.planalto.gov.br/ccivil_03/leis/14680.htm
} 
atividade. É o início dos chamados "anos de ouro" da publicidade brasileira (ABAP, 2005).

\section{1 - A ênfase na criatividade}

Se o Brasil entrava em um período próspero da indústria publicitária, na Madison Avenue as agências já eram as grandes protagonistas do sucesso das marcas. A famosa Avenida de Nova Iorque virou sinônimo de indústria da publicidade americana por concentrar a maioria dos escritórios das empresas do setor. A propaganda objetiva e criativa feita em parceria com os clientes dava o tom dos trabalhos exportados para todo o mundo. Hoje, muitas agências já se mudaram para outras partes de Manhattan, mas a avenida ficou imortalizada no mercado de propaganda. Além das agências, a Madison Avenue, vizinha da Quinta Avenida, concentra também famosas lojas de vestuário, como Chanel, Jimmy Choo, Dolce \& Gabbana, Hermès.

O seriado Mad Men (EUA, 2007), exibido pelo canal de televisão americano por assinatura $A M C$, remonta o glamour que a publicidade norteamericana atingiu nos anos 1960. O protagonista Don Draper, interpretado pelo ator Jon Hamm, é um publicitário que encarna um lugar que, aos poucos, vai se tornando central no campo. O personagem é construído com base no estereótipo dos profissionais de sucesso que gravitavam no setor. Ambiciosos, machistas, fumantes, infiéis com suas esposas e articuladores de uma infinidade de manobras para vender um produto ou conquistar um cliente. As agências assumiram o papel de vender o sonho americano, incorporado no consumo. A série mostra a complexa mudança social que o mundo atravessava através da produção de campanhas publicitárias. Desta forma, Mad Men resgata a montagem de um mundo profissional em torno da agência. A empresa fictícia Sterling Cooper não é apenas o cenário principal, é o palco onde serão construídas as condições de existência da narrativa publicitária e do acontecimento social do anúncio. As convenções e produtos desse mundo são gerados através das negociações e atividades coletivas ocorridas na instituição. Sem a agência, a publicidade seria 
uma atividade dispersa, sem normatizações, escalas rotineiras, eixos de dependência coletiva e redes de poder. O modelo confirma a Teoria da Ação Coletiva de Howard Becker (1977), que compreende as interseções e correlações entre os diferentes meios internos e externos como formas de representação da sociedade.

Mad Men também resgata o imaginário de uma época e expõe com clareza o papel dos bens materiais como plataformas para o entendimento e interpretação de uma cultura e da construção de subjetividades em determinado tempo histórico. A série evidencia a representação cultural formada em torno da imagem do publicitário. Os altos cargos da agência são ocupados por executivos muito bem remunerados por sua atuação e adeptos de um estilo de vida que esbanja conforto e luxos materiais. A rotina da agência também reforça o aspecto não convencional deste ambiente profissional. Os funcionários não precisam cumprir a carga horária de oito horas por dia e também não se atêm a regras de etiqueta comportamental. Cenas com personagens com os pés em cima da mesa ou bebendo doses de whisky no horário de trabalho são frequentes. O diferencial do publicitário está relacionado à sua capacidade criativa e aptidão para conquistar novos clientes. Características altamente subjetivas compõem o leque de habilidades necessárias para se tornar um integrante de uma agência, como vivacidade, perspicácia, esperteza, facilidade de relacionamento. A arquitetura da empresa é recortada por salas fechadas e longos corredores onde estão as mesas das secretárias. Cada gestor tem sua própria sala, que varia de tamanho de acordo com o posto ocupado. Em geral, as decisões são tomadas a portas fechadas.

Ao longo das sete temporadas - que chegaram ao fim em 2015, depois de oito anos de exibição - podemos perceber uma mudança fundamental que transformou as agências americanas e depois foi incorporada pelo mercado brasileiro ao longo dos anos 1960. No início da década ainda não havia "duplas de criação". Os Redatores trabalhavam separados dos Diretores de Arte. Os textos eram preparados e discutidos com os gerentes de contas antes de passar para o desenvolvimento de suas artes gráficas. As salas destes dois profissionais também ficavam distantes, em andares diferentes das agências. Não existia um diálogo mais próximo e uma atividade conjunta para a elaboração de uma estratégia de campanha. Por volta da quarta temporada de Mad Men esse movimento começa a ocorrer na Sterling Cooper. O personagem Stan Rizzo, interpretado pelo ator Jay 
R. Ferguson, é incorporado à empresa e forma uma parceria com a redatora Peggy Olson, vivida por Elisabeth Moss. A junção é marcada por muitas discussões e atritos. As mudanças intencionais afetam as redes de colaboração e atacam, tanto de forma ideológica, quanto de forma institucional, as atividades características de um mundo social. Nesse sentido, embates, manifestos, críticas, reformulações são constantes, até que a inovação se torne a base de um novo modo de cooperação, uma ação corrente (Becker, 1986).

Fora do universo da ficção, essa configuração foi inicialmente sistematizada pela agência nova-iorquina $D D B$. Em 1949, os publicitários Bill Bernbach, Ned Doyle e Mac Dane se uniram para fundar a Doyle, Dane \& Bernbach, ou simplesmente $D D B$, responsável por articular em torno de si técnicas que impactaram o mercado mundial. Ao instituir as "duplas de criação" e a figura do Diretor de Criação, a $D D B$ inaugura o modelo de organização das agências que é adotado até hoje.

As empresas foram hierarquizadas segundo o mérito da criatividade. Redatores e Diretores de Arte passaram a trabalhar em conjunto, dividindo, inclusive, o mesmo espaço físico. O resultado da parceria tinha que ser aprovado pelo Diretor de Criação. Bill Bernbach fez da agência um espaço de produção funcional e ágil, o que lhe rendeu a fama de maior publicitário da história (Mayer, 1986). A propaganda passa a ser encarada como um negócio criativo. A $D D B$ inovou com publicidade comparativa, anúncios visuais e até interatividade (Bernbach, 2003).

A ironia e o tom provocativo das mensagens mudaram a maneira de pensar as narrativas. As ideias desenvolvidas eram originais porque não descreviam os produtos, queriam despertar emoções nos consumidores. No lugar do racional, no limite, o tom didático com o objetivo de "explicar" os produtos e serviços, a propaganda começa a perceber o lado emocional para acelerar as vendas. Assim, a criatividade assume gradativamente a liderança do negócio e passa a ser o elemento-chave que regerá as ações publicitárias (Mayer, 1986). Para sobreviver, as multinacionais do segmento precisaram se adaptar ao novo modelo. $\mathrm{O}$ mercado americano copiou literalmente as mudanças trazidas pela $D D B$, e em seguida todo o mundo se rendeu ao padrão que ficou conhecido como "revolução criativa" (Bernbach, 2003).

A $D D B$ criou o primeiro anúncio interativo da história ao apresentar a foto 
de um homem com metade do cabelo branco e metade do cabelo pintado de preto. A legenda dizia: "Ponha sua mão na metade grisalha e veja como remocei" (Cardoso, 1998). O leitor podia assim comprovar o resultado da tintura para cabelos. Outro grande destaque da empresa foi a ousada campanha para o Fusca, carro alemão da Volkswagen. O automóvel não apresentava inovação tecnológica, era pequeno e considerado feio em relação aos outros designs apresentados pela indústria automobilística. O expansionismo do setor desde os anos 1950 era refletido em carros grandes, pesados, coloridos, com partes cromadas para exibir brilho e caudas longas. A propaganda da época ressaltava o desejo dos consumidores em torno de um carro fetiche, que exaltasse poder. O Fusca era o oposto de tudo isso. O carro também era considerado nazista, pois foi admirado por Hitler. Com isso, a população de Nova Iorque, com grande número de judeus, era antipática a este "carro do povo". A $D D B$ então surpreende com o slogan "Pense pequeno", considerado o melhor do século XX pela revista Advertising Age (Meio e Mensagem, 1999). A ilustração mostrava um carro pequeno em meio a um grande espaço em branco. $\mathrm{O}$ anúncio não destacava a ilustração. Como de costume, tinha um título curto demais e não continha as palavras "novo" ou "grátis" em seu texto, apresentado sem margem e serifa. A propaganda queria ressaltar o baixo custo de manutenção, preço e seguro mais baratos. Quando visitou a sede da $D D B$ em Nova Iorque, em meados dos anos 1960, o publicitário brasileiro Alex Periscinoto, da Almap, ficou abismado quando se deparou com aquele layout, de que nunca se esqueceu:

Aquilo era de uma ousadia tremenda, de uma criatividade extraordinária. Naquela época, todos os anúncios de carro eram coloridos, com gente extravagante, dando a entender um estilo de vida voltado para pensar grande, o American way of life, "The car you waiting for" - aquelas cartas marcadas, bem burrinhas. De repente o cara saca aquela de pensar pequeno. (PERISCINOTO, 1998:36)

Inicialmente, Periscinoto não sabia da existência da empresa de publicidade americana, apenas estava interessado em descobrir como eram produzidos os originais anúncios da popular loja de departamentos Ohrbach's, veiculados em jornais. Depois de muita insistência, conseguiu ser recebido na agência. Na $D D B$ aprendeu que a criação funcionava em duplas, com Redator e Diretor de Arte em sintonia, e viu ambos interferindo em textos e layouts de 
forma complementar. A agência tinha uma divisão de tarefas bem definida entre os sócios: Bill Bernbach era Diretor de Criação, Maxwell Dane, Diretor Financeiro, e Ned Dogle, Diretor de Contas. O tripé se tornou o trunfo do negócio para Periscinoto, que ao voltar para o Brasil, levou o modelo para a Almap ${ }^{67}$.

Até o início dos anos 1960, nossas agências ainda não apresentavam composições tão bem divididas. A JWT, a McCann, a Standard e a Lintas eram as mais refinadas estruturalmente. Em geral, no Departamento de Arte estavam concentrados os profissionais que desenhavam, faziam ilustrações, letras à mão e layouts. O Departamento de Pesquisa ainda era muito precário. O restante dos profissionais estava misturado entre as funções de redação, contatos, planificação, mídia, rádio, gravação, tráfego e contabilidade (Periscinoto, 1998). Assim que assumiu a sociedade e a direção criativa da Almap, Periscinoto colocou em prática o que havia aprendido na $D D B$ e chefiou o primeiro Departamento de Criação com duplas do país. O tripé igual ao da agência americana seria fechado com José Alcântara Machado à frente das relações públicas e administração e Otto Schreb, responsável pelos clientes e gerência da empresa. Assim, a revolução provocada pela $D D B$ chegava ao Brasil.

As inúmeras campanhas que a Almap fez para a Volkswagen foram inspiradas no estilo criativo da $D D B$, com duplas de Redatores e Diretores de Arte interagindo, trocando ideias, invertendo papéis. Uma delas trazia o desenho de quatro pneus soltos que ocupavam uma página inteira, com o texto logo abaixo: "Compre o carro que tem só quatro coisas que enchem". Outro exemplo de anúncio mostrava apenas a metade de um Fusca com os dizeres: "É isso que ele estaria valendo depois de um tempinho, se não fosse um Volkswagen" (PERISCINOTO, 1998: 83-89).

A ousada proposta, baseada na aquisição de talentos do mercado, não foi aceita facilmente pela Almap. A filosofia da empresa fora construída com base na individualização de tarefas e não no entrosamento da equipe. Disputas e resistências das instâncias de poder marcaram esse momento de transformações, como relembra Periscinoto:

\footnotetext{
${ }^{67}$ Entrevista para a tese.
} 
A Almap trouxe esse frescor do trabalho em dupla para o campo da publicidade, de ter uma autoridade criativa na agência que contratava as pessoas que queria. Quem entrevistava as pessoas era o Diretor de Criação e não um administrador. Já na conversa você sentia a capacidade de imaginação do candidato ${ }^{68}$.

Para implementar o mesmo organograma da $D D B$, Periscinoto precisou retornar à agência americana junto com a direção administrativa da Almap. A agilidade da produção e a prosperidade da empresa estrangeira evidenciaram a eficiência do modelo para os brasileiros. Seis meses depois daquela ida a Nova York, o gerente Otto Schreb sai da Almap, em 1962, para fundar sua própria agência, a Proeme, levando consigo a conta da Volkswagen e vários profissionais.

Dois anos depois, em 1964, a Almap reconquista a conta da automobilística, inscrevendo a agência no roll das maiores empresas de publicidade do Brasil. O impulso mercadológico contou com a participação do Diretor de Planejamento Helio Silveira da Mota, vindo da Denison. Esse setor da Almap foi considerado o grande precursor das ações de planejamento publicitário no país. Nos anos 1950, uma tecnologia foi criada para registrar a audiência de um grupo de lares, chamado de "tevêmetro". O instrumento, instalado nos domicílios, funcionava como um tipo de fita telex, que informava a sintonia por minuto, assinalando automaticamente quando o telespectador mudava de canal. O dispositivo só passou a ser usado efetivamente em 1969, mas representou um avanço na medição de audiências (Abreu; Paula, 2007). A inovação em uma cadeia produtiva provoca transformações nas concepções autorais ou altera os circuitos rotineiros, no limite suporta o nascimento de produtos e aspectos até então desconhecidos. Nesse sentido, a utilização de novos materiais, técnicas e artefatos por um lado alteram o processo criativo, por outro permitem a criação de novos mundos. Em grande medida, a inserção de novas tecnologias reelabora convenções e permite que os participantes colaborem de formas diferentes, acomodando mudanças paulatinas ao campo. Conforme a experiência apresenta resultados, outras instituições aderem à inovação e ela se torna uma ação rotineira e uma convenção organizacional (Becker, 1986).

A boa fase dos negócios leva a Almap a reformular completamente o escritório de São Paulo. A agência investiu em diversas técnicas de pesquisa como

\footnotetext{
${ }^{68}$ Entrevista para a tese.
} 
forma de oferecer subsídios ao processo criativo. A renovação começou com a implantação de uma nova metodologia que priorizava o "pré-teste" dos produtos. Consumidores eram reunidos em uma sala espelhada e entrevistados por psicólogos, sem saber que do outro lado do vidro estavam sendo observados pela equipe de criação da agência. Aprovação e rejeição dos objetos pelo grupo e até expressões corporais eram analisados para o desenvolvimento das campanhas.

O modelo foi inspirado no caso de sucesso dos testes com consumidores feitos pela marca de cigarros Malboro. Para não perder a conta para a concorrência, a estratégia foi construir grandes cones com lentes internas e produzir pequenos filmes com imagens diversas de animais, carros, mulheres, cavalos, paisagens, crianças. Os analistas já sabiam que quando alguém se entusiasma com algo, a pupila dilata imediatamente. Os consumidores assistiram a estas projeções pelo cone, enquanto uma equipe marcava se as pupilas dilatavam ou retraíam. A maioria dos participantes dilatou a pupila com as imagens de cavalo e respondeu que as cenas destes animais remetiam a uma atmosfera calma, serena, distante da família e dos compromissos cotidianos. Assim foi criado o famoso slogan: Come to Malboro country. Where the flavour is (Venha para onde está o sabor. Venha para o mundo de Malboro) (Periscinoto, 1998).

À medida que as agências aperfeiçoam suas técnicas, identidades culturais e competências oriundas de outros mundos sociais são agregadas ao negócio da publicidade. Saberes acumulados por setores diversos vão se aglutinando para aprofundar o conhecimento do campo publicitário. Fica explícita a contribuição da interdisciplinaridade e da ação interacionista para o incremento do campo, que se diversifica e tece novas redes de colaboração.

As pesquisas na Almap também foram aprimoradas com o método "Monitor", uma espécie de investigação qualitativa em que um entrevistador conversa com algumas pessoas individualmente. A ideia é fazer uma radiografia psicológica do consumidor que revele seus anseios, planos, vazios emocionais, frustrações, detalhes sobre família, profissão. Depois das conversas, os dados são tabulados e divididos em diversos segmentos.

Em 1964, a Almap promove a integração dos departamentos de Mídia, que eram divididos pelos diferentes veículos de comunicação. A coesão de profissionais e setores é cada vez mais utilizada na divisão estrutural das agências, cresce a noção de que o encadeamento de tarefas é a melhor conformação para a 
produção de anúncios. A profissionalização do planejamento de mídia contou com a técnica do GRP (gross rating points). O sistema, desenvolvido pela Nielsen norte-americana $^{69}$, media o somatório das audiências dos comerciais dentro de determinada faixa de programação. A tecnologia possibilitava identificar com precisão o total do público-alvo atingido e a frequência com que isso se verifica, apresentando o somatório das audiências de uma programação em um período (Sant'Anna et at, 2009).

O GRP funcionava da seguinte maneira: se um comercial desse 30 pontos de audiência no Programa Silvio Santos, 20 na novela da TV Globo e mais 20 no Festival de Música da TV Excelsior, o comercial teria ao todo 70 pontos. Os dados eram cruzados pelos publicitários com uma tabela americana para medir o alcance e a frequência média da mensagem nos lares com televisão. Assim, os anunciantes poderiam ter uma estimativa de quanto precisavam investir em mídia para ter uma boa cobertura e resposta do público. Como observa Damante (2006), o surgimento do GRP no Brasil deu destaque ao Mídia como uma voz ativa na tomada de estratégias junto aos clientes. A partir de então, o planejamento dos meios foi apresentado aos clientes pelo Diretor de Mídia e não pelo Contato. A tecnologia incrementou o setor e promoveu uma alteração hierárquica na dinâmica da agência. Ou seja, os procedimentos técnicos provocam, não apenas uma reorganização das atividades rotineiras e cadeias produtivas, como também têm impacto nas configurações de poder dentro das instituições.

A McCann também passou a utilizar o GRP, já que tinha uma pequena parte da conta da Gillette. Com maior orientação técnica para os planos de mídia, a agência era tida como uma escola de propaganda. A criatividade também tomava a dianteira dos negócios, com a contratação de profissionais considerados verdadeiros "artistas". O período era muito favorável e a agência conseguiu dobrar seu faturamento em apenas três anos, com seus nove escritórios espalhados pelas principais capitais brasileiras: São Paulo, Rio de Janeiro, Belo Horizonte, Curitiba, Porto Alegre, Brasília, Recife, Fortaleza, Salvador. Em 1960, o slogan feito para a pasta de dentes Kolynos, "Ah...Kolynos", foi exportado para vários países e é lembrado até hoje (REIS, 1990: 322). Em comemoração aos 25 anos no

${ }^{69}$ Uma das maiores empresas mundiais em pesquisas sobre comportamento do consumidor e medição de audiências. Presente em mais de 100 países, a Nielsen atua em parceria com o Ibope no Brasil. 
Brasil, a agência lançou o livro "Técnica e prática da propaganda", com doze artigos escritos pelos melhores profissionais da empresa (McCann-Erickson, 1962). Os textos tinham o propósito de disponibilizar os "princípios gerais da propaganda segundo a experiência de uma agência no Brasil”, e os direitos autorais foram doados à ABP e à APP (REIS, 1990: 321). Esse livro é mais um mecanismo de legitimação da agência e do próprio campo da publicidade. O livro é um objeto material com grande força simbólica em nossa cultura. Moscovici (2011) considera que o valor social do livro está associado ao conhecimento, ao status e à educação, o que gera sempre discursos nobres e positivos em relação ao artefato. Há ainda o sentido de propagador cultural, componente que transcende o espaço e o tempo, inscrevendo seu conteúdo na história. Desta forma, um livro sobre uma agência de publicidade enobrece a representação social da empresa, garante reconhecimento, prestígio, além de contribuir para a gênese histórica do setor. Assim como uma lei, o livro também funciona como a expressão simbólica de um mundo social.

A era do "boom criativo da propaganda brasileira" também foi incrementada pelos bons resultados da JWT no mercado (PENTEADO, 2004: 113). A nova gestão presidida por Renato Castelo Branco, a partir de 1961, consegue dobrar o faturamento nos seus primeiros cinco anos e conquistar quatro grandes clientes: sabonete Lever, Vick, Nugget e Souza Cruz. O consumo de cigarros estava em alta nos anos 1960, estimulado principalmente pelo cinema e pela publicidade, com mensagens que abandonam de vez qualquer alusão à saúde. As mulheres começam a fumar em massa e o cigarro vira símbolo de sedução e poder. O hábito também se tornou um signo de expressão da liberação da mulher na sociedade. Os fabricantes de cigarro passam a valorizar as tragadas femininas como nunca. Nos filmes, insinuantes gestos de fumar passaram a substituir cenas picantes, associando cigarro ao sexo. As produções Hollywoodianas exibiam suas estrelas fumando, perpetuando o glamour do cigarro por muitos anos (Toaldo, 2005). Mazetti (2014) sublinha que a propaganda estava influenciada pelos movimentos feministas dos anos 1960, e vinculava os cigarros à nova postura da mulher independente, segura e dominante. Ao longo do tempo, o cigarro foi usado inúmeras vezes como insígnia ideológica, ora aparecendo como apropriado, ora como desprezível. Já no final dos anos 1920, como vimos, os eventos americanos conhecidos como "Torches of Freedom" encorajavam o tabagismo feminino, 
representando a emancipação das mulheres e a busca pela igualdade de direitos com os homens. A partir da década de 1990, o cigarro ganha novamente o estigma de "tabu" social, desta vez por estar associado fortemente a doenças fatais.

Desde a década de 1950 já estava mais evidente a ligação entre tabagismo e câncer. Em 1962, o governo inglês anuncia que o cigarro faz mal e grande parte dos riscos à saúde são relatados oficialmente. A indústria lança filtros que, supostamente, tornam o produto menos agressivo e investe em propagandas que realçam hábitos de vida ligados a bem-estar e prestígio social, ignorando as consequências do fumo ao organismo. Marcas de cigarro começam a aparecer em carros de corrida. A narrativa publicitária também procurava cativar os jovens, um consumidor em potencial que, em geral, ainda não se preocupava com futuros danos à saúde (Toaldo, 2005).

Os fabricantes de cigarro tornaram-se grandes anunciantes, e a conta da Souza Cruz fortaleceu a JWT. O novo cliente propiciou o crescimento da agência, que inaugurou escritórios em Porto Alegre, Belo Horizonte e Recife, além de firmar parcerias com agências de Recife, Fortaleza e Belém, expandindo os negócios para fora do eixo Rio-São Paulo. Para elaborar anúncios que expressassem as representações sociais do período, o setor de pesquisas é consolidado para orientar a área criativa e aferir os objetivos da comunicação. No escritório de São Paulo é colocada em prática a técnica das discussões em grupo, a chamada "sala de espelhos" (On Way Mirror), de que a Almap já fazia uso. Para atender principalmente seus clientes de produtos alimentícios e farmacêuticos, a $J W T$ lança no Rio de Janeiro o outdoor de marquise, uma novidade no mercado publicitário. No Departamento de Pesquisas da agência foram usadas diferentes metodologias, como o Dummy Magazine, um rascunho da revista que era distribuído aos consumidores para análise do impacto dos anúncios, o One Air Testing, uma avaliação feita no dia seguinte à exibição de um comercial de televisão e o Painel do Consumidor, que estudava semanalmente hábitos de consumo de 400 famílias (Penteado, 2004).

Na década de 1960 foram criados ainda os departamentos de Promoção de Vendas e o de Relações Públicas nas principais agências brasileiras. Os serviços de $R P$ prestavam consultoria aos clientes em ações ligadas à divulgação midiática das empresas, como lançamento de produtos, coletivas de imprensa, campanhas institucionais, relatórios internos, filme-documentário e reportagens televisivas 
(Penteado, 2004). O trabalho de criação passa a ser acompanhado pelo setor de Atendimento, que estava mais versátil no comando dos intermédios entre o cliente e os diferentes departamentos das agências. Entretanto, os profissionais criativos ainda sofriam com limitações técnicas. Era comum termos apresentações em desenho animado em preto e branco e filmes com animações de fotos, os tabletop, como lembrou Alex Periscinoto, em entrevista para este trabalho.

A maior integração dos diferentes setores de uma agência também transformou a Norton, que ao final da década de 1960 ganha o título de "Agência do Ano" (Abreu; Paula, 2007). A empresa vivia uma fase extremamente favorável nos negócios após a conquista das contas da General Electric, da Nestlé e da Willys Overland do Brasil, uma das mais disputadas concorrências da história, da qual participaram 15 empresas (Abreu; Paula, 2007). Em 1963, inicia seu processo de internacionalização com a formação de uma cadeia de agências, as AALA, Agências Associadas Latino-Americanas, com participação de empresas do México, Argentina, Chile, Colômbia e Uruguai. Para incrementar seu processo produtivo, a empresa priorizou contratar experientes profissionais de criação, acompanhando as transformações de mercado inauguradas pela Almap. O setor de Criação assumia patamar superior dentro da divisão da agência e suas redes de poder. A Norton ficou então conhecida, não só pela boa qualidade dos anúncios, como pela capacidade de transformar a imagem dos clientes. O banco Banespa, por exemplo, conseguiu se desvincular da imagem de instituição fria, formal, distante, para se tornar o "banco do novo tempo", capaz de disputar fatias importantes do mercado (REIS, 1990: 337).

A Norton se torna a primeira agência brasileira a abrir um escritório em Paris, em 1973. A filial trabalhava em parceria com o Grupo Univas, uma das maiores redes de agências da Europa. O acordo operacional sinalizava um estreitamento de relações entre os mercados europeu e brasileiro. A abertura de novos circuitos ampliava não só as possibilidades econômicas do negócio, como também culturais, uma vez que a influência americana era muito presente por aqui. Em Paris, a agência brasileira se aproximou de clientes internacionais e propagou oportunidades de investimento. A conta do Carrefour levou o grupo a montar uma ampla rede de supermercados no Brasil. Depois de dois anos, a sede francesa foi desativada porque a matriz de São Paulo não podia enviar recursos financeiros para o exterior, devido à lei da época (Reis, 1990). 
O profissionalismo conquistado pelas agências nacionais, em larga medida devido ao aprendizado vindo do exterior, começava a destacar características brasileiras que refletiam um pouco mais a realidade do nosso mercado. A confiança de que poderíamos concorrer em iguais condições com os padrões internacionais suscitou um dos momentos mais promissores da publicidade brasileira. Grandes agências que marcariam as próximas décadas foram inauguradas: DPZ, Mauro Salles Propaganda, Proeme, Artplan, DM9. Agências totalmente brasileiras, com mentalidade internacional, que travaram uma verdadeira guerra na conquista de clientes e mudaram a face do nosso mercado mundo afora.

A Proeme é fundada em1962, por Otto Schreb. O ex-diretor da Almap transfere a conta da Volkswagen para a nova empresa. A agência logo se destacou nacionalmente com o slogan "Bom-senso em automóvel", feito para o Fusca (Reis, 1990: 355). Com apenas dois anos de funcionamento, o empreendimento conseguiu contas importantes, como a da CICA, reuniu uma equipe experiente e ficou conhecida como uma das mais criativas do mercado (Reis, 1990).

A Mauro Salles Publicidade foi criada em 1966 com a premissa de que era possível ter no Brasil um padrão internacional de eficiência. O bom momento do mercado foi aproveitado pelo jornalista e radialista Mauro Salles, que deixa o jornal $O$ Globo para dedicar-se ao projeto feito em parceria com seus irmãos. A agência foi montada inicialmente no Hotel Jaraquá, no centro de São Paulo, para atender a conta da Willys Overland do Brasil, uma das cinco maiores montadoras de carro do país. Em apenas um ano de funcionamento, a Salles já estava entre as vinte maiores empresas de publicidade do país. No segundo ano de vida tinha subido para a $11^{\text {a }}$ posição do ranking de agências. Em 1967, fundiu-se com a Inter-Americana, de Armando D'Almeida, inaugurando a Mauro Salles/InterAmericana de Publicidade. O processo de internacionalização foi iniciado em 1969, quando passa a contar com a associação operacional das agências Kenion \& Eckard, dos Estados Unidos e CPV, da Inglaterra. Ford, Texaco, Furnas, Souza Cruz, Brastemp compunham o leque de grandes clientes da empresa. Em 1977, a razão social é novamente alterada para Salles/ Inter-Americana de Publicidade S.A. (Reis, 1990).

A agência que planejou o maior festival de música do mundo, o Rock in Rio, nasce em 1967 no Rio de Janeiro. Fundada como house agency da Veplan 
Imobiliária, a Artplan pretendia unir "arte" e "planejamento". Contribuiu significativamente para o crescimento da Veplan, com mais de 600 lançamentos. Em 1969, Roberto Medina ingressa na agência na direção do setor de RTVC (Rádio, Televisão e Cinema). A conquista de poder gradativo desse departamento foi representada na série Mad Men, quando o personagem Harry Crane, interpretado pelo ator Richard Sommer, inaugura um setor para monitorar a programação de rádio e televisão e melhorar o planejamento das campanhas. Crane cria esse novo papel na agência para conseguir uma promoção. Inicialmente os executivos da Sterling Cooper não deram muita valor para a iniciativa, que ganha importância com o tempo.

A televisão era a grande novidade do período e para onde os publicitários gostavam de produzir anúncios. Medina revolucionou os comerciais da agência com a contratação de diretores de cinema, como Arnaldo Jabor, Bruno Barreto e Carlos Manga. Em 1976 escalou o ator David Niven para o comercial do uísque Passport. Com a presença da celebridade no filme, as vendas aumentaram em 900\%. Logo depois conseguiu a inédita façanha de colocar Frank Sinatra em um comercial de televisão (Neves, 2006). Em 1972, Medina adquire o controle acionário da empresa e em 1974 inicia uma reformulação. O novo presidente cria paralelamente a Artplan Promoções, devido à necessidade de profissionalizar as promoções. A segmentação cada vez maior de departamentos e a ampliação do número de papéis sociais necessários ao negócio denunciam o crescimento e a complexidade que o mercado vinha assumindo no Brasil.

No ano seguinte ao surgimento da Artplan, três iniciais viriam a marcar a história da propaganda brasileira definitivamente: DPZ. Francesc Petit, Ronald Persichetti e José Zaragosa transformaram o escritório de arte Metro 3 em uma das mais prestigiosas agências de publicidade do Brasil, com a adesão de Roberto Dualibi, que atuava como freelancer. O trabalho com comunicação visual já tinha rendido um bom reconhecimento internacional, e o grupo fez do design gráfico seu principal diferencial no mercado. Os primeiros clientes foram dois revendedores Ford (Borda do Campo e CGV), a joalheria H.Stern, Banco Safra, Hotéis Ferrareto, Fotoptica. A criatividade, o bom gosto e acabamentos refinados se tornaram a marca da agência. Os setores de Criação e Planejamento foram montados como os principais da empresa, classificados como os orquestradores do negócio, hierarquizados simbolicamente em patamar superior no jogo de poder 
interno. Em apenas seis meses de vida, a $D P Z$ tinha mais prêmios que todas as outras agências do país. Em 1971, foi considerada a "mais representativa agência latino-americana" pela renomada revista japonesa Idea (Reis, 1990: 358). Em 1980, a publicação Advertising Age a exaltava como "uma das mais criativas de todo o mundo" (REIS, 1990: 358).

O rápido sucesso dessas empresas chama a atenção de empreendedores de fora do eixo Sudeste-Sul, o que contribui para a expansão e consolidação do negócio da publicidade também pelo Nordeste do país, um polo não tão cobiçado pelo mercado empresarial até então. A empresa baiana DM9 merece destaque como uma das mais promissoras do setor. Fundada em Salvador, em 1975, pelo publicitário Duda Mendonça, a agência começou suas atividades com a conta da incorporadora Ciplan. O mercado imobiliário da Bahia estava muito aquecido. Em poucos meses, a DM9 conquistou novos clientes locais e ganhou o título de Agência do Ano Regional, do Prêmio Colunistas. O bom desempenho da corporação atraiu profissionais para Salvador. O mercado amplia possibilidades, não apenas com maior número de divisões internas nas agências e necessidade de novos papéis profissionais, como também geograficamente. A valorização da linguagem regional nas propagandas e o uso de símbolos nacionais tornaram a DM9 conhecida em todo o Brasil. Em 1990, a agência foi comprada por Nizan Guanaes em sociedade com João Augusto Valente, Afonso Serra e o Banco Icatu e inaugura sede em São Paulo (Abreu; Paula, 2007). Um parceiro comercial do porte de um banco de investimentos aponta a força do segmento publicitário na economia e na dinâmica cultural da sociedade. Os bancos são organizações centrais na estrutura capitalista contemporânea, mediam negociações entre mercados globais e filtram grande parte dos lucros e capitais em circulação (Giambiagi et al, 2011).

Novas empresas, respeito internacional, investimento estatal e poderosos clientes privados destacavam a publicidade brasileira em todo o mundo, e afirmavam o profissionalismo do setor. As décadas de 1960 e 1970 proporcionaram a consolidação da propaganda como negócio lucrativo. Os movimentos do campo mostram articulações intrínsecas e alianças entre as agências, como a criação do grupo conhecido como "Sete irmãs", que conseguiu estabelecer uma reserva de mercado extraoficial. De forma sucinta, o período acumulou transformações importantes, como a liderança assumida pelo setor de 
Criação, tanto no processo produtivo, quanto nas redes de poder e disposições administrativas das empresas; o incremento das pesquisas com recursos tecnológicos e aglutinação de saberes externos ao campo; a consolidação de novos papéis sociais que demarcaram adaptações nas cadeias colaborativas das agências e gradativo aprimoramento das funções; a expansão do mercado por outros espaços de comunicação do país; a aproximação de parceiros rentáveis; a aprovação de legislação que regulou padrões e deu autoridade ao segmento; e o nascimento de agências genuinamente brasileiras altamente qualificadas. No início dos anos 1970, as agências nacionais apresentavam desempenho superior ao das multinacionais estrangeiras (Reis, 1990).

Mas tamanho impulso não teria sido possível sem a grande novidade tecnológica e de comunicações do período. A televisão trouxe as condições necessárias para que a publicidade brasileira conquistasse os maiores prêmios internacionais. O veículo despontava como um grande transformador social, abandonando definitivamente sua dependência do rádio e atraindo as principais verbas das agências.

\section{2 - A televisão chega à propaganda}

Os anos 1960 representaram uma virada significativa na história da televisão e na história da publicidade no Brasil. Se o período foi marcado pela explosão da criatividade, o veículo passou a oferecer todas as condições para dar vazão ao potencial criativo das agências. Segundo Armando Sant'Anna, Rocha Junior e Garcia (2009), na televisão os anúncios podiam ser “(...) atrevidos, insinuantes e provocantes (...) " (SANT’ANNA ET AL, 2009: 162). A chegada da tecnologia do videoteipe, processo de gravação de som e imagem em fita magnética, trouxe um impulso profissionalizante e atraiu o interesse da indústria em geral para a produção publicitária de narrativas audiovisuais. O preconceito que o meio sofreu na década anterior, marcada pelo amadorismo dos vexames ao vivo nos programas e na propaganda televisiva, deu lugar a um fascínio criado pela capacidade de comunicação do dispositivo, que tinha o poder de reunir áudio com imagens dentro da casa dos consumidores. A qualidade técnica trazida pelo 
videoteipe provocou alterações nas cadeias produtivas habituais. Os atores, por exemplo, que estavam acostumados a interpretar papéis ao vivo, tinham que refazer suas cenas a cada erro. No início, a classe artística foi contra a tecnologia (Lorêdo, 2000). A adaptação aconteceu paulatinamente, uma vez que as melhorias trazidas para a programação eram inquestionáveis. A tecnologia também gerou uma série de novos cargos e funções nas emissoras (Amorim, 2007). O surgimento do videoteipe desenvolveu outras formas de ação através do ajuste de convenções e agentes em interposição. Tal como nos processos produtivos do mundo artístico, conforme coloca Becker (1977), as renovações de materiais e técnicas trazem novas formas culturais de expressão, de modelos de produção do objeto, e instigam adaptabilidades criativas entre os atores sociais envolvidos no sistema.

A televisão ajudou a estruturar o imaginário desenvolvimentista do Brasil. Renato Ortiz (1988) destaca o investimento do Estado na área das telecomunicações como forma de expandir suas ideologias nacionalistas, principalmente após a tomada do poder pelos militares, em 1964. A integração do mercado e a melhoria das condições técnicas e de distribuição foram diretamente influenciadas pelo aspecto político. A televisão já ensaiava uma audiência significativa, e foi eleita como principal plataforma para a propagação dos ideais governistas. Dominique Wolton (2006) associa a ampliação do acesso a esse bem de consumo à construção de um ideário cultural com forte apelo à modernidade: "A televisão resultou, ao mesmo tempo, num instrumento de propaganda política de influência mais limitada do que pensavam os militares, e também num instrumento de modernização, de identidade nacional, de abertura cultural" (WOLTON, 2006: 154).

De elitizada e distante, a televisão passa a ser a companheira de todas as horas, a referência de comportamento dos brasileiros. Os aparelhos ganharam destaque nos lares e travaram uma relação intimista com o público, que passou a organizar os horários dos afazeres domésticos e a rotina familiar de acordo com a programação das principais emissoras. A produção de televisores pela indústria nacional avançou significativamente, e conseguiu preços mais atraentes do que os importados. $\mathrm{O}$ volume produtivo foi tão grande que a necessidade de importação foi praticamente eliminada já na década seguinte (Carvalho, 2008). O investimento estatal incentivava a ação dos grupos privados, o que resultou em 
ganhos qualitativos e alargamento do acesso ao veículo. Em 1970, a televisão já atingia 56\% da população brasileira (ORTIZ, 1988: 130).

A ideologia nacionalista de sair de uma situação de "atraso" social para o âmbito "moderno" teve nos possíveis usos da televisão um importante aliado. Desde os anos JK, os setores público e privado realizavam amplas intervenções urbanas e na área de telecomunicações, a fim de apoiar a utopia modernista (Ortiz, 1988). Sob o pretexto de difundir a ideologia de segurança nacional, os militares constituíram uma estrutura que permitiu a integração do país por meio de rotas básicas de micro-ondas e adesão a um consórcio internacional para a utilização de satélites, o Intelsat-3. As condições para a formação das redes de televisão foram dadas com a criação da Empresa Brasileira de Telecomunicações (Embratel), a partir de 1965, uma vez que esse empreendimento capacitou os serviços de telecomunicações de longa distância (telefonia, radiodifusão, televisão, telegrafia) com a interligação do Brasil através de linhas de transmissão. Ou seja, o Estado criou um mecanismo que aliou a progressão audiovisual do país à sua interferência, sob o pretexto do desenvolvimentismo. Desta forma, ampliou sua participação, estabelecendo um circuito de dependência entre as emissoras e o setor político.

Com a Embratel começava o movimento das emissoras na direção de unir a programação através das redes. Até então, os programas eram produzidos e distribuídos localmente. A Excelsior foi a primeira a implantar o conceito de rede nacional, a partir de 1963. Ainda não havia a ideia de simultaneidade. Os programas eram gravados e os videoteipes viajavam de um lugar para outro. A Rede Globo é formada em 1969, com a exibição do Jornal Nacional, já que Roberto Marinho queria iniciar sua programação em rede através do jornalismo (Memória Globo, 2005). A Rede Tupi é formada em 1974 com a ligação de 24 emissoras. Tinha como slogan: "Rede Tupi de Televisão: do tamanho do Brasil", e viveu momentos de glória com a exibição de programas como o Clube dos Artistas, Repórter Esso e o Grande Teatro Tupi (Amorim, 2007).

Com as redes, o mercado concretiza as bases para a difusão da ideologia governamental naquele período de ditadura. A programação foi alinhada aos interesses militares, que fiscalizavam com rigor o conteúdo televisivo, sobretudo após a implantação do Ato Institucional $\mathrm{n}^{\mathrm{o}}$ 5, em 13 de dezembro de 1968. O decreto foi o mais duro golpe da ditadura militar, suspendendo as garantias 
constitucionais e dando poderes de exceção aos governantes para punir arbitrariamente qualquer atitude contrária ao regime. Foi um instrumento de intolerância, concentração de poder e ampliação da intervenção em municípios e estados. A medida vigorou até 1978, e produziu um rastro de atitudes autoritárias, como o fechamento do Congresso Nacional até outubro de 1969 (Gaspari, 2014b).

Se os jornais impressos ainda tentavam resistir à pressão, a televisão acatou as diretrizes estatais sem maiores ressalvas. O sistema de concessão pública para a gerência dos canais era prerrogativa do governo. Se alguma emissora desrespeitasse as orientações dos censores, tinha seu sinal cassado, como foi o caso da Excelsior, tirada do ar ao completar dez anos. O Grupo Simonsen, que havia criado a emissora, enfrenta problemas com o regime militar por defender a democracia (Amorim, 2005). A censura à publicidade foi mais branda do que a imposta aos veículos de imprensa. $\mathrm{O}$ controle era feito à distância e não impactou tanto o campo. Por vezes, as agências tinham que submeter seus trabalhos à censura federal em Brasília para que as campanhas fossem aprovadas (Augusto, 2013).

O mercado de televisão se desenvolveu em conexão direta com os poderes políticos. A maioria das emissoras investiu em programas de entretenimento que não espelhavam os conflitos do país. O telejornalismo passou ao largo dos acontecimentos que impactaram a vida pública no período. Para driblar o noticiário nacional, ênfase ao que acontecia no mundo. Os esportes e as novelas aparecem com toda a força e se tornam a principal fonte de publicidade dos canais (Amorim, 2005). Se a repressão às temáticas empobreciam a programação, o aprimoramento técnico fez o setor se desenvolver velozmente.

O artifício dos satélites empregado nas redes também rompeu com a geografia habitual e proporcionou novos limites para o país, reorganizando os sistemas locais. As mudanças tecnológicas que ocorriam em todo o mundo inspiraram o conceito de "aldeia global", cunhado por Marshal McLuhan (2007 [1964]) para mostrar como o aprimoramento dos meios de comunicação e dos transportes estava reduzindo o mundo às mesmas condições de uma pequena aldeia. O autor propôs reflexões sobre a comunicação de massa, a narrativa publicitária, e apontou para a complexidade das relações humanas com as tecnologias. As teorias de McLuhan (2007 [1964]) tiveram destaque internacional e influenciaram diversas áreas, principalmente pela abordagem pioneira a respeito 
da interferência dos meios de comunicação nas sensações humanas. Desde sua primeira publicação, "The Mechanical Bride" (1967 [1951]), a crítica de McLuhan foi alvo de muitas controvérsias. Por um lado, foi aclamado como o "profeta da era eletrônica", por outro foi chamado de "filósofo favorito da Madison Avenue", endereço das principais agências de Nova Iorque (Rocha; Pereira, 2009: 57). A noção de modernidade se alia à noção de cultura de massa, mercado e publicidade. As grandes corporações de mídia, através dos recursos publicitários, ajudaram a estimular desejos urgentes, inefáveis, estimulando o fenômeno do consumo e a produção de identidades culturais baseadas nos reflexos da comunicação global.

A ampliação dos bens de luxo e a introdução de novas tecnologias no ambiente doméstico contribuíam para sensibilizar a população. O governo militar retomou a política desenvolvimentista e as medidas industriais de Juscelino, promovendo um crescimento de nosso parque industrial, de transportes, ampliação do crédito, do mercado interno de bens materiais e de bens culturais (Cardoso, 1978). O Estado se firma como o polo aglutinador da transformação social em muitos segmentos. O período compreendido entre os anos de 1968 e 1973 ficou conhecido popularmente como "milagre econômico", graças às excepcionais taxas de crescimento. O PIB do país teve um salto de $9,8 \%$ para $11 \%$ ao ano, principalmente da indústria automobilística, o que causou dependência do petróleo (Martins Filho, 2011). Conseguiu-se o controle dos gastos públicos, elevação das exportações e das reservas cambiais. Como consequência, tivemos aumento da concentração de renda, da pobreza, da dívida externa, com as importações necessárias ao processo de industrialização e altas taxas de inflação. Esta empreitada desenvolvimentista consolidou a indústria cultural no país, o que provocou uma reorganização social, com liberação dos costumes e a sensação de estarmos inseridos em uma atmosfera mais cosmopolita. As camadas beneficiadas com as políticas estatais “celebravam a era do consumo” (SODRÉ, 1984: 93).

A essa demanda de luxo costumam ajustar-se expressões "consumo moderno" e "moderna sociedade de consumo", "mercado de massa", "sociedade moderna" e outras. E para apoiar a expansão dessa modernidade, os setores privado e estatal passaram a realizar largos investimentos em obras urbanas, telecomunicações, publicidade etc. Neste impulso firmou-se o sistema da televisão. (...) Graças à instituição do crédito direto ao consumidor, as vendas de aparelhos-receptores tiveram um aumento de $48 \%$ em 1968, em relação a 1967, num total de 700 mil 
unidades. (SODRÉ, 1984: 90-91)

Durante o "milagre", cultivava-se um pensamento ufanista, de país do futuro. A euforia nacionalista foi consagrada com a conquista do tricampeonato mundial de futebol em 1970, no México, quando foi criado o slogan: "Brasil, ame-o ou deixe-o" e o hino "Pra frente Brasil". O jingle, que até hoje permanece na memória dos brasileiros, foi resultado de um concurso promovido pela $J W T$. O vencedor foi Miguel Gustavo, que ganhou dez mil cruzeiros, cerca de cem mil reais $^{70}$ (Penteado, 2004). A canção também foi peça importante na divulgação do regime militar.

Com mais espaço e credibilidade na sociedade brasileira, a televisão se torna a principal catalisadora dos recursos publicitários. Em 1967, o meio ficou com $43 \%$ dos investimentos de publicidade, a maior fatia do orçamento de mídia (Penteado, 2004). Dez anos depois, em 1977, a televisão já faturava 55,8\% das verbas de publicidade. Deste montante, a TV Globo ficava com $85 \%$ dos investimentos, a Tupi com $11 \%$ e o restante era distribuído pelos outros canais (Carvalho, 2008).

As agências passam a se preocupar exclusivamente com a produção de comerciais para rádio e televisão, e compram grandes espaços na programação para atender seus clientes. Como a produção de anúncios para estes veículos era mais elaborada, especialmente quando se tratava de filmes, começamos a ter profissionais específicos dentro das grandes agências para atender essa demanda. Os produtores de rádio, televisão e cinema foram acoplados ao Departamento de Criação. Os chamados $R T V C$ são profissionais que executam as ideias da Criação, selecionando fornecedores, negociando orçamentos, escolhendo cenários, contratando atores, cantores ou modelos, enfim, organizando todas as etapas práticas para que o anúncio possa ser materializado. Desta forma, os $R T V C$ estão tão inseridos no processo de criação, que atuam como coautores das peças publicitárias (jingles, spots de rádio, trilhas, comerciais, videoapresentações). A produção de um anúncio envolve uma gama de inventividades, que podem impactar ou mesmo modificar o planejamento inicial. Nas agências de pequeno

\footnotetext{
${ }^{70}$ Valores convertidos através do aplicativo "Conversor de valores", do acervo digital do jornal $O$ Estado de S. Paulo. http://acervo.estadao.com.br
} 
porte esse cargo não existe, os próprios Diretores de Arte ou Diretores de Criação assumem essas funções ou terceirizam (Sant'Anna et al, 2009). Esse novo papel do mundo publicitário ganha força progressivamente e reprograma os esquemas, convenções produtivas e relações cooperativas das agências.

Com a popularidade da televisão também começa a discussão sobre o uso de estratégias de marketing mais elaboradas, como promoção, planejamento, estudo do produto e pesquisas de mercado. As empresas tentavam criar subterfúgios, argumentos em potencial para atingir os mais diversos consumidores. Conhecimentos de marketing foram importados dos Estados Unidos. $\mathrm{O}$ conceito se refere ao entrelaçamento de todas as atividades comerciais que envolvem mercadorias e serviços, desde a produção até o consumo. Ou seja, o marketing irá relacionar os processos e estudos que envolvem criação, comunicação e entrega de bens e serviços ao consumidor final. Neste sentido, as atividades de marketing podem ser correlacionadas com a Teoria da Ação Coletiva (Becker, 1977), uma vez que irão reunir e congregar os diferentes esforços e saberes dentro de uma agência de publicidade. Uma série de etapas precisa ser planejada e executada de forma conjunta por diferentes departamentos, para que os objetivos sejam concretizados. Para que o anúncio seja bem sucedido em sua finalidade de vender algo a alguém será preciso estudar as tendências do mercado, as preferências do consumidor e as formas de distribuição do produto, alinhando-se também com as funções administrativas da empresa (Sant'Anna et al, 2009). Com a integração cada vez maior de diferentes setores dentro das agências, sobretudo com as "duplas de criação", as técnicas de marketing começaram a estimular uma conexão maior entre as várias funções profissionais, estreitando ainda mais redes de interdependência.

As internacionais McCann e JWT foram pioneiras no uso do marketing no Brasil. A JWT empenhou-se na implantação de áreas de pesquisa de mercado, relações públicas e promoção de vendas. As duas agências também começaram a importar filmes em lata para reproduzir aqui modelos de comerciais e programas exibidos no exterior. Houve um processo mais incisivo de americanização da nossa propaganda, já demarcado com a assimilação dos modos de trabalho mais unificados das grandes agências estrangeiras (Gracioso, 1971).

A profissionalização da televisão provoca o ocaso das garotas-propaganda, que reinaram durante toda a década de 1950. As moças que demonstravam as 
qualidades dos produtos ao vivo foram substituídas pelas novas tecnologias. A função se mostrou ultrapassada desde a chegada do videoteipe, uma vez que as modelos apenas liam textos explicativos, sem apelo de vendas, enquanto exibiam carinhosamente os produtos. A publicidade passou a investir em filmes elaborados, gravados e transmitidos com a tecnologia dos satélites e sistemas de micro-ondas.

O aparato televisivo permitiu maior ousadia criativa das agências na elaboração dos comercias, com textos menos didáticos, que se complementavam com o apoio das imagens. Alguns comerciais criados pela JWT seguiam estes preceitos e marcaram a época. A Pepsi se destacou com o slogan: "Tome Pepsi, o sabor pra frente". Para a campanha de lançamento do Sete Vidas, um calçado de borracha da Alpargatas, a agência contratou o jogador de futebol Garrincha e suas sete filhas. Logo depois, o cliente patrocinou o programa A família Trapo, sucesso da TV Record. Em 1967, a JWT criou o jingle "Quando a lâmpada queimar, não adianta estrilar, nem bater o pé; o que resolve é ter logo à mão lâmpadas $G E ”$. A campanha para a marca de jeans US Top também trouxe um jingle que ficou muito popular na televisão: "Liberdade é uma calça velha azul e desbotada", com imagens de jovens embarcando para uma viagem de trem. A letra, criada por Luís Duboc, foi um enorme sucesso e insinuava o sonho de liberdade da juventude em tempos de ditadura. Em 1978, Chico Anysio estrelou uma campanha para as sandálias Havaianas, cujo slogan permaneceu por anos: "Não soltam as tiras, não têm cheiro" (PENTEADO, 2004:114-115).

Alex Periscinoto também costumava trazer rolos de filmes dos Estados Unidos para que os publicitários criativos da Almap pudessem analisar as propagandas televisivas do exterior. Além das ideias ousadas, os americanos caprichavam com edição dinâmica, boa luz e direção. "Víamos trezentos, quatrocentos comerciais num só dia para aprender com o que eles faziam", conta Periscinoto. "Com a análise exaustiva dos comerciais acabei descobrindo que tudo na televisão é pensado, cada segundo, nada está ali por acaso" ${ }^{71}$, finaliza. A propaganda da Almap criada para a Danone fez o iogurte infantil ficar muito conhecido. No filme, um menino imitava sotaque francês e pedia para sua mãe ter Danone sempre na geladeira. Ao invés de falar a palavra "geladeira"

\footnotetext{
${ }^{71}$ Entrevista para a tese.
} 
corretamente, o garoto falava "geladeirra". A pequena brincadeira aumentou as vendas e popularizou a marca. Para Periscinoto, os detalhes são os grandes responsáveis pelo sucesso de um anúncio. O publicitário lembra ainda que a ampla adoção de jingles em comerciais foi um dos diferenciais de nossa propaganda televisiva, uma vez que a maioria dos profissionais do veículo veio do rádio, diferente dos americanos, que "são mais gráficos" 72 . São diferentes aspectos que se firmam como tradições e incutem um imaginário característico de cada campo.

Neste período, mais do que nunca, o governo investia na propaganda de si mesmo, tornando-se o maior anunciante do país. Afinal, o milagre brasileiro precisava ser embasado em eficazes estratégias de comunicação. O Consórcio Brasileiro de Agências de Propaganda formado pelas sete principais agências nacionais, as "Sete irmãs", estabelecia que as companhias de capital 100\% nacional deveriam ser priorizadas pelo governo no atendimento das contas públicas. Com essa articulação informal - entre Standard, Norton, Mauro Salles Publicidade, Denison, Alcântara Machado, MPM, DPZ - as empresas brasileiras só precisavam concorrer entre si. A medida nada mais foi do que a formação de um cartel para diminuir a concorrência de mercado. A publicidade aproveitou a ideologia nacionalista da ditadura militar para conseguir a aprovação desse monopólio, deixando pra trás a hegemonia estrangeira na liderança de mercado. Com a economia em crescimento, os conturbados anos de chumbo acabaram sendo um período de benefícios para o mercado de propaganda, que deixou clara a tendência em priorizar a rentabilidade comercial em relação ao posicionamento ideológico. O setor ganhou poder com a reserva de mercado das "sete irmãs" e também percebeu a força da ação integrada institucional para efetivar seus intentos.

Assim, o campo se uniu para estabelecer métodos de proteção e autogestão. Em 1978, no III Congresso Brasileiro de Propaganda, foi aprovado o "Código de Autorregulamentação Publicitária" para defender a liberdade de expressão comercial e os interesses das partes envolvidas no mercado publicitário, inclusive os direitos do próprio consumidor, mostrando que a publicidade brasileira era madura o suficiente para gerenciar a si própria. Uma comissão com

\footnotetext{
${ }^{72}$ Entrevista para a tese.
} 
representantes dos três setores - agências, anunciantes e veículos - teve a missão de articular o reconhecimento do Código pelo Governo Federal (Augusto, 2013). Quanto mais os padrões publicitários eram legitimados juridicamente, mais o setor gozava de autonomia e poder.

\section{3 - O peso de um Leão de Ouro}

O "milagre econômico" continuava a acelerar o processo de urbanização do país, com uma classe média crescente, que consumia principalmente eletrodomésticos e automóveis. Houve ampliação de cadeias de varejo, como lojas especializadas em bens duráveis e redes de supermercados. A aparência de prosperidade foi o principal motivo pelo qual as camadas médias urbanas se mostraram favoráveis ao regime militar (Ortiz, 1988). As condições econômicas do país atraíram grupos estrangeiros para o negócio da publicidade, como Leo Burnett, Ogilvy \& Mather, Blaise, Young \& Rubicam, GGK, Siboney, Foote, Cone \& Belding (FC\&B), Scali, McCabe e Sloves (Reis, 1990).

Algumas empresas entraram no mercado brasileiro comprando agências nacionais, como foi o caso da gigante Ogilvy \& Mather, que comprou a Standard no final dos anos 1960. O declínio da Standard foi decorrente de disputas administrativas internas. Por volta de 1968, houve um motim no escritório carioca e todos os funcionários saíram da agência levando as contas que atendiam. Assim, seu fundador, Cícero Leuenroth, acabou por entregar o controle acionário da empresa para terceiros. A Ogilvy, que atendia as contas da Shell, General Foods e Kibon, levou a melhor na disputa com a Young \& Rubicam. Em 1972, a agência nacional já tinha sido completamente incorporada pela estrangeira e passou a se chamar Standard, Ogilvy \& Mather (Abreu; Paula: 2007).

A Young \& Rubicam, hoje a maior agência do país ${ }^{73}$, começa a atuar no Brasil em 1973 sem o suporte de uma fusão ou associação a uma marca. Ou seja, independente da boa fase do setor, podemos dizer que o mecanismo de

\footnotetext{
73 Em 2014, a Young \& Rubicam se manteve na liderança do ranking das maiores agências de publicidade brasileiras, segundo levantamento do Ibope Media. Disponível em: http://www.ibopemedia.com/ranking-de-agencias-dezembro-2014/
} 
implantação da empresa foi o mesmo das primeiras agências internacionais que se instalaram por aqui, ainda nos anos 1930. O intercâmbio comercial foi algo consolidado muitas décadas atrás e a ideia de globalização de mercados já estava presente desde o início da formação do campo publicitário no país. A longeva agência americana, fundada em 1923 na Filadélfia por John Orr Young e Raymond Rubicam, chegava a várias partes do mundo para continuar mantendo sua posição de liderança. O escritório sediado em São Paulo conquistou inicialmente as contas da Gradiente, Johnson \& Johnson e Chrysler. Em 1975, a $Y \& R$ comprou parte do controle acionário das agências brasileiras Cosi, Jarbas e Segino Propaganda S.A. Dois anos depois assumia o controle total das ações dessas pequenas empresas, o que ajudou a consolidar a imagem da agência estrangeira no mercado de publicidade nacional (ABAP, 2005).

Leo Burnett foi outra companhia que viu no Brasil uma fonte de novos investimentos. Após adquirir a CIN-Cia. de Incremento de Negócios, a empresa americana instala-se em São Paulo, em 1975. Hoje, a agência de Chicago é uma das maiores e mais premiadas do mundo, com 96 escritórios em 84 países. O ano também marca a chegada da Foote, Cone \& Belding, que consegue o controle acionário da Tempo de Publicidade (Reis, 1990). Ao longo da década de 1980, a $F C \& B$ se funde com outros grupos de comunicação e atualmente é um dos maiores conglomerados de publicidade global, com atuação em 90 países $^{74}$.

Um outro grupo de agências estrangeiras dá início às suas operações no país através de associações com empresas nacionais. A Grey Advertising Inc. se uniu ao Grupo Supergasbrás em 1980 e criou a Universal-Grey Publicidade. A parceria logo foi desfeita, e em 1984 a agência assinou acordou operacional com a $M P M$. A longa trajetória da agência nova iorquina $B B D O$ no Brasil começa em 1975 com a aquisição de $20 \%$ do capital da $C B B A$, que recebe em troca ações da matriz americana. Nos anos 1980, a $B B D O$ desfez esses acordos e se juntou à Lage, Stabel \& Guerreiro como forma de fortalecer sua presença na América Latina. A corporação internacional decidiu ter o controle de pelo menos $50 \%$ das associadas. Ainda em 1975 temos a solidificação do Grupo Interpublic, que incorpora a Proeme (Abreu; Paula, 2007).

$\mathrm{O}$ aumento do interesse externo em nosso mercado de publicidade foi

${ }^{74}$ www.fcb.com 
importante para a valorização da agência como empresa, com divisões e hierarquias que organizavam o caminho da produção, sempre tendo em vista o caráter colaborativo e integrado desta prática para o aparecimento social dos anúncios, nos moldes da Teoria da Ação Coletiva, de Howard Becker (Becker, 1977, 1977a). As novas técnicas de planejamento, pesquisa e posicionamento do produto, multiplicação de ferramentas para avaliação do anúncio e retorno de audiência, levantamentos de concorrência, aumento da produção nacional de televisão e os prêmios internacionais consolidaram definitivamente o trabalho das agências e a percepção social de que a publicidade é um ofício ou um produto cultural elaborado por agências, através de redes colaborativas e cruzadas que se materializam através dessas instituições. O idealismo criativo dos profissionais brasileiros é associado ao compromisso, à técnica e à responsabilidade social de empresas sérias e bem-estruturadas. Se em 1970, segundo o Anuário Brasileiro de Propaganda 76/77, tínhamos a JWT e a McCann nos primeiros lugares do ranking de agências, em 1975 a MPM e a Almap invertem a liderança (Reis, 1990).

O glamour das premiações internacionais só estimulou a capacidade criativa de nossos profissionais. A propaganda brasileira ganhou prestígio, respeito e se equiparou aos mais altos padrões de qualidade mundiais. O publicitário Washington Olivetto, vencedor do primeiro Leão de Ouro brasileiro, considera que os prêmios deram destaque e legitimidade ao nosso campo profissional $^{75}$.

O Festival de Publicidade de Cannes, criado em 1954 pela Screen Advertising World Agencies (SAWA), se tornou o mais importante prêmio da publicidade mundial. O evento, inicialmente realizado na cidade de Veneza, foi criado em decorrência do sucesso do Festival de Cinema de Cannes. O troféu reproduz o Leão de São Marcos, uma das esculturas-símbolo da cidade italiana. Até meados dos anos 1980, Veneza e Cannes se alternavam como sedes do Festival. Os prêmios são divididos em Grand Prix, Leão de Ouro, Leão de Prata e Leão de Bronze. Até o início dos anos 1990 só havia a categoria Filmes, quando novas divisões ampliaram as possibilidades de premiação. O júri é composto por publicitários de vários países. Brasil, Estados Unidos, Inglaterra, Espanha, França e Alemanha foram os mais premiados da história do Festival.

\footnotetext{
${ }^{75}$ Entrevista para a tese.
} 
As premiações são importantes mecanismos de legitimação do campo. A própria opulência do nome em inglês, Cannes Lions International Festival of Creativity, já indica a complexidade do campo e o empenho de seus profissionais em valorizá-lo internamente e frente aos demais setores sociais. Os festivais se tornaram arenas centrais onde ocorrem embates com objetivos de garantir posições elevadas no campo. Os prêmios ganharam tamanha importância que inverteram o sistema de prestígio do setor publicitário. O sucesso das vendas já não é mais suficiente para reconhecer um anúncio como bem-sucedido. É necessário ganhar um prêmio para ser valorizado e aplaudido profissionalmente. O prêmio se transformou em um capital simbólico muito valioso. Ou seja, a própria publicidade criou critérios para se autorreferenciar e garantir sua autonomia. Até se firmar de maneira autônoma, um campo busca se servir de estratégias emprestadas de outros campos (Bourdieu, 1983 [1976]). Inicialmente, buscou referências metodológicas no campo das artes plásticas pela linguagem próxima existente entre esses dois mundos (Abranches; Hoff, 2013). No caso do Festival de Cannes, o campo do cinema ofereceu subsídios para os códigos das premiações publicitárias. Os artifícios de legitimação acionados por um campo são como "imagens" que o grupo cria para a sociedade, recursos para a expressão e dramatização de seu trabalho (Rocha, 1985).

Conquistar um dos prêmios de Cannes se tornou sinônimo de corporação bem-sucedida, as insígnias do evento se transformaram nos melhores cartões de visita para os clientes. O Festival também funciona como um polo de tendências da publicidade mundial. Profissionais e estudantes do mundo todo se encontram e trocam experiências sobre as disposições do mercado. As agências costumam exibir seus troféus em lugares visíveis, em geral logo no hall de entrada, como na sede da DM9 paulista. A primeira conquista brasileira em Cannes foi um Leão de Bronze vencido pela Lince. O filme feito pelos irmãos Ruy e Laerte Agnelli para os amortecedores Cofap fez o nome do Brasil ser pronunciado no pódio mais alto da propaganda em 1970 (Morais, 2005).

Logo depois, a agência repetirá o feito e trará o segundo Leão de Bronze para o Brasil. O comercial premiado foi "Pingo d'água", feito para a fabricante de torneiras Deca. O anúncio foi criado pelo publicitário Washington Olivetto, que na época tinha apenas 19 anos. O filme mostrava uma torneira vista de baixo, de onde caía um pingo por segundo. Cada pingo era filmado em super close e a voz 
em off explicava: “A Deca está lançando a sua torneira com MVS, mecanismo de vedação substituível, que faz com que sua torneira esteja sempre nova. Por isso, a partir de agora, se a sua torneira Deca vazar, é porque você esqueceu de fechar." Neste momento aparecia uma mão que fechava a torneira e sorvia o último pingo. O Leão conquistado em Cannes deu visibilidade a Olivetto e em 1972 ele já era visto como a "revelação da propaganda brasileira" (MORAIS, 2005: 66-67).

O acabamento estético e bem-elaborado dos comerciais de televisão, que começavam a ganhar os maiores prêmios do mercado, se deve muito ao modelo instituído pela $D P Z$. Em menos de cinco anos de vida, a agência já tinha mudado a propaganda brasileira como um todo. A obsessão permanente com a forma elevou o status dos Diretores de Arte, que passaram a ganhar tanto quanto seus parceiros Redatores. Dois dos três sócios da agência, oriunda de um escritório de design, eram artistas plásticos, desenhistas e fotógrafos. Francesc Petit e José Zaragoza impuseram esse rigoroso padrão de qualidade estética e assim se tornaram aclamados Diretores de Arte. Neste sentido, as premiações contribuíram para reordenar cargos, posições, capitais simbólicos, sistemas de prestígio e instaurar disputas correntes nas agências.

A $D P Z$ não só foi responsável por inúmeras propagandas de sucesso, como também quebrou convenções do campo. Tradicionalmente os anúncios eram apresentados aos clientes pelos Contatos. Os Redatores passaram a levar pessoalmente os resultados, com apresentações elaboradas pela própria Criação. Assim, o setor da Criação também participava da parte mais empresarial, burocrática do negócio. Para Olivetto, essas apresentações somam "bom trabalho com bom relacionamento entre agência e cliente. Construindo juntos uma biografia de comunicação do anunciante, sólida e consistente" ${ }^{\text {"76. }}$.

Não demorou muito e a agência conquistou o primeiro Leão de Ouro da propaganda brasileira, em 1974. A ideia surgiu de uma queixa do pai de Washington Olivetto, que havia sido recém-contratado pela $D P Z$ como Redator para formar uma "dupla de criação" com o Diretor de Arte Francesc Petit. O pai de Olivetto acabara de se formar em direito e não conseguia se colocar no mercado porque a maioria dos empregos só oferecia vagas para homens com menos de 40 anos. O filho publicitário fez um levantamento informal e percebeu

\footnotetext{
${ }^{76}$ Entrevista para a tese.
} 
que quase $70 \%$ das ofertas de emprego eram específicas para candidatos abaixo dos quarenta anos. Assim, Olivetto propôs a Petit uma campanha para combater o preconceito. O Conselho Nacional de Propaganda aceitou a ideia e no Dia do Trabalho do ano de 1974 os jornais veicularam uma campanha de utilidade pública, com o seguinte texto: "Homens com mais de 40 anos oferecem seus préstimos profissionais para empresas de pequeno, médio e grande porte. Cartas para rua da Amargura, s/n” (MORAIS, 2005: 126).

A repercussão entre a opinião pública foi imediata. Inúmeras reportagens sobre o assunto foram feitas e um projeto de lei apresentado ao Congresso. No Senado, a Arena fluminense propôs deduções fiscais para as empresas que tivessem pelo menos metade de seus funcionários com mais de quarenta anos. Empresários abriram vagas em suas empresas para funcionários com mais de quarenta anos (Morais, 2005).

Com o sucesso do anúncio para jornal, o tema virou comercial de televisão. O filme em preto e branco começava com o rosto de Ernesto Geisel, então presidente da República, que tinha 68 anos de idade, e seguia com imagens em close de outras personalidades públicas, como o pintor Pablo Picasso, o general Charles De Gaulle, o escritor Jorge Amado, o cantor Frank Sinatra, o ator Charles Chaplin, o físico Albert Einstein, o poeta Pablo Neruda, entre outros. A locução em off dizia:

Você já ouviu falar que um homem depois dos quarenta anos fica ultrapassado? Sem chances de se realizar profissionalmente, se não tiver atingido o ponto máximo da sua carreira até essa idade? Pois bem. Pode ser surpreendente, mas é assim que muita gente pensa. Você não acredita? Então responda: Por que os anúncios classificados de certas empresas levam aquela frase com o preconceito em negrito? Idade máxima: quarenta anos. Ah, você não tem resposta? Mas nós temos. Essas empresas julgam os homens com mais de quarenta anos velhos demais para conseguirem sucesso profissional. E acham normal que eles comemorem o Dia do Trabalho numa fila de desempregados. Mas isso tem que acabar. Nenhum país pode se dar ao luxo de desperdiçar o potencial dos seus homens mais experientes. Empregador: tire dos anúncios classificados da sua empresa aquela frase com o preconceito em negrito: idade máxima quarenta anos. E procure descobrir o talento e a vontade de trabalhar que podem estar escondidos dentro de uma cabeça coberta de cabelos brancos. Lembre-se que todos os homens que você viu aqui começaram a fazer coisas bem depois dos quarenta. (MORAIS, 2005:128)

A publicidade trabalha com o universo do sonho e da idealização em uma 
sociedade adepta ao culto da jovialidade, representação que o próprio setor ajudou a perpetuar (Rocha; Pereira, 2009). Adultos, a partir de uma certa idade, são pouco focalizados pelas mensagens publicitárias. Neste sentido, o anúncio da $D P Z$ contribuiu para ampliar o alvo das narrativas e a percepção social sobre o assunto. Pesquisas realizadas nas décadas de 1970 e 1980 apontam escassa participação de idosos na publicidade e na televisão ou ênfase em características negativas desta faixa etária ${ }^{77}$. A partir dos anos 1990, houve um aumento parcial da presença dessa representação social na mídia. Com o elevação da expectativa de vida no país, a discussão sobre o envelhecimento populacional cresce e esta camada é percebida também por seu potencial de consumo.

O comercial Homem de 40 anos levou o Brasil ao pódio mais alto da Riveira Francesa. Olivetto lembra do prêmio com satisfação:

Fiquei obviamente muito feliz, mas não sinceramente surpreso, porque tinha consciência de que o filme era mesmo muito bom e causaria um burburinho. Sem dúvida foi importante para a minha carreira. Eu, que já possuía alguma visibilidade no meu meio profissional, passei a ser reconhecido em outras áreas o que impulsionou a minha carreira e, principalmente, me proporcionou a possibilidade de ser envolvido num maior número de trabalhos importantes ${ }^{78}$.

A Almap foi a primeira agência brasileira a ter um profissional como jurado no Festival de Cannes, o que trouxe muito prestígio para a empresa. Alex Periscinoto foi convidado a integrar o júri oficial em 1971. Para avaliar os melhores anúncios do mundo, o publicitário assistiu a cinco mil e trezentos filmes selecionados naquele ano. Periscinoto ressalta a importância do Festival para o reconhecimento internacional da publicidade brasileira:

Era um julgamento muito cansativo, ficávamos em uma sala escura vendo filmes das oito da manhã até as sete da noite. Um jurado sentava longe do outro, como uma plateia organizada. E assim, por intermédio do Festival, o mundo começou a prestar atenção nas empresas e nos profissionais de propaganda brasileiros. Nivelamos a propaganda em outro patamar, no patamar internacional ${ }^{79}$.

\footnotetext{
${ }^{77}$ Fonte: www.comciencia.br Reportagem: Mídia expõe imagem negative de idosos. Disponível em: http://www.comciencia.br/reportagens/envelhecimento/texto/env09.htm

${ }^{78}$ Entrevista para a tese.

${ }^{79}$ Entrevista para a tese.
} 
Além da premiação em Cannes, outro importante evento também passou a reconhecer a excelência criativa no campo da propaganda. O Clio Awards foi criado em 1959 por Wallace Ross, que o batizou com o nome de uma das nove musas da mitologia grega. Clio é considerada a deusa da história e da criatividade. A partir de 1965, a solenidade, antes restrita ao mercado norte-americano, começa a avaliar trabalhos internacionais. À medida que outros prêmios surgiam, esse mecanismo ganha ainda mais força como artifício de legitimação para o campo. É importante observar que mercados localizados em diferentes espaços geográficos entram em concorrência para criar suas próprias premiações e se consagrar como dirigentes das tendências e disposições do mundo da publicidade.

O Brasil ganhou seu primeiro Clio Awards em 1976 com um comercial de televisão para o lançamento dos Pneus Tropical, idealizado pela agência Norton (Abreu; Paula: 2007). Em 2001, o comercial "Semana", feito pela W/Brasil para a Revista Época, conquistou o primeiro Grand Prix do Clio Awards. Depois de 42 edições da prestigiada premiação, a agência de Washington Olivetto conseguiu desbancar mais de oito mil peças publicitárias e levar o maior prêmio do Festival com um filme feito para cinema e televisão. $\mathrm{O}$ feito quebrou uma tradição, pois até então o Grand Prix só tinha sido entregue para países anglo-saxões (Morais, 2005). O comercial ressaltava o valor simbólico de uma semana em diferentes contextos, com imagens em preto e branco ilustrando uma narração em off:

\begin{abstract}
Para um preso, menos 7 dias. Para um doente, mais 7 dias. Para os felizes, 7 motivos. Para os tristes, 7 remédios. Para os ricos, 7 jantares. Para os pobres, 7 fomes. Para a esperança, 7 novas manhãs. Para a insônia, 7 longas noites. Para os sozinhos, 7 chances. Para os ausentes, 7 culpas. Para um cachorro, quarenta e nove dias. Para uma mosca, 7 gerações. Para os empresários, $25 \%$ do mês. Para os economistas, 0.019 do ano. Para o pessimista, 7 riscos. Para o otimista, 7 oportunidades. Para a Terra, 7 voltas. Para o pescador, 7 partidas. Para cumprir o prazo, pouco. Para criar o mundo, o suficiente. Para uma gripe, a cura. Para uma rosa, a morte. Para a História, nada. Para a Época, tudo ${ }^{80}$.
\end{abstract}

A consagração dos festivais internacionais, como estratégias que agregam capitais simbólicos importantes ao campo, estimulava a criação de premiações por aqui. A primeira competição profissional do país foi o Festival Brasileiro de Publicidade, idealizado pela Associação Brasileira de Propaganda (ABP). A edição ocorreu no Rio de Janeiro, em 1974, e consagrou o filme "Das lágrimas ao

\footnotetext{
${ }^{80}$ Fonte: www.propagandashistoricas.com.br
} 
sorriso", feito pela $D P Z$ para a fabricante de bebidas Seagram Destilaria Continental. O comercial defendia o consumo responsável de álcool ao mostrar o rosto de um menino com os olhos lacrimosos e uma narração em off dizendo que não havia nada pior para os olhos de uma criança do que ver que seu pai bebeu demais. A mensagem surpreendeu por colocar uma grande indústria de bebidas incentivando o consumo moderado ${ }^{81}$.

Em 1975 é fundado o primeiro Clube de Criação do país, com o nome de Clube de Criação de São Paulo (CCSP). O CCSP foi um desdobramento do Clube dos Diretores de Arte, instituído em 1965, e possuía o objetivo de preservar a memória e valorizar a produção publicitária nacional. A entidade passou a organizar um anuário para selecionar os melhores da propaganda brasileira, nos moldes do Anuário do Clube de Diretores de Nova York. No mesmo ano foi também criado o Clube de Criação do Rio de Janeiro (CCRJ). A partir de 1976, o Festival do Anuário passou a dar destaque às ideias mais criativas dos nossos profissionais, registrando-as em livro. Assim foi editado o primeiro Anuário de Criação do CCSP. Foi a primeira vez que peças de propaganda nacionais foram julgadas por outros profissionais da área e não por jornalistas especializados. $\mathrm{O}$ júri, sempre formado pelos sócios do Clube, elege os trabalhos nas categorias Grand Prix, Ouro, Prata e Bronze $e^{82}$.

Em 1978, a Rede Globo idealiza o prêmio Profissionais do Ano. A emissora já estava consagrada como o canal de comunicação mais influente e poderoso do país. O sucesso das novelas, o requinte do jornalismo que voltava a tratar dos temas factuais com o afrouxamento da censura e a tecnologia usada na cobertura esportiva contribuíam para impulsionar modismos, estilos de vida, hábitos de consumo e ideologias políticas na população. A televisão se tornou o principal meio de entretenimento e informação de grande parte da sociedade (Sodré, 1984).

O Profissionais do Ano foi concebido para consagrar os melhores comerciais exibidos em toda a cadeia de emissoras da Globo, veiculados, tanto nacionalmente, quanto regionalmente. A televisão deu ênfase e projeção à premiação, que se tornou uma das mais importantes e cobiçadas da publicidade nacional. Ser premiado pela maior organização de mídia do país e uma das

\footnotetext{
${ }^{81}$ www.abp.com.br

82 www.clubedecriacao.com.br
} 
maiores do mundo converteu-se em um símbolo expressivo para as agências. A disputa se dá em três categorias: "Mercado", "Campanha" e "Institucional". A primeira celebra o melhor comercial de produto ou serviço, a segunda prestigia o conjunto de comerciais de produto ou serviço assinado por um mesmo anunciante, e a terceira categoria reconhece o comercial ou campanha de propaganda de causa, ideia, instituição ou serviço de utilidade pública desprovido de interesses econômicos, sem apelo de compra ${ }^{83}$. As divisões do prêmio exemplificam a complexidade do campo e a grande diversidade de ramificações construídas ao longo do tempo.

O primeiro vencedor do Profissionais do Ano foi o anúncio do Garoto Bombril, que mais tarde entraria para o Guinness Book, o livro dos recordes ${ }^{84}$, como a campanha que ficou mais tempo no ar em toda a história da publicidade mundial. Os comerciais da marca, criados pela $D P Z$, encantaram as donas de casa por 26 anos. Por unanimidade dos jurados, o Garoto Bombril foi consagrado na categoria "mercado". A campanha, idealizada pela dupla Petit-Washington, foi um fenômeno de comunicação. No final dos anos 1970, a Bombril era uma empresa consolidada, responsável por dois terços da produção mundial de esponjas de lã de aço. O produto fora totalmente incorporado ao cotidiano dos brasileiros, que faziam valer seu slogan “Bombril tem 1001 utilidades". Naquela época, as pessoas costumavam colocar pedaços de Bombril nas antenas de televisão para melhorar o sinal.

Para criar uma campanha para o novo detergente de louças da marca, a agência queria inovar na forma como a publicidade se comunicava com as donas de casa. A maioria dos anúncios mostrava a mulher no papel de esposa servil e mãe dedicada. No entanto, uma intensa mudança comportamental afetava o imaginário feminino. A mulher buscava maior independência dentro e fora de casa. Uso da pílula anticoncepcional, divórcio, conquista de vagas no mercado de trabalho eram questões que rondavam o universo feminino e reposicionavam a representação da mulher na sociedade brasileira. A partir da sutil percepção de que as coisas estavam mudando, a $D P Z$ resolveu investir em um outro perfil para o homem que iria falar com essas mulheres. Para Petit, a propaganda brasileira era muito arrogante, informal, quase uma "falta de respeito" (MORAIS, 2005: 167).

\footnotetext{
${ }^{83}$ www.profissionaisdoano.redeglobo.com.br

${ }^{84}$ www.guinessworldrecords.com
} 
Ao invés de exaltar a virilidade e a força masculina, os publicitários queriam um personagem delicado, tímido e bem-humorado. Uma espécie de antiherói, que se comunicasse com respeito e cordialidade. Em meio a mais de 40 candidatos, o ator Carlos Moreno foi o escolhido para o papel. A ideia do filmeteste era mostrar um jovem químico industrial dos laboratórios Bombril, orgulhoso da empresa em que trabalhava, que tinha que explicar o produto que fabricara, mas morria de vergonha de falar na frente das câmeras. Moreno foi considerado o melhor. A partir daí três comerciais foram gravados para diferentes produtos da Bombril e veiculados na TV Tupi, que oferecia preço mais acessível. A simpatia de Carlos Moreno conquistou o público imediatamente e ele passou a ser chamado nas ruas de Garoto Bombril. Graças ao sucesso que se refletiu nas vendas, os comerciais também foram veiculados na Globo (Morais, 2005).

Em 2004, quando seu contrato acabou, Carlos Moreno tinha gravado 337 comerciais para a empresa. As diferentes campanhas tinham sempre um tom coloquial, conversado e com doses de humor. Os comerciais se tornaram referência de inovação da linguagem publicitária e incentivaram a criação de propagandas mais diretas, simples e com pequenas ironias. Ao responder sobre as razões para o sucesso do personagem, Washington Olivetto é enfático:

\begin{abstract}
Bombril é um daqueles raros fenômenos de uma marca que conseguiu se instalar para sempre na cultura popular de um país. Sinônimo da categoria, Bombril se manteve e se mantém como a mais lembrada, mesmo quando fica muito tempo sem anunciar. O Garoto Bombril lançou e implantou a linguagem definitivamente coloquial na propaganda brasileira. Desde o seu início, teve como característica principal uma linguagem menos impositiva e mais cúmplice. Durou todos estes anos porque foi se atualizando com a própria vida, de onde ele foi tirado. Os 26 anos de sucesso se explicam porque a biografia do personagem foi sempre bem administrada. Trabalhávamos com o seu presente sempre lembrando o seu passado e imaginando o seu futuro. O personagem que nasceu com características só publicitárias passou inclusive a ter algumas características jornalísticas, mas sem nunca perder seu perfil original. Fora isso - graças ao talento do Carlos Moreno - usamos com o mesmo personagem todas as possibilidades que a comunicação oferece. Fizemos coisas humorísticas, racionais, emocionais, musicais, comparativas; enfim, trilhamos todos os caminhos possíveis para seduzir e encantar consumidores ${ }^{85}$.
\end{abstract}

O "baixinho da Kaiser" também foi outro personagem criado pela $D P Z$ que caiu no gosto da população e ainda permanece na memória afetiva de muitos

\footnotetext{
${ }^{85}$ Entrevista para a tese.
} 
brasileiros. O ator José Valien Royo ganhou o papel após apresentar uma coreografia atrapalhada e fora do ritmo do jingle da cerveja, que tinha como tema “A Kaiser é uma grande cerveja, ninguém pode negar" (Zaragoza, 2014). O comercial "Banheiro", que mostrava o baixinho urinando no banheiro conquistou um Leão de Ouro em 1987 e foi apontado pela rede de televisão americana $C B S$ como um dos melhores comerciais de todos os tempos (Abreu; Paula 2007).

Muitos outros prêmios nacionais e internacionais foram criados ao longo das últimas décadas para valorizar e conferir prestígio aos profissionais criativos. Os prêmios em si também se tornaram uma forma de publicidade para o próprio campo da propaganda. Funcionam indiretamente como produtos geradores de repercussão e mídia espontânea para o segmento, atraindo os olhares do mundo inteiro para o setor. Um profissional reverenciado por um julgamento feito por seus próprios pares adquire um capital simbólico importante à sua carreira. As premiações também contribuíram para incrementar a qualidade técnica da publicidade em geral, uma vez que a competição entre as agências se tornou mais visível dentro e fora do Brasil. A produção de anúncios se destacou pela metodologia e capacidade inventiva, o que garantiu reconhecimento externo.

Em resumo, os anos 1970 chegaram ao fim com inúmeras conquistas e transformações que ratificaram a importância da publicidade brasileira. Entre os principais mecanismos de autoridade do campo estão: a Lei $n^{0} 4.680$, que regulou modelos de gestão; as premiações e seus critérios de prestígio; a Criação como força motriz das agências; a chegada de outras empresas internacionais; a qualidade técnica das corporações brasileiras; as inovações tecnológicas na área de pesquisa; os acordos com o governo para estruturação do mercado; a expansão das empresas para outras partes do Brasil; o aumento de parcerias institucionais e fluxo de capitais no setor; e o apelo da televisão como maior plataforma de circulação de conteúdos midiáticos.

No próximo capítulo veremos que a atmosfera de prosperidade dará lugar ao ceticismo gerado por sucessivas crises econômicas, altas taxas de inflação e queda na lucratividade do setor. No período que sucede à redemocratização, o negócio da publicidade conviveu com profundas limitações orçamentárias, baixo nível de consumo e elevada carga tributária. Mesmo assim, o número de agências continuou crescendo e o segmento esboçou um profissionalismo ainda maior, enterrando definitivamente qualquer resquício de amadorismo ou preconceito. 
Empresas enxutas, com atendimento personalizado e ênfase na criação marcaram o padrão das agências. Os executivos da publicidade souberam administrar os momentos difíceis, e alguns partiram para grandes fusões com empresas internacionais.

O século XXI marca a popularização da internet, o que representou uma reorganização do modelo de confecção de anúncios e na organização administrativa e espacial das empresas de propaganda. A internacionalização se impôs como um grande desafio para o setor. Os profissionais da propaganda se viram diante da necessidade de interpretar o mundo virtual e entender o perfil do novo consumidor, que entrelaça suas vivências entre os espaços fragmentados temporal e geograficamente, entre os ambientes on-line e off-line. A troca cultural proporcionada pela globalização e o desenvolvimento tecnológico ocasionaram padrões de comportamento e estilos de vida que ainda estão sendo decodificados pelas agências de todo o país. 


\section{6 - O impacto da internet e o futuro da propaganda}

Popularmente chamada de "década perdida", os anos 1980 trouxeram momentos difíceis para a publicidade do ponto de vista econômico, mas também uma atmosfera de renovação cultivada pela esperança de novos tempos. A estagnação econômica e a recessão causados pela inflação descontrolada e desemprego não inibiram a ação política de uma sociedade que lutava pela volta da democracia. O clima de mudanças também foi acompanhado pelo início do período da informação, com o aparecimento de computadores pessoais, o embrião de uma rede de comunicação mundial e a reorganização empresarial com base na informática. As chamadas Tecnologias da Informação (TICs) lideraram (e ainda lideram) mudanças nas organizações produtivas das agências, nas lutas simbólicas, nas divisões espaciais e criaram novos papéis para o campo. A atração social pelas TICs reordena os hábitos de consumo e as identidades culturais constantemente (Castells, 1999). O campo da publicidade precisou lidar com uma grande variedade de novos fatores, que incluem instrumentos digitais, sistemas financeiros virtuais, canais de distribuição de conteúdo imateriais, mercados personalizados e maior interferência do consumidor na produção.

Desde o fim da década de 1970, o presidente Ernesto Geisel criava condições para o esgotamento do militarismo, a partir de uma abertura "lenta, gradual e segura". A autorregulamentação da publicidade se mostrava um caminho eficaz para colaborar com a política democrática. O Código de Autorregulamentação Publicitária, aprovado em 1978, construiu as bases para a aprovação do Conar, o Conselho Nacional de Autorregulamentação Publicitária. Em 05 de maio de 1980 a entidade foi oficialmente instituída como a primeira organização não governamental do país a zelar por questões éticas relativas a atividades de comunicação (Abreu; Paula, 2007). Com a mobilização social pela descentralização política e direitos à cidadania, ganhava força a ideia de Terceiro Setor, iniciativas privadas de utilidade pública com origem na sociedade civil. Essas organizações sem fins lucrativos são conservadas pela participação voluntária sem vínculos com o setor público e o mercado (Furtado, 2007).

O Conar foi fundado pela Associação Nacional de Jornais (ANJ), Associação Brasileira de Emissoras de Rádio e Televisão (Abert), Associação 
Brasileira de Agências de Propaganda (Abap, hoje Associação Brasileira de Agências de Publicidade), Associação Brasileira de Anunciantes (ABA), Central do Outdoor e Associação Nacional dos Editores de Revistas (Aner) (Abreu; Paula, 2007). O Conselho tomou posicionamento nas relações de consumo e dispôs sobre as responsabilidades das agências, dos anunciantes, dos veículos e sobre o respeito à propriedade intelectual contida nas peças publicitárias. O órgão também passou a estabelecer punições por infração, advertências, correções de anúncios e a verificar o cumprimento das condenações.

O estabelecimento de instrumentos regulatórios é um ponto-chave da organização do campo. Os códigos, conselhos e leis garantem maior autonomia para o setor. Como sublinha Bourdieu (1983 [1976]), quanto maior a autonomia de um campo, menor a sua vulnerabilidade, menores serão as pressões externas sobre ele. Nesse sentido, os organismos de controle são estratégias de conservação de princípios, mantêm a submissão aos limites do campo e ajudam a controlar os antagonismos e conservar a ordem. O próprio campo se organiza para fiscalizar suas condutas e sustentar suas instâncias de consagração. As normas instituídas pelo campo são a concretização de seus sistemas de poder, já que os capitais simbólicos específicos são objetos de competição e disputas (Bourdieu, 1983 [1976]).

O Conar foi uma das grandes conquistas da indústria publicitária brasileira, tornando-se referência internacional. Em 1983, o órgão anuncia o fim da censura prévia aos meios de comunicação. A criação da FENAPRO Federação Nacional das Agências de Propaganda -, em 1982, também ajudou a proteger e solidificar o setor (Augusto, 2013). As entidades civis forneceram parâmetros éticos para o exercício da profissão, de acordo com os princípios construídos pelo próprio campo.

Se as conquistas sociais fortaleciam a ordem democrática, a economia apresentava um quadro bastante preocupante para o país. Com a herança de endividamento deixada pelo "milagre econômico" do período anterior, a inflação média em 1980 passa a ser de $100 \%$ ao ano, e o crescimento econômico atinge índices negativos (Furtado, 2007). Queda nas exportações brasileiras e aumento da taxa de juros no exterior fizeram crescer a dívida externa, o que levou o ministro do planejamento Delfin Neto a recorrer ao Fundo Monetário Internacional para pagar os juros do déficit. Mesmo com a intervenção do FMI, a 
crise continua a se agravar, e em 1983 atingimos uma inflação anual de 211\% (Martins Filho, 2011).

A pressão por eleições vinda de vários setores da sociedade resultou no movimento "Diretas Já", uma enorme campanha pelas eleições presidenciais diretas que contou com a adesão de políticos, intelectuais, artistas, religiosos, além de ampla participação da mídia e de agências de publicidade. Os comícios e passeatas pelas "diretas" reuniram multidões, que clamavam pela redemocratização nas ruas das principais cidades do Brasil. A ementa constitucional apresentada pelo Deputado Dante de Oliveira concretizava a proposta do voto civil. No entanto, a medida foi rejeitada pela Câmara dos Deputados, por não alcançar o número mínimo de votos para sua aprovação. A decisão frustrou a população e causou tumultos no Distrito Federal (Gaspari, 2014d). Em seguida, iniciou-se um período de mudança partidária de muitos políticos, que perceberam que os oficiais não ficariam muito tempo no poder. Apesar da derrota no Congresso, as lideranças do movimento pelas eleições diretas saíram fortalecidas e se tornaram a nova elite política brasileira (Jacob et al, 2010). O lançamento da candidatura de Tancredo Neves, como oposição ao regime militar pela Aliança Democrática, contou com a participação de 19 agências de publicidade, que formaram o chamado "Comitê Nacional de Publicitários Pró-Tancredo Neves" (ABREU; PAULA, 2007:15). Novamente a publicidade se articula para se posicionar ao lado das instâncias de poder. Se durante a ditadura militar o setor foi beneficiado pelo acordo das "sete irmãs", que eliminava a concorrência internacional, no período da redemocratização as agências se organizaram para formar um nova aliança institucional e interferir de perto no jogo político. A própria campanha pelas eleições diretas, largamente insuflada pela mídia em geral, especialmente pela publicidade, já havia sido uma estratégia que envolveu finalidades políticas.

A participação de agências em uma campanha era novidade para o setor do ponto de vista metodológico, uma vez que a legislação eleitoral impedia propaganda política em jornais, rádio e televisão. Ou seja, as empresas de publicidade precisavam atingir a grande plateia de 686 delegados do Colégio Eleitoral sem usar os meios de comunicação tradicionais. Inicialmente o Comitê foi formado por dez empresas, entre as mais importantes do país, como a Denison, Salles/Interamericana, DPZ, CPB, AD/AG, CBBA/PROPEG, MPM, SGB, Exclan 
e Setembro Propaganda (Oliveira, 2003).

Essa associação definiu as bases para a campanha. O uso das cores verde e amarelo e os movimentos corporais como as mãos dadas em uma longa corrente e os braços levantados como um sinal de vitória foram estratégias valorizadas. Cartazes com fotos de Tancredo sorridente destacavam os slogans: "Muda Brasil. Tancredo Presidente." e “Muda Brasil. Tancredo Já.” Outra proposta do Comitê Nacional foi o desenho de um sorriso em azul, com olhos em formato de estrelas ao lado do slogan "Volte a sorrir meu Brasil." O material promocional de campanha, como camisetas, bonés, leques, braçadeiras foi todo confeccionado em verde e amarelo, assim como a decoração dos comitês. $\mathrm{O}$ artifício foi construir uma campanha exaltando o espírito patriota do movimento das "Diretas Já” (Oliveira, 2003). O planejamento das ações publicitárias se concentrava, em sua maioria, em São Paulo. Em eleições indiretas realizadas pelo Colégio Eleitoral, Tancredo Neves e José Sarney conseguiram a vitória pela larga diferença de 480 votos a 180. Depois de 21 anos, o Brasil voltava ao poder civil naquele janeiro de 1985.

Essa grande articulação publicitária, que encarnou a reação civil frente à ditadura militar, foi um dos grandes movimentos de propaganda política já elaborados no Brasil, em um tempo em que o conceito de marketing político ainda não era tão usual na publicidade brasileira. Em geral, os políticos faziam suas campanhas de forma indireta, com a ajuda de um amigo publicitário ou um produtor de televisão que dava alguma orientação, palpite, criava jingles e nada mais (Oliveira, 2003). O momento foi definidor para a entrada oficial das agências de publicidade em futuras campanhas eleitorais. Entre os simbolismos perpetuados pelas ações pró-Tancredo está o do "herói salvador" acoplado à imagem do novo presidente. Tancredo saiu da campanha aclamado pela população como uma espécie de santo (Oliveira, 2003).

A euforia popular em torno da chamada "Nova República" seria abafada pela doença do presidente eleito. Na véspera de sua posse, em 14 de março de 1985, Tancredo foi hospitalizado às pressas. Temendo que a instabilidade de sua saúde fosse usada como pretexto para que os militares não entregassem o poder aos civis, o presidente só anunciou sua doença no dia da posse, 15 de março, quando os chefes de estado já estavam em Brasília para a cerimônia, o que 
dificultaria uma ruptura política. Sarney, seu vice, assume como presidente em exercício, e após 38 dias de muita expectativa, Tancredo morre de infecção generalizada (Almeida, 2002).

Sarney assumiu um país controverso politicamente, amarrado ao legado de Tancredo, e afogado em uma imensa crise econômica. O Plano Cruzado foi a primeira tentativa para desafogar o país. A moeda vigente, o Cruzeiro, foi substituída pelo Cruzado e os salários só seriam reajustados se a inflação chegasse a 20\%. Entre as medidas mais árduas vale destacar a extinção da correção monetária, como forma de tentar compensar a perda de valor da nossa moeda, o congelamento de preços e a criação do seguro-desemprego. Inicialmente, as providências surtiram efeito e o desemprego e a inflação caíram. $\mathrm{O}$ cenário de preços fixos e aparente fortalecimento econômico disparou o consumo. Os comerciantes começaram a esconder as mercadorias para cobrar o ágio, uma espécie de taxa adicional sobre o preço do produto. Em 1986, foi anunciado o Plano Cruzado II, somente após a vitória esmagadora do PMDB nas eleições para governadores, senadores, deputados federais e estaduais. Nesta ocasião, o Distrito Federal elegeu sua representação política pela primeira vez na história. Os eleitos ficaram responsáveis por elaborar a Constituição de 1988 em Assembleia Nacional Constituinte (Almeida, 2002).

O novo projeto econômico provocou disparada nos preços e uma inflação que chegou à casa dos 20\%. Em fevereiro de 1987, Sarney decretou a moratória brasileira. O ministro da Fazenda Dílson Funaro foi substituído por Luís Carlos Bresser Pereira, que apresentou uma solução emergencial para controlar o déficit público. O Plano Bresser congelou os preços e os salários por três meses, cortou os subsídios agrícolas e criou a Unidade de Referência de Preços, URP, para reajuste de salários e obrigações contratuais. Além disso, tributos aumentaram e obras públicas de grande porte foram adiadas. Com isso, o FMI retomou relações com o Brasil e a moratória foi suspensa (Furtado, 2007). Mesmo assim, a inflação não deu trégua e chegou ao espantoso índice de 933\% em 1988 (Martins Filho, 2011). Bresser demite-se e Maílson da Nóbrega assume a Fazenda e institui mais uma tentativa radical de combate ao surto inflacionário. O Plano Verão, criado em junho de 1989, decretou mais um congelamento de preços e a adoção de uma nova moeda: o Cruzado Novo. Sarney terminou seu governo afundado em uma enorme recessão, mas ao mesmo tempo se tornou um protagonista da nova 
democracia brasileira.

Do ponto de vista político, a Constituição de 1988 foi promulgada pelo Congresso e consolidou o direito civil de viver em uma democracia representativa. A Carta defensora dos valores democráticos criou dispositivos para bloquear golpes de estado e assegurou a participação do Poder Judiciário sempre que houvesse lesão ou ameaça aos direitos sociais (Almeida, 2002).

\section{1 - Incertezas econômicas}

O período recessivo da década de 1980 forçou as empresas de publicidade a reduzir custos, enxugar o número de funcionários e buscar soluções administrativas para superar as perdas. O baixo nível de consumo afetou as agências, determinando limitações para os investimentos. A estagnação da economia ocasionou desaceleração no mercado da propaganda. Se no início da década os aportes no campo representavam 2,5\% do PIB, em 1989 caíram significativamente para $0,7 \%$ (Reis, 1990).

Apesar do cenário econômico negativo, os meios de comunicação de massa como jornal, rádio e televisão estavam consolidados como grandes mediadores das relações comunicacionais, e chegavam a praticamente todos os pontos do Brasil. A televisão, especialmente, adquire domínio total do mercado de informações e entretenimento, passando a determinar os temas discutidos coletivamente. Os brasileiros já estavam totalmente acostumados a receber imagens instantâneas do outro lado do planeta, a assistir transmissões ao vivo de eventos esportivos e a incorporar cenas fortes e marcantes ao seu dia a dia. Para Sodré (1984), a televisão construiu um sistema complexo, através do qual os brasileiros processam suas representações sociais. O dispositivo dominou o espaço público de tal forma que se tornou a principal fonte de referência para as identidades e o consumo cultural.

Este sistema produz uma realidade particular, que tende a recobrir todo o espaço social, de maneira análoga à realidade físico-geográfica do território. Quando o sistema é exacerbado (caso americano, por exemplo), a televisão deixa de ser um 
mero reflexo ou extensão da vida social para se tornar o seu próprio código. (SODRÉ, 1984: 34)

Em 1980, chega ao fim a história da primeira emissora de televisão brasileira. Com problemas financeiros, a Rede Tupi de Televisão é cassada pelo governo. Em 1981, entra no ar o SBT, Sistema Brasileiro de Televisão, através de uma concessão outorgada pelo presidente Figueiredo. Com uma programação bem popular, a rede se expandiu rapidamente, com o intenso uso de sorteios e promoções. A emissora de Silvio Santos foi a primeira do mundo a transmitir sua inauguração ao vivo direto do auditório do Ministério das Comunicações. Em 1983 é inaugurada a Rede Manchete de Televisão, pertencente ao Grupo Bloch, com uma programação diferenciada por documentários e programas sofisticados que buscavam uma audiência refinada. A Manchete também se destacou por amplas coberturas do esporte brasileiro e internacional. As redes de TV brasileiras ganharam novo impulso em 1985 com a entrada do Brasilsat, primeiro satélite brasileiro de comunicação. Com ele, o sinal de televisão chegou muito além dos grandes centros (ABAP, 2005).

A prosperidade do meio é alimentada por sua principal moeda de troca: o tempo. O valor dos anúncios publicitários é cobrado pelo tempo de exibição na pequena tela, em geral, 30 ou 60 segundos. Começa uma alta seletividade de anunciantes, principalmente nas emissoras de maior audiência. A consagração da televisão foi um dos fatores que impulsionou o mercado de publicidade a continuar com uma produção relativamente alta no período. A chegada do Brasilsat também permitiu que as agências incorporassem maior número de cidades aos planos de anunciantes de porte nacional (ABAP, 2005).

O agravamento da crise ao longo dos anos 1980 levou o setor publicitário a consolidar o conceito de agência full service, ou seja, empresas que buscam fazer o "serviço completo", atender o cliente em todas as suas necessidades de comunicação, não somente na publicidade. O modelo pretendia ampliar a capacidade de atuação das agências, a fim de solucionar os problemas dos clientes em todas as instâncias, desde a produção de uma campanha, planejamento de marketing, assessoria de imprensa, comunicação interna, realização de eventos ou qualquer outro serviço dessa natureza. Os profissionais da Criação passam a ser ainda mais ativos nas áreas administrativas das empresas para explorar o maior 
número de oportunidades. Esse movimento transforma a organização dos negócios no campo e fortalece uma disputa hierárquica que vinha ganhando força desde os anos 1960. Em algumas companhias, o Diretor de Criação se converte em dono do negócio, como ocorreu na Contemporânea, de Mauro Matos, implantada em 1984. O publicitário lembra que as agências surgidas no período eram montadas a partir da área de Criação ${ }^{86}$.

A grande variedade de serviços de uma agência full service exigiu um esforço integrado das equipes e colocou os agentes produtivos em escalas ainda maiores de interdependência, uma vez que precisaram planejar diferentes estratégias de comunicação que se materializaram de forma conjugada. Neste sentido, é importante sublinhar que o interacionismo em um sistema social apontado por Becker (1977) também está intimamente conectado às alternativas e tecnologias desenvolvidas no tempo em que estão inseridas, e não apenas ao capital simbólico acumulado pelos atores sociais ao longo da história. Embora a cadeia de produção atribua sua funcionalidade e eficiência às regras instituídas por convenções do campo, os novos desafios incitam adaptações ou mesmo reinvenções de acordos. No mundo capitalista, os fatores econômicos são grandes motivadores de quebra ou fim de tratados em ambientes profissionais. A força da economia pode levar, inclusive, à extinção de uma categoria de trabalho. Por isso, mesmo diante da solidez das combinações instituídas em um campo profissional, adaptações são necessárias, a fim de garantir a própria sobrevivência da convenção ou do setor. Os atores sociais que melhor se ajustarem às mudanças constroem novos capitais simbólicos, que podem até se sobrepor aos valores consagrados anteriormente (Becker, 1977, 1986). Em geral, na competição por acumular capitais específicos, os pares se tornam concorrentes (Bourdieu, 1983 [1976]).

A agência full service, também chamada de agência $360^{\circ}$, ou simplesmente agência de comunicação, foi uma proposta para driblar as oscilações da economia brasileira e superar as instabilidades daquele momento. Assim, alguns setores ganharam maior autonomia, o que permitiu descentralização de decisões e otimização do controle de custos e resultados. Muitos clientes, principalmente os de pequeno e médio porte, se sentiram mais confortáveis em contratar apenas uma

\footnotetext{
${ }^{86}$ Entrevista para a tese.
} 
empresa para resolver todos os seus problemas. Houve uma mudança de percepção do campo pelos agentes que gravitam no setor. O contexto social e as dependências externas interferiram nas disposições orquestradas e também criaram oportunidades, novas redes de contato entre os atores sociais envolvidos.

A $M P M$, maior agência de capital 100\% nacional, procurou expandir sua cobertura no país e viu no interior de São Paulo uma boa oportunidade para investimentos naquele início dos anos 1980. A região vivia um bom desenvolvimento econômico, sendo apontada como o segundo maior mercado consumidor do Brasil, e a agência abriu escritórios em Bauru, Ribeirão Preto, São José do Rio Preto e Campinas. A internacionalização também acenava como uma possibilidade cada vez mais concreta. Em 1984, a empresa brasileira fechou acordo operacional com a rede norte-americana Grey. A parceria gerou um intercâmbio de informações e tecnologias, um programa de treinamento de pessoal e o atendimento conjunto de contas importantes, como a da companhia de produtos de higiene Stafford Miller e do grupo de entretenimento Warner Bros. Em 1989, a fabricante de produtos de higiene e beleza Procter \& Gamble chega ao Brasil através da compra da Phebo e a MPM fica responsável por atender parte das contas da gigante global (Augusto, 2013). Expansão de mercados e parcerias, mais uma vez, agregam capital cultural e econômico ao campo. Diretrizes e técnicas trazidas por agentes estrangeiros são muito valorizadas pelo mercado brasileiro, e se convertem em sistemas de prestígio, solidificando a posição de empresas.

Os serviços de assessoria de imprensa, relações públicas e comunicação interna, que funcionavam como departamentos independentes, foram absorvidos pela MPM Press, empresa que atuava de forma autônoma ligada à filial de São Paulo desde o fim de 1987. A área de merchandising também passou a funcionar como divisão, e o setor de promoção foi assumido pela PPR, Profissionais de Propaganda Reunidos, empresa especializada em promoções e merchandising, que teve 50\% das ações compradas pela MPM (Augusto, 2013).

A $P P R$ foi uma segunda marca de agência criada pela $J W T$, em 1980. A ideia inicial era instituir um novo sistema de trabalho unificado, mais ágil e menos burocrático. A experiência levou a JWT a também adotar o padrão full service, objetivando unir esforços dos departamentos de Atendimento, Mídia, Criação e Pesquisa para trabalhar estratégias de marcas para os produtos e serviços do 
cliente. O relançamento do sabonete Lux Luxo foi um exemplo de comunicação mais abrangente. A agência percebeu que a antiga estratégia do produto não acompanhava a mudança da sociedade. A mulher ainda era representada pela beleza impecável, sem obrigações profissionais ou desafios externos ao ambiente doméstico. Ao invés de apenas criar um novo anúncio para a marca, a $J W T$ resolveu repensar toda a proposta da Lever, a fabricante dos sabonetes, que investia no mesmo slogan desde os anos 1930: "Nove entre dez estrelas de cinema usam Lux." Sem abandonar este enredo, a agência reposicionou a imagem do produto com atrizes que representavam a mulher moderna, como Deborah Bloch, Malu Mader, Maitê Proença e Sônia Braga. A empresa também promoveu a fusão do setor de Planejamento com o de Pesquisa, resultando num sistema de duplas, semelhante ao já usado na Criação (Penteado, 2004). É importante ressaltar que no caso das grandes empresas, como JWT e $M P M$, a convergência de atividades não significou necessariamente redução de tamanho do negócio e sim a multiplicação das cadeias produtivas, das conformações e dos papéis sociais. $\mathrm{O}$ modelo full service representou uma nova forma de operacionalizar as disposições em circulação.

A Salles/Inter-Americana comprou $40 \%$ do capital social da ASA Criação de Publicidade, de Belo Horizonte, e começa seu ciclo expansionista no início dos anos 1980. Em 1985, a empresa adquire a UEB Publicidade, uma agência própria do Grupo Ducal, do Rio de Janeiro, e também importa seus profissionais e contas. No ano seguinte, passa a fazer parte do Grupo Salles, formado pela InterAmericana de Publicidade, de São Paulo, pela Merchand-Promoções $e$ Merchandising, do Rio de Janeiro, pela ASA Criação de Publicidade, de Belo Horizonte e pela Synergie Kenyon \& Eckardt, de Paris (Abreu; Paula, 2007). As parcerias e integrações com outras empresas mantiveram a agência em uma situação favorável, estável no posicionamento entre as maiores do país.

O jogo do mercado, agora em tempos de democracia política, colocou a McCann novamente no topo do ranking das agências (Reis, 1990). Durante o período militar, a multinacional tinha sido impedida de concorrer às contas públicas por conta do acordo firmado entre as sete empresas do Consórcio Brasileiro de Agências de Propaganda. O artifício informal determinava que as necessidades de comunicação do governo fossem obrigatoriamente atendidas por companhias de capital nacional. 
Apesar de algumas agências ainda continuarem apresentando cifras financeiras positivas, principalmente aquelas vinculadas às matrizes internacionais, a alta carga tributária do período baixou consideravelmente a rentabilidade do negócio da publicidade como um todo. Mesmo assim, o número de empresas cresceu bastante durante a década. Em 1978 tínhamos cerca de 300 agências em funcionamento, e em 1987 saltamos para duas mil (Reis, 1990). A crise ensinou os publicitários a administrar de perto seu próprio empreendimento. A própria percepção da profissão foi alterada e o publicitário não foi visto como um agente idealista criativo e sim um executivo de negócios, ressalta Lula Vieira $^{87}$.

Se para algumas empresas a solução para evitar perdas foi ampliar as possibilidades de atendimento ao cliente, para outras, a saída significou investir em uma estrutura mais enxuta, com atendimento personalizado e grande ênfase na criação. Muitas companhias se viram obrigadas a dispensar profissionais e a adotar um modelo condensado com a integração de departamentos. Em entrevista para a tese, José Guilherme Vereza enfatizou que a criação continuou centralizando o negócio, e estas agências se formaram em torno de pequenas equipes criativas. Esses empreendimentos se dirigiam a parcelas de mercado que valorizavam mais o produto criativo do que um serviço global. Através de repetidas experiências, o padrão foi crescendo e ganhando força.

Foi justamente para investir em um modelo mais compacto que a empresa suíça $G G K$ chega ao Brasil. Washington Olivetto assume o comando da corporação após sair da $D P Z$, em 1986. Junto com Olivetto, alguns clientes importantes migraram para a nova $W / G G K$, como a Grendene e a Bombril. Estima-se que a perda financeira da agência de Duailibi, Petit e Zaragoza tenha sido de até trinta milhões de dólares (Moarais, 2005).

A sociedade com a $G G K$, avaliada em cinco milhões de dólares, causou muita repercussão no mercado de publicidade. No anúncio público feito para jornalistas em São Paulo, Olivetto ressaltou que, no momento em que a publicidade mundial vendia a ideia da "mega agência", seu projeto estava na direção oposta: “(...) construir uma agência enxuta, mas com mega ideias. Não queremos ser a maior agência do Brasil, apenas a melhor. O que tem que ser

\footnotetext{
${ }^{87}$ Entrevista para a tese.
} 
grande é a ideia, não a agência." (MORAIS, 2005: 242-244). O discurso da criatividade é empenhado para justificar um reposicionamento de mercado. Novamente, a criatividade é reforçada como um mito da profissão, uma aptidão sagrada que tem a força de solucionar todos os problemas do campo.

Em apenas um ano, a $W / G G K$, que só aceitava contas privadas, tornou-se a mais premiada de todo o Brasil. Duas de suas campanhas foram as únicas peças brasileiras escolhidas para o livro Os 100 melhores comerciais do mundo em todos os tempos, de Berenice Kanner (2000). Um deles foi o antológico $O$ primeiro sutiã, escrito pelas redatoras Camila Franco e Rose Ferraz. O comercial conquistou um Leão de Ouro em Cannes, um prêmio Profissionais do Ano e um inesperado título de "melhor filme do mundo", atribuído pela NTV, a Nippon Television, do Japão (Morais, 2005). O filme mostrava uma menina de uns 13 anos de idade no vestiário da escola inibida diante das amigas que trocavam de roupa sem cerimônia, já que usavam sutiã. Ela se esconde atrás da porta para que ninguém a veja. A mãe, percebendo o incômodo, deixa em cima da cama da filha uma caixinha com um sutiã. A menina veste a peça e fica maravilhada. Na cena seguinte, ela caminha com segurança pela rua e chama a atenção de um rapaz. Encabulada, coloca o fichário sobre o busto. Recobrada a confiança, ela volta a andar orgulhosa, quando uma voz em off sentencia o slogan que rodou o planeta: "O primeiro sutiã a gente nunca esquece" (MORAIS, 2005:271). O anúncio reforça a centralidade da cultura material como sustentação dos rituais. O sutiã é colocado como símbolo da passagem da infância para a juventude. O objeto tem o valor de permuta comunicativo, e permite o acesso à condição desejada. Assim, o consumo estabelece transferências de sentido entre sujeitos e objetos, trocas identitárias, padrões de comportamento social (Rocha, 1985).

O comercial Hitler para o jornal Folha de S.Paulo foi a segunda peça da agência brasileira disposta entre as melhores do mundo. $\mathrm{O}$ roteiro de Nizan Guanaes começava com pequeno ponto preto ocupando toda a tela. Aos poucos, a câmera se afastava, deixando claro que se tratava da retícula de uma fotografia. Com o movimento, o rosto de Hitler ia sendo formado por centenas de outros pontos pretos, enquanto uma voz solene declamava o texto:

Este homem pegou uma nação destruída. Recuperou sua economia e devolveu o orgulho ao seu povo. Em seus quatro primeiros anos de governo, o número de 
desempregados caiu de 6 milhões para 900 mil pessoas. Este homem fez o produto interno crescer $102 \%$ e a renda per capta dobrar. Aumentou o lucro das empresas de 175 milhões para 5 bilhões de marcos. E reduziu uma hiperinflação a no máximo $25 \%$ ao ano. Este homem adorava música e pintura. E quando jovem imaginava seguir a carreira artística (Neste momento, a câmera para e o rosto de Hitler fica evidente). É possível contar um monte de mentiras só dizendo a verdade. Por isso, é preciso tomar muito cuidado com a informação e o jornal que você recebe. Folha de S.Paulo, o jornal que mais se compra e o que nunca se vende." (MORAIS, 2005: 279)

A $W / G G K$ aboliu as salas fechadas, ideia copiada de uma agência de Los Angeles. A nova dinâmica espacial foi uma tentativa de romper com as divisões internas e evitar a diluição da informação. Além disso, a função do tráfego também foi extinta, a fim de estreitar o relacionamento entre a área da criação com o atendimento. $\mathrm{O}$ tráfego organiza o fluxo de trabalho desde o pedido inicial do cliente até a execução final pela agência. Cobranças, prazos, levantamento de custos, organização da produção, contratação de terceiros foram atividades aglutinadas aos papéis dos criativos e dos profissionais de atendimento que precisaram trabalhar em maior confluência. O campo define assim novas estratégias para cada agente social. Apesar da reunião cada vez maior de ações em dependência, a oposição entre os setores da Criação e do Atendimento ainda existe, conforme observado nas agências visitadas para este estudo. Zilda Knoploch (1980) registrou a presença desse conflito em sua pesquisa nas agências da década de 1980. A autora analisou que a divisão ideológica entre o setor que cria e o setor que vende sinalizava disputas por maior reputação dentro das estruturas internas que procuravam se repartir em castas, grupos segmentados por suas funções. Nas agências contemporâneas, fica nítido o predomínio hierárquico do Departamento de Criação, visto como o setor que alimenta todos os outros. Neste sentido, há uma inclinação dos demais segmentos em atender suas demandas, uma vez que a integralidade do negócio estaria dependente do talento criativo. O acúmulo de funções do cargo é conjeturado como uma demanda dos novos tempos, marcados por um ritmo intenso e convergências nas transações comerciais, e não como uma perda de autonomia. Mesmo que a Criação assuma um papel que outrora foi desempenhado por outro setor, os profissionais buscam ressignificar a função, a fim de embutir uma nobreza, um prestígio à atividade. Apesar da queda de elementos arquitetônicos, as divisões simbólicas não 
desapareceram.

A equipe de criação da $G G K$ também foi estimulada a apresentar pessoalmente as campanhas aos clientes, padrão que a $D P Z$ já utilizava (Morais, 2005). "Eram espaços abertos sem paredes internas, e as equipes se formam de acordo com o melhor modo de lidar com cada conta, caso a caso. Assim aperfeiçoamos a comunicação entre as áreas e extinguindo a necessidade de um tráfego, afinal era só dar alguns passos", resume Olivetto ${ }^{88}$. A $W / G G K$ também foi a primeira agência do país a informatizar a Criação. As tecnologias acopladas ao processo de criação de anúncios modificaram as formas de atuação e as competências para o desempenho desses papéis, mas consolidaram ainda mais a liderança interna desse setor. Podemos ressaltar também uma relação direta entre espacialidade, competências e hierarquia. Nas agências visitadas, os profissionais da Criação detêm os equipamentos de ponta, ocupam o maior espaço físico e mais centralizado das empresas. "Para se tornar um Diretor de Criação é preciso dominar uma série de habilidades do mundo digital, entender a filosofia dos novos meios de comunicação e suas ferramentas técnicas", resume Otto Pajunk, Diretor de Criação da agência África Rio $^{89}$.

A estrutura enxuta adotada pela $W / G G K$ já estava sendo aplicada na Talent como modelo de negócios. A agência merece relevância como uma das inaugurações mais importantes do período. Criada em 1980, a companhia tornouse em pouco tempo uma das vinte maiores brasileiras, limitando o número de clientes em no máximo dez, com uma taxa de dois novos clientes por ano. Com isso, a personalização e a maior disponibilidade de tempo estariam garantidos no atendimento ao mercado. Calcada no lema "Prestar talento e alugar inteligência", a agência investiu na melhoria da comunicação e desempenho de suas marcas. Com este modelo que privilegiava o relacionamento, a Talent foi considerada a primeira agência do país a fazer propaganda criativa adaptada à crise. A estratégia introduziu o chamado marketing de resultado ou marketing de relacionamento no Brasil. A grande ênfase no planejamento da propaganda gerou maior lucratividade nos negócios em um curto espaço de tempo. A comunicação foi elaborada como um processo contínuo, levando em consideração a segmentação do público-alvo em função do seu valor para a marca e definindo os canais de marketing mais

\footnotetext{
${ }^{88}$ Entrevista para a tese.

${ }^{89}$ Entrevista para a tese.
} 
apropriados, a fim de maximizar o retorno (Reis, 1990).

O critério seletivo de expansão atraiu grandes anunciantes, como Bamerindus Seguros, Grendene, Brastemp, Ford New Holland, Alpargatas, Semp Toshiba. O trabalho diferenciado fez da Talent a Agência do Ano por três vezes consecutivas, em 1984, 1985 e 1986, pelo prêmio Caboré (Abreu; Paula, 2007). A empresa foi responsável por grandes momentos da propaganda brasileira. $\mathrm{O}$ slogan "Não é assim uma Brastemp" foi apropriado como uma fala da cultura popular, amplamente usado no vocabulário cotidiano. Os comerciais de televisão que traziam atores dando depoimentos bem-humorados em um sofá permaneceram por onze anos no ar. O slogan "Nossos japoneses são mais criativos que os outros", criado para a marca de televisores Semp Toshiba, também é considerado um dos mais lembrados da propaganda brasileira. Outra grande campanha da agência foi a da camisaria US Top, cuja frase de efeito virou bordão nas ruas do país: "Bonita camisa, Fernandinho". A frase era dita pelo chefe para um funcionário em uma reunião de executivos, e todos respondiam em coro: "A do senhor também é linda" (ABAP, 2005).

A Contemporânea, de Mauro Matos, Armando Strozenberg e José Antônio Calazans, também priorizou o modelo compacto. A vertente criativa foi a principal orientação dos negócios. Logo depois de sua fundação, a agência ganhou um Leão de Prata em Cannes. O comercial Democracia, feito para o Jornal do Brasil, ficou conhecido por inovar a linguagem da publicidade brasileira. O JB era um dos mais importantes produtos de mídia do país e tinha como slogan: "Um jornal é tão bom como as verdades que ele diz". Para criar o filme de 90 segundos, Mauro Matos mergulhou durante uma semana no departamento de pesquisa do $J B$. Ele conta que pegou inúmeras capas do jornal, espalhou todas sobre a mesa, e observou que suas manchetes resumiam a história recente do país. Separou 14 edições e filmou quadro a quadro, mostrando textos e fotos do processo de redemocratização. Cada página era intercalada por uma das letras da palavra "democracia", com uma trilha sonora que reproduzia os embates entre militares e civis, nas ruas e no Congresso. O comercial terminava com o Hino da República e uma arte que sublinhava a frase que surgia na tela após a palavra "democracia" ser formada: “Abre as páginas sobre nós”. Na assinatura final do Jornal do Brasil, a palavra "jornal" desaparecia e o encerramento destacava a palavra "Brasil", com o acorde final do Hino. O cliente abriu mão de maior tempo de seu nome na tela em 
benefício da ideia. Para Matos, o comercial traduziu o que estava nos corações dos brasileiros, tocou as emoções e trouxe a ideia de que o jornal estava ajudando a construir a democracia ${ }^{90}$.

Podemos observar que a publicidade brasileira passa a ter um caráter mais crítico em conformação às mudanças históricas e de comportamento que vivíamos. Para Goffman (1979), a publicidade se apropria das representações sociais, para que suas mensagens sejam assimiladas e facilmente identificadas pela sociedade. $\mathrm{O}$ autor coloca que a publicidade amplifica e reproduz a cena social, dramatizando assim a realidade (Goffman, 1979).

A retração do mercado transformou os modelos de gerenciamento das agências, com reposicionamentos de funções, de materiais e elementos arquitetônicos. Algumas funções foram extintas e outras ampliadas. A crise também funcionou como polo de oportunidades. As dificuldades financeiras modificaram a própria mentalidade dos agentes sociais envolvidos no campo. Empresas foram planejadas de modo compacto, condensando papéis, o que não significou afastamento de clientes. As agências recém-inauguradas também conseguiram atrair importantes contas, privilegiando a mítica em torno da Criação, que propaga a solução de todas as adversidades do mercado. O período também foi marcado por uma hábil autorregulamentação, especialmente após a instituição do Conar, e o reposicionamento das multinacionais que voltam a competir em igualdade de condições no mercado brasileiro.

\section{2 - Grandes fusões}

O término da Guerra Fria, no fim dos anos 1980, fez o planeta se reorganizar em novas bases geográficas, políticas e econômicas. O socialismo implantado na União Soviética mostrava sinais de fracasso, com intensas manifestações populares, que pediam o fim do partido comunista e clamavam por uma sociedade liberal, baseada na economia de mercado. As reformas do governo de Mikhail Gorbachev, que propunham uma aproximação do sistema capitalista

\footnotetext{
${ }^{90}$ Entrevista para a tese.
} 
com maior liberdade política e autonomia econômica, culminaram na desagregação soviética e na conversão dos países-membros da URSS em estados independentes (Brown, 2007).

$\mathrm{Na}$ antiga Alemanha Socialista, a insurreição civil também ocasionou o colapso do socialismo. Os levantes populares retrataram a crise do sistema e o consequente fortalecimento da economia liberal. A queda do Muro de Berlim, em 1989, e a subsequente reunificação da Alemanha evidenciou simbolicamente a vitória ocidental capitalista. Junto com o Muro, também desmoronava a ideologia socialista. O fim desta divisão mundial estava selado e um modelo mais liberal de governo, alavancado. O movimento de globalização começava a ganhar corpo (Velloso; Martins, 1992).

O processo de abertura econômica no Brasil foi ampliado como resultado de uma política internacional alinhada ao Consenso de Washington, conjunto de medidas para promover o ajuste econômico em países que passavam por dificuldades. Durante a década de 1990, o FMI passou a incentivar a adoção dessas normas, como forma de acelerar o desenvolvimento dos países da América Latina, através da liberalização e abertura para os fluxos de capitais internacionais. O receituário queria ampliar uma visão liberal da economia nos países emergentes, disseminando a abertura comercial, aplicação da economia de mercado e disciplina fiscal. Ao longo dos anos 1990, o Brasil foi um dos países que mais rapidamente praticou os preceitos do Consenso, sobretudo com a política de privatizações de empresas estatais (Velloso; Martins, 1992).

As transformações econômicas eram potencializadas pelo momento político inédito que atravessávamos na Nova República. Pela primeira vez, fomos às urnas eleger de forma direta um presidente civil. A propaganda política que levou Collor ao poder foi baseada no que hoje é chamado marketing pessoal, técnica que passou a nortear as campanhas públicas dali em diante. A estratégia consiste em uma promoção imagética do candidato, como se fosse uma marca, com intensa reprodução midiática, valorização de atributos íntimos, teatralização da política e técnicas de persuasão populares, como jingles e uso de camisetas autopromocionais (Sant'Anna et al, 2009). Collor foi projetado em cima da ideia de modernidade e dinamismo, com uma argumentação que buscou desvincular sua imagem da do governo anterior. O candidato sempre aparecia praticando esportes, lutando karatê, pilotando jatos. O discurso moralizante com o slogan " $O$ 
caçador de marajás" e a espetacularização dos comícios ganharam a simpatia popular. Os chamados "marajás" eram os funcionários públicos beneficiados com altos salários e aposentadorias. A função do marketing pessoal na política é produzir um conjunto de novos significados que contentem os anseios do período e estejam ligados ao imaginário coletivo. $\mathrm{O}$ candidato é um produto feito para satisfazer as necessidades do consumidor; por isso os artifícios usados na propaganda buscam privilegiar a esfera do sonho, da fantasia (Costa, 2004).

Ao tomar posse, Collor lançou imediatamente o Plano Collor de estabilização econômica, idealizado pela equipe da Ministra Zélia Cardoso de Mello. A medida trazia a volta ao Cruzeiro como moeda nacional, congelamento de preços e salários, aumento de tarifas públicas, plano de privatização e o controverso bloqueio das contas correntes e de poupança de toda a população, acima de 50 mil Cruzeiros (Conti, 1999).

Houve uma abertura do mercado, com redução de impostos de importação, o que gerou crescimento de produtos estrangeiros. Com isso, o preço de algumas mercadorias caiu. O governo também incentivou investimentos externos com incentivos fiscais e privatização de empresas estatais. Frente à instabilidade econômica que o Brasil ainda enfrentava, o cenário não atraiu os credores internacionais de imediato. De início, essas medidas geraram efeitos positivos, mas depois contribuíram para aprofundar a recessão econômica, o desemprego e o aumento da inflação (Conti, 1999).

Concomitante ao processo de abertura aos produtos importados entrou em vigor o Código de Defesa do Consumidor, em 1990. O regulamento ajudou a modernizar as relações de consumo no país, com o resguardo do consumidor e a promoção de uma conduta ética dos negócios como um todo. Muitas empresas criaram o SAC, Serviço de Atendimento ao Consumidor, para registrar queixas e providenciar restituições ao público. Este canal de comunicação também estimulou o crescimento do diálogo com o consumidor, através de planos de marketing direto, telemarketing e canais de mídia interativa ${ }^{91}$.

O contexto político foi agravado por contínuas denúncias de corrupção política envolvendo o tesoureiro de Collor, Paulo César Farias, o envolvimento do Ministro da Justiça Bernardo Cabral com a Ministra Zélia Cardoso de Mello,

\footnotetext{
${ }^{91}$ Fonte: Instituto Brasileiro de Defesa do Consumidor: www.idec.org.br
} 
acusações contra a primeira dama Rosane Collor relativas a desvios de verbas da Legião Brasileira de Assistência, a LBA, rombos na Previdência Social e revelações de suborno ao Ministro do Trabalho e Previdência Antônio Rogério Magri (Conti, 1999).

A crise política e a deterioração econômica desencadearam o movimento estudantil dos "caras-pintadas", gigantescas manifestações pelas ruas das principais cidades do país, com o objetivo de pedir a saída do presidente. Por pressão de vários setores da sociedade, como a Ordem dos Advogados do Brasil e a Associação Brasileira de Imprensa, o pedido de impeachment passou na Câmara dos Deputados, o que levou à renúncia de Collor em 29 de dezembro de 1992 (Conti, 1999).

O novo presidente Itamar Franco buscou apoio dos partidos políticos para governar, e procurou atender aos anseios da população. Fernando Henrique Cardoso assumiu a Fazenda e deu início à implementação do Plano Real, programa que estabilizou a economia e acabou com a hiperinflação, sem medidas de choque como congelamentos e confiscos. Houve um fluxo grande de investimentos estrangeiros no país. O sucesso progressivo do Plano Real levou Fernando Henrique à presidência, em 1994, em apenas um turno. Simpatizante das novas medidas liberais para a economia, FHC deu ênfase ao relacionamento com diversos países do globo, principalmente os do Mercosul, investiu na política de privatização e na adoção de uma economia de mercado menos intervencionista (Lamounier; Figueiredo, 2002).

O equilíbrio econômico, a queda da inflação, a abertura aos produtos internacionais, a desestatização de empresas e a aproximação política com outros países estimularam um novo ciclo de internacionalização no setor publicitário. O reconhecimento mundial da nossa propaganda, através dos inúmeros prêmios conquistados nos anos anteriores, também foi um dos principais fatores a atrair grandes grupos de comunicação do exterior para o mercado nacional, a maioria formada pela reunião de diferentes empresas.

Logo no início dos anos 1990, uma notícia deixou o mercado de publicidade surpreso. A $M P M$ fora vendida para a Lintas, concretizando a maior fusão que o mercado nacional de propaganda já tinha visto. Desde meados dos anos 1980, a MPM estudava maneiras de modernizar sua estrutura, já que estava perdendo terreno para agências menores e mais dinâmicas. Além disso, a empresa 
não atendia mais um grande número de contas públicas, desde a mudança no atendimento às contas do governo federal, instituída na redemocratização. A surpresa se deu pelo fato de a agência ter sido vendida para a Lintas e não para a Grey, com quem a MPM mantinha acordo operacional. O negócio foi fechado por 30 milhões de dólares. Dessa fusão nasceu a MPM Lintas, o maior conglomerado brasileiro de publicidade até então. A Lintas fazia parte do Grupo Interpublic desde 1979, corporação que também gerenciava a McCann Erickson e a Lowe \& Partners (Augusto, 2013).

Com as altas taxas de inflação que o Brasil ainda possuía, a Lintas teve dificuldades de administrar as contas pequenas e médias da $M P M$ e fechou todos os escritórios regionais, com exceção de Porto Alegre, São Paulo e Rio de Janeiro. A matriz internacional queria resultados a curto prazo, o que gerou embates na transferência de comando. Muitos clientes abandonaram a empresa poucos meses depois da fusão, evidenciando a má condução do processo de transição. Os atritos eram constantes, principalmente pelas diferenças na cultura empresarial adotada. Os pontos fortes da antiga agência não foram preservados e a fusão se mostrou apenas uma simples sobreposição da Lintas sobre a MPM. Houve demissão de funcionários e nomes importantes pediram afastamento. Para passar a impressão de união integrada, a Criação divulgou os slogans "maior agência da América Latina" e "a maior reunião de talentos numa única agência" (AUGUSTO, 2013: 220). A diferença de valores empresariais é muito comum em procedimentos de fusão.

A recessão de 1991, com Collor na presidência, fez as empresas de publicidade enxugarem ainda mais os custos. As dificuldades administrativas e o período de estagnação tiraram a MPM Lintas da liderança do ranking nacional ao final de 1992. A $D P Z$ assumiu o posto mais alto. Nos anos seguintes, a MPM Lintas caiu ainda mais. Em 1994 o Grupo Interpublic comprou uma pequena rede de agências de Nova Iorque e Londres, a Ammirati \& Plus, e resolveu adotar o nome global de Ammirati Plus Lintas. Quase 40 anos após sua fundação, chegava ao fim a marca $M P M$, uma das agências mais importantes da história da publicidade brasileira (Iribure; Jacks, 2015).

Se para a $M P M$ o processo de fusão provocou o ocaso da empresa, para outras agências a aproximação internacional representou vida longa. Em 1987, a Salles anunciou aporte de capital da Vendex do Brasil, subsidiária do grupo 
holandês de investimentos Vendex, que comprou $40 \%$ da empresa nacional. A associação fortaleceu a agência brasileira que comprou, em 1990, 60\% da GTM \& C, Grupo de Trabalho de Marketing e Comunicação, e partiu para uma integração operacional e jurídica com a Unidade Inter-Americana, da qual já era a maior acionista. Em 1994, a agência inicia sociedade com a D'Arcy Masius Benton \& Bowles e passa a se chamar Salles DMB\&B (Reis, 1990).

A Denison tinha se dividido em duas empresas independentes no fim dos anos 1980: A Denison Propaganda, em São Paulo, e a Denison Rio Comunicação e Marketing Ltda. Depois de algumas tentativas frustradas de reunificação, a Denison Rio passou a integrar o Intergrupo Mercolatino, uma rede de agências da América Latina. A Denison paulista passou a ser gerenciada pelo grupo Bates e passou a se chamar Denison/Bates. Em 1997, essa agência foi comprada pela Standard, Ogilvy \& Mather, uma das empresas do conglomerado WWP e foi chamada de Denison Brasil. No ano seguinte, a Denison Rio é fechada (Castelo Branco et al, 1990).

As fusões e aquisições marcam um intenso processo de globalização da publicidade brasileira. O campo passa a conviver de forma acentuada com novos atores e funções espalhadas por empresas localizadas em diferentes espaços e com rotinas produtivas específicas. O trânsito e a troca cultural entre esses agentes são aprofundados e resultam em novas identidades profissionais e conflitos de poder. As instabilidades também ocasionaram conflitos subjetivos. Os dominantes em cada transação visam a perpetuação da ordem estabelecida com a transmissão de seus habitus para os dominados, o que abre espaço para conflitos internos (Bourdieu, 1983 [1976], 1998 [1989]). O que está em jogo é a capacidade de cada instituição de impor sua cultura empresarial e assim trazer novas definições ao campo. Como o volume de capital econômico das empresas internacionais era superior, a tendência foi de conformação dos parceiros brasileiros, o reconhecimento dos capitais simbólicos externos. Embora esses movimentos comerciais possam significar mais um processo de dominação cultural estrangeira sobre o mercado nacional, vale lembrar que o campo da publicidade no Brasil desde o início se inspirou nos modelos internacionais e se mostrou aberto às suas intervenções.

A ofensiva internacional também atingiu a Norton, que passava por uma boa fase no início da década de 1990, com uma carta de clientes que incluía a 
Bayer, a Parker e a Pan Am. Em 1996, a empresa vendeu 60\% de seu capital ao maior grupo europeu de comunicações, o Publicis, e foi rebatizada como Publicis Norton. Geraldo Alonso Filho, então presidente da agência, assumiu o cargo de representante regional para a América Latina, e iniciou o processo de implantação do grupo europeu no terceiro mundo. Em 2003, o grupo Publicis compra o grupo D’Arcy, controlador da Salles, e dá origem à Publicis Salles Norton (Abreu; Paula, 2007).

A empresa americana $D D B$ Needham, maior agência dos Estados Unidos e quinta maior do mundo, entrou com força no mercado brasileiro. Em 1992, associou-se à $D P Z$, então líder do ranking de agências brasileiras, o que resultou na fundação da primeira filial brasileira da $D D B$. Em 1997, o grupo compra parte das ações da $D M 9$, que passa a se chamar $D M 9 D D B$. O acordo fez com que a $D P Z$ vendesse sua participação de volta para os sócios americanos. A fusão da $D M 9$ com a $D D B$ logo mostrou bons resultados. Ainda em 1997, a $D M 9 D D B$ ficou na terceira posição entre as mais premiadas no Festival de Cannes, e foi a mais premiada do Festival Ibero-Americano de Propaganda, Fiap, e do Anuário do Clube de Criação de São Paulo. Pelos dois anos seguintes, a DM9 se transformou na primeira agência brasileira a conquistar o título de Agência do Ano no Festival de Cannes (ABAP, 2005).

A $D P Z$ continuou seu processo de expansão através da união com a agência argentina Capurro. Em 1996, também se juntou ao grupo Bates, sem venda de ações. Além disso, comprou a agência brasileira Caio Domingues e se integrou à mexicana Zeta Publicidade. As sociedades e aquisições fizeram a $D P Z$ crescer ainda mais. A empresa entrou no mercado de entretenimento com a $D P Z$ Entertainment e diversificou os negócios com duas empresas associadas: a IMK Relações Públicas e a Beautiful People, especializada em contratação de modelos (Abreu; Paula, 2007).

Para acompanhar o movimento de internacionalização que tomava conta do mercado brasileiro, a Almap começou a buscar um sócio estrangeiro desde meados da década de 1980. A corporação queria expandir sua capacidade de atuação e diversificar suas possibilidades de atendimento. Para isso, fundou a $R P V$, uma nova agência especializada em serviços de relações públicas, assessoria de imprensa, marketing político e promoção de vendas. Mas foi somente em 1998 que a empresa fechou negócio com a BBDO Worldwide, transferindo 19,9\% de 
suas ações para o grupo norte-americano, considerado o quarto maior da publicidade dos Estados Unidos. A fusão fez com que a agência brasileira passasse a integrar o grupo Omnicom, controlador da BBDO. A gigante internacional também era muito conhecida por administrar a conta da Pepsi em quase todo o mundo. Logo depois da integração, a nova AlmapBBDO Comunicações Ltda passou a gerenciar a marca de bebidas no Brasil (Abreu; Paula, 2007).

A agência brasileira começou a adotar metodologias da $B B D O$, o que trouxe bons resultados. Um dos recursos aplicados às marcas foi a paridade entre alguns produtos. A paridade ocorre quando um produto não é nem melhor, nem pior que o da concorrência, quando não há diferença real entre marcas da mesma categoria. Por exemplo, todas as canetas possuem a mesma finalidade, assim como todos os cartões de crédito podem oferecer vantagens iguais aos consumidores. Portanto, são produtos com alta paridade. Já os cigarros têm baixa paridade, uma vez que fatores como sabor, tamanho, embalagem os diferenciam imediatamente na opinião do público. Periscinoto, líder da Almap, explicou que a quebra de paridade é a chave para o sucesso de uma marca. A mensagem publicitária é um meio capaz de ultrapassar a paridade das mercadorias, através de estratégias como valorização da imagem da marca e pesquisas de comportamento do consumidor ${ }^{92}$.

Foi assim que a Almap recriou a imagem do picolé Kibon. Uma pesquisa mostrou que sorvete de palito era visto como coisa de criança e os adolescentes tinham vergonha de consumi-lo. A propaganda foi pensada em torno da valorização do jovem saboreando picolés em público. Periscinoto ressalta que a propaganda também é uma forma de proteger o consumidor, legitimando ou ressignificando um hábito cultural ${ }^{93}$. O anúncio para a Kibon trouxe "liberdade" para os jovens consumirem o produto sem constrangimento. A propaganda inverteu a situação e transformou o ato de consumir um picolé em público em uma atitude moderna, descolada, gratificando o jovem com a nova percepção do produto (Periscinoto, 1998).

Da mesma forma, os anúncios de jeans serviram de "passaporte" para a aceitação dessa vestimenta na sociedade. A publicidade ajudou a incorporar

\footnotetext{
92 Entrevista para a tese.

${ }^{93}$ Entrevista para a tese.
} 
culturalmente o jeans ao nosso modo de vestir. Desde festas jovens até ambientes profissionais, o jeans tem livre entrada. Para Periscinoto, não foi a publicidade que criou isso. "A publicidade não dita comportamentos. Ela tira o comportamento do meio da multidão e põe em destaque." (PERISCINOTO, 1998: 100). Como vimos, o famoso slogan da marca US Top "Liberdade é uma velha calça azul e desbotada" traduziu esse ideário nos anos 1970.

Ao contrário da maioria das agências brasileiras que fechavam sociedades com empresas estrangeiras, a $W / G G K$ rompeu com o grupo suíço. Em 1988, dois anos após a inauguração, a empresa já tinha crescido muito e metade do faturamento era destinado à sede exterior. Em 1989, com os bons resultados financeiros, os três sócios brasileiros, Washington Olivetto, Javier Llussá e Gabriel Zellmeister, compraram os 50\% do grupo suíço e fundaram a W/Brasil. A agência, que logo no primeiro ano de vida figurava entre as dez maiores brasileiras, virou tema da música Alô, Alô W/Brasil, lançada por Jorge Ben Jor. O funk, composto após a participação do cantor na festa de fim de ano da empresa, se converteu em um enorme sucesso, responsável pela volta de Ben Jor às paradas musicais (Morais, 2005).

$\mathrm{Na}$ McCann Erickson, o período foi marcado por uma série de aquisições. A partir de 1996 nasce o McCann WorldGroup, um grupo dividido em quatro unidades regionais: América do Norte, Ásia/Pacífico, América Latina e Europa/África/Oriente Médio. O objetivo era atender todas as necessidades de comunicação e marketing de qualquer tipo de cliente. Empresas especializadas em marketing de relacionamento, promoção, internet, área médica, saúde e relações públicas foram agrupadas (ABAP, 2005). Em 2008, o grupo já estava presente em 125 países e apresentou faturamento mundial de 28 bilhões de dólares. A maior negociação da McCann no Brasil se deu em 2011 com a incorporação da W/Brasil. A agência nacional passou a se chamar W/McCannErickson, tendo Washington Olivetto na presidência do Conselho. A alteração do nome da gigante internacional foi uma deferência ao publicitário, muito conhecido internacionalmente. A nova empresa já nasceu como a maior agência de publicidade do Rio de Janeiro, posicionada entre as cinco maiores do país ${ }^{94}$.

\footnotetext{
${ }^{94}$ Fonte: Jornal O Estado de S. Paulo. "McCann negocia compra da W". http://economia.estadao.com.br/noticias/geral,mccann-negocia-compra-da-w,533070
} 
A investida internacional e a retomada de investimentos a partir de meados de 1990 também significaram abertura de novos empreendimentos, cada vez mais sofisticados no atendimento ao anunciante e planejamentos estratégicos. Como exemplo podemos citar as agências Lew' Lara, F/Nazca Saatchi \& Saatchi e Loducca, surgidas nesse período (ABAP, 2005).

Ao fim do século XX, podemos dizer que parte da publicidade brasileira foi desterritorializada, com suas estruturas transformadas face a uma pluralidade de conteúdos que circulam em espaços mundiais. O processo de globalização do setor desencadeou reorganizações das empresas e identidades, com a queda de fronteiras, aproximações comerciais, conhecimento de produtos e códigos culturais produzidos em espaços e tempos distantes. Vimos surgir dimensões que permitem hibridismos, colocam em contato outras culturas, criam outras formas de gerar produtos sociais, fazem brotar comunidades desconectadas do entorno geográfico. No entanto, a internacionalização do mercado não causou um aniquilamento das instâncias locais, que mantiveram seu ritmo e desenvolveram novas formas de articulação com o global. $\mathrm{O}$ aquecimento do mercado proporcionou ampliações de negócios de todos os tamanhos. Paradoxalmente à ideia de total globalizante, ganha ênfase uma autonomia das partes, o fatiamento, a segmentação de elementos, uma multiplicidade maior dentro de um mesmo setor. Hall (2004) defende que a globalização propõe uma nova articulação entre o local e o global. As identidades culturais estão no centro desse processo de interação, racionadas em múltiplas vertentes, tornando-se transitórias e mutáveis.

Uma das comprovações de que o Brasil era respeitado no campo global da publicidade foi a eleição de Mauro Salles, líder da Salles, para a presidência da IAA - Internacional Advertisign Asociation - a mais importante entidade do setor (ABAP, 2005).

Fonte: Jornal do Commercio. "Anunciada fusão entre W/Brasil e McCann-Erickson”. http://www.jcom.com.br/noticia/122374

Fonte: Jornal $O$ Globo. "Washington Olivetto anuncia fusão da W/Brasil com McCann". http://oglobo.globo.com/economia/washington-olivetto-anuncia-fusao-da-wbrasil-com-mccann3018902 


\section{3- On-line/Off-line: novos caminhos da produção de anúncios}

O controle inflacionário, o retorno de investimentos e a expansão internacional não significariam tranquilidade para as agências brasileiras. $O$ tempo dos anúncios feitos à mão, dos layouts em recorte e colagem estava com os dias contados. No novo milênio que chegava, tudo era feito em uma máquina que, na década de 1980, ainda era bastante desconhecida, o computador. A velha prancheta dos layouts estava sendo trocada pelo mouse. A empresa de tecnologia Apple desenvolvia softwares para que um Diretor de Arte pudesse passar seus dias na frente de uma pequena tela. A explosão tecnológica reorganizou a fabricação do conhecimento e apontou para interdisciplinaridades e imaterialidades da produção (Castells, 1999). "Na medida em que áreas diferentes do globo são postas em interconexão umas com as outras, ondas de transformação social atingem virtualmente toda a superfície da terra." (HALL, 2004:15).

$\mathrm{O}$ crescimento dos sistemas virtuais remodelou as relações sociais, o consumo e a produção dos meios de comunicação. Um intrincado sistema de novos significantes e significados emerge a partir destas transformações, potencializadas pelos processos de globalização. Como analisa Marilena Chauí (2006), sob a ação da nova visão econômica liberal, o sistema multimídia acelerou a compressão do espaço e do tempo, estreitando ambientes geográficos e econômicos.

Segmentações, novas formas de criatividade, invenções a partir de reapropriações materiais, traduções, reutilizações de objetos e ideias assentaram realinhamentos nas atividades publicitárias. A criatividade e a noção de cooperação mediada pela informática estariam afetando, não só os ambientes profissionais, mas os modos de ser e estar no mundo, permitindo recortes, tramas, mudanças de lugar, consolidações e apropriações inteiramente repentinas e imprevistas. Tais fragmentações têm impactado diretamente as subjetividades e os estilos de vida (Hall, 2004).

A popularização da World Wide Web, a partir de 1993, possibilitou a criação de sítios de comunicação dinâmicos, de fácil acesso e visualmente interessantes. A partir deste marco, a internet cresceu rapidamente. $\mathrm{O}$ mercado de trabalho passou a operar sob a lógica dos meios digitais, os parâmetros financeiros 
se tornaram universais e as forças políticas tiveram que se reagrupar em blocos que foram muito além das divisões do século anterior (Lazaratto, 2006).

As possibilidades apresentadas pelo ciberespaço se multiplicaram e modificaram a forma como os indivíduos se conectam com o mundo dos negócios e com as expressões culturais. A conjuntura permitiu a incorporação de novos mercados ao sistema econômico internacional, cada vez mais digitalizado. As fusões e aquisições dos anos 1990 em diante no mercado publicitário foram mecanismos diretamente ligados ao processo de globalização da economia mundial, que passou a requerer conglomerados que pudessem responder à expansão dos negócios com mais eficiência e rentabilidade. A estratégia também ocorreu em outros segmentos. A Colgate compra a Anakol e passa a deter $65 \%$ do mercado brasileiro de cremes dentais. A Cica é incorporada pelo grupo Gessy Lever. As duas maiores cervejarias nacionais, Antarctica e Brahma, se unificam e fundam a Ambev (ABAP, 2005). As associações para fortalecer os negócios também foram acompanhadas pelo mercado de moda como um todo, originando grandes holdings ${ }^{95}$. A marca de luxo Louis Vuitton, por exemplo, realizou a fusão com a Moët Hennessy, originando o conglomerado LVMH. A estratégia de crescimento manteve a diferenciação dos produtos e o enfoque em um público elitizado. Em 2008, o grupo torna-se o maior do segmento de luxo do mundo, com faturamento de 2,4 bilhões de dólares (Leite et al, 2009).

A experiência social é marcada por uma expressiva demanda de inovação e imediatismo. O mundo virtual insere os indivíduos em esferas onde as noções históricas tendem a se diluir. O tempo e o espaço se tornaram inapreensíveis. Para Chauí (2006), o tempo se torna intemporal e o espaço um fluxo de imagens, “(...) uma virtualidade real ou uma realidade virtual pressupõe que a distinção entre presença e ausência se reduza a estar presente ou estar ausente na rede ou no sistema multimídia." (CHAUÍ, 2006:72).

O passado retorna ao presente com idas e vindas marcadas por um ambiente descontínuo. Emerge uma percepção de tempo passado como um grande repositório de imagens arquivadas e acessíveis no ambiente on-line. A ideia de temporalidade se volta para o presente, para o viver agora, e a tecnologia se torna orgânica, visceral para a vida no século XXI (Lazaratto, 2006). Junto com ela,

\footnotetext{
${ }^{95}$ Uma holding é uma gestora de participações sociais criada com o objetivo de administrar conglomerados ou grupos de empresas.
} 
todo aparato consumista. Gilles Lipovetsky (2007) caracteriza esse momento como o do "hiperconsumo", e classifica o sujeito contemporâneo como um "turboconsumidor", fazendo ligações estreitas entre tempo e consumo:

\begin{abstract}
Em um ambiente reestruturado pelas novas tecnologias da informação e comunicação, a hipervelocidade, a acessibilidade direta, o imediatismo impõemse como novas exigências temporais (...) Mensagens de texto no celular, foto digital, TV sob demanda, DVD, e-mail: difunde-se o hábito da instantaneidade das trocas e dos resultados, cada um querendo poder comunicar-se e ser contatado, ver e comprar depressa, por toda a parte e a todo momento. A época do "saber esperar", em que a experiência da espera era um elemento de felicidade, recua em favor de uma cultura da impaciência e da satisfação imediata dos desejos. (LIPOVETSKY, 2007:111-112)
\end{abstract}

De acordo com essa premissa estaríamos diante de uma reconfiguração cultural que estaria transformando, em velocidade acelerada, os hábitos individuais e os modos de apreensão dos significados e das práticas de consumo. $\mathrm{O}$ encontro entre bens de consumo e atores sociais se intensifica com as novas configurações de tempo e espaço, que se abrem à multiplicação dos mercados integrados globalmente. A facilidade de acesso ao comércio planetário e o fascínio pelos dispositivos de comunicação, em sua maioria portáteis e conectados à web, acentuaram a mediação tecnológica na vida moderno-contemporânea. Em face dessa multiplicidade, o "local" ganha novo destaque e traz novas formas de articulação com o global. Alguns movimentos mostram que a emergência do local pode ser vista em processos de voltar as atenções para os produtos culturais específicos de cada nação, de revalorizar os componentes particulares de cada povo, região ou etnia (Aucar; Rocha, 2012). As identidades mostram-se no centro desse processo de interação, racionadas em múltiplas vertentes, tornando-se transitórias e mutáveis. Tais identidades podem, inclusive, estar em conflito ou não resolvidas (Hall, 2004).

A pulverização cultural dos novos tempos transformou os modelos da comunicação de massa. Até mesmo a televisão, tradicional canal de comunicação de massa, é desintegrada em nichos cada vez mais específicos. A partir dos anos 1990, a televisão por assinatura começa a transformar os hábitos dos brasileiros, especialmente das classes A e B. Ao final de 1995 já tínhamos 1 milhão de assinantes no país. Globosat, TVA, Multicanal e NET foram as principais 
empresas que consolidaram esse setor (ABAP, 2005). Com a oferta de novos canais, a produção nacional de conteúdo audiovisual foi ampliada. O mercado editorial também incrementou o número de jornais e revistas, com novos títulos destinados a públicos particulares, como a revista feminina Marie Claire ou a revista de celebridades Caras (ABAP, 2005).

A apoteose de fragmentação foi fortemente impulsionada pelas agências de publicidade. Além de poder trabalhar os anúncios em torno de perfis mais elaborados, o que sofisticou as narrativas, o fracionamento do mercado consumidor também significou novas oportunidades de lucros. Os investimentos estavam de volta e, com eles, a concorrência. As grandes indústrias de telecomunicações, implantadas no governo Fernando Henrique Cardoso, se transformaram em poderosos anunciantes. A popularização dos aparelhos celulares deu força a esse segmento e mudou a natureza das interações sociais, conforme sugerem Adriana Braga e Robert Logan (2014). Os autores consideram o telefone móvel um dispositivo protético, que traz uma série de funções e serviços, um aglomerado de comunicação móvel que aciona outras indústrias emergentes, como a de aplicativos e gadgets eletrônicos. Segundo dados da Anatel, no final de 2015, o Brasil possuía 269,59 milhões de aparelhos celulares ${ }^{96}$. O setor de automóveis também cresceu significativamente, com a entrada de marcas como Peugeot, Renault, Citröen, Audi, Mitsubishi, Nissan, Land Rover, Honda e Toyota (ABAP, 2005). As agências protagonizaram essa retomada econômica ao reposicionar as marcas em fatias específicas de mercado.

Em 1997, o Governo Federal redefine as regras para a remuneração das agências de propaganda no país com a promulgação do Decreto $n^{0} 2.262$. Como consequência do incentivo ao livre mercado, a medida desregulamentou a antiga Lei $n^{0} 4.680$, que fixava em $20 \%$ a comissão paga às agências ${ }^{97}$. Na prática, para conquistar ou manter os clientes, as agências já aceitavam receber comissões bem abaixo do decreto. Ou seja, havia uma evidente dissonância entre a Lei $n^{\circ} 4.680$ e a prática do mercado. A nova medida abriu espaço para a livre negociação, o que fragilizou as agências e facilitou a entrada dos bureaux de mídia no país. Os bureaux são empresas que funcionam como intermediários na compra de mídia.

\footnotetext{
${ }^{96}$ Fonte: www.anatel.gov.br - http://www.anatel.gov.br/dados/index.php/destaque-1/283-movelacessos-maio

${ }^{97}$ Disponível em: http://www.planalto.gov.br/ccivil_03/decreto/Antigos/D2262.htm
} 
Em geral, adquirem espaços publicitários em grande quantidade a preços baixos e depois os revendem para agências e anunciantes a preços mais altos, prática conhecida como overprice. Muitos anunciantes internacionais trabalhavam com esse tipo de empresa e queriam repetir o modelo no mercado brasileiro. As pressões externas travaram duras disputadas no campo. Nesse sentido, a globalização provou uma redução das proteções nacionais instituídas ao setor, que se mobilizou para recuperar a estrutura da permanência. Como detecta Bourdieu (1983 [1976]), frente a uma ameaça, as lideranças de um campo se esforçam para manter a estabilidade conquistada.

Para combater a entrada dos bureaux e equilibrar forças entre anunciantes, agências e veículos, foi elaborado o CENP, Conselho Executivo das NormasPadrão. O órgão definiu práticas éticas e comerciais que deveriam sempre ser observadas por todos os segmentos envolvidos na negociação publicitária. O código fixou em $20 \%$ as comissões das agências para veiculação de até 2,5 milhões de reais e permitiu descontos maiores para verbas acima desse valor, podendo chegar até $15 \%$. O CENP trouxe um novo parâmetro para as relações comerciais, uma vez que contemplava outras formas de remuneração e fiscalizava as transações em exercício. Depois de muitas articulações com líderes do setor, as Normas-Padrão foram enfim aprovadas em 2001, representando um marco para o segmento (Augusto, 2013). O campo se repensa e encontra caminhos para a institucionalização e medidas de proteção para suas próprias regras, o que assegura maior autossuficiência.

A desregulamentação também foi um símbolo de que as regras do século anterior estavam ultrapassadas e um novo jeito de fazer publicidade nascia com o milênio. A internacionalização derrubou as fronteiras e limites geográficos do campo. No ano 2000, a Almap/BBDO foi eleita a Agência do Ano no Festival de Cannes. O feito seria repetido pela $F / N a z c a S \& S$ no ano seguinte (ABAP, 2005). As tecnologias da informação e seus suportes deflagraram o surgimento de outros papéis e estratégias de ação publicitárias. As agências precisaram criar planos para divulgar produtos e serviços em espaços com linguagens, custos e relações de consumo inteiramente novas. As redes sociais, por exemplo, abriram espaço para uma comunicação personalizada, necessidade de atualização constante, consumo individualizado e participativo. Tais inovações mudaram a dinâmica das agências e as identidades profissionais. Diante do desconhecido, aprendizados, 
socializações, usos de técnicas, deslocamentos no modelo são executados para que não seja necessário revolucionar a economia do conjunto (Becker, 1977). Becker (1977) ressalta que é importante privilegiar o cenário da descoberta, pois representa, muitas vezes, uma oportunidade de sair da rotina. O novo só é estranho porque ainda não foi decodificado.

O campo aciona então novos agentes sociais para a organizar suas dinâmicas de atuação e a produção on-line. Os jovens foram encarados como hábeis articuladores do saber digital. Como detectam Rocha e Pereira (2009), na virada para o século XXI, houve um resgate da força juvenil com o avanço da tecnologia que caminha lado a lado com as novas gerações. A comunicação tecnológica, sobretudo em forma de gadgets eletrônicos, é marca do jovem contemporâneo, que demonstra familiaridade com a cultura digital e facilidade de trânsito nos ambientes on-line (Rocha; Pereira, 2009). As agências abriram maiores oportunidades para jovens recém-formados. O Diretor de Criação Otto Pajunk, da África Rio, tem apenas 27 anos e lidera alguns processos de produção dessa importante empresa. Em entrevista, enfatizou que algumas campanhas são produzidas apenas para o mercado digital, procurando potencializar as características de cada meio e os materiais em circulação.

\footnotetext{
Você tem que saber utilizar as ferramentas e as vantagens e desvantagens de cada uma para otimizar a criação da melhor forma. $\mathrm{O}$ grande segredo do publicitário daqui para frente é isso. Você tem cada vez mais plataformas, cada vez mais ferramentas e o segredo é saber utilizar cada uma da melhor forma possível ${ }^{98}$.
}

A internet irá renovar as convenções do campo da publicidade como um todo. Inovação e atualização se tornam palavras recorrentes nos círculos corporativos. Outros capitais simbólicos entraram em circulação e desativaram antigas convenções. Nesse período, algumas agências passaram por processos de sucessão nas cadeias de comando para novas gerações, como foi o caso da Almap, que liderou importantes transformações do setor de Criação nos anos 1960. Em 1998, Alex Periscinoto deixa a empresa para seus "sucessores", Marcelo Serpa e José Luis Madeira. A transição foi considerada por jornalistas do setor como "o

\footnotetext{
${ }^{98}$ Entrevista para a tese.
} 
mais bem-sucedido case brasileiro de sucessão profissional em agências" ${ }^{99}$. A empresa, que havia passado por crises de mercado e liderança nos anos 1990, se reposicionou e atravessou seu melhor período. Em 2003 foi considerada a melhor agência do mundo no Festival de Cannes, e em 2004 conquista o inédito título de agência mais premiada do mundo pelo The Gunn Report, ranking dos mais importantes prêmios internacionais (Abreu; Paula: 2007).

Ainda na década de 1990, a JWT, DM9 e Almap começam a desenvolver campanhas na internet. Naquele momento, as agências ainda não tinham um conhecimento mais apurado das linguagens e potencialidades da nova mídia. Desta forma, o espaço publicitário na web foi praticamente uma reprodução das práticas usadas nos veículos convencionais. A empresa de tecnologia interativa Midialog passa a expandir sistemas de automação e códigos multimídia que são adotados por grandes empresas de comunicação, como F/Nazca, McCann Ericsson, Lew' Lara, DM9, MPM, Lintas, JWT, além das redes de televisão Globo e SBT. Em 1999, o Grupo Ibope, um dos acionistas majoritários da Midialog, divide o empreendimento para criar uma nova empresa, a MidiaClick, uma agência para concentrar as atividades criativas e ações de interatividade on-line ${ }^{100}$. A nova corporação investiu na contratação de publicitários da área de Criação como forma de ampliar sua atuação no mercado. Logo de início, os sócios mudaram o nome para AgênciaClick, com o intuito de desfazer a imagem de empresa de software. A AgênciaClick foi a primeira agência brasileira especializada em internet ${ }^{101}$.

$\mathrm{Na}$ mesma época, a Publicis e a Norton criaram a InterNort, uma produtora on-line. Outras agências, como W/Brasil e McCann também começam a utilizar a internet para veicular publicidade. A F/Nazca abriu uma divisão voltada para a rede, a AdverSiting, assim como a Young \& Rubicam. A partir dos anos 2000, as empresas também criaram seus próprios sítios de comunicação, com portfólios on-line (Abreu; Paula, 2007).

\footnotetext{
${ }^{99}$ Fonte: Meio e Mensagem. - Disponível em: http://www.meioemensagem.com.br/home/comunicacao/noticias/2013/06/03/Serpa-e-Madeira-20anos-de-Almap.html

100 Fonte: ABAP-MG: www.abap-mg.com.br. Disponível em: http://www.abap$\mathrm{mg}$.com.br/abap/blog-de-noticias.aspx ?id=298

${ }^{101}$ Em 2014, a AgênciaClick mudou o nome para Isobar Brasil, como parte da consolidação no país da agência de comunicação global Dentsu Aegis Network, dona da Isobar. www.isobar.com
} 
Em 2002, o recém-eleito presidente Lula assina uma Emenda Constitucional que abre formalmente a entrada do capital estrangeiro no setor de mídia do Brasil. A determinação foi apoiada pela Associação Nacional de Jornais, ANJ, Associação Brasileira de Emissoras de Rádio e Televisão, Abert, e pela Associação Nacional de Editores de Revistas, Aner. Grupos estrangeiros puderam adquirir até $30 \%$ do capital total das empresas nacionais. Os outros $70 \%$ permaneceriam sob controle de brasileiros ${ }^{102}$. A medida foi importante e necessária, uma vez que a globalização alargava as ramificações e possibilidades de articulação em múltiplas divisões de negócios.

Novos grupos de comunicação são consolidados, como a holding Ypicomposto pela $D M 9 D D B$ e pela recém-lançada África. A Ypi era especializada em investimentos em agências e serviços de comunicação. A $D P Z$ também se associa à empresa japonesa Dentsu para operações na América Latina, com foco na Argentina. Conglomerados internacionais seguem crescendo, como foi o caso da Fallon, que se integra à $P M A$ e dá origem à Fallon/PMA e da $B B H$, que se junta à Neogama. O grupo Brasil Mídia Exterior, criado em 2001, adquire uma série de empresas do setor, assim como o Clear Channel, que compra o Grupo L\&C. Também tivemos a chegada da corporação europeia JC Decaux (ABAP, 2005). Por força das tecnologias da informação, das novas configurações de tempo e espaço e da facilidade de circulação do capital econômico, os processos de associação de empresas continuam a impactar o setor da publicidade, mostrando a potência da globalização na organização do campo.

Em 2001 foi criado o Grupo $A B C$ de comunicação e marketing, uma parceria entre os publicitários Nizan Guanaes, Guga Valente e o banco Icatu como sócio investidor. Novamente vemos instituições com forte poderio econômico se inserindo no campo da publicidade. Inicialmente o Grupo $A B C$ agrupou quatro agências: DM9DDB, África, MPM e Loducca. Depois, expandiuse para empresas com operações especializadas, marketing direto e marketing de ponto de venda. Em 2008, foi aberta a primeira agência fora do Brasil, a Pereira \& O’Dell, em São Francisco, na Califórnia. Em 2010, a Africa Global foi inaugurada em Nova Iorque, que em 2013 associou-se à empresa Kinea Investimentos. Atualmente a corporação conta com dezesseis empresas: bferraz,

\footnotetext{
${ }^{102}$ Disponível em: http://www.planalto.gov.br/ccivil_03/constituicao/emendas/emc/emc36.htm
} 
DM9, África, CDN, Interbrand, Morya, NewStyle, MindDigital, Escala, Pereira \& O’Dell, Salve, Sunset, Rocker, Tudo, Música Comunicação e Marketing e Loducca $^{103}$.

O idealismo em torno da Criação, que ditou as regras de muitos empreendimentos surgidos nos anos 1970 e 1980, foi ultrapassado pelo peso de importantes instituições globais que passaram a criar redes de dependência no campo da publicidade. O publicitário José Guilherme Vereza destaca, com isso, a necessidade de outras aptidões para o mercado: "Hoje exige-se do profissional, não apenas competência criativa, mas capacidade de pensar a publicidade como um negócio" ${ }^{104}$ Parcerias, concentrações de negócios, sociedades com outros segmentos econômicos, repartições de competências foram o padrão das agências a partir dos anos 2000. Nesses moldes surgiu a África Propaganda, em 2002, com sócios da DDBrasil e do Banco Icatu. A nova agência tinha uma proposta enxuta e dinâmica, como um escritório de atendimento personalizado, dedicado a eventos, marketing direto e publicidade. O nome foi escolhido por ser de fácil entendimento internacional e para homenagear o povo que trouxe muitas influências culturais ao Brasil ${ }^{105}$. No início, a África só podia ter nove clientes e não participava de premiações. Hoje a agência é considerada uma das maiores do Brasil (Abreu; Paula, 2007).

A estratégia de singularizar os clientes adotada pela África apontava para um modelo de agência que nascia com a digitalização das mídias e a passagem para uma comunicação de massa mais direcionada. A publicidade passou a lidar mais incisivamente com a possibilidade de interatividade e intervenção do consumidor, o que provocou transformações no processo de produção de anúncios. Embora sempre tenha sido um polo importante do planejamento publicitário, sobretudo com o advento das pesquisas, o consumo se torna um agente vivo, pulsante, capaz de atuar diretamente na cadeia interna de operações das agências, responder aos apelos de forma imediata. A chamada mídia tradicional baseou-se em um modelo unidirecional, no qual um emissor massivo envia conteúdo para consumidores com poucas possibilidades de intervenção nas narrativas comunicacionais. A mídia digital irá pulverizar esse modelo de

\footnotetext{
103 www.grupoabc.com

${ }^{104}$ Entrevista para a tese.

105 www.africa.com.br
} 
comunicação, proporcionando maior autonomia e poder de interferência por parte dos consumidores. A noção de informação hierárquica, unidirecional, dá lugar a uma versão contemporânea sincrônica e em rede. A relação entre produtores de mídia e consumidores é estreitada, o que provoca uma alteração no fluxo de trânsito da informação. Com a expansão da banda larga e a multiplicação de comunidades virtuais, cresce o número de atores sociais com poder de criação, gerenciamento e distribuição de conteúdos midiáticos. Como argumenta Jenkins (Navarro, 2010), ganha fôlego uma cultura participativa, em que os consumidores são agentes ativos de fiscalização e produção, além de entusiastas criativos que ajudam a definir como o conteúdo midiático deve ser usado e, em alguns casos, dão forma ao próprio conteúdo. Becker (1977) também destaca a participação do público, ou do polo consumidor, como um elo importante da cadeia produtiva necessária à concretização de uma atividade qualquer. Para que um acontecimento seja efetivado, é preciso requisitar plateias capazes de compreender e responder a esse acontecimento social.

A convergência das mídias é antes de tudo um processo cultural, um fenômeno que envolve novas interações sociais entre produtores e usuários de mídia (Jenkins, 2008). Muitas funções da vida cotidiana se deslocaram para o ambiente on-line. O público se conecta às redes sociais para estabelecer novas formas de relacionamento e se engajar de forma colaborativa no ambiente da produção midiática. Neste sentido, o consumidor tem à disposição mecanismos para organizar sua própria grade de consumo midiático e pode optar por suprimir a propaganda. Por outro lado, o consumidor on-line também ganha ferramentas que o aproxima de seus produtos e personagens favoritos, o que aumenta as demandas de engajamento na rede. $\mathrm{O}$ consumo produtivo é uma forma de ação que não permanece passiva, mas que, no ato de consumir um bem cultural, engendra uma interpretação que muda a própria natureza do elemento em questão (Lopes; Gómez, 2010). A papel ativo do consumo pode ser pensado como uma nova peça no conjunto de elementos do mundo publicitário. Como realça Becker (1993), não é possível descartar nenhum tipo de cooperação para a compreensão de um mundo ou uma mudança cultural: 
Cada peça acrescentada num mosaico contribui para nossa compreensão do quadro como um todo. Quando muitas peças foram colocadas, podemos ver, mais ou menos claramente, os objetos e as pessoas que estão no quadro, e sua relação uns com os outros. Diferentes fragmentos contribuem diferentemente para nossa compreensão: alguns são úteis por sua cor, outros porque realçam os contornos de um objeto. (BECKER 1993: 104-5)

Podemos falar, então, da construção de novos consensos, formas inéditas de definir situações e de agir de acordo com elas (Becker 1986). A integração das espacialidades, as novas possibilidades de elaboração do conhecimento interligadas e compartilhadas e o florescimento da noção de rede reforçam a perspectiva sociológica de Becker (1977, 1977a, 1986, 1993). A cultura é vista como uma série de “(...) entendimentos convencionais manifestos em atos e artefatos.” (BECKER, 1986: 12). A dimensão relacional das práticas on-line coloca em diálogo um circuito abrangente de atores sociais e componentes inumanos. Essas reflexões sugerem uma ressignificação de objetos e seres que através da ação conjunta podem originar novas narrativas culturais.

O processo cultural consiste em pessoas fazendo alguma coisa alinhada com seus entendimentos sobre o que é melhor fazer naquelas circunstâncias (...). Se todas têm as mesmas ideias gerais na cabeça e fazem coisas congruentes com esta imagem ou coleção de ideias, o que elas fazem se ajustará. (BECKER 1986: 16)

As articulações que surgem do encontro entre sujeitos e artefatos, e a dependência e coordenação dos elementos entre si para que a materialidade de algo seja concretizada, produzem novas simbologias sociais. As conexões mundiais estabelecidas pela internet modificaram as noções de representação. Reagrupamentos, reelaborações, traçados são propostos para que a representação seja criada (Latour, 2007). A produção do social se dá através dessas alianças entre os atores humanos e não humanos. A oposição entre o que é social, material, factual e o que é subjetivo é desfeita no interior do sujeito, que é resultado dessas junções. Qualquer tipo de conhecimento produzido na internet remete a uma ação colaborativa, a uma vinculação de elementos e a um domínio de materiais que precisa ser apreendido para que um acontecimento exista socialmente. 
O mundo virtual elabora um novo mercado, com complexos processos de compra e infinitas ofertas de produtos e serviços. As práticas de consumo são reconfiguradas culturalmente, uma vez que a velocidade da informação e aproximação com outros espaços e temporalidades transformam os hábitos cotidianos. As agências tiveram que se adaptar para atingir esse consumidor muito mais autônomo, exigente e disperso em múltiplos canais de comunicação.

Com a propagação dos portais de comunicação, como Yahoo e Uol, a publicidade começa a ter mais presença na web, direcionando os usuários para assuntos de seu interesse ou oferecendo possibilidades de segmentação aos anunciantes de acordo com o público-alvo. A capacidade dos mercados eletrônicos aumentou a eficiência do desempenho das empresas, criou vantagens competitivas e disponibilidade das marcas perante o consumidor. Os estudos de marketing destacam a implementação dos conceitos B2B (Business-to-business) e B2C (Business-to-consumer). O primeiro denomina o comércio estabelecido e a troca de informações corporativas entre empresas a partir da adoção de plataformas privadas digitais, como os portais da Intranet restritos aos colaboradores, com o objetivo de substituir as transações físicas, proteger dados e vencer as distâncias. $\mathrm{O}$ segundo se refere ao comércio feito diretamente entre o vendedor ou prestador de serviço e o consumidor final, através das novas possibilidades de interação tecnológicas. Existem três tipos de modelos de $B 2 C$ : leilões eletrônicos, lojas on-line e serviços on-line (Gabriel, 2010).

O panorama digital se tornou tão significativo no mundo da publicidade que o Festival de Cannes passou a premiar trabalhos feitos exclusivamente para o universo on-line. A categoria Cyber Lions foi criada em 1998 e, desde então, já ganhou inúmeras subcategorias para refletir melhor a indústria e as tendências digitais. A AgênciaClick foi a primeira empresa a receber o Cyber Lion Grand Prix com o anúncio "Braille", para o Banco de Olhos de São Paulo. Ao passar o mouse em cima do banner digital, o texto "Doe suas córneas" era revelado ao internauta $^{106}$. Para José Guilherme Vereza, o Festival de Cannes sempre foi um celeiro de tendências do mercado mundial de publicidade.

\footnotetext{
${ }^{106}$ Fonte: www.clubedecriacao.com.br - Disponível em: http://www.clubedecriacao.com.br/ultimas/cannes-lions-48/
} 
O Festival hoje estimula todas as plataformas, todas as mídias, todas as possibilidades de colocar ideias de pé e com a cabeça de negócios. Você tem que transformar ideias criativas em um bom negócio para alguém. O Festival de Cannes trouxe a consciência de que nossa profissão, nossa atividade criativa está a serviço dos negócios. Cannes hoje é uma feira de negócios onde a criatividade é a protagonista ${ }^{107}$.

Com a internet houve uma espécie de transformação na cadeia produtiva de anúncios estruturada nas agências ao longo do século XX. Novos materiais, papéis sociais, linguagens e etapas de realização reorganizaram o sistema de construção de mensagens no campo. O domínio dos processos e empregos de tecnologias ainda está sendo apreendido e adaptado pelos profissionais. A inexistência de uma rotina para a produção publicitária on-line dificulta a eficiência e a rapidez na fabricação de narrativas publicitárias. Os processos ainda não estão completamente regrados por convenções e sucessão de tarefas interpostas. Neste sentido, o investimento em publicidade na internet, apesar de apresentar uma curva ascendente ano após ano, ainda é muito menor do que nos meios tradicionais. De acordo com o Ibope Mídia, a televisão aberta concentrou mais da metade de todo o bolo de investimentos publicitários em 2014. O segundo meio que mais recebeu recursos foi o jornal impresso, logo depois aparece a TV paga, em seguida estão o merchandising em "teleficção" (inserção de anúncios dentro das tramas narrativas) e as revistas. A internet ocupa a sexta posição (Lopes; Gómez, 2015).

O uso de banners eletrônicos foi uma das primeiras formas de publicidade on-line. Os cartazes digitais funcionam como uma espécie de bandeira promocional, uma pequena janela, animada ou não, dentro de um sítio ou portal na internet, contendo uma narrativa publicitária. Alguns banners são interativos ou seguem o padrão pop-up, abas que pulam na tela do computador sem autorização do usuário. Estas peças precisam ser diretas e atrativas para que suas mensagens sejam compreendidas rapidamente.

Com o passar do tempo, a tecnologia permitiu a utilização de recursos mais atraentes para a propaganda digital. Outros modelos e linguagens surgiram para atender novas formas de produzir e distribuir conteúdos. O aparecimento de rádios e televisões on-line alargou o número de anúncios na internet. Para os

${ }^{107}$ Entrevista para a tese. 
produtores de conteúdo, a publicidade novamente foi vista como sustentáculo da estrutura dos meios, mesmo modelo empregado na mídia tradicional (Ferrareto, 2007). Ou seja, desde a consolidação da cultura de massa, a publicidade é o modelo de negócios usado como suporte econômico do mundo da mídia. Desta forma, o campo sempre teve papel privilegiado na construção e organização dos conteúdos editoriais dos meios de comunicação em geral.

O campo da publicidade rapidamente percebeu que precisava posicionar bem suas marcas para ter destaque nesta difusa esfera e captar a atenção do consumidor. A venda de espaços em portais de pesquisa, como Google ou Yahoo, começa a gerar um negócio lucrativo. A facilidade de navegação transformou esses portais em poderosos meios de massa, responsáveis por hierarquizar e controlar a informação consumida em todo o planeta. Os mecanismos de busca on-line modificaram os hábitos e até as cognições humanas (Jenkins, 2008). Consolida-se a percepção de que todo conhecimento disponível no mundo está ao alcance das mãos. Os sujeitos chegam a experimentar uma falta subjetiva quando estão desconectados (Canclini, 2005).

Neste sentido, com o alargamento da internet na vida cotidiana, os anunciantes começaram a perceber que não adiantava mais apenas divulgar produtos e serviços, era preciso fazer com que os consumidores participassem da vida de uma marca, adotassem a marca como elemento identitário. Com base nessa premissa, as agências experimentam métodos para envolver o usuário nos conteúdos, criar histórias interativas, a ponto de incentivá-lo a distribuir aquelas narrativas para os amigos. Estudos foram desenvolvidos com a finalidade de tentar descobrir quem é a audiência, para quem a agência está falando. $O$ intuito é entender o perfil de cada espaço da rede para utilizá-lo da melhor forma, conseguir personalizar as mensagens e interagir com o consumidor (Lapolli, 2008). A troca com o usuário reprogramou as narrativas convencionais da publicidade. Ao endossar o conteúdo de uma marca, ao espalhar de forma viral as narrativas publicitárias, através de canais de circulação on-line ou redes sociais, o consumidor passa a ser o próprio anúncio indireto desta marca. O modelo não é novo, uma vez que a boa e velha atribuição de valor à etiqueta das roupas já fazia do usuário um propagador espontâneo de conteúdos (Rocha, 1995). A internet aumenta o impacto da publicidade, pela sua facilidade de transmissão e recepção. $\mathrm{O}$ grande proveito é que a mensagem se apresenta, assim, de maneira sugestiva. 
Quando recebe uma mensagem de um amigo, o consumidor não considera aquela abordagem uma propaganda, e sim um entretenimento. A conexão é medida pelo seu impacto emocional, ou seja, se o internauta se torna um grande colaborador, ele se sente parte daquela obra e desenvolve uma relação de afeto com aquele produto. Por isso, a experiência não deve ser contida apenas em um único suporte midiático, e sim estender-se ao maior número deles (Jenkins, 2008). Desta forma, a convergência de mídia se torna um modelo de negócios valioso para as grandes empresas de comunicação, ampliando as possibilidades de lucro.

Com a convergência de mídia, estas telas midiáticas se interligam, não são mais estáticas ou ligadas a fios que as alocam em estruturas pesadas e imóveis. As novas telas são caracterizadas pela mobilidade, portabilidade e acompanham o sujeito onde ele estiver. $\mathrm{O}$ celular e os aparelhos móveis remetem à noção de células, partículas que se cruzam e transpõem conteúdos infinitamente, podendo estar em qualquer lugar a cada novo arranjo social. (...) Homens e dispositivos interagem e multiplicam as possibilidades de representação na rede. A convergência alarga as formas de reprodução da experiência humana. (AUCAR; ROCHA, 2012: 119)

Houve uma ampliação na oferta de serviços gráficos, audiovisuais para expandir o alcance das narrativas publicitárias entre as mídias on e off-line. Surgem os widgets, janelas que acompanham os notebooks, tablets e smartphones, a fim de oferecer atalhos para mídias sociais, e-mails ou portais de notícias. A explosão das redes sociais, principalmente o Facebook e o Youtube, abriu espaço para inúmeras possibilidades de anúncios. Algoritmos e programações são capazes de detectar as páginas que o usuário visitou, os itens que clicou, com o objetivo de traçar um caleidoscópio de seus interesses e gostos. Com essas informações, a publicidade passa a oferecer aquele conteúdo individualizado através de redes sociais e e-mails. Além disso, a internet possui um atrativo a mais para os clientes. Agora é possível mensurar, em tempo real, os resultados dos anúncios, otimizando os investimentos. As redes sociais são consideradas veículos extremamente eficientes para a comunicação com o público jovem, urbano, integrante de classes médias que gasta boa parte do seu tempo estabelecendo conexões no mundo on-line (Lapolli, 2008).

Em 2011, a Almap integrou definitivamente suas áreas on-line e off-line. $\mathrm{O}$ Departamento de Criação se tornou responsável por dirigir todos os trabalhos 
desenvolvidos, independente da mídia. Antes deste projeto entrar em prática, a ideia primeiro era desenvolvida para a mídia off-line e posteriormente realinhada para a mídia on-line. A partir da integração, as "duplas de criação" do on-line passaram a se envolver no processo desde o início do planejamento ${ }^{108}$.

Na DM9, a Criação também agregou novos profissionais. As duplas passaram a trabalhar em trios, com mais um diretor para a área de internet. Grandes clientes solicitam campanhas completas, com inserções em diferentes espaços de comunicação. Já outros, preferiram apostar somente na inovação e no imediatismo da internet. No entanto, dada a diversidade da mídia digital, as ações on-line são tão complexas e segmentadas que geraram uma pluralidade de diferentes estratégias. A nova dinâmica das agências comprova que a ação coletiva e a colaboração entre as partes são efetivas para o aparecimento de um produto social em qualquer área do conhecimento (Becker, 1977). Na margem social entre os diferentes setores das empresas e na interação entre os profissionais, conflitos são frequentes, uma vez que “(...) cada grupo encontra o outro trazendo um conjunto estabelecido de ideias sobre como as coisas devem ser feitas, quem dá as ordens, como o dinheiro é divido e distribuído e assim por diante." (BECKER 2003: 02).

A estrutura espacial das agências também sofreu algumas alterações, com a crescente demanda de anúncios para o universo da internet. $\mathrm{O}$ dinamismo do mundo on-line acoplou a ideia de modernidade e fluidez à arquitetura das empresas. Ambientes integrados, sem paredes, com grandes salas abertas, onde os diferentes departamentos estão instalados sem nenhuma divisória ou parede. Esta foi a decoração adotada por agências contemporâneas, como: $D M 9 D D B$, Loducca22, Ogilvy e África. As "duplas de criação" são acomodadas uma ao lado da outra em amplas mesas integradas. Sofás e puffs coloridos também fazem parte dos espaços comuns. Paredes e objetos privilegiam cores marcantes, como o amarelo usado nas paredes da DM9 ou o vermelho da Ogilvy. A África é ornamentada com quadros e esculturas que remetem à cultura africana. As agências se diferenciam do ambiente convencional dos escritórios comerciais pela adoção de peças com design original e arrojado, grafismos ou obras de arte nas

\footnotetext{
${ }^{108}$ Fonte: Propmak. "AlmapBBDO integra áreas on e off-line." Reportagem publicada em 20 de maio de 2011. Disponível em: http://propmark.com.br/agencias/almapbbdo-integra-areas-on-eofflineD
} 
paredes, mesas de pebolim, estantes de livros, lustres e luminárias elegantes, jardins de inverno, que ressaltam a criatividade no alinhamento dos elementos. A maioria das salas de reunião são separadas dos recintos coletivos com paredes de vidro. A entrada da DM9 paulista possui uma gigantesca escultura de corda iluminada que atravessa todos os andares da empresa. O enorme prédio da agência situado na Avenida Brigadeiro Luís Antônio, em São Paulo, chama a atenção de quem passa pelo letreiro com cores fortes na fachada. Um grande destaque é o sistema digital, com várias telas de computadores instaladas nas paredes de todos os andares. Os funcionários podem visualizar um banco de dados, atualizado em tempo real, com informações do mundo dos negócios, dos clientes da agência e das tendências em circulação nas principais redes sociais. O prédio da Loducca, em São Paulo, vizinho da $D M 9$, também foi projetado para impactar a paisagem urbana. O edifício possui a lateral toda vazada com uma estrutura de vidro recortada por réguas de madeira. A arquitetura foi pensada privilegiando materiais que protegessem a agência dos ruídos externos. De forma geral, nas visitas às agências, pude observar que as mudanças estruturais reproduzem os modelos espaciais. A organização do trabalho também corresponde a uma organização arquitetônica da agência. Os portais on-line também apresentam visual moderno, design dinâmico, recursos interativos, fotos das equipes profissionais com valorização de suas aptidões, imagens e vídeos de seus clientes mais renomados. Os sítios das empresas DM9DDB, JWT, África, AlmapBBDO, Loducca, Lew'Lara, W/McCann, Young \& Rubicam, Ogilvy, Publicis, Leo Burnett, F/Nazca, NeogamaBBH, DPZ possuem as seguintes subcategorias: história, pessoas, clientes, valores, prêmios, notícias, campanhas, acionistas, atalhos para redes sociais, contatos. A maioria deles traz fotos de suas instalações físicas com fotografias em alta qualidade. As configurações atraentes buscam reforçar a aparência de empresas inovadoras, preparadas para lidar com os rápidos e constantes desafios impostos por um mundo global.

Paradoxalmente, a imaterialidade do ambiente on-line põe em xeque a necessidade de escritórios físicos, muitas vezes dispendiosos. As novas apreensões do tempo e espaço e o acesso a tecnologias de ponta permitem também a organização de microagências, com uma ou duas pessoas trabalhando em suas próprias casas. Com isso, o aparecimento das startups movimentou o mercado da publicidade. Essas empresas iniciantes de tecnologia desenvolvem 
produtos e serviços e têm a internet como canal de distribuição. O propósito é buscar um modelo de negócios inovador a baixos custos. No mundo contemporâneo é mais barato criar uma empresa de software do que uma indústria, por isso as startups são mais frequentes na internet. Muitas agências atuais estão investindo em startups para desenvolver novas plataformas e cavar oportunidades $^{109}$. A JWT criou um núcleo focado em desenvolvimento de produtos digitais para seus diversos clientes, através da instalação de uma startup dentro da matriz.

Acredita-se que as startups podem ajudar com estratégias diferenciadas para as agências, relações com profissionais empreendedores e parcerias para aquisições. Em um cenário onde o consumidor possui recursos para se tornar um desenvolvedor de conteúdo e também um vendedor para milhares de pessoas ao redor do mundo, o setor da publicidade busca caminhos para não perder a posição de um campo de conhecimento sólido e significativo para a sustentação da economia planetária.

A proximidade histórica do fenômeno não nos dá o distanciamento necessário para a elaboração de uma perspectiva crítica melhor definida. Trata-se de algo "em construção" e, portanto, de difícil apreensão de um perfil mais acabado. A dinâmica do processo interacional entre produtores e consumidores sempre esteve em andamento e, nesse momento, parece que novos movimentos nesse jogo se atualizam constantemente. O diálogo entre sujeitos, objetos e narrativas se intensifica, aproxima elementos, complexifica temas, reposiciona práticas, tanto inova, quanto repete - enfim, como todo processo em gestação, será o distanciamento que irá permitir as melhores interpretações.

\footnotetext{
${ }^{109}$ Fonte: Revista Exame. Disponível em: http://exame.abril.com.br/pme/noticias/o-que-e-umastartup
} 


\section{7 - Considerações finais e perspectivas de pesquisas futuras}

Este trabalho se propôs a analisar um século de publicidade no Brasil, com ênfase na organização do trabalho a partir das agências, instituições que funcionaram como força centrípeta do espaço simbólico, no qual os agentes sociais legitimaram as representações e estratégias de poder do campo. As classificações dos signos, os rituais, os valores, os códigos de conduta, os elementos pertencentes ou não ao mundo da publicidade foram delineados dentro das estruturas erguidas por essas empresas de comunicação. Assim, a agência se firmou como instituição de integração social, que viabilizou, tanto a socialização da profissão, quanto a reprodução dos significados estabelecidos no setor.

Portanto, a inauguração da primeira agência no país, há cerca de cem anos, foi o marco que localizou o início dessa investigação. Os primeiros movimentos organizacionais permitiram a imersão em um processo construído historicamente, a fim de validar um campo do conhecimento, com o reconhecimento público da profissão de publicitário, tecnologias próprias, disputas, rotinas e estratégias produtivas. A formação e a autoridade social e jurídica do campo dotaram a publicidade de um papel central no desenvolvimento da área da comunicação como um todo, além de validar sua posição privilegiada nas redes de comando e na afirmação de códigos culturais ao longo do tempo.

Nesse sentido, a análise dos movimentos das principais agências demonstrou a importância do encadeamento dos códigos internos do segmento para a compreensão social dos efeitos manifestos da produção publicitária, bem como confirmou a presença fundamental da estrutura midiática na formação da cultura nacional. Quando se fala em história da publicidade, é preciso realçar quem é o produtor destas mensagens, como funcionam essas empresas, como cada convenção foi demarcada, como se deu a certificação pública e a circulação de conteúdos. Ou seja, conhecer as estratégias, pactos, ajustes, valores, categorias, poderes que as agências invocam em seu discurso e as implicações sociais decorrentes dessa experiência. 
A pesquisa buscou mostrar como o setor da publicidade, sustentado por agências, é parte preponderante do cotidiano brasileiro, ao menos economicamente, de um processo de comunicação que determinará escolhas e estilos de vida. A representação publicitária, formada a partir de narrativas ficcionais, se tornou uma arena construtora de sentidos e significados incorporados pelos atores sociais para transitar no complexo mapa da identidade cultural. Tais representações estiveram encadeadas com os movimentos da nossa história e com as práticas de consumo que traduziram a experiência brasileira nestes últimos cem anos.

Rocha $(1985,1995,2007)$ tem demonstrado, a partir de sua discussão original da publicidade, como o consumo pode ser considerado um fenômeno organizador das escolhas, divisões, diferenciações e hierarquias do espaço coletivo, oferecendo códigos de circulação na cultura. O consumo, como elemento classificador, categoriza os grupos sociais e cria regiões simbólicas que elaboram nossas histórias de vida. Em diálogo com esta perspectiva teórica, este estudo foi motivado pela necessidade de pensar a publicidade como narrativa do consumo, através de seu desenvolvimento empresarial e solidificação do campo no país. As definições para a existência do produto social do anúncio e para a interpretação cultural desse dispositivo foram resultado e manifestação das engrenagens internas das agências, suas rotinas produtivas e identidades em constante processo de negociação.

Inúmeros trabalhos refletiram as ligações entre publicidade e construção do imaginário coletivo. No entanto, a maioria das abordagens colocou foco sobre alguns produtos específicos ou apreciação de décadas particulares (Carrascoza; Hoff, 2009, 2011a; Fico, 1997; Figueiredo, 1998; Rabelo, 1956). Surgiu, então, a oportunidade de contribuir para as discussões sobre a dimensão cultural da publicidade através do olhar que privilegia a agência de propaganda como uma grande organizadora e produtora das demarcações do setor.

Para enunciar a autonomia das agências e a construção de uma imagem pública favorável para a profissão, algumas premissas metodológicas foram estabelecidas desde o início da pesquisa. A primeira compreende o extenso corte temporal adotado. Apesar do largo espaço de tempo, o enfoque não se ateve apenas à cronologia sequencial dos fatos, e sim aos grandes movimentos que transformaram o campo. O percurso histórico não foi dirigido pela sucessão 
linear, mas pelas principais mudanças discursivas que ajudaram a consolidar o setor ao longo de um século. O incremento tecnológico, as influências estrangeiras, o aparecimento de novos meios de comunicação foram fatores que vincularam o desenvolvimento da publicidade ao nascimento de uma cultura massificada, midiatizada e apoiada em conjunturas econômicas que aportaram no consumo o destino de boa parte de suas interações materiais e subjetivas. A tradição interacionista de Howard Becker (1977, 1977a, 1986, 2008 [1963]) aplicada, tanto em trabalhos que avaliam o desvio social, quanto em estudos sobre o universo da arte, aportou a reflexão sobre as identidades culturais dos sujeitos envolvidos na cadeia produtiva dos anúncios e suas práticas coletivas ordenadas historicamente. O aparecimento social da narrativa publicitária e suas interpretações no mundo moderno-contemporâneo foram pensados a partir das redes de atividades cooperativas e de troca dos participantes organizados nesta espécie particular de espaço simbólico: o campo da publicidade. Nesse setor, relativamente novo na dinâmica social, as ações necessárias à produção, distribuição e recepção de anúncios tomaram forma e tradução. Para Becker (1977), a ação grupal designa as condições de possibilidade para a viabilidade de um produto em si, devendo ser parte essencial do repertório de entendimentos que norteia as percepções e os exercícios dos agentes desses mundos. Para entender como os atores sociais conseguiram abranger em um espaço social uma multiplicidade de relações complexas e representações, o estudo recorreu ao pensamento de Pierre Bourdieu (1983 [1976], 2009 [1980]). O conceito de campo, central na obra do autor, enuncia um ambiente de disputas e convergências entre grupos. Choques, desentendimentos, lutas simbólicas são derivados das relações de poder para traçar as definições do campo. Um campo se configura a partir das instituições, relativamente independentes, com uma lógica intrínseca, posições de comando, tecnologias, habitus determinados pelos grupos dominantes, a partir de uma situação histórica. A formação desse senso comum é construída gradativamente, em ações pouco percebidas pelos atores sociais, pois o campo tem caráter imperativo, é uma construção social estabelecida e respeitada.

A pesquisa também foi sustentada por estudos que destacam os sentidos sociais elaborados pelas mensagens publicitárias como narrativa central do fenômeno do consumo. Reflexões importantes para relacionar aspectos históricos ao papel da publicidade como um discurso de poder na cultura moderno- 
contemporânea. Essa perspectiva teórica foi estimulada por autores como Mary Douglas e Baron Isherwood (2004 [1979]), Marshall Sahlins (1979), Jean Baudrillard (2010 [1970]), Collin Campbell (1987), Daniel Miller (2002), Everardo Rocha (1985) e Pierre Bourdieu (2007 [1979]). É na crescente estrutura midiática que o consumo se transformará em mensagem persuasiva através da narrativa publicitária e o desenvolvimento de linguagens cada vez mais atraentes e instigantes pelas agências. Assim, o consumo influenciará práticas cotidianas e subjetividades, conduzindo valores e crenças no imaginário coletivo. Como reforça Jean Baudrillard (2010 [1970]), o consumo desponta como um grande sistema de compartilhamento de significados e determinará parte das definições de felicidade de nosso tempo.

O desvelamento da lógica do campo ofereceu indícios de um processo comunicacional amplo e difuso. O relacionamento entre profissionais, meios de comunicação, marcas, empresários e consumidores abriu lacunas para novos significados e projeções culturais. As entrevistas com publicitários que fizeram parte desta dinâmica profissional em diferentes momentos dessa história também foram importantes métodos para colher vestígios do passado ressignificados pela memória. Profissionais que participaram do cotidiano dessa indústria e ajudaram a construir diretrizes do setor no país lembraram de suas trajetórias profissionais, representações da profissão, fluxos de trabalho nas agências e momentos históricos do segmento. Depoimentos de alunos e professores de publicidade também contribuíram para ampliar o debate e ajudar na apreensão do pensamento de atores que circulam em diversas facetas do campo. Não podemos deixar de considerar que o passado, novamente reinterpretado pelo escritor, ganha uma vivência que apenas pode se acomodar nos contornos da aparência, do indício, do disfarce.

Outra premissa metodológica, que buscou preservar o espírito etnográfico, também foi acentuada com visitas a agências de publicidade do Rio de Janeiro e de São Paulo, o que permitiu uma aproximação do cotidiano produtivo, das divisões espaciais e da imagem cultivada pelos publicitários. As visitas realizadas nas agências DM9DDB, Loducca, Ogilvy \& Mather e África Rio permitiram uma observação participante acerca da disposição dos atores sociais, suas redes de colaboração, rituais de produção, indumentárias e estilos profissionais, assim como foi possível verificar a disposição dos elementos arquitetônicos que traçam 
limites espaciais entre as diferentes funções e posições. A relação entre os espaços físicos e os movimentos de transferência de poder no campo ficaram evidentes ao longo de toda a pesquisa. Espaços nobres ou grandiosos dentro dos ambientes profissionais são sempre ocupados pelos agentes dominantes. É possível conhecer a relação hierárquica de uma empresa observando suas demarcações espaciais. Os sítios de comunicação digital das principais agências do país também foram visitados para entender a composição das representações publicitárias e ações produtivas a partir do advento tecnológico da internet.

Como nos ensinou Geertz (1989 [1973]), o trabalho de campo deve ser valorizado como uma eficiente forma de se promover a imersão na cultura do outro. O mergulho no ponto de vista nativo, sob o cuidado da relativização e da contextualização de dados, suscita a produção do conhecimento científico. Estabelecer relações, selecionar informantes, decodificar textos, encontrar procedências, mapear campos foram os principais procedimentos adotados para retratar o mundo da publicidade.

Procuramos percorrer cem anos desta história singular a partir de resíduos que retornam ao presente através da pesquisa e se materializam com a interpretação crítica do pesquisador. Evidentemente, não tivemos a pretensão de promover um inventário sobre a trajetória de todas as agências que circularam no Brasil, mas radiografar os movimentos que impactaram a construção e desenvolvimento do campo através das principais empresas que se destacaram pelo reconhecimento do mercado.

A revisão das pesquisas acadêmicas sobre a publicidade brasileira foram de fundamental importância para a formulação de uma problemática que girou em torno dos atores sociais e suas práticas coletivas. O primeiro capítulo foi dedicado à sistematização de algumas das muitas interpretações disponíveis sobre a publicidade, que ajudaram a sintetizar as principais teses que permeiam esta área da comunicação. Caracteristicamente vista como instrumento econômico, a publicidade é examinada em seu aspecto prático e funcional no interior das engrenagens capitalistas, assim como é criticada por legitimar essa mesma ordem. O quadro teórico, desenvolvido principalmente por antropólogos e historiadores, foi o que mais influenciou esta reflexão. Estudos que ultrapassaram o viés produtivista e deram atenção ao plano dos significados culturais que a publicidade desenvolve através de relatos e práticas de consumo. A publicidade é 
compreendida, não apenas por sua finalidade comercial, mas especialmente por sua função comunicativa, de troca de sociabilidades, de intercâmbio de códigos e posições sociais. Portanto, a sedução das linguagens, a magia das imagens, a propagação de uma irrealidade e a representação do ideal de felicidade contemporânea são artifícios empregados na construção de discursos que impactam os desejos íntimos do sujeito e corroboram para a valorização do consumo como fonte de realização subjetiva.

Frente a tantas possibilidades de leituras, o estudo procurou demarcar conceitualmente a publicidade. No capítulo dois, o trabalho no campo e a construção das narrativas publicitárias propagadas na cultura foram pensados como questões inscritas na atualidade, erguidas a partir de um conjunto de condições organizadas no tempo presente. O relevo dado ao pensamento racional e tecnológico, a composição dos sistemas industriais, as concentrações urbanas, o aumento das distâncias geográficas e o aparecimento de meios de comunicação que se puseram como mediadores da experiência social foram fatores que esboçaram esse novo momento histórico, que chamamos de modernidade. Assim, a construção e o entendimento coletivo da narrativa publicitária aparecem como resultado de ações coletivas coordenadas em estruturas conformadas por símbolos, processos, materiais, identidades forjadas em determinado período.

A questão principal que dirigiu a pesquisa circulou em torno do papel imperativo que os atores sociais e suas ações exercem na produção do conhecimento e das identidades culturais de determinado sistema. Os produtos sociais e suas estruturas de sustentação resultam de atividades conjuntas e integradas, que negociam constantemente os significados em trânsito num determinado meio. Procurou-se valorizar a mobilidade dos atores, o dinamismo de suas práticas e capacidades de ressignificarem seus papéis culturais. Logo, há de se considerar o caráter movediço da história, que é feita de pequenas permanências, mutações a cada fluxo de acontecimentos. Inconstâncias, irregularidades e contradições fazem parte do movimento da história. De acordo com as premissas de Chartier (1990), a cultura deve ser percebida por suas diversidades internas, com atores sociais capazes de circular entre diversas alternativas ou capazes de se apropriar criativamente das alternativas culturais.

No capítulo três, os rituais e estratégias de interação foram vistos como elementos categóricos para a compreensão dos processos de construção social da 
realidade com a base conceitual de Howard Becker (1977). A teoria da ação coletiva ganha força no fim dos anos 1970 como uma proposição que distinguirá os comportamentos sociais a partir de trocas entre os sujeitos, de projetos desenvolvidos por grupos, de arquétipos criados para denotar comportamentos considerados corretos e aceitos socialmente. A partir da alteridade, o desvio se estrutura como uma vertente social e não como uma disfunção orgânica ou consequência biológica já prescrita no indivíduo desviante. As convenções e modos de organização são resultado de acordos coletivos instituídos em condições históricas que se alteram no tempo e no espaço. Logo, as valorações de cada campo do conhecimento são construídas socialmente, através de regras e normas que expressam circuitos de dependência entre seus integrantes. As identidades culturais são arquitetadas com base nestas balizas de orientação social, e o comportamento individual é planejado através do entendimento dos códigos em curso e adaptabilidade às convenções.

As agências de publicidade instituíram as condições de existência da narrativa publicitária, tal como a entendemos no mundo moderno-contemporâneo. A materialização e o entendimento do anúncio, como um acontecimento social, foram ponderados em decorrência de uma ação coletiva engendrada no interior das empresas de comunicação. Assim como um concerto musical, o discurso publicitário teria nascido do intercâmbio de identidades, cuja colaboração é necessária para a organização de uma cadeia produtiva. Para Becker $(1977,1977$ a, 1986), qualquer trabalho é resultado de uma atividade conjugada, um entrelaçamento de fatores que permite que um produto apareça e seja compreendido. Tanto os sistemas, quanto as identidades culturais são formados por atores e suas competências combinadas. Desta forma, seja qual for o objeto em curso, qualquer universo pode ser entendido como o resultado de tramas grupais correlacionadas. Os atores sociais em conjunto elaboram a produção do conhecimento, bem como as estruturas que adequam seus sistemas de criação.

As disposições da agência de propaganda foram constituídas como arenas de disputa e ordenação das identidades do campo publicitário. Essas empresas, que começam a despontar no Brasil ainda na primeira década do século $\mathrm{XX}$, se tornaram polos substanciais para o nascimento da propaganda moderna e para a difusão de conteúdos culturais, como vimos no capítulo quatro. A articulação das identidades projetadas pelo universo midiático, as redes solidárias e tratados 
fixados internamente foram determinantes para a materialização de mensagens sobre produtos e serviços em meios de comunicação. A agência ofereceu uma organização necessária e eficiente para que o mercado de mídia pudesse depender de anúncios como base de sustentação financeira. Assim, as agências projetaram e fortaleceram um campo que passou a ter papel de liderança no aparelhamento da indústria da comunicação e na economia brasileira como um todo.

Nesse sentido, as considerações de Bourdieu (1983 [1976]) sobre o espaço social foram apropriadas para o entendimento das demarcações de um campo. Cada divisão organizada culturalmente obedece a leis, hierarquias, disputas, interesses, acordos, jogos, capitais simbólicos particulares desenvolvidos em torno de cargos ou ocupações específicas que assumem características identitárias e estabelecem relações de poder. As diretrizes do campo são oriundas de batalhas travadas pelos atores sociais. Tais disputas são atualizadas com regularidade, indicando a dinâmica ativa do jogo existente em cada campo. O conjunto de forças objetivas é infligida a todos os agentes produtivos. Na ordenação capitalista um campo ganha maior ou menor importância a partir de sua correlação com os agentes econômicos e capacidade de influência cultural. Ao longo do tempo, a publicidade foi conquistando autoridade e reconhecimento como um setor necessário à vida coletiva em sociedades que se fundamentam na produção indiscriminada do simbólico.

Desde o surgimento da Eclética, nossa primeira organização empresarial publicitária, que um sistema próprio foi montado na direção de um desenvolvimento profissional e consolidação de um setor. A agência instala uma rotina particular de produção de mensagens publicitárias, apresentação de ideias criativas, aproximação de veículos, moldes de investimentos e formas de remuneração. São regulações construídas em confluência com os sujeitos do campo e que estabelecem funções de competência e sequências de afazeres concatenados (Becker, 1977, 1986).

O modelo brasileiro foi inspirado em companhias norte-americanas e europeias que, desde meados do século XIX, se dedicavam à compra e venda de espaços em meios de comunicação. Instalada na capital paulista, em 1914, a Eclética, estabelece uma modalidade de negócios que até então era praticada de forma amadora, como uma "ação entre amigos", quando os donos de pequenos empreendimentos concordavam em comprar espaços em jornais para promover as 
vendas. A corretagem de anúncios pelas agências marca o princípio da atuação comercial e do aparelhamento administrativo da publicidade. Com o fortalecimento do mercado a partir da década de 1930 e a chegada das companhias internacionais, o segmento assume perfil próprio, com estruturas mais robustas e complexas. A agência especializou-se em encontrar negócios e mercados, examinar o poder financeiro de seus clientes e dos consumidores em geral, estudar e distinguir o perfil psicológico dos compradores, calcular e planejar vendas, canais de distribuição, cogitar táticas para valorizar os espaços nos meios, incorporar capacidades artísticas de seus funcionários para a produção de anúncios e uma infinidade de outras ações para a fundamentação dos domínios da propaganda (Sant'Anna et al, 2009).

A prosperidade do meio foi alcançada aos poucos, com a consolidação gradativa de papéis e pactos profissionais. No capítulo cinco, vimos que importantes modelos produtivos foram experimentados a partir dos anos 1960, conferindo uma atmosfera de modernização ao mercado. O Departamento de Criação ganhou autonomia na cadeia operacional das agências e assumiu posição de liderança. A ênfase na criatividade conduziu os principais embates e disposições arquitetônicas das empresas nesse período. $\mathrm{O}$ aprimoramento técnico e o investimento em pesquisas mais sofisticadas também agregaram valor e confiança comercial ao segmento. Com os festivais internacionais, o campo acionou novos mecanismos de legitimação, disputa e reconhecimento. Para aliar respeito e status ao papel de assessorar as empresas capitalistas em suas necessidades de comunicação, o segmento também projetou uma imagem adequada para seus profissionais. Bourdieu (1983 [1976]) enfatiza que a quantidade de capital social de cada agente, ou seja, a acumulação da cultura própria de uma classe herdada ou adquirida mediante socialização, determinará as diferentes posições em um campo. Estipulado em oposição às funções vizinhas, um cargo colocar-se-á como um instrumento de poder. Assim, a construção de uma identidade cultural renomada para a profissão de publicitário ajudou a mudar a percepção sobre o meio. A atividade marginalizada nas primeiras décadas do século XX ganhou, pouco a pouco, uma posição social sólida, com uma aparência de sofisticação e lucratividade (Rocha, 1985).

A rede de relações interpessoais necessária ao aparecimento social do anúncio foi sofrendo reordenamentos a cada emprego de materiais e 
transformações históricas. Conforme assegura Becker (2003), as regras dos sistemas não são estáveis e sofrem uma série de interferências e apropriações de outros grupos de pessoas e redes de comunicação. Um fenômeno está tangenciado por uma cadeia de dependências externas, e é considerado, neste sentido, um sistema aberto com grande liberdade de entrada e saída, novos domínios e imprevistos. O capítulo seis traz apontamentos sobre a necessidade de adaptação das agências, tanto conceitual, quanto estruturalmente, frente aos processos de globalização e informatização de mercados. Concessões e compromissos comerciais foram travados como resultado de lutas sobre as convenções a respeito das formas e representações publicitárias do novo milênio. A fragmentação dos meios, o apreço tecnológico e as novas conexões entre produção e consumo deflagraram necessidades inéditas para o setor. Como sugere a própria dinâmica da internet, o interacionismo simbólico é ainda mais acentuado nos processos virtuais. A proximidade das transformações e o ritmo acelerado dessas mudanças oriundas do universo digital não nos permite uma análise acabada dos conflitos, das definições teóricas e práticas do campo.

Acompanhamos esses movimentos históricos de organização do campo publicitário com relevo em suas categorias institucionais de conservação. A agência foi a instância que incorporou tecnologias e as transformou em dispositivos de comunicação, criou papéis e definiu identidades profissionais que se tornaram publicamente reconhecidas, assistiu alternâncias de poder entre essas identidades, assumiu métodos que construíram um saber específico que legitimou, debateu, articulou e viabilizou leis que soldaram a sustentação da publicidade no mundo social.

Com o imenso espaço ocupado pelo consumo nas vivências cotidianas, a narrativa publicitária se consolidou como um grande dispositivo que, através de suas mensagens persuasivas, oferece componentes para a tradução da cultura e construção de subjetividades. A comunicação midiática mudou a disposição de representações em nosso tempo, logo de realidades. A interação local foi substituída por interações à distância, por novos modos de relacionamento entre os sujeitos. Outras formas de produção do conhecimento se estabeleceram e transformaram as identidades culturais. Nossas interpretações, capacidades de estabelecer critérios de diferenciação, de catalogar, nomear, dar significados às práticas culturais foram motivadas pela vinculação com a mídia (Kellner, 2001). 
A publicidade participou diretamente da vida pública brasileira, acompanhando as transformações econômicas, as mudanças políticas, os processos de industrialização e o estreitamento subjetivo travado entre sujeitos e artefatos materiais. O mundo dos objetos constituirá um apoio, uma base para as relações sociais, amplamente mediadas pelo aparato técnico (Latour, 2007).

Nesse sentido, a história assume um caráter interpretativo de construção de fatos e identidades culturais, e não somente participa do texto como paisagem de acontecimentos. Diante da dificuldade em encontrar definições para a história cultural, dado seu caráter multidisciplinar, este trabalho leva em conta as conclusões de Peter Burke (2005). Em sua impressionante pesquisa sobre as transformações no conceito de história cultural, o autor observa a preocupação com o simbólico e suas representações culturais como um ponto comum entre todos os historiadores culturais. Certeau (1982) defende a história como constituição cultural e admite seu caráter inventivo, de construção de enredo. Desta forma, esta escrita não procurou remontar o passado tal como ele se deu, mas oferecer uma apreciação, que ganhará nova vida com as múltiplas possibilidades de exame dos leitores.

Por isso, a publicidade não pode ser apenas ponderada como o simples retrato do pensamento de um tempo; a utilidade de seu discurso está, sobretudo, na capacidade de associar comportamentos e promover modos de autoconhecimento, sejam eles aceitos ou não. A produção e organização das agências ofereceram, em muitos momentos, narrativas que espelharam a vida cotidiana, mas também serviram à construção de um mundo imaginário, esperançoso de realização, ou promoveram a nostalgia de um passado simulado. Nesta irrealidade simbólica, a publicidade diz quem somos, o que fomos e o que poderemos ser (Mazetti, 2014). Portanto, a vinculação com os projetos nacionais não foi o único canal de expressão deste campo, que se interpôs pelas individualidades, chegando ao plano do devaneio, da fantasia. A publicidade moderna confirma então sua dimensão construtora de subjetividades.

A partir da adesão dos sujeitos ao discurso publicitário, produzido por agências, uma ordem intelectual é operacionalizada e instaurada no corpo social, construindo signos perpetuados através do tempo. Entender os movimentos do campo profissional é também descortinar os mecanismos de fabricação desta poderosa narrativa. Ademais, a própria pesquisa histórica da disciplina já 
denuncia a maturidade que o campo assume culturalmente, e abre possibilidades para outros estudos de fenômenos e atividades da comunicação, com foco nos pilares organizacionais construídos ao longo do tempo em cada espaço simbólico e na ideia de colaboração entre os participantes de um mundo social.

Por fim, resta dizer que, mesmo aberta à densa cadeia das interpretações, a análise histórica é uma forma de atingir o sonho da imortalidade, como argumenta Certeau (1982):

Nomear os ausentes da casa e introduzi-los na linguagem escriturária é liberar o apartamento para os vivos, através de um ato de comunicação, que combina a ausência dos vivos na linguagem com a ausência dos mortos na casa. Desta maneira, uma sociedade se dá um presente graças a uma escrita histórica. A instauração literária deste espaço reúne, então, o trabalho que a prática histórica efetuou. (CERTEAU, 1982: 107)

A escrita histórica tem, portanto, a capacidade de exorcizar a morte (Barbosa, 2007), trazendo o passado ao presente, sempre contínuo, mesmo que imutável, e cumpre a função simbólica de abrir espaço para o ininteligível, o desconhecido, em algum outro momento do percurso social. 


\section{8 - Referências bibliográficas}

ABAP, Associação Brasileira de Agências de Propaganda. História da Propaganda Brasileira. São Paulo: Editora Talento, 2005.

ABRANCHES, Maria Aparecida da Silva \& HOFF, Tania. Peças publicitárias: a busca pela distinção criativa no contexto de Premiações e Portfólios. XVIII Congresso de Ciências da Comunicação na Região Sudeste. Bauru, São Paulo, julho de 2013.

ABREU, Alzira Alves de \& LATTMAN-WELTMAN, Fernando. Fechando o cerco: a imprensa e a crise de agosto de 1954 In: GOMES, Ângela Maria de Castro (org.). Vargas e a crise dos anos 50. Rio de Janeiro: RelumeDumará, 1994.

ABREU, Alzira Alves de \& PAULA, Christiane Jalles de (coords.). Dicionário histórico-biográfico da propaganda no Brasil. Rio de Janeiro: Editora FGV, 2007.

ABRIL CULTURAL. 100 Anos de Propaganda. Anúncios publicitários de 1875 a 1980. São Paulo: Abril Cultural, 1980.

ADORNO, Theodor W. \& HORKHEIMER, Max. A Dialética do Esclarecimento. Rio de Janeiro: Jorge Zahar Editor, 1991 [1947].

AGUIAR, Leonel. Entretenimento: valor-notícia fundamental no jornalismo. Estudos em Jornalismo e Mídia, UFSC, v. 5, n.1, p. 13-23, jan./jun. 2008. Disponível

em:

$<$ http://www.periodicos.ufsc.br/index.php/jornalismo/article/viewFile/10674/ 10217>.

ALBUQUERQUE, Francisco. A fotografia publicitária. IN: CASTELO BRANCO, R.; MARTENSEN, R. L. \& REIS, F. (eds.). História da propaganda no Brasil. São Paulo: T.A. Queiroz, 1990.

ALMEIDA, Gelsom Rozentino de. História de uma década quase perdida - PT, CUT, crise e democracia no Brasil: 1979-1989. Rio de Janeiro: Garamond Universitária, 2002.

ALMEIDA, Luiz Pedro Moutinho de. Algumas notas biográficas sobre Fernando Pessoa. Setubal: Tip. Sado, 1954.

AMORIM, Carlos. Travessias e travessuras de uma indústria caótica. IN: RODRIGUES, Ernesto. No próximo bloco, o jornalismo brasileiro na TV e na internet. Rio de Janeiro: Ed. PUC-Rio/Ed. Loyola, 2005.

AMORIM, Edgar Ribeiro. História da TV Brasileira [recurso eletrônico]. Coleção Cadernos de Pesquisa. Volume 11. São Paulo: Centro Cultural São Paulo, 2007. 
ASSIS, Machado. O Espelho. IN: COUTINHO, Afrânio (org.). Obra Completa. Volume III. Rio de Janeiro: Nova Aguilar, V.III, 1959 [1859].

AUCAR, Bruna \& ROCHA, Everardo. Isto é...Fantástico: televisão, revista eletrônica e consumo no Brasil. Dissertação de mestrado. Pontifícia Universidade Católica do Rio de Janeiro, Departamento de Comunicação Social, 2012. Disponível em: <http://www2.dbd.pucrio.br/pergamum/biblioteca/php/mostrateses.php?open=1\&arqtese $=10119$ 30_2012_Indice.html>.

AUGUSTO, Regina. No centro do poder: a trajetória de Petrônio Corrêa, fundador da MPM e o maior articulador da publicidade brasileira. São Paulo: Virgiliae, 2013.

BAHIA, Juarez. Jornal, história e técnica. São Paulo: Ática, 1990.

BAKHTIN, Mikhail. A cultura popular na Idade Média e no Renascimento. São Paulo: Hucitec, 1999.

BARBOSA, Marialva. O Cruzeiro: uma revista síntese de uma época da história da imprensa brasileira. Revista Ciberlegenda. n 7, 2002. Rio de Janeiro: PPGCOM, UFF.

História cultural da imprensa: Brasil 1900-2000.

Rio de Janeiro: Mauad X, 2007.

História cultural da imprensa: Brasil 1800-1900.

Rio de Janeiro: Mauad X, 2010.

O passado e o presente como processo comunicacional. USP- Revista Matrizes. Ano 5 - no 2 jan./jun. 2012. p. 145-155. São Paulo.

BARRETO, Roberto Menna. Agência de propaganda e as engrenagens da história. São Paulo: Summus Editorial, 2006.

BARTHES, Roland. Mitologias. São Paulo: Diefel, 1989 [1957].

BASTOS, Fernando \& DAYRELL PORTO, Sérgio. Análise hermenêutica. IN: DUARTE, Jorge; BARROS, Antonio \& NOVELLI, Ana Lucia Romero. Métodos e técnicas de pesquisa em comunicação. São Paulo: Atlas, 2006.

BASTOS, Pedro Paulo Z. \& FONSECA, Pedro Cezar Dutra. (Orgs.). Era Vargas: Desenvolvimentismo, Economia e Sociedade. São Paulo: Unesp, 2012.

BAUDRILLARD, Jean. O Sistema dos objetos. São Paulo: Perspectiva, 2008 [1968].

Comunicação, 2010 [1970].

A Sociedade de Consumo. Lisboa: Arte e Esquecer Foucault. Rio de Janeiro: Rocco, 1984. 
Simulacros e Simulação. Lisboa: Relógio D’água,

1991. Da sedução. Campinas: Papirus, 1992. Significação da publicidade. IN: Costa Lima, Luiz (org.). Teoria da cultura de massa. Rio de Janeiro: Paz e Terra, 2002.

BECKER, Beatriz \& TEIXEIRA, Juliana. Narrativas jornalísticas audiovisuais: um estudo dos efeitos da convergência no JN e no UOL. Revista Galáxia, São Paulo, № 18, p. 232-246, dez. 2009.

BECKER, Howard. Uma teoria da ação coletiva. Rio de Janeiro: Zahar Editores, 1977. . Mundos artísticos e tipos sociais. IN: Velho, Gilberto (org.). Arte e Sociedade. Rio de Janeiro: Zahar editores, 1977a. Doing Things Together. Evanston, Illinois: Northwestern University Press, 1986. Métodos de Pesquisa em Ciências Sociais. São Paulo: Editora Hucitec, 1993.

A Escola de Chicago. Mana: Estudos de Antropologia Social, v. 2, p. 177-188, 1996.

New Directions in the Sociology of Art. Trabalho apresentado no colóquio da European Sociological Association. Paris, abril de 2003.2 Disponível em: <http://howardsbecker.com/articles/newdirections.html>.

. Outsiders: estudos de sociologia do desvio. Rio de Janeiro: Zahar, 2008 [1963].

Uma carreira como sociólogo da música. Contemporânea. Revista de Sociologia da UFSCar. São Carlos, v. 3, no 1, jan./jun. 2013, p. 131-141, 2013.

BERGER, Peter \& LUCKMANN, Thomas. A construção social da realidade. Petrópolis: Vozes, 2002 [1966].

BERNBACH, William; et al. The art of weiting advertising: conversations with Masters of the Craft. Illinois: Mc-Graw Hill, 2003.

BLUMER, Herbert. Sociological implications of the thought of George Herbert Mead. IN: American Journal of Sociology. v.71. p. 535-544, 1966.

BOJUNGA, Claudio. JK, o artista do impossível. Rio de Janeiro: Objetiva, 2001.

BONADIO, Maria Claudia. Moda e sociabilidade: mulheres e consumo na São Paulo dos anos 1920. São Paulo: Editora Senac São Paulo, 2007.

BOORSTIN, Daniel J. The image: A guide to pseudo-events in America. New York: Atheneum, 1980.

BORTONI-RICARDO, Stella Maris et al. Raízes sociolinguísticas do analfabetismo no Brasil. Revista ACOALFAplp: Acolhendo a alfabetização 
nos países de língua portuguesa, São Paulo, ano 2, nำ 4, 2008. Disponível em: <www.acoalfaplp.org>.

BOUCHER, François. História do vestuário no ocidente. São Paulo: Cosac Naif, 2010.

BOURDIEU, Pierre. O campo científico. IN: Ortiz, R. (org.). Pierre Bourdieu. São Paulo: Ática, 1983 [1976].

A distinção: crítica social do julgamento. São Paulo: Zouk: EDUSP, 2007 [1979].

O senso prático. Petrópolis: Vozes, 2009 [1980].

Brasil, 1998 [1989]. O poder simbólico. Rio de Janeiro: Bertrand Campinas: Papirus, 1994.

Razões práticas: sobre a teoria da ação.

BOXER, Charles. O império marítimo português - 1415-1825. São Paulo: Companhia das Letras, 2002.

BRAGA, Adriana \& LOGAN, Robert K. Usos sociais do telefone celular nas ruas do Rio de Janeiro. IN: Antônio Fausto Neto et al. (Orgs.). A Rua no século XXI: materialidade urbana e virtualidade cibernética. Maceió: EDUFAL, 2014.

BROWN, Archie. Seven years that changed the world: perestroika in perspective. Oxford: University Press, 2007.

BUCCI, Eugênio. Brasil em tempo de TV. São Paulo: Boitempo, 1997.

BURKE, Peter. O que é História Cultural? Rio de Janeiro: Jorge Zahar, 2005.

CADENA, Nelson Verón. Brasil - 100 anos de propaganda. São Paulo: Referência, 2001.

CAMPBELL, Colin. A ética romântica e o espírito do consumismo moderno. Rio de Janeiro: Rocco, 1987.

CANCLINI, Nestor Garcia. Teorias da interculturalidade e fracassos políticos. IN: Diferentes, desiguais e desconectados. Rio de Janeiro: Editora UFRJ, 2005.

CARDOSO, Athos Eichler. A origem das séries de aventura e mistério da radiofonia brasileira e sua interação como história em quadrinhos - 19401959. In: XXI Congresso Brasileiro de Ciências da Comunicação, 1998. Disponível em: $<$ http://www.portcom.intercom.org.br/navegacaoDetalhe.php?option=traba lho\&id=45519> 
CARDOSO, Miriam Limoeiro. Ideologia do desenvolvimento - Brasil: JKJQ. Rio de Janeiro: Paz e Terra, 1978.

CARRASCOZA, J.L.A. \& HOFF, T. Ecos da literatura na publicidade brasileira nas primeiras décadas do século XX. IN: CASTRO, Gisela Grangeiro da Silva \& BACCEGA, Maria Aparecida. (Orgs.). Comunicação e consumo nas culturas locais e global. São Paulo: ESPM, 2009.

Narrativa publicitária: modernização e consumo no Brasil dos anos 1950. Primeiro movimento. Anais do II Pró-Pesq PP - Encontro nacional de pesquisadores em publicidade e propaganda. São Paulo: ABP2, 2011a.

Modernização no Brasil dos anos 1950:

os não ditos nos auto-anúncios de agências de propaganda. Anais do XXXIV Congresso Brasileiro de Ciências da Comunicação. Recife: Intercom, 2011b.

Ditos e não ditos: O Brasil e as práticas de consumo nos auto-anúncios das agências de publicidade nos anos 1950. Revista Organicom. São Paulo: ECA-USP. Ano 12. ㄲo 22. 1ำ semestre 2015.

CARVALHO, Maria Paula Schmidt. Caravanas da Identidade: Um estudo de recepção sobre as representações feitas pela Caravana JN - por dentro da maior reportagem do Brasil e perto dos brasileiros. Dissertação de mestrado. PUC-Rio, 2008.

CASTELLS, Manuel. A Sociedade em Rede. A era da informação: economia, sociedade e cultura. Volume 1. São Paulo: Paz e Terra, 1999. . A Galáxia da Internet. Rio de Janeiro: Zahar, 2004.

CASTELO BRANCO, R.; MARTENSEN, R.L. \& REIS, F. (Orgs.) História da Propaganda no Brasil. São Paulo: T.A. Queiroz, 1990.

CASTRO, Ruy. Roquette-Pinto: o homem multidão. Disponível em: $<$ http://www.soarmec.com.br/roquette4.html >. Costa, Maria Luisa Furlan. Rádio Educativo: a contribuição de Edgar Roquette-Pinto para a democratização do conhecimento no Brasil. UEM. Acessado em junho de 2014.

CERTEAU, Michel de. A escrita da história. Rio de Janeiro: Forense Universitária, 1982.

CHARTIER, Roger. A história cultural entre práticas e representações. Lisboa: DIFEL, 1990.

CHAUÍ, Marilena. Simulacro e Poder: uma análise da Mídia. São Paulo: Perseu Abramo, 2006.

CIVITA, Roberto. As revistas. IN: CASTELO BRANCO, R.; MARTENSEN, R.L. \& REIS, F. (eds.). História da propaganda no Brasil. São Paulo: T.A. Queiroz, 1990. 
COHEN, Marilene. JK. São Paulo: Editora Globo, 2006.

COHN, Sergio \& PIMENTA, Heyk. Maio de 68. Rio de Janeiro: Azougue Editorial, 2008.

CONTI, Mário Sérgio. Notícias do Planalto: a imprensa e Fernando Collor. São Paulo: Companhia das Letras, 1999.

COSTA, Ricardo \& COSTA, Tailson Pires. Técnicas de persuasão na propaganda eleitoral. São Paulo: Fiúza Editores, 2004.

COUTO, José Geraldo. Brasil: anos 60. São Paulo: Editora Ática, 1999.

D'ALMEIDA, Armando. Depoimento em "Hall da Fama da Propaganda Brasileira", editado por Fernando Reis e Márcia Guedes. IN: Revista Propaganda, № 237, abril, 1976.

DAMANTE, Nara. Grandes nomes da mídia brasileira. São Paulo: Nobel, 2006.

DAMATTA. Roberto. Prefácio. IN: Rocha, E. Magia e Capitalismo. São Paulo: Brasiliense, 1985.

Prefácio. IN: ROCHA, E. A sociedade do sonho: comunicação, cultura e consumo. Rio de Janeiro: Mauad, 1995.

Apresentação. IN: VAN GENNEP, Arnold. Os ritos de passagem. Petrópolis: Vozes, 2011.

DEBORD, Guy. A sociedade do espetáculo. Rio de Janeiro: Contraponto, 1997 [1967].

DINIZ, José Alencar. A recriação dos gêneros eletrônicos analógicodigitais: radionovela, telenovela e webnovela. Tese de doutorado - PUCRS. Porto Alegre, 2009.

DOMINGUES, Caio. Elementos de propaganda. Rio de Janeiro: Edições PN, 1959.

DOSSE, François. História do estruturalismo. Bauru, SP: Edusc, 2007.

DOUGLAS, M. \& ISHERWOOD, B. O mundo dos bens. Rio de Janeiro: Ed.UFRJ, 2004 [1979].

DRIVER, Stephanie Schwartz. A declaração de independência dos Estados Unidos. Rio de Janeiro: Jorge Zahar Ed., 2006.

DUALIBI, Roberto \& SIMONSEN JR., Harry. Criatividade e marketing. São Paulo: McGraw-Hill do Brasil, 1990.

Campus, 2005. Cartas a um jovem publicitário. São Paulo: Editora 
DUARTE, Jorge; BARROS, Antonio \& NOVELLI, Ana Lucia Romero. Métodos e técnicas de pesquisa em comunicação. São Paulo: Atlas, 2006.

ECO, Umberto. Apocalípticos e integrados. São Paulo: Perspectiva, 1976. Viagem na irrealidade cotidiana. Rio de Janeiro: Nova

Fronteira, 1984.

ESCOSTEGUY, Ana Carolina D. Cartografias dos estudos culturais Uma versão latino-americana - ed. on-line - Belo Horizonte: Autêntica, 2010.

FAOUR, Rodrigo. Revista do Rádio. Rio de Janeiro: Relume Dumará, 2002.

FELIZARDO, José Joaquim. A legalidade: último levante gaúcho. Porto Alegre: UFRGS, 2003.

FERRARETTO, Luiz Arthur. Rádio - Veículo, História e a Técnica. Porto Alegre: Doravante, 2007.

FICO, Carlos. Reinventando o otimismo: ditadura, propaganda e imaginário social no Brasil. Rio de Janeiro: FGV, 1997.

FIGUEIREDO, Anna Cristina Camargo Moraes. Liberdade é uma calça velha, azul e desbotada: publicidade, cultura de consumo e comportamento político no Brasil, 1954-1964. São Paulo: Hucitec, 1998.

FOUCAULT, Michel. Vigiar e punir. Petrópolis: Vozes, 2007 [1975]. História da loucura na idade clássica. São Paulo:

Perspectiva, 2005 [1961].

FREIRE FILHO, João. Mídia, consumo cultural e estilo de vida na pósmodernidade. ECO-PÓS, v.6, no 1, p. 72-97, 2003.

Como ser uma adolescente liberada no novo milênio. IN: Reinvenções da resistência juvenil: os estudos culturais e as micropolíticas do cotidiano, p. 111-162. Rio de Janeiro: Mauad, 2007.

(org.). Ser Feliz Hoje: reflexões sobre o imperativo de felicidade. Rio de Janeiro: FGV, 2010.

Sonhos de grandeza: o gerenciamento da

vida em busca da alta performance. In: FREIRE FILHO, João \& COELHO, Maria das Graças Pinto. (orgs.). A promoção do capital humano: mídia, subjetividade e o novo espírito do capitalismo, p. 27-50. Porto Alegre: Sulina, 2011.

Big Brother e o valor da autenticidade. IN: FRANÇA, Vera \& CORRÊA, Laura. (orgs.). Mídia, instituições e valores, p. 53-66. Belo Horizonte: Autêntica, 2012.

\& COELHO, Maria das Graças Pinto. (orgs.) Jornalismo, cultura e sociedade: visões do Brasil contemporâneo. Porto Alegre: Sulina, 2014. 
FREITAS, Ricardo. Rio de Janeiro, lugar de eventos: das exposições do início do século $X X$ aos megaeventos contemporâneos. Trabalho apresentado no Grupo de Trabalho "Comunicação em contextos organizacionais" do XX Encontro da Compós. Porto Alegre, 2011.

FREYRE, Gilberto. Sobrados e mucambos: decadência do patriarcado rural e desenvolvimento do urbano. São Paulo: J. Olympio, 2003 [1936]. . Os escravos nos anúncios de jornais brasileiros do século XIX. São Paulo: Global, 2010 [1961].

FURTADO, Celso. A economia latino-americana: formação histórica e problemas contemporâneos. São Paulo: Companhia das Letras, 2007.

GABLER, Neal. Vida, o filme. São Paulo: Companhia das Letras, 1999.

GABRIEL, Martha. Marketing na era digital. São Paulo: Novatec, 2010.

GASPARI, Elio. A ditadura envergonhada. Rio de Janeiro: Intrínseca, 2014a.

2014b.

A ditadura escancarada. Rio de Janeiro: Intrínseca, A ditadura derrotada. Rio de Janeiro: Intrínseca, 2014c.

$2014 d$. A ditadura encurralada. Rio de Janeiro: Intrínseca,

GEERTZ, Clifford. A interpretação das culturas. Rio de Janeiro: LTC. 1989 [1973].

GIAMBIAGI, Fabio; BARROS DE CASTRO, Lavínia; VILLELA, André \& HERMANN, Jennifer. Economia Brasileira Contemporânea. São Paulo: Elsevier/Campus, 2011.

GIDDENS, Anthony. Modernidade e Identidade. Rio de Janeiro: Jorge Zahar Editor, 2002.

GOFFMAN, Erving. A representação do eu na vida cotidiana. Petrópolis: Vozes, 1983 [1959].

deteriorada. Rio de Janeiro: Zahar, 1975 [1963].

Estigma: notas sobre a manipulação da identidade Gender advertisements. New York: Harper and Row, 1979.

GOMES, José Jairo. Direito eleitoral. São Paulo: Atlas, 2010.

GONÇALVES, José Esmeraldo \& BARROS, J.A. (orgs.). Aconteceu na Manchete: as histórias que ninguém contou. Rio de Janeiro: Desiderata. 2008.

GOULART, Ana Paula. Imprensa e história no Rio de Janeiro dos anos 50. Rio de Janeiro: E-papers, 2006. 
GRACIOSO, Francisco. Marketing. Uma experiência brasileira. São Paulo: Cultrix, 1971.

\& WHITAKER PENTEADO, José Roberto. Cinquenta anos de vida e propaganda brasileiras. Escola Superior de Propaganda e Marketing. São Paulo: Mauro Ivan Marketing editorial, 2001.

GRIMAL, Pierre. A civilização romana. Lisboa: Edições 70, 2001.

GROPPO, Luís Antonio. Juventude: ensaios sobre sociologia e história das juventudes modernas. Rio de Janeiro: Difel, 2000.

HALL, Stuart. A Identidade Cultural na Pós-modernidade. Rio de Janeiro: DP\&A, 2004.

. The Work of Representation, IN: HALL, S. (ed.) Representation: Cultural Representations and Signifying Practices. Londres: Sage, 2011.

HARPER, John Lamberton. The Cold War. Oxford: Oxford University Press, 2011.

HAYASHI, Ryoichi. The Silk Road and the Shoso-in. New York/Tokyo: Weatherhill/Heibonsha, 1975.

HOBSBAWM, Eric. Era dos extremos - o breve século XX: 1914-1991. São Paulo: Companhia das Letras, 1994.

HOLLANDA, Heloisa Buarque \& GONÇALVES, Marcos Augusto. Cultura e participação nos anos 60. São Paulo: Brasiliense, 1982.

HOPKINS, Claude. A ciência da propaganda. São Paulo: Cultrix, 1973.

HOWER, Ralph M. The history of an advertising agency: N. W. Ayer \& Sons at Work, 1869-1949. Cambridge: Harvard University Press, 1978.

HUNT, Lynn. A nova história cultural. São Paulo: Martins, 2001.

IRIBURE, André. MPM Propaganda: a história da agência dos anos de ouro da publicidade brasileira. 2002. Dissertação de Mestrado. Orientadora: Nilda Jacks. Cap. Primórdios.

\& Jacks, Nilda. MPM: a agência dos anos de ouro da publicidade brasileira. Florianópolis: Editora Insular, 2015.

JACKS, Nilda. A publicidade vista pela academia: tendências dos anos 90. In: RAMOS, Roberto (org.). Mídia, textos e contextos, p. 205-219. Porto Alegre: PUC-RS, 2001.

; PIEDRAS, Elisa. A contribuição dos estudos culturais para a abordagem da publicidade: processos de comunicação persuasiva e as noções de articulação e fluxo. E-Compós, v. 6, 2006. 
; PIEDRAS, Elisa; KNEWITZ, Anna Paula \& MALDANER, Nilse Maria. A publicidade vista entre 2000 e 2005: pesquisas com foco na recepção. ECO-PÓS, v. 13, p. 14-28, 2010.

JACOB, Cesar Romero; HEES, Dora; WANIEZ, Philippe \& BRUSTLEIN, Violette. A geografia do voto nas eleições presidenciais do Brasil: 19892006. Rio de Janeiro/Petrópolis PUC-Rio/Vozes, 2010.

JENKINS, Henry. Cultura da convergência. São Paulo: Aleph, 2008.

JENSEN, K.B. \& JANKOWSKI, N.W. (eds.). A handbook of qualitative methodologies for mass communication research. Londres/Nova lorque: Routledge, 1991.

KANNER, Berenice. The 100 Best TV Commercials and Why they Worked. Crown, 2000.

KELLNER, Douglas. A cultura da mídia. Bauru: EDUSC, 2001.

KLÖCKNER, Luciano. O Repórter Esso: a síntese radiofônica mundial que fez história. Porto Alegre: Age, 2008.

KNOPLOCH, Zilda. Ideologia do publicitário. Rio de Janeiro: Achiamé, 1980.

KOSHIBA, L. \& PEREIRA, Denise M.F. História do Brasil. São Paulo: Atual, 1996.

LAMOUNIER, Bolívar \& FIGUEIREDO, Rubens (orgs.). A era FHC: um balanço. São Paulo: Cultura Editores Associados, 2002.

LAPPOLI, Mariana. Publicidade na era digital. Florianópolis: Pandion, 2008.

LATOUR, Bruno. Fifth Source of Uncertainty: Writing Down Risky Accounts. IN: Reassembling the Social - An Introduction to Actor-Network Theory. Oxford: University Press, 2007.

LATTMAN-WELTMAN, Fernando; RAMOS, Plínio de Abreu \& CARNEIRO, José Alceu Dias. A imprensa faz e desfaz um presidente. Rio de Janeiro: Nova Fronteira, 1994.

LAZARATTO, Maurízio. As revoluções do capitalismo. Rio de Janeiro: Civilização Brasileira, 2006.

LE GOFF, Jacques. A Idade Média e o dinheiro: ensaio de antropologia histórica. Rio de Janeiro: Civilização Brasileira, 2014.

LEARS, T.J. Jackson. Fables of abundance: a cultural history of advertising in America. Nova lorque: Basic Books, 1994. 
LEITE, Manuel. Rádio, "uma voz que vai de um fim a outro fim do mundo". IN: CASTELO BRANCO, R.; MARTENSEN, R. L. \& REIS, F. (eds.). História da propaganda no Brasil. São Paulo: T.A. Queiroz, 1990.

LEITE, Yákara Vasconcelos Pereira; PEREIRA, Sávio Delano Vasconcelos \& ALMEIDA LEITE, Rodrigo de. Louis Vuitton: a Administração Estratégica no Mundo do Luxo. Trabalho apresentado no IV encontro de estudos em estratégia da ANPAD. Recife- PE, junho, $2009 . \quad$ Disponível em: <http://www.anpad.org.br/diversos/trabalhos/3Es/3es_2009/2009_3ES85. pdf $>$.

LÉVI-STRAUSS, Claude. Raça e história. Lisboa: Presença, 1973 [1952]. [1962]. . Totemismo hoje. Petrópolis: Vozes, 1975 Editora Nacional, 2012 [1962]. O pensamento selvagem. São Paulo: Cia.

LIMA, Luiz Costa. Teoria da Cultura de Massa. São Paulo: Paz e Terra, 2002.

LIPOVETSKY, Gilles. A felicidade paradoxal. Ensaio sobre a Sociedade de Hiperconsumo. São Paulo: Cia. das Letras, 2007.

LONGERICH, Peter. Joseph Goebbels: uma biografia. Rio de Janeiro: Objetiva, 2014.

LOPES, Maria Immacolata Vassallo de \& GÓMEZ, Guillermo Orozco. Relações de gênero na Ficção Televisiva: anuário OBITEL 2015. Porto Alegre: Sulina, 2015.

. Convergências e transmidiação da ficção televisiva. OBITEL 2010. São Paulo: Editora Globo, 2010.

LORÊDO, João. Era uma vez... a televisão. São Paulo: Alegro, 2000.

LUPETTI, Marcélia. Administração em Publicidade: a verdadeira alma do negócio. Rio de Janeiro: Cengage, 2009.

LUPORINI, M. P. \& CARRASCO, C. R. . O Cinejornal no Brasil: estudo de suas motivações temáticas. V Seminário Memória Ciência e Arte. v. 1. p. 10-15. Campinas, 2007. Disponível em: <http://www.preac.unicamp.br/memoria/textos/Marcos\%20Patrizzi\%20Lup orini\%20-\%20completo.pdf>.

MACDONALD, Ian. The People's Music. Reino Unido: Pimlico Books, 2003. 
MACHADO, Arlindo. A invenção da televisão brasileira. IN: FREIRE FILHO, João \& BORGES, Gabriela (orgs.). Estudos de televisão. Diálogos Brasil-Portugal. Porto Alegre: Sulina, 2011.

MALANGA, Eugênio. Publicidade: uma introdução. São Paulo: Atlas, 1976.

MARANHÃO FILHO, Luiz. No tempo do reclame. Recife: Editora Universitária, UFPE, 2002.

MARCHAND, Roland. Advertising the American dream. Making way for modernity, 1920-1940. Berkeley: University of California Press, 1985.

MARCONDES, Danilo. Iniciação à história da filosofia: dos pré-socrátivos a Wittgenstein. Rio de Janeiro: Zahar, 2002.

MARCONDES, Pyr. Uma história da propaganda brasileira. Melhores campanhas, grandes gênios da criação, personagens inesquecíveis. Rio de Janeiro: Ediouro, 2001.

MARTENSEN, Rodolfo Lima. O ensino da propaganda no Brasil. IN: CASTELO BRANCO, R.; MARTENSEN, R. L. \& REIS, F. (eds.). História da propaganda no Brasil. São Paulo: T.A. Queiroz, 1990.

Uma escola de devoção. In: GRACIOSO, F. \& PENTEADO, J. 50 anos de vida e propaganda brasileiras. São Paulo: Mauro Ivan Marketing, 2001.

MARTINS FILHO, Ives Gandra. História do Brasil. São Paulo: LTr, 2011.

MARX, Karl. O manifesto comunista. $2^{\text {a }}$ ed. Rio de Janeiro: Zahar, 1978 [1948].

.O capital: crítica da economia política. Livro 1 , volume $1,5^{\text {a }}$ ed. Rio de Janeiro: Civilização Brasileira, 1980 [1867].

MATTELART, Armand e Michele. História das teorias da comunicação. São Paulo: Edições Loyola, 1995.

MAUSS, Marcel. Ensaio sobre a dádiva. IN: MAUSS, Marcel. Sociologia e antropologia. São Paulo: Cosac \& Naify, 2003 [1925].

MAYER, Martin. Madison Avenue, U.S.A: the extraordinary business of advertising and the people who run it. Lincolnwood (Illinois): NTC, 1986.

MAZETTI, Henrique. As marcas da felicidade: transformações do bem viver na publicidade brasileira (1960-2010). Tese de doutorado. UFRJ, 2014.

MCCANN ERICKSON. McCann-Erickson publicidade. Técnica e prática de propaganda. Rio de Janeiro: Fundo de Cultura, 1962. 
MCCRACKEN, Grant. Cultura e consumo: novas abordagens ao caráter simbólico dos bens e das atividades de consumo. Rio de Janeiro: Mauad, 2003.

MCKENDRIK, Neil; BREWER, John \& PLUMB, J. H. The birth of consumer society. London: Europa Publications Limited, 1982.

MCLUHAN, Marshall. The Mechanical Bride: folklore of industrial man. Boston: Beacon Press, 1967 [1951].

Os meios de comunicação como extensões do

homem. São Paulo: Cultrix, 2007 [1964].

MEIO E MENSAGEM. As maiores campanhas do século. IN: Um século de propaganda, edição especial. São Paulo: Editora Meio e Mensagem, 1999.

MEMÓRIA GLOBO. Jornal Nacional: a notícia faz história. Rio de Janeiro: Jorge Zahar Editor, 2005.

MESSEDER PEREIRA, Carlos Alberto. O que é contracultura. São Paulo: Editora Brasiliense, 1992.

MILLER, Daniel. Material culture and mass consumption. Oxford: Blackwell, 1987. . Teoria das compras. São Paulo: Nobel, 2002.

MILLER, M. B. The Bon Marché. New Jersey: Princeton University Press, 1981.

MONTEIRO, Denilson. Chacrinha, a biografia. Rio de Janeiro: Casa da Palavra, 2014a.

MONTEIRO, Marcelo. U-93: A entrada do Brasil na Primeira Guerra Mundial. Porto Alegre: Besouro Box, 2014b.

MORAIS, Fernando. Chatô: o Rei do Brasil, a vida de Assis Chateaubriand. São Paulo: Companhia das Letras, 1994.

Na toca dos leões: a história da W/Brasil, uma das agências de propaganda mais premiadas do mundo. São Paulo: Editora Planeta, 2005.

MORIN, Edgar. Cultura de Massas no Século XX. Vol. 1: Neurose. O Espírito do Tempo. Rio de Janeiro: Forense Universitária, 1989 [1962].

MOSCOVICl, Serge. Representações sociais: investigações em psicologia social. Petrópolis: Vozes, 2011.

MOTA ROCHA, Maria Eduarda da. A nova retórica do capital: a publicidade brasileira em tempos neoliberais. São Paulo: Edusp, 2010. 
MUGGIATI, Roberto. História do Rock. São Paulo: Editora Três, 1983.

NAVARRO, Vinicius. Os sentidos da convergência: Entrevista com Henry Jenkins. Revista Contracampo. UFF. Niterói. oㅡ 21. Agosto, 2010.

NEVES, Eduardo Marcos. Vendedor de sonhos: a vida e a obra de Roberto Medina. São Paulo: Melhoramentos, 2006.

OGILVY, David. Confissões de um publicitário. São Paulo: Bertrand Brasil, 1993.

OLIVEIRA, Hebe Maria Gonçalves de. Muda Brasil: o marketing político que levou Tancredo Neves à presidência da República. Universidade Metodista de São Paulo - São Bernardo do Campo. Intercom, XXVI Congresso Anual em Ciência da Comunicação, Belo Horizonte/MG, 02 a 06 de setembro de 2003.

OLIVEIRA SOBRINHO, José Bonifácio. O livro do Boni. Rio de Janeiro: Casa da Palavra, 2011.

ORTIZ, Renato. Cultura brasileira e identidade nacional. São Paulo: Brasiliense, 1985.

. A moderna tradição brasileira. São Paulo: Brasiliense, 1988. . Mundialização e cultura. São Paulo: Brasiliense, 2003.

PAIS, José Machado. Dolências e Indolências da Vida Urbana. IN: LufaLufa Quotidiana. Ensaios sobre a cidade, cultura e vida urbana. Lisboa: ICS, 2010.

PALAZZO, Carmen Lícia. A cultura material na rota da seda: fontes para pesquisa em história medieval. Universidade Federal do Rio Grande do Sul. Revista Aedos, Revista do Corpo Discente do Programa de PósGraduação em História da UFRGS. v. 2, no 2, 2009.

PARK, Robert. Race and culture. Nova York: Free Pass, 1950.

York: Free Pass, 1952. Human Communities: the city and human ecology. Nova . Societies. Glencoe III: The Free Press, 1955.

PENTEADO, Claudia. J.W.Thompson Co.: 75 anos de Brasil. Revista ESPM-SP, set./out., 2004.

PERISCINOTO, Alex. Mais vale o que se aprende que o que te ensinam. São Paulo: Ed. Best Seller/Ed. Círculo do Livro, 1998.

PETIT, Francesc. Faça você uma marca. São Paulo: Editora Futura, 2007. Propaganda llimitada. São Paulo: Editora Futura, 2006. 
PIEDRAS, Elisa \& JACKS, Nilda. A publicidade e o mundo social. Uma articulação pela ótica dos estudos culturais. Contemporânea, v.3, no 2, p. 197-216, 2005.

PINCAS, Stéphane \& LOISEAU, Marc. A History of Advertising. Ed. Taschen, 2008.

POLANYI, K. A grande transformação: as origens da nossa época. São Paulo: Elsevier-Campus, 2012 [1944].

PRADO, Magaly. História do rádio no Brasil. São Paulo: Da Boa Prosa, 2012.

PRADO JUNIOR, Caio. História Econômica do Brasil. São Paulo: Brasiliense, 1977.

Companhia das Letras, 2011.

Formação do Brasil contemporâneo. São Paulo:

QUEIROZ, Adolpho (org.). Propaganda, história e modernidade. Piracicaba: Ed. Degaspari, 2005.

RABELO, Genival. Os tempos heroicos da propaganda. Rio de Janeiro: Empresa Jornalística PN S/A, 1956.

RAMOS, Ricardo. Do reclame à comunicação: pequena história da propaganda no Brasil. São Paulo: Anuário Brasileiro de Propaganda 701/Publinform, 1985 [1970]. Propaganda. São Paulo: Global, 1987.

1500-1930. Vídeo-clipe das nossas raízes. IN: CASTELO BRANCO, R.; MARTENSEN, R. L. \& REIS, F. (eds). História da propaganda no Brasil. São Paulo: T.A. Queiroz, 1990.

\& MARCONDES, Pyr. 200 anos de propaganda no

Brasil: do reclame ao cyber-anúncio. São Paulo: Meio e Mensagem, 1995.

RAPPAPORT, E. Uma nova era de compras: a promoção do prazer feminino no West End Iondrino, 1909-1914. IN: CHARNEY, L. \& SCHWARTZ, V. (orgs.). O cinema e a invenção da vida moderna. São Paulo: Cosac \& Naify. p. 187-221, 2001.

REBOUÇAS, Marilda de Vasconcellos. Surrealismo. São Paulo: Ática, 1986.

REIS, Fernando. São Paulo e Rio: a longa caminhada. IN: CASTELO BRANCO, R.; MARTENSEN, R. \& Reis, F. (orgs.) História da Propaganda no Brasil. São Paulo: T.A. Queiroz, 1990.

RENHA, João. David Ogilvy: A origem da publicidade moderna. Rio de Janeiro: Ed. PUC-Rio, 2011. A propaganda depois de Washington Olivetto. Rio de Janeiro: Ed. PUC-Rio: Ed. Leya, 2013. 
ROCHA, Everardo. Magia e Capitalismo: um estudo antropológico da publicidade. São Paulo: Brasiliense, 1985.

A sociedade do sonho: comunicação, cultura e consumo. Rio de Janeiro: Mauad, 1995.

Cultura Brasileira. Reflexões, análises e

perspectivas. Rio de Janeiro: Desiderata, 2007.

\& AMARAL, Maria. Consumo e entretenimento: a loja

de departamentos como espaço de sociabilidade (1830-1930). Revista Comunicação, mídia e consumo. São Paulo, v.6, no 17, p. 143-160, nov. 2009.

\& PEREIRA, Claudia. Juventude e Consumo: um estudo sobre a comunicação na cultura contemporânea. Rio de Janeiro: Mauad X, 2009.

\& PEREIRA, Claudia (orgs.). Cultura e imaginação publicitária. Rio de Janeiro: Ed. PUC-Rio/Mauad X, 2013.

; PEREIRA, Claudia \& AUCAR, Bruna. Os anúncios nas revistas ilustradas: imaginário e valores brasileiros no início do século XX. IN: Cultura e imaginação publicitária. Rio de Janeiro: Ed. PUCRio/Mauad X, 2013a.

PEREIRA, Claudia \& BOESCHENSTEIN, Livia. Templos e shoppings: a sacralização do consumo na contemporaneidade. IN: Cultura e imaginação publicitária. Rio de Janeiro: Ed. PUC-Rio/Mauad $\mathrm{X}, 2013 \mathrm{~b}$.

; PEREIRA, Claudia \& BARROS, Carla (orgs.). Cultura e experiência midiática. Rio de Janeiro: Ed. PUC-Rio/Mauad X, 2014.

; FRID, Marina \& CORBO, William. O Paraíso do Consumo: Émile Zola, a magia e os grandes magazines. No prelo, 2016.

RODRIGUES, José Carlos. Comunicação e Significado. Rio de Janeiro: Ed. PUC-Rio/Mauad X, 2006.

ROSA, Mário. A Reputação na velocidade do pensamento: Imagem e ética na era digital. São Paulo: Geração Editorial, 2008.

ROSSINI, Antoninho P. Propaganda \& Marketing. Encarte de A Gazeta Esportiva. São Paulo, 1984.

SAHLINS, Marshall. Cultura e razão prática. Rio de Janeiro: Zahar, 1979.

SÁNCHEZ, M. R, et al. Bases Psicológicas de la Creatividad. IN: Creatividad Aplicada una Apuesta de Futuro, (Tomo I). Universidad Autónoma de Madrid. Madrid: Editorial Dikinson. S.L., 2003.

SANT'ANNA, Armando; ROCHA JUNIOR, Ismael \& GARCIA, Luis Fernando Dabul. Propaganda: teoria, técnica e prática. Rio de Janeiro: Cengage, 2009.

SANT'ANNA, Armando. Propaganda: teoria, técnica e prática. Rio de Janeiro: Cengage, 1973. 
SAUSSURE, Ferdinand de; BALLY, Charles \& SECHEHAYE, Albert; RIEDLINGER. Curso de linguística geral. São Paulo: Cultrix, 2006 [1916].

SAVAGE, Jon. A criação da juventude: como o conceito de teenage revolucionou o século XX. Rio de Janeiro: Rocco, 2009.

SCHERER, Marta. Imprensa e Belle Époque: Olavo Bilac, o jornalismo e suas histórias. Palhoça: Ed. Unisul, 2012.

SENNET, Richard. O Artífice. Rio de Janeiro: Record, 2009.

SICILIANO, Tatiana Oliveira. O Rio de Janeiro de Artur Azevedo: cenas de um teatro urbano. Rio de Janeiro: Faperj: Mauad, 2014.

SILVA, Janice Theodoro da. Descobrimentos e Colonização. São Paulo: Ed. Ática, 1989.

SIMMEL, Georg. The persistence of social groups. In: American Journal of Sociology, Volume 3, Issue 5, p. 662-698. Chicago: The University of Chicago Press. 2002 [1898].

Grafia, 2008 [1905].

Filosofia da moda e outros escritos. Lisboa: Texto \&

SODRÉ, Muniz. O monopólio da fala - função e linguagem da televisão no Brasil. Petrópolis: Vozes, 1984.

\& FERRARI, Maria Helena. Técnica de reportagem: notas sobre a narrativa jornalística. São Paulo: Summus, 1986.

Comunicação: um campo em apuros teóricos. Revista

Matrizes. USP. Ano 5- no 2- jan./jun. 2012. p. 11-27. São Paulo. Disponível em: <http://www.matrizes.usp.br/index.php/matrizes/article/viewFile/336/pdf>.

SODRÉ, Nelson Werneck. História da imprensa no Brasil. Rio de Janeiro: Mauad, 1999.

SOUZA, Karen. Ridendo Castigat Mores: a Semana Illustrada de Henrique Fleiuss e a formação da imprensa ilustrada no Brasil. Rio de Janeiro 1860-1876. Anais do XVII Encontro Regional de História - O lugar da História. ANPUH/SPUNICAMP. Campinas, setembro de 2004.

TAMILIA, R. The wonderful world of the department store in historical perspective: a comprehensive international. University of Quebec, 2002. Disponível em: <http://faculty. quinnipiac.edu/charm/dept.store.pdf>.

TERRA, Renato \& CALIL, Ricardo. Uma noite em 67: entrevistas completas com os artistas que marcaram a era dos festivais. São Paulo: Editora Planeta, 2013. 
THOMPSON, John B. A mídia e a modernidade: uma teoria social da mídia. Petrópolis: Vozes, 2002.

TOALDO, Mariângela Machado. Cenário publicitário brasileiro: anúncios e moralidade contemporânea. Porto Alegre: Sulina, 2005.

TRINDADE, Eneus \& PEREZ, Clotilde. Os rituais de consumo como dispositivos midiáticos para a construção de vínculos entre marcas e consumidores. ALCEU: Revista de Comunicação, Cultura e Política. v.15, no 29, jul./dez. 2014. Rio de Janeiro: PUC-Rio, Dep. Comunicação Social.

VEBLEN, Thorstein. A teoria da classe ociosa. São Paulo: Pioneira, 1965 [1899].

VELHO, Gilberto (org.). A Utopia Urbana: Um Estudo de Antropologia Social. Rio de Janeiro: Zahar, 1973.

Rio de Janeiro: Zahar, 1974.

Desvio e Divergência: uma crítica da patologia social.

Uma entrevista com Howard S. Becker. Estudos históricos. Rio de Janeiro, v. 3, no 5, p. 114-136,1990.

VELLOSO, João Paulo dos Reis \& MARTINS, Luciano. A nova ordem internacional e a terceira revolução industrial. Rio de Janeiro: José Olympio, 1992.

VELLOSO, Mônica. Sensibilidades modernas: as revistas literárias e de humor na Primeira República. IN: LUSTOSA, Isabel. (org.). Imprensa, História e literatura. Rio de Janeiro: FCRB: 2008.

2010. História e modernismo. Belo Horizonte: Autêntica,

VIEIRA, Stalimir. Raciocínio criativo na publicidade. São Paulo: Martins Fontes, 2000.

VILLA, Marco Antônio. Jango, um perfil, 1945-1964. São Paulo: Ed. Globo, 2004.

WAGNER, Roy. A invenção da cultura. São Paulo: Cosac Naify, 2010 [1975].

WEBER, Max. Ética protestante e o espírito do capitalismo. São Paulo: Liv. Pioneira Ed., 1985 [1904].

WHITAKER PENTEADO. José Roberto. A propaganda antiga. São Paulo: Livraria Pioneira Editora, 1974.

WILLIAMS, Raymond. Cultura e materialismo. São Paulo: Editora Unesp, 2011 [1980]. 
WILLIAMS, Rosalind. Dream Worlds: Mass Consumption in Late Nineteenth Century France. Los Angeles, California: University of California Press, 1982.

WOLTON, Dominique. Elogio do grande público: uma teoria crítica da televisão. São Paulo: Editora Ática, 2006.

ZARAGOZA, José. Zaragoza e amigos. Ideias premiadas. São Paulo: Zaragoza, 2014.

ZOZZOLI, Jean Charles Jacque. A pesquisa em publicidade e propaganda na INTERCOM. Anais do I Pró-Pesq PP - Encontro nacional de pesquisadores em publicidade e propaganda. São Paulo: Schoba, 2010. 


\section{Fontes de Pesquisa}

Acervo Digital O Globo: acervo.oglobo.globo.com

Acervo O Estado de S. Paulo: acervo.estadao.com.br

Advertising Age: www.adage.com

Almanaque da Comunicação: www.almanaquedacomunicacao.com.br

Anatel: www.anatel.gov.br

Anuários Associação Brasileira de Propaganda: www.abp.com.br/anuarios

Arquivos da ditadura: arquivosdaditadura.com.br

Associação Brasileira de Agências de Publicidade: www.abap.com.br / www.abap-mg.com.br

Associação Brasileira de Propaganda: www.abp.com.br / www.abap-mg.com.br

Clube de Criação: www.clubedecriacao.com.br

Centro de Pesquisa e Documentação de História Contemporânea do Brasil:

www.cpdoc.fgv.br

Design history: www.designhistory.org

Diálogos históricos: www.dialogoshistoricos.wordpress.com

Empresa Bayer: $\underline{w w w . b a y e r . c o m . b r}$

Festival de Cannes: $\underline{w w w . c a n n e s l i o n s . c o m}$ e www.canneslionsarchieve.com

Jornal Folha de S.Paulo: www.folha.uol.com.br

Jornal O Estado de S. Paulo / Blog Reclames do Estadão: www.estadao.com.br

Jornal O Globo: www.oglobo.com.br

Jornalistas.org: www.jornalistas.org.br

Grandes nomes da propaganda: www.grandesnomesdapropaganda.com.br

Grupo Abril: www.grupoabril.com.br

Grupo de Mídia: www.midiarj.org.br

Grupo Interpublic: www.interpublic.com

Guiness Book: www.guinessworldrecords.com

História Net: www.historianet.com.br

Howard Becker: www.howardbecker.com

IBGE: www.ibge.gov.br

Ibope: www.ibope.com.br

Instituto Brasileiro de Defesa do Consumidor: www.idec.org.br 
Instituto Nielsen: www.nielsen.com

Memória Jornal O Globo: www.memoria.oglobo.globo.com

Meio e Mensagem: www.meioemensagem.com.br

Memória Globo: www.memoriaglobo.com.br

Portal IG: www.ig.com.br

Portal dos Jornalistas: www.portaldosjornalistas.com.br

Portal da Legislação Governo Federal: www.planalto.gov.br

Portal da Propaganda: www.portaldapropaganda.com.br

Prêmio Clio Awards: www.clioawards.com

Profissionais do Ano: www.profissionaisdoano.redeglobo.com.br

Propaganda em revista: www.propagandaemrevista.com.br

Propagandas Históricas: www.propagandashistoricas.com.br

Propmark (jornal do mercado da comunicação publicado pela Editora Referência):

www.propmark.com.br

ऽ Rede Globo: www.redeglobo.globo.com

Rede Manchete: www.redemanchete.net

Revista Cult- www.revistacult.uol.com.br

Revista Época: www.revistaepoca.globo.com

Revista Exame: www.exame.abril.com.br

The Shangri-las Biography: www.theshangri-las.com/Biography.htm

SBT: www.sbt.com.br

Seriado Mad Men, produzido pelo canal AMC. EUA, 2007

Filme: Uma noite em 67. Brasil, 2010.

Filme: La Garçonne. França, 1923.

Agências:

ADAG Comunicação: www.adag.com.br

África: www.africa.com.br

Almap BBDO: www.almapbbdo.com.br

Artplan: www.artplan.com.br

BBDO Worldwide: www.bbdo.com

CPB: www.cpbgroup.com

DM9DDB: www.dm9ddb.com.br 
DPZ: www.dpzt.com.br

F/Nazca Saatchi \& Saatchi: $\underline{\text { www.fnazca.com.br }}$

Fallon: www.fallon.com

Foot, Cone \& Belding (FCB): www.fcb.com

Grey Advertising Global: www.grey.com

Grupo ABC de Comunicação e Marketing: www.grupoabc.com

JWT: www.jwt.com

Leo Burnett: www.leoburnett.com e www.leoburnett.com.br

Lew'Lara: www.lewlaratbwa.com.br

Lintas: www.mullenlowelintas.in

Loducca: www.loducca.com.br

McCann: www.mccann.com

Neogama: www.neogamabbh.com.br

Norton: www.nortonpublicidade.com.br

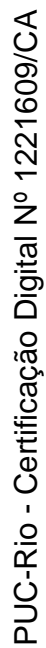

Ogilvy \& Mather: www.ogilvy.com

Pereira \& O’Dell: www.pereiraodell.com

Publicis Brasil: www.publicis.com.br

WMcCann: www.wmccann.com.br

Young \& Rubicam: www.yr.com e www.yrbrasil.com.br 